$$
\text { UNIVERSIDADE DE SÃO PAULO }
$$

FACULDADE DE FILOSOFIA, LETRAS E CIÊNCIAS HUMANAS DEPARTAMENTO DE LETRAS CLÁSSICAS E VERNÁCULAS PROGRAMA DE PÓS- GRADUAÇÃO EM FILOLOGIA E LÍNGUA PORTUGUESA

\title{
Estudo da polifonia nas notícias da Folha de S. Paulo relativas à educação
}

\author{
Tânia Aiko Aragute
}

Orientadora: Profa. Dra. Maria Lúcia C. V. O. Andrade

São Paulo

2010 


$$
\text { UNIVERSIDADE DE SÃO PAULO }
$$

FACULDADE DE FILOSOFIA, LETRAS E CIÊNCIAS HUMANAS DEPARTAMENTO DE LETRAS CLÁSSICAS E VERNÁCULAS PROGRAMA DE PÓS- GRADUAÇÃO EM FILOLOGIA E LÍNGUA PORTUGUESA

\title{
Estudo da polifonia nas notícias da Folha de S. Paulo relativas à educação
}

\author{
Tânia Aiko Aragute
}

\begin{abstract}
Dissertação apresentada ao Programa de Pós-Graduação em Filologia e Língua Portuguesa, do Departamento de Letras Clássicas e Vernáculas, da Faculdade de Filosofia, Letras e Ciências Humanas, da Universidade de São Paulo, para a obtenção do título de Mestre em Letras.
\end{abstract}

Orientadora: Profa. Dra. Maria Lúcia C. V. O. Andrade

\author{
São Paulo
}


Banca Examinadora

(2) 
À minha família que sempre esteve presente durante toda a minha vida, principalmente aos meus pais que não apenas me trouxeram a este mundo, mas me ensinaram o caminho da verdade. 


\section{AGRADECIMENTOS}

Agradeço à minha orientadora, Maria Lúcia C. V. O. Andrade que com muito carinho, dedicação, companheirismo e paciência me conduziu desde a minha iniciação científica, na graduação até o fechamento desta dissertação.

Aos membros de minha banca de qualificação, Professores Doutores Paulo Eduardo Ramos e Alessandra Castilho Ferreira da Costa pelas sugestões feitas durante o exame.

Agradeço, também previamente aos Professores Doutores Paulo Eduardo Ramos e Ana Rosa Ferreira Dias por gentilmente fazerem parte da minha da minha banca de defesa.

Agradeço de forma carinhosa e especial a Franciny, Rafaela e Renata pelos conselhos e opiniões dado ao longo do desenvolvimento do trabalho.

A Mariana pelas fotos tiradas dos jornais e pelas tardes passadas comigo no Banco de Dados da Folha de S. Paulo para a compilação do corpus.

Ao meu amigo Thiago presente tanto nos meus problemas pessoais quanto aos de informática durante a feitura deste trabalho.

A Edite da Secretaria da Educação da Prefeitura de Guarulhos, sem ela não seria possível a freqüência nas disciplinas do mestrado, ela sempre compreendeu a minha luta e a vontade de finalizar esta dissertação.

A todos os amigos e familiares que de alguma forma contribuíram para a realização deste trabalho 
(...) compreender o mundo pelo modelo da imprensa não significa compreendê-lo de fato, mas apenas isso, 'compreender o mundo pelo modelo da imprensa', um fim em si. (Serva, 2005, p. 61) 


\section{RESUMO}

ARAGUTE, Tânia Aiko (2011). Estudo da polifonia nas notícias da Folha de S. Paulo relativas à educação. Dissertação de Mestrado (Filologia Portuguesa). São Paulo: FFLCH/ USP.

Nesta dissertação, temos por objetivo estudar a polifonia em notícias relacionadas à Educação, publicadas no jornal Folha de S. Paulo, nas décadas de 1930, 1940, 1970 do século XX e na primeira década do século XXI, sob a perspectiva teórica da Análise Crítica do Discurso. Para tanto, foram selecionadas 30 notícias com o objetivo de investigar a construção argumentativa do texto, a partir da inserção de outras vozes presentes, bem como os atores sociais responsáveis por tais declarações. Considerando que a polifonia é uma categoria que vai além da simples introdução de uma voz ou de um efeito de autoridade no texto, analisaremos o uso dos discursos direto e indireto. No discurso direto, marcado pelas aspas, o enunciador se apropria da fala do outro e a "transcreve" para talvez se ter um maior distanciamento do que é dito. Já o discurso indireto é entremeado pela fala do ator social, sem o uso das aspas, no qual o enunciador disserta, com suas próprias palavras, sobre o que foi dito pelo outro. Nesse jogo de vozes e atores os discursos inseridos nas notícias formam um processo argumentativo, pois o simples fato de o enunciador escolher uma declaração e não outra implica uma estratégia argumentativa.

Palavras-chave: Análise Crítica do Discurso; Discurso Jornalístico; Notícia; Polifonia. 


\begin{abstract}
ARAGUTE, Tânia Aiko. Polyphony in news stories on education from Folha de S. Paulo. Master's Thesis (Portuguese Philology). São Paulo: FFLCH/ USP.

This research aims to study polyphony in news stories related to education, as published in the newspaper Folha de S. Paulo, in the 1930s, 1940s, 1970s, and in the first decade of the 20th century, under the theoretical framework of the Critical Discourse Analysis (CDA). We have selected 30 news stories to investigate the construction of arguments from the different voices in the text, in addition to social actors uttering such statements. Based on the idea that polyphony is a linguistic construction that goes beyond the mere introduction of different points of view in the utterance, or authority effects of the text self, we analyze the use of quoted and reported speeches. In quoted speech, which appears within quotation marks, we say exactly what someone has said word by word to attain a detachment effect from what is said. On its turn, reported speech does not use quotation marks to enclose what the person said and it does not have to be word by word, and when reporting someone else's speech we are usually talking about a time in the past. In this game of voices and actors, the discourse inserted into news articles make up an argumentative process because by simply uttering one thing and not another Implies an argumentative strategy.
\end{abstract}

Keywords: Critical Discourse Analysis; Journalistic Discourse Analysis; News; Polyphony. 
ABREVIATURAS

ACD - Análise Crítica do Discurso

FSP - Folha de São Paulo

MRFSP - Manual da Redação - Folha de S. Paulo 


\section{SUMÁRIO}

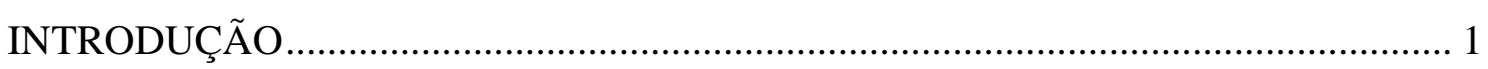

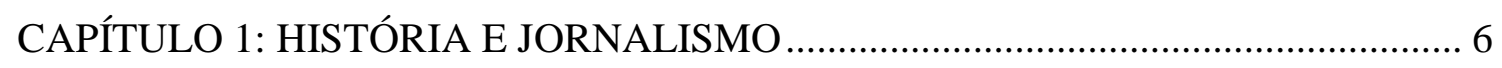

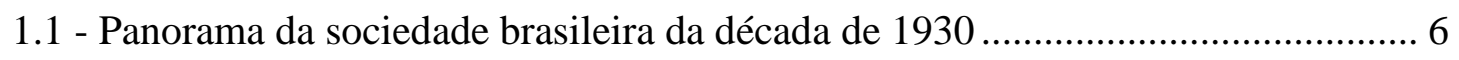

1.1.1 - Getúlio Vargas sobe ao poder ................................................................... 8

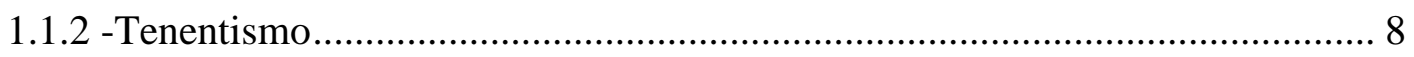

1.2 - Panorama da sociedade brasileira da década de 1940 ........................................ 10

1.3 - Panorama da sociedade brasileira da década de 1970 ......................................... 11

1.3.1 - Regime Militar (1964-1985) ...................................................................... 11

1.3.2 - Governo Castelo Branco ......................................................................... 11

1.3.3 - O governo Costa e Silva ......................................................................... 12

1.3.4 - O governo Médici ................................................................................. 13

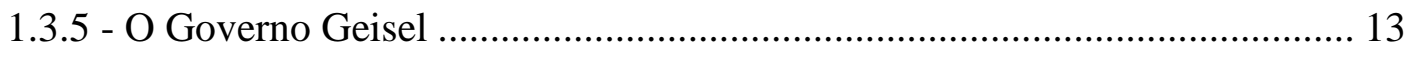

1.3.6 - O governo Figueiredo .......................................................................... 14

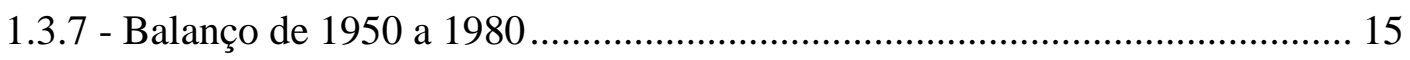

1.4 - História da Educação ...................................................................................... 15

1.5 - História do jornalismo impresso ......................................................................... 19

1.5.1 - História da Folha de S. Paulo (FSP) ……………………………………... 25

1.6 - Manual da Redação: Folha de S. Paulo (MRFSP) ............................................. 31

CAPÍTULO 2: A ANÁLISE CRÍTICA DO DISCURSO: O GÊNERO NOTÍCIA E A

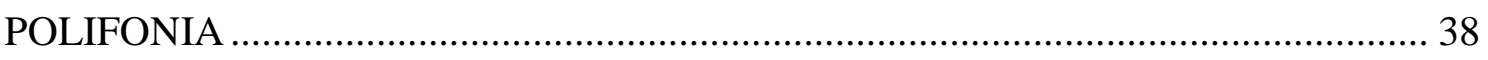

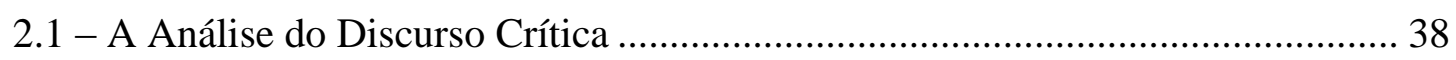

2.1.2 Discurso direto e Discurso indireto .................................................................... 41

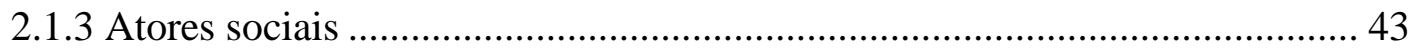

2.2 - O gênero discursivo notícia: definição ……………………………………........ 47

2.2.3 Bakhtin e seu Círculo ............................................................................... 48

2.2.4 - Configuração do gênero notícia na atualidade ............................................ 50 
2.3 - A argumentação: estratégias discursivas e a construção da notícia..................... 54

2.4 - A polifonia: vozes conjuntas ou divergentes na construção da notícia .............. 59

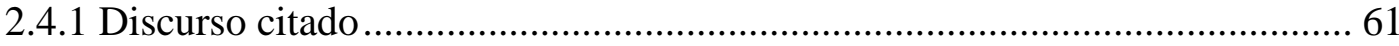

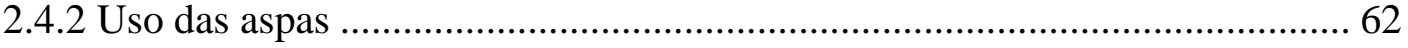

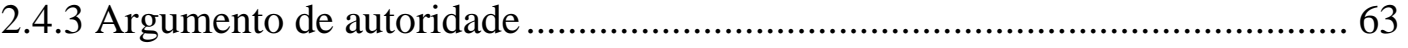

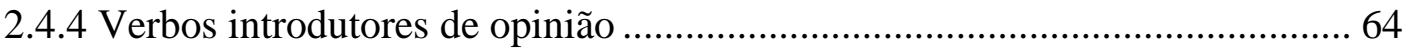

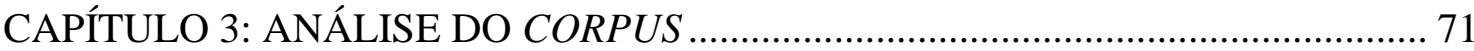

3.1 - Notícias das décadas de 1930 e 1940 .................................................................. 72

3.1.2 - Características marcantes no corpus das décadas de 1930 e 1940 ............... 95

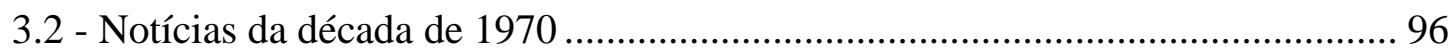

3.2.1 - Características marcantes no corpus da década de 1970 .......................... 117

3.3 - Análise do corpus da primeira década do século XXI (2000 a 2009)............... 118

3.3.1 - Características marcantes no corpus na primeira década do século XXI .. 147

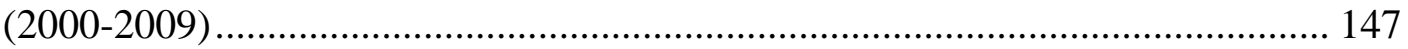

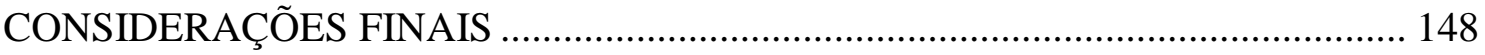

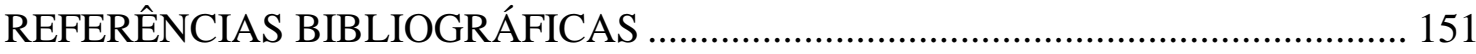

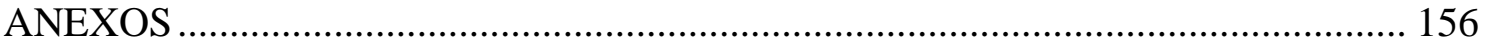

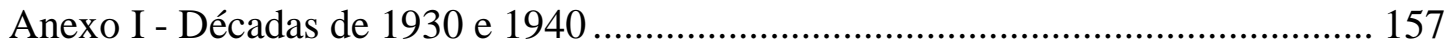

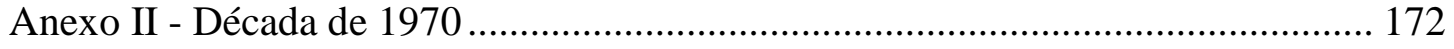

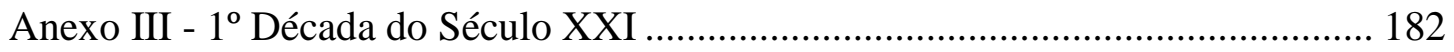




\section{INTRODUÇÃO}

Nesta pesquisa, temos por objetivo desenvolver um estudo da polifonia em notícias relacionadas à Educação, publicadas no jornal Folha de S. Paulo nas décadas de 1930, 1940, 1970 do século XX e na primeira década do século XXI. Essas datas foram privilegiadas em nosso trabalho, pois ocorreram fatos históricos importantes tanto no campo político-social, como na esfera educacional. Entre esses fatos, destacam-se: o primeiro governo de Getúlio Vargas, na década de 1930 e 1940, período em que foi instituído o ensino primário gratuito e de frequência obrigatória, e a ditadura militar; com o general Médici, na década de 1970, período em que se destaca o ensino técnico profissionalizante no Brasil. A escolha da década atual é importante para nossa pesquisa para se proceder a um estudo comparativo com as demais.

O corpus relativo ao início do século XXI é constituído por notícias publicadas no jornal Folha de S. Paulo entre os meses de março e abril, por se tratar do início do ano letivo em que as notícias relativas à educação aparecem com uma freqüência maior em relação aos outros meses do ano.

Uma vez que alguns temas sobre educação compõem assuntos divergentes e complexos por envolver muitos interesses conflitantes, pretende-se aqui analisar a argumentatividade das partes antagônicas que, a partir das inserções dos discursos direto e indireto, dentro da notícia, defendem ou refutam tais tipos de avaliações.

Nesse sentido, a apresentação deste trabalho torna-se importante, pois divulga esse material relativo ao gênero notícia e o analisa a partir de uma perspectiva diacrônica e crítica, contribuindo para os estudos referentes à Análise Crítica do Discurso e em certa medida, ao Jornalismo, dado que os textos são constituídos por meio do uso de estratégias pré-selecionadas, conforme aponta o Manual da Redação: Folha de S. Paulo.

Tendo como ponto de análise a polifonia nas notícias sobre Educação no jornal Folha de S. Paulo, surge, então, uma questão: a polifonia seria apenas a inserção de vozes dentro do texto? Uma notícia sobre a suspensão das aulas em uma escola por falta d'água, por exemplo, terá repercussão diversa se o jornalista apresentar declarações de 
mães de alunos ao invés de a voz predominante ser a do ministro da Educação e viceversa?

Segundo Van Dijk (1992), "quando se analisa a notícia, analisa-se, sobretudo, seu conteúdo, que é, sem dúvida, importante, mas é apenas a metade da história, literalmente" (p. 129). Desse modo, não só o conteúdo é importante, mas também as estratégias linguísticas empregadas para construir esse conteúdo, o momento histórico de produção, a linha editorial do jornal, o enunciador, o enunciatário etc.

A polifonia, assim como a linguagem em geral, pode apresentar diferentes intencionalidades, dependendo dos objetivos do enunciador e quais os efeitos de sentido que se busca alcançar. Podemos dizer, então, que o estudo da polifonia é de suma importância para entendermos o processo de construção argumentativa do texto, pois a escolha de argumentos e vozes nos diz muito do lugar em que o enunciador se encontra, qual a sua opinião sobre determinado assunto, como o seu discurso é construído.

Uma pesquisa diacrônica como a que estamos propondo deve levar em conta a relação entre a produção da notícia e o contexto sócio-histórico-ideológico, o que pode revelar a intencionalidade do enunciador, lembrando que a partir da escolha de uma determinada voz e não de outra, o jornalista induz o leitor a uma determinada opinião em relação a determinado evento social.

Considerando que o estilo da notícia é marcado pelo ideal de objetividade e que o texto jornalístico deve ser de fácil compreensão para o destinatário da mensagem, partimos do pressuposto segundo o qual para a construção da notícia devem ser utilizadas diferentes estratégias linguísticas de forma a torná-la legível e facilmente compreensível aos diversos grupos de leitores, os quais podem possuir interesses, concepções e conhecimentos de mundo diversos.

No Manual da Redação: Folha de S. Paulo após ser chamada a atenção para se evitar a emotividade e o sensacionalismo, aparece uma orientação que é a seguinte: "A busca de objetividade jornalística e distanciamento crítico são fundamentais para garantir a lucidez quanto ao fato e seus desdobramentos concretos" (p. 22). A partir desse ponto de vista, pretendemos desenvolver um estudo a respeito do gênero discursivo notícia, em que questionamos se a "objetividade jornalística", que a Folha de S. Paulo tanto preza, existe de fato. 
Em geral, um jornal é lido de maneira seletiva. O leitor decide o que realmente é de seu interesse, sem que haja a necessidade de ler todas as notícias de um jornal. Por isso, nos textos jornalísticos, é usado o princípio do lead, que consiste na apresentação de uma notícia nos primeiros parágrafos respondendo a seis questões: “Quem?, Como?, Onde?, Quando?, O quê? e Por quê?". Para o Manual da Redação: Folha de S. Paulo, o lead é:

Imprescindível à valorização da reportagem e útil à dinâmica da leitura contemporânea- por ser uma síntese da notícia e da reportagem-, não existe, no entanto, um modelo para redação do texto do lide. Nem pode ele ser realizado de maneira automática, com escrita burocrática. (p. 28 e 29).

As informações consideradas mais importantes aparecem, contrariando a ordem natural de uma narrativa, logo no início da manchete e no subtítulo, depois, apresenta-se o parágrafo de lead e, então, o corpo do texto (body) é desdobrado.

Visto que não se trata de um processo aleatório, mas de uma produção escrita que segue determinadas regras, não consideramos que a notícia seja imparcial, pelo contrário, como em toda produção linguística, podemos nela encontrar estratégias de seleção que orientam o sentido do texto. Para os estudiosos de textos como Brandão (1998), Maingueneau (2002), Marcuschi (2007), entre outros, a simples seleção de eventos a serem reproduzidos já implica escolhas, argumentação e o encaminhamento do discurso para determinadas conclusões. Por isso, torna-se utópica a noção de exposição de ideias objetivas, sem nenhum posicionamento pessoal, pois toda linguagem é constituída de intencionalidade. Nesse processo, incluímos a polifonia, na medida em que todo enunciado possui uma orientação argumentativa.

Desse modo, podemos investigar, neste trabalho, se a simples seleção de eventos a serem reproduzidos na notícia já implica uma orientação argumentativa que encaminha o discurso para determinadas conclusões. Além disso, se toda linguagem é constituída de intencionalidade, inclusive a polifonia, entendemos ser de suma importância um trabalho que coteje tal objeto de estudo.

Com o propósito de desenvolver uma pesquisa a respeito dessa estratégia linguística em notícias publicadas no jornal Folha de S. Paulo, este trabalho objetiva contribuir para o Projeto História do Português Paulista (PHPP - conhecido como Projeto Caipira sob a coordenação geral do Prof. Ataliba Teixeira de Castilho), já que 
se trata de um corpus constituído por textos de diferentes épocas, o que propicia a verificação da língua usada pela sociedade nesses diferentes momentos da história. Trata-se de textos que foram produzidos em determinado contexto sócio-histórico, fazendo com que o estudo de notícias, em uma perspectiva diacrônica, contribua para a pesquisa e análise do português paulista e, consequentemente, do português brasileiro.

Dessa maneira, no primeiro capítulo, tratamos primeiro da perspectiva histórica baseando-nos, principalmente, em Fausto (2009) e Pierucci (2007) nas décadas aqui analisadas: 1930, 1940 e 1970 com o intuito de contextualizar o corpus e o leitor, fazendo-se dessa maneira uma Análise Crítica do Discurso sob a luz da historicidade. Depois abordamos a história da educação nesses mesmos períodos e, por último, contemplamos a história do jornalismo impresso, que inclui a história da Folha de $S$. Paulo e de seu manual de redação.

No segundo capítulo, conceituamos o gênero notícia e abordamos a polifonia de acordo com os diversos autores, mas restritamente, neste trabalho, à perspectiva do discurso direto e discurso indireto.

Já no terceiro capítulo, apresentamos a análise do corpus precedida sempre de uma tabela em que os discurso direto e indireto são selecionados, bem como os atores sociais atribuídos aos discursos. A base da análise está nos estudos de Marcuschi (2007) que dissertou sobre os verbos introdutórios de opinião e fez uma tipologia desses verbos em sete funções diferentes. Já o trabalho de Grillo (2001) quanto aos modalizadores e a construção das tabelas foi, também, de suma importância para a análise, bem como os estudos de atores sociais elaborado por Van Leuween (1997).

Cabe destacar que a análise do corpus estabelece um diálogo entre as teorias tratadas anteriormente ao longo da dissertação, fazendo um paralelo entre teoria e análise e buscando respostas para o que foi proposto neste trabalho. 
Não existe objetividade em jornalismo. Ao escolher um assunto, redigir um texto e editá-lo, o jornalista toma decisões em larga medida subjetivas, influenciadas por suas posições pessoais, hábitos e emoções. (Manual da Redação Folha de S. Paulo, 2010, p. 46) 


\section{CAPÍTULO 1: HISTÓRIA E JORNALISMO}

Para que se tenha um maior entendimento do jornalismo impresso e, consequentemente, da transformação pela qual passou o gênero notícia ao longo das décadas aqui analisadas, se faz necessário um levantamento histórico da constituição e evolução da sociedade brasileira nas décadas de 1930, 1940, 1970 (século XX) e do início do século XXI. Esse levantamento histórico é importante porque o jornal impresso está estritamente ligado à Cultura, Economia, Política e Educação da sociedade brasileira, no período em que circulou. Outro ponto a ser levado em consideração é que pela Análise Crítica do Discurso (doravante ACD) tanto a notícia reflete o que se passou naquele momento histórico, quanto o que se sabe da história se reflete nas notícias. Esse jogo de vai e volta entre a notícia e a história é verdadeiro, mesmo com algumas interferências.

Se por um lado a notícia está voltada para o presente, para o novo e até antecipa, muitas vezes, o que irá acontecer; por outro lado, a história está voltada para o passado e necessita de distanciamento cronológico para que se obtenha uma análise mais profunda e clara. Ao contrapor notícias relativas a determinado período histórico com os livros de história que relatam esse mesmo período, podemos notar que certos pontos convergem e outros divergem, nem tudo o que foi noticiado na época constitui-se de fato real, como se pode verificar ao longo do tempo.

\section{1 - Panorama da sociedade brasileira da década de 1930}

Segundo Fausto (2009), a partir da década de 1930, iniciou-se, no Brasil, um processo de urbanização, principalmente em São Paulo, que era um Estado caracterizado como um grande distribuidor de produtos importados. Nessa época, o Brasil era um país baseado em uma economia agrária e o café era o seu principal produto de exportação.

No campo político militar, de acordo com Fausto (2009), entre 1910 e 1914, época do governo de Marechal Hermes, tínhamos os "salvacionistas" que desejavam 
"reduzir o poder das oligarquias nas áreas onde isso parecia mais fácil e onde eram mais chocantes as desigualdades sociais." (p.313).

Anos depois, houve o movimento do tenentismo, espécie de "herdeiros" dos "salvacionistas", que, segundo o historiador, se contrapuseram às propostas que tinham antes de ascender ao poder, em 1930. Conforme Fausto (2009), os tenentes tinham como propósito “(...) dotar o país de um poder centralizado, com o objetivo de educar o povo e seguir uma política vagamente nacionalista.” (p.314).

Assim, para explicar a tomada de poder de Getúlio Vargas e suas consequências, é necessário refletir sobre a Revolução de 1930. Tal revolução marcou o fim da primeira República e iniciou-se por desentendimentos sobre o nome a ser indicado para candidato às eleições presidenciais. O então presidente, Washington Luís, queria indicar um representante de São Paulo, Júlio Prestes, o que não foi visto com bons olhos por parte de mineiros e gaúchos. Daí surge o nome de Getúlio Vargas como candidato à presidência pelo partido chamado Aliança Liberal, que tinha como foco sensibilizar a classe média e as classes dominantes regionais não associadas ao núcleo cafeeiro.

Júlio Prestes ganhara as eleições em $1^{\circ}$ de março de 1930 , com votos forjados, o que principiou, em outubro de 1930, a Revolução em Minas Gerais e no Rio Grande do Sul. Uma das batalhas, a chamada Batalha de Itararé, tinha por objetivo a deposição do presidente, que não ocorreu de fato, pois para Fausto (2009):

(...)antes do confronto decisivo, a 24 de outubro, os generais Tasso Fragoso, Mena Barreto e Leite de Castro, pelo Exército, e o almirante Isaías Noronha, pela Marinha, depuseram o presidente da República no Rio de Janeiro, constituindo uma junta provisória de governo. (p. 325).

E assim foi a ascensão de Getúlio Vargas ao poder. No entanto, Vargas foi apoiado por um grupo heterogêneo, ao qual ele teria que prestar contas mais tarde. Segundo estudos de Fausto (2009), no seu grupo de apoio estavam pessoas dos mais diferentes níveis sociais e políticos, todos contra o poder vigente, como, por exemplo, os velhos oligarcas, típicos representantes da classe dominante de cada região do país, que desejavam maior atendimento à sua área e maior soma de pessoal de poder, com um mínimo de transformação. 


\subsection{1 - Getúlio Vargas sobe ao poder}

Em outubro de 1930, Getulio Vargas sobe ao poder como chefe do governo provisório, permanecendo no cargo durante 15 anos. Em 1950, é eleito pelo voto popular, mas não chegou a cumprir seu mandato por ter se suicidado.

Getúlio Vargas toma o poder em um período delicado da história, pois, na década de 1930, havia uma grande crise mundial devido à "quebra" da bolsa de Nova Iorque, ocorrida em 1929. Tal depressão da economia afetou diretamente o Brasil e sua economia agrária, baseada somente no café. Para que as consequências não fossem mais devastadoras, o governo adotou como medida a compra do café para uma posterior queima. Essa medida beneficiou os cafeicultores que acabaram não "quebrando", apesar de toda a crise mundial.

O governo, que tinha também o apoio da Igreja Católica, tomou várias medidas centralizadoras, como quando dissolveu o Congresso Nacional e demitiu a maioria dos governadores, colocando em seu lugar interventores nomeados.

No entanto, Getúlio Vargas não foi somente um ditador que não realizou melhorias efetivas na vida das pessoas. Ele foi um grande interventor nas políticas trabalhistas e fortaleceu os trabalhadores instituindo: regulação do trabalho de mulheres e menores de idade, férias, limite de oito horas de trabalho. Tudo isso foi importante e consolidado em novembro de 1930 com a abertura do Ministério de Trabalho, Indústria e Comércio e Juntas de Conciliação e Julgamento que serviam como um intermediário para os conflitos entre patrões e empregados.

\subsection{2 -Tenentismo}

Segundo Fausto (2009), o tenentismo foi uma corrente político-militar que, quando passou ao governo, tinha como meta um programa de nacionalização dos meios de transportes e de comunicação, assim como a navegação de cabotagem. Os integrantes desse grupo defendiam que, para que isso acontecesse, havia a necessidade de um governo forte e centralizado, apoiando a continuação de Getúlio Vargas no poder e a elaboração de uma Constituição que estabelecesse a representação por classe, contando com empregadores e empregados ao lado da representação individual. Devido a 
pressões externas, houve a promulgação de um Código Eleitoral em que ficou estabelecida a obrigatoriedade do voto, seu caráter secreto e o direito de voto das mulheres.

Além disso, nessa época, não só o campo político se destaca, mas também o trabalhista e educacional, pois vários avanços foram obtidos a partir da Constituição de 14 de julho de 1934, tais como: salário mínimo, descanso semanal, férias remuneradas, indenização na despedida sem justa causa com relação aos direitos trabalhistas. No que diz respeito à educação, tema das notícias selecionadas neste trabalho, foram instituídos o ensino primário gratuito de frequência obrigatória e o ensino religioso de frequência facultativa.

Contudo, os acontecimentos políticos são preponderantes nesse período. Em 30 de março de 1935, é lançada a Aliança Nacional Libertadora (ANL), liderada por Carlos Lacerda, que tinha os seguintes objetivos: suspensão da dívida externa, reforma agrária, liberdade popular e constituição de um governo popular. Nesse ínterim, segundo Fausto (2009), na comemoração do dia 5 de julho de 1935, Carlos Lacerda, que se encontrava clandestino no Brasil, leu um manifesto de autoria de Prestes, pois este se encontrava escondido e também era um clandestino. Tal manifesto apelava pela derrubada do governo Vargas e pela tomada de poder por um governo popular, nacional e revolucionário.

Em março de 1936 como resposta à carta lida por Lacerda, a polícia invadiu o congresso prendendo os parlamentares que tinham alguma ligação com a ANL e criou também, em outubro desse mesmo ano, o Tribunal de Segurança, um órgão judiciário que ficaria sob o comando do governo

No início de 1936, houve candidaturas para as eleições, no entanto, isso foi interrompido por uma suposta insurreição comunista que ficou conhecida como plano Cohen, fato até hoje muito contestado em sua verossimilhança. Em 10 de novembro de 1937, é instaurado o Estado Novo por meio de uma Carta Constitucional, e Getúlio Vargas mantém-se no poder. 


\section{2 - Panorama da sociedade brasileira da década de 1940}

Para o historiador Boris Fausto (2009) é possível sintetizar o Estado Novo sob o aspecto socioeconômico, “(...) dizendo que representou uma aliança da burocracia civil e militar e da burguesia industrial, cujo objetivo comum imediato era o de promover a industrialização do país sem grandes abalos sociais.” (p. 367).

Nesse sentido, a grande industrialização ocorrida a partir de 1937 teve como principal propósito substituir os produtos importados que eram consumidos no país, por produção interna. Para que isso ocorresse, foram estabelecidas algumas medidas que tornavam campos e lugares estratégicos restritos somente aos brasileiros. Tais iniciativas tomadas em prol da industrialização refletiram na Educação, principalmente no ensino industrial, quando foi instituída, em 1942, a Lei Orgânica do Ensino Industrial e o Serviço Nacional de Aprendizagem Industrial (Senai).

No campo trabalhista, Getúlio Vargas era visto como o "pai dos pobres", como “protetor dos trabalhadores”. Em 1940, foi estabelecido o salário mínimo que consistia em remuneração adequada para suprimir as necessidades básicas do trabalhador, bem como, em junho de 1943, a Consolidação das Leis Trabalhistas (CLT). No entanto, antes disso, em agosto de 1939, foram decretadas a unidade sindical e algumas medidas que tornavam o sindicato mais dependente do Estado. E, em julho de 1940, foi criado o imposto sindical, uma tributação que determinava aos trabalhadores filiados ou não ao sindicato que pagassem um dia de seu trabalho a associações trabalhistas.

Quanto à política externa, o Brasil assinou um acordo comercial, em 1935, com os Estados Unidos e, em 1936, assinou outro com a Alemanha. Houve um impasse para o Brasil, na medida em que esses dois países acabaram pertencendo a eixos diferentes durante a Segunda Guerra Mundial. Esse impasse só foi resolvido quando cinco navios brasileiros, em 1942, foram bombardeados por submarinos alemães. Nesse momento, o país se declarou pró-aliados, ficando ao lado dos Estados Unidos e mandando tropas brasileiras para o combate.

$\mathrm{Na}$ época, destaca-se também a intensa censura no país, período em que não só foram proibidas as publicações que seriam "nocivas" aos brasileiros, como também o governo se utilizou de todas as mídias tanto para a propagação de suas ideias quanto para camuflar as crises e os descontentamentos da população em geral. Para isso, foi 
criado o Departamento Oficial de Publicidade (1931-1939), que mais tarde foi substituído pelo Departamento de Imprensa e Propaganda (DIP).

Em meados de 1943, o governo se viu enfraquecido e coagido pelos movimentos estudantis e pelos subterfúgios que a Imprensa utilizava para publicar notícias em desacordo com o governo em questão. Em fevereiro de 1937, Getúlio Vargas declara o Ato Adicional que abria as eleições gerais, no entanto, o mesmo foi deposto em 1945.

\section{3 - Panorama da sociedade brasileira da década de 1970}

Apesar de o Regime Militar ter perdurado de 1964 a 1985, analisaremos aqui, mais profundamente, a década de 1970, pois é deste período que foi retirado o corpus para análise desta dissertação.

\subsection{1 - Regime Militar (1964-1985)}

O militarismo ficou conhecido pela instauração de vários Atos Institucionais (AI), cujo primeiro deles foi baixado em 9 de abril de 1964 e consistia em: suspensão da imunidade parlamentar, perda dos direitos políticos por dez anos entre outras restrições para os magistrados, instalação de Inquéritos Policial-Militares (IPM) etc. Foi criado, de acordo com Fausto (2009), também o Serviço Nacional de Informações (SNI) que tinha por objetivo “(...) coletar e analisar informações pertinentes à segurança nacional, à contra-informação e à informação sobre questões de subversão interna.” (p.468).

\subsection{2 - Governo Castelo Branco}

O general Humberto de Alencar Castelo Branco foi eleito presidente no dia 15 de abril de 1964. Seu governo tinha como meta fazer uma "democracia restringida" e ser auto-suficiente economicamente. Para tanto, foi criado o Programa de Ação Econômica do Governo (PAEG) que reduziu o déficit do setor público, contraiu crédito privado, pôs fim à estabilidade no emprego após dez anos de serviços - o que era assegurado pela CLT - e fez a compressão dos salários. Esta última meta foi efetivada 
por meio de reajustes salariais inferiores à inflação. Além disso, no setor trabalhista, foi criado o Fundo de Garantia por Tempo de Serviço (FGTS), em setembro de 1966.

Quanto aos Atos Institucionais, o AI-1 foi seguido do AI-2 e AI-3, todos instituíram o reforço dos poderes do presidente e a extinção dos partidos políticos que existiam, só podendo haver dois partidos: a Aliança Renovadora Nacional (Arena) e o Movimento Democrático Brasileiro (MDB).

\subsection{3 - O governo Costa e Silva}

Em março 1967, quando Costa e Silva ganhou as eleições, o descontentamento da massa se revela por meio de movimentos estudantis e tem seu ápice na passeata dos 100 mil que aconteceu no dia 25 de junho de 1968, da qual participaram representantes da Igreja e da classe média do Rio de Janeiro.

Nas comemorações do dia 7 de setembro, o deputado Márcio Moreira Alves pediu um boicote à parada militar, incitando até as namoradas dos oficiais a ajudarem nessa empreitada fazendo greve de sexo. Assim, no dia 13 de dezembro de 1968, o presidente institui o AI-5 e fecha o Congresso.

Com o AI-5, foram estabelecidas a suspensão da garantia de habeas corpus, a perda de direitos e expurgos no funcionalismo, a censura dos meios de comunicação e a tortura. Segundo Fausto (2009), Costa e Silva sofreu um derrame e ficou incapaz de governar o país. Dessa maneira, a partir da instituição do AI-12, os ministros Lira Tavares, do Exército, Augusto Radamaker, da Marinha, e Márcio de Sousa e Melo, da Aeronáutica, assumiram temporariamente o poder.

Logo após, com o AI-13 foi criada a pena de exílio para o cidadão que se tornasse nocivo à segurança da nação brasileira, e, com o AI-14, foi instituída a pena de morte. Este recurso nunca foi usado formalmente; no entanto, as torturas e os desaparecimentos foram acontecimentos corriqueiros nesse período da história. 


\subsection{4 - O governo Médici}

O General Emílio Garratazu Médici subiu ao poder em 30 de outubro de 1974. Seu governo foi dividido em três áreas: militar, econômica e política, resultando, segundo Fausto (2009), em um dos governos mais repressivos da história brasileira. O governo usava a propaganda como um trunfo para manipulação política afirmando que o Brasil se desenvolvia bem em termos econômicos haveria um crescimento diante dos demais países. Os idosos chegaram a acreditar que, no milênio seguinte, o Brasil estaria equiparado em termos de desenvolvimento ao Japão. Tudo isso era embalado pela marchinha "Pra frente Brasil" e reforçado pela vitória brasileira na Copa do Mundo de 1970.

Assim, o Milagre Econômico durou de 1960 até 1973 devido a uma junção de crescimento econômico com baixas taxas de inflação. Houve tomadas de empréstimos aumentando a dívida externa de 40 bilhões de dólares, em 1967, para 97 bilhões, em 1972, chegando a 375 bilhões de dólares, em 1980. No entanto, o milagre econômico teve pontos negativos, tais como: excessiva dependência internacional; dependência de petróleo; má distribuição de renda; baixa dos indicadores de saúde, educação e habitação; falta de preocupação com o meio ambiente e, consequentemente, a desatenção com a preservação da natureza etc.

\subsection{5 - O Governo Geisel}

O general Ernesto Geisel foi escolhido para ser o presidente da República pelas Forças Armadas no ano de 1973. Seu governo foi marcado por vários conflitos, entre eles a invasão à Pontifícia Universidade Católica de São Paulo (PUC- SP) e repressão aos estudantes que estavam lá para reorganizar a União Nacional dos Estudantes (UNE); o "desaparecimento" e "suicídio" do jornalista e professor da Universidade de São Paulo (USP) Vladimir Herzog e do operário metalúrgico Manuel Fiel Filho.

Em julho de 1976, meses antes das eleições municipais, foi instituída a Lei Falcão que proibia os candidatos de ir às rádios e à televisão, podendo somente ser apresentados pelo nome, número e currículo, e fotografia, no caso da televisão. 
Em 1977, foram implantados: o "pacote abril" com o recesso do Congresso; o senador biônico para garantir a ARENA majoritária no Senado; a eleição indireta e a alteração do mandato de presidente da República de cinco para seis anos. Essas medidas foram executadas para impedir que o MDB chegasse ao poder, pois este se tornara o grupo político descontente com o governo e era constituído por pessoas com ideologias que iam desde liberais até socialistas.

A crise internacional do petróleo ocorreu em outubro de 1973 e como o Brasil importava $80 \%$ do que consumia, o governo acabou percebendo a fragilidade econômica do país e lançou o II Plano Nacional de Desenvolvimento (PND) que defendia a autonomia a partir dos investimentos para elementos básicos como o petróleo, aço, alumínio etc. Um dos ícones da II PND foi a usina hidrelétrica de Itaipu.

Em agosto de 1977, o governo admitiu ter manipulado os índices de inflação nos anos de 1973 e 1974, prejudicando os trabalhadores que não tinham seus salários corrigidos corretamente. Foi grande o alvoroço contra o governo havendo greves e protestos que começaram em São Bernardo do Campo (município do Estado de São Paulo), liderados pelo representante sindical dos metalúrgicos, Luiz Inácio da Silva (Lula) e que foram repercutindo por todo o país.

\subsection{6 - O governo Figueiredo}

O general João Batista Figueiredo foi eleito pelo Colégio Eleitoral em 14 de outubro de 1978. Em seu governo, houve o segundo choque do petróleo. O sistema econômico internacional estava com juros altos, o que fez com que os empréstimos se tornassem cada vez mais difíceis e, quando liberados, estes tinham menor prazo para pagamento. Esse período ficou conhecido como de "estagflação" uma junção de estagnação econômica e inflação. 


\subsection{7 - Balanço de 1950 a 1980}

Destacados os aspectos políticos e econômicos, cabe apontar um panorama relacionado à população brasileira:

- A partir de 1960, o índice de envelhecimento cresceu e houve uma redução da taxa de fecundidade;

- Na década de 1970, houve um significativo aumento na expectativa de vida e um declínio na taxa de mortalidade infantil;

- Em 1980, a maior parte da população passou a ser urbana e a massas de produtores pobres continuou a crescer. Esta década ficou conhecida como década perdida, pois os trabalhadores assalariados diminuíram seu poder de compra.

\section{4 - História da Educação}

A Educação, como foi dito na introdução deste trabalho, não é aqui nosso foco, mas para que as notícias tivessem um tema em comum, selecionamos textos relacionados à Educação. Deixamos claro que este é um estudo, sobretudo, linguístico e que não abarca sentidos de valores quanto ao que é certo ou errado no sistema educacional, mas uma explanação sobre como esse sistema funcionava, levando-nos a entender melhor as notícias selecionadas em cada período.

Pierucci (2007) declara que a Educação, após 1930, sofreu um processo de democratização, cujas camadas mais populares da sociedade tiveram acesso à escola. É fato que isso não ocorreu de um dia para outro e que nem todos tinham condições reais de frequentar a escola. Embora no período anterior fosse restrita aos mais afortunados, agora a Educação se tornava um pouco mais aberta. Isso pode ser comprovado com o relativo aumento das matrículas e a uniformização do ensino. Se em 1920 3,4\% da população estava matriculada no ensino de nível primário, já na década de 1970 a porcentagem de matrícula era de $14,7 \%$, o que demonstra um grande avanço.

Outro passo importante é com relação à educação de adultos que não puderam estudar na idade apropriada, o que hoje chamamos de EJA (Educação de Jovens e Adultos). Em 1945, eram 138.562 matriculados e esse número cresceu para 484.498 no 
ano de 1959. Na década de 1970, o Brasil foi considerado o país que, no mundo, mais diminuiu o número de analfabetos.

Ainda segundo Pierucci (2007), a expansão do ensino médio e a maior abertura dos cursos de supletivo fizeram com que houvesse uma expansão também dos cursos de ensino superior. Se em 1932 havia apenas 15.943 matriculados nas faculdades de todo o país, em 1976 as matrículas eram na ordem de 1.035.000. E o maior crescimento se deu da década de 1980 em diante. Tal crescimento desenfreado fez surgir também escolas superiores que não estavam tão comprometidas com a Educação em si, mas sim com os lucros obtidos pelas mensalidades pagas pelos alunos.

Na Constituição da República de 1891, a Educação foi separada em duas partes quase distintas: as universidades ficaram a cargo do poder Federal e os poderes Estaduais com os demais graus de escolaridade. No entanto, de acordo com Pierucci (2007), devido aos Estados terem parcos recursos, as escolas estaduais serviram, em sua maioria, como mantenedoras educacionais das camadas mais populares da sociedade. Todos os decretos que vieram depois tinham um caráter de unificação do secundário e uma organização dos cursos preparatórios para o exame de admissão à universidade. Voltando-se, ao longo dos anos, a uma educação mais humanitária e baseada não apenas em conteúdos, mas sim na formação social que esse indivíduo deveria ter perante a sociedade.

As diferenças entre as escolas de elite e as escolas voltadas para as classes menos favorecidas existem há muito tempo, como podemos ver no excerto do historiador Pierucci (2007) a seguir:

\footnotetext{
A legislação em vigor nas décadas de 40 e 50 preservava a antiga organização "dualista" do ensino, caracterizada como coexistência de algo como dois "sistemas" paralelos de educação, um para o povo em geral e outro para as elites, o primeiro iniciado na escola primária e continuado depois nas escolas profissionais de nível médio então existentes, e o segundo, igualmente iniciado na escola primária e continuado depois na escola secundária, organizada com a intenção de encaminhar sua clientela para as escolas superiores e para as posições mais privilegiadas na sociedade. (p. 482).
}

Quanto ao crescimento de matrículas no ensino médio, este se deu após 1945, pela pressão do povo. Devido a essa legislação dualista e à busca da massa popular pela 
igualdade de direitos, houve uma pressão social para que se ampliasse o número de vagas no ensino médio. De acordo com o autor:

(...) após a queda do Estado Novo. A deposição da ditadura e o fim da Segunda Guerra Mundial abriram possibilidades de manifestação de reivindicações antes reprimidas. Com a retomada do regime político baseado no voto, as aspirações populares de melhoria de vida mediante a passagem pela educação escolar encontram, no agente político em busca de eleitores, um defensor intransigente da necessidade de criação de mais escolas. (p.484).

Com a melhor estruturação educacional e a unicidade das diretrizes escolares deu-se o acesso à escolarização das camadas mais pobres da população, proporcionando, consequentemente, a ascensão social desse grupo. Assim, o estudo se tornou sinônimo de ascensão social e de uma vida financeira estável. O voto secreto, principalmente a partir de 1945, tornou um grande aliado do crescimento de escolas secundárias, pois era a partir dele que o povo pressionava o governo à abertura de novas escolas. Assim, para Pierucci (2007), “a escola secundária passou por mudanças qualitativas profundas: de escola seletiva, como ainda a definia a legislação federal de 1942, passou a escola comum, tendencialmente aberta a todos.” (p. 487).

Foi na Lei no .5692 de 11 de agosto de 1971 que surgiu a Reforma do Ensino em que se estabelecia a obrigatoriedade de 8 anos para o ensino comum (antiga $1^{\circ}$ a $8^{\circ}$ série) e o primeiro ciclo do ensino médio, sendo que ambos estavam integrados e ainda podiam ser respeitadas as necessidades locais de cada região, por exemplo, o calendário escolar pode ser diferenciado, nas áreas rurais, devido à época de colheita.

Outra questão importante que ocorreu no processo de democratização da Educação é que ela não foi feita de modo homogêneo por todo o território. Ao contrário, houve diferenças significativas entre determinadas regiões do país, principalmente no que se refere à escola rural, na maioria das vezes mais defasada em relação à escola das capitais, o que provocou modificações específicas.

Essa democratização do ensino, também não era "efetivamente" tão democrática, pois não é com a simples abertura de escolas e de matrículas que se obterá a inclusão de um aluno no sistema educacional. Esse aluno precisa de outros subsídios para poder frequentar as aulas e prosseguir nos estudos. Isso é o que podemos perceber no excerto adiante, em que as crianças eram excluídas do sistema escolar. O Censo 
Escolar feito pela Prefeitura Municipal de São Paulo, segundo Pierucci (1997) diz que as crianças

(...) permaneciam excluídas da escola não por falta de oportunidades, mas porque suas condições de vida não as habilitavam nem ao menos à procura de ingresso na escola comum.

Não obstante o grande número de crianças que não chegam a ingressar na escola, o mais grave desafio que ora se coloca para o sistema escolar consiste na curta permanência dos alunos no ensino comum. As análises da situação educacional apontam a denominada "evasão escolar" como o principal indicador das deficiências de ensino. (p. 492).

Vários foram os fatores para que se explicasse o fracasso escolar, como: a repetência contínua; o conteúdo fora da realidade da comunidade local e do aluno; as escolas multi-seriadas com um único professor, quase sempre com parcos recursos; a própria democratização da educação que levou a camada mais popular da sociedade para a escola etc. No entanto, podemos levar em consideração que a "atuação educacional dos poderes públicos, no Brasil, após 1930, vem sendo orientada com vistas à extensão de um maior número de anos de escolaridade ao maior número possível de habitantes" (p. 501), segundo o Censo Escolar de 1997 relatado por Fausto (2009).

Dessa forma, podemos dizer que foram vários os projetos realizados pelo governo para a adequação da escola brasileira. Dentre elas temos: classes de recuperação, merenda escolar, distribuição de leite e do gestal ${ }^{1}$, pré-escola, cursos noturnos e supletivos. Este último tinha o caráter de melhoria não só da população adulta que não teve acesso à escola em idade própria, mas também a uma elevação cultural do sistema educacional em geral, pois o pai que frequenta as aulas dá valor aos estudos e adquire um conhecimento de mundo um pouco mais científico. Assim, provavelmente, esse pai incentivará e propiciará para seu filho melhores estudos; tornando-se, portanto, um propagador daquilo que aprendeu na escola dentro da própria casa, com relação à sua família, e fora de casa por meio de projetos sociais, com maior tomada de consciência de si como cidadão portador de direitos e deveres.

\footnotetext{
${ }^{1}$ Suplementação alimentar à gestante, à nutriz, e ao pré-escolar.
} 


\section{5 - História do jornalismo impresso}

Segundo Lage (1987), a evolução e circulação do jornal se iniciou na Alemanha. Em Bremem, no ano de 1609, e depois, no mesmo ano, em Estrasburgo, circularam os dois primeiros jornais. O terceiro jornal surgiu ainda na Alemanha, na cidade de Colônia, em 1610, e uma década mais tarde surgiram jornais em várias cidades européias, tais como: Frankfurt (Alemanha), Basiléia (Suiça), Hamburgo (Alemanha), Amsterdã (Holanda) e Antuérpia (Bélgica). A partir de então, jornais começaram a circular em diferentes partes do mundo.

Já na primeira Guerra Mundial, segundo Erbolato (2002), o jornal impresso era o principal meio de comunicação, ele imperava em relação às outras mídias da época, e somente foi superado, em 1920, após o surgimento da primeira radiodifusão nos EUA. Depois da primeira rádio e de sua expansão, a primeira revista a aparecer e fazer frente ao jornal impresso foi a revista Times (1923) que tinha um caráter noticioso.

Após 1945, houve uma grande mudança em todas as mídias por causa da popularização da televisão. Uma dessas mudanças aconteceu a partir dos estudos de John Hohenberg (EUA) que verificou ser a falta de interesse do público, em relação às notícias impressas, apenas uma dificuldade de compreensão, já que os textos eram escritos de maneira rebuscada. Houve uma mudança na postura dos jornalistas e a notícia passou a ser mais explicativa e didática. De acordo com Erbolato (2002) a inserção de:

(...) colunas interpretativas: análises de comentários das notícias feito por um especialista, geralmente residente na capital do país que procurava oferecer sua opinião autorizada sobre um fato, além de representar os antecedentes dos assuntos nacionais e internacionais correntes (p. 32).

Cabe destacar, portanto, que os primeiros jornais, feitos de forma manufaturada, não tinham a visão de lucro como um jornal-empresa de hoje. Cada jornal era marcado por sua ideologia política, partidária, de opinião. Atualmente, o que se vê é a preocupação com o leitor e com o que ele quer ler e ver, para que se consiga um maior escopo de venda e maior tiragem, gerando maior lucratividade. 
É por isso que Lage (1987) afirma que com essa radical mudança do jornal, a notícia "terminaria sendo a matéria-prima principal, conformando-se a padrões industriais através da técnica de produção de restrições do código linguístico e de uma estrutura relativamente estável.” (p. 13).

Uma mídia já existente sempre muda com o surgimento de uma nova, e isso não foi diferente com o jornalismo impresso. Este precisou superar o aparecimento do rádio e da TV, pois ambos tiraram do jornal impresso o furo e a edição extra, na medida em que já não se precisava mais do jornal para saber de uma notícia que acabara de acontecer - era preciso simplesmente ligar o rádio ou a TV para se manter informado. Assim, foi necessário ao jornal se adaptar e melhorar seu modo de produção para que não se atrofiasse e se extinguisse. Houve uma melhoria de edição e organização, uma vez que os jornais produzidos anteriormente não possuíam alta qualidade de editoração e não eram bem paginados.

O jornal impresso se tornou, assim, um complemento do que o rádio, a televisão - e hoje em dia a internet - trazem para o público. Segundo Melo (1979), o jornal trata o tema com maior profundidade, didatismo e dá ao leitor a possibilidade de absorção da informação no momento em que for oportuno e viável, não é fugaz como uma notícia televisionada ou transmitida pelo rádio. $\mathrm{O}$ jornal impresso tem seu momento e pode ser guardado por mais tempo.

Outro aspecto a ser levado em consideração é a questão da organização, tendo em vista a quantidade de informações. Em contraponto, uma visão mais atual, de Serva (2005), questiona a falta de entendimento por parte do leitor, hoje em dia, devido a uma avalanche de informações, em que não há uma efetiva organização do caos, o autor, no trecho a seguir, discorre sobre os conflitos na Iugoslávia, afirmando que:

(...) se os leitores conhecessem a história, talvez soubesse que a guerra é um fato constante, recorrente. Então, não se surpreenderiam com notícias de cada época específica, que a rigor são 'suítes' de velhas notícias.

Ao contrário, a dificuldade de entendimento que muitos leitores revelam que o jornalismo não organiza de fato o caos. Embora procure ser um espelho organizado e classificado do mundo, a imprensa, por seu sistema essencial de produção, mantém e, mais ainda, gera confusões na cabeça de leitores. (p. 60). 
A dificuldade de compreensão, segundo o referido autor, pode ser advinda das "falsas manchetes" que, na verdade, são fatos ocorridos ao longo da história, mas que sempre aparecem nas notícias sob uma roupagem nova, deixando o leitor, muitas vezes, desnorteado, apesar "de serem metralhados diariamente por um cem-número de informações" (p.62).

Nesse sentido, é importante destacar a relevância ou não, a repercussão ou não, de uma dada notícia, levando-se em conta que um jornal é constituído, em sua maior parte, por esse gênero. Se, por um lado, o jornalista retém a notícia por ter uma fonte tipo $2^{2}$, ou seja, não muito segura; por outro lado, ele pode ser superado por outro jornal que lançou um furo, mesmo que não fosse ainda comprovado.

Foi exatamente isso que aconteceu no Caso Escola Base, escrito por Ribeiro (1995). Os jornais se anteciparam ao divulgar acusações de pedofilia que, segundo denúncias, teriam ocorrido dentro de uma escola infantil chamada "Escola Base". A maioria dos jornais, para não ficar atrasada em relação aos demais veículos de comunicação, acabou se antecipando na divulgação das notícias e atrapalhando as devidas investigações. Segundo Ribeiro, os dois casais acusados injustamente ainda tentam superar as acusações morais e problemas financeiros com o fechamento da escola.

$\mathrm{O}$ autor faz uma comparação entre animus narrandi e animus denunciandi, no qual o primeiro é a intenção e a própria função do jornal que é de narrar, noticiar os fatos que acontecem; e o segundo, é compulsão por denunciar, em que o jornalista não leva em conta se a fonte é confiável ou não, ou se é preciso um maior detalhamento dos fatos, muitas vezes acobertando denúncias sem fundamentos e maledicentes, colocando as fontes em $o f f^{3}$, ou seja, faz uso de um instrumento que deveria ser para preservar a imagem de pessoas, perante uma possível retaliação, servir como um subterfúgio para denúncias severas, que culminou, por exemplo, no Caso Escola Base (Ribeiro, 1995). Talvez esse uso de várias fontes off, no Caso Escola Base, tenha-se dado porque a

\footnotetext{
2 Apresentaremos e discutiremos detalhadamente a classificação das fontes no item 1.6-Manual da Redação: Folha de S. Paulo no Capítulo I.

${ }^{3}$ Fontes em off é um artifício que o jornalista usa para proteger a fonte de eventuais represálias, mas tal estratégia pode servir como subterfúgio para alguns jornalistas mal intencionados encobrirem uma fonte de caráter duvidoso. (cf. Ribeiro, 1995, p. 161)
} 
notícia tomou grandes proporções e comoção social, e a partir daí houve várias suítes ${ }^{4}$ em torno desse fato.

Como já foi dito por Lage (1987), Erbolato (2002), Serva (2005), entre vários outros autores que dissertaram sobre Jornalismo, o fundamental de uma notícia é a novidade; portanto, quanto mais suítes houver, mais informações novas são necessárias todos os dias para chamar a atenção do leitor.

Desse modo, seria provável que no atropelamento dos fatos dO Caso Escola Base, qualquer denúncia de uma mãe ou de uma vizinha poderia ser levada como verdadeira e nova para a suíte do outro dia sem levar em conta a confiabilidade da fonte. Tal fato poderia ter sido evitado se o copidesque, mais conhecido como redator do jornal, tivesse feito a edição e investigado melhor os fatos, ao invés de imprimir uma notícia baseada apenas na visão do jornalista que foi colher informações do caso e não em fatos concretos e contundentes. O papel de um copidesque é manter-se na Redação e selecionar/retirar aquilo que for excesso de emoção do jornalista que escreveu a dada notícia. Segundo Rossi (1994), “a forma final em que a notícia vai aparecer no jornal é, muitas vezes, mais a de quem não viu o acontecimento do que a de quem o presenciou" (p. 29).

Isso nos leva a algumas conclusões: a notícia não é construída como ela aparece todos os dias de manhã no jornal, dentro dela há a edição, os recortes, às vezes devido a falta de espaço no jornal, ou ao fato de o copidesque ter a autonomia dentro do jornal para mudar a notícia, se for conveniente. Podemos nos antecipar um pouco e dizer que a notícia em si é polifônica, na medida em que ela representa as várias vozes das pessoas pelas quais passou, com diferentes opiniões, conhecimentos de mundo e interesses. Dessa maneira, a notícia passa por várias etapas de adaptação até chegar aos moldes mais "adequados" para o jornal.

Nesse sentido, a mídia em si é poderosa e ela tem o poder de manipular, de persuadir e até de controlar, de certa forma, as massas, a sociedade em si. Um exemplo clássico desse poder da mídia é a chamada hipótese da agenda sitting, que de acordo com Barros Filho (1995):

As pessoas agendam seus assuntos e suas conversas em função do que a mídia veicula. É o que sustenta a hipótese da agenda setting. Trata-

\footnotetext{
${ }^{4}$ Suítes são matérias publicados em dias seguintes e que dão prosseguimento a um determinado assunto.
} 
se de uma das formas possíveis de incidência da mídia sobre o público. É um tipo de efeito social da mídia. É a hipótese segundo a qual a mídia, pela seleção, disposição e incidência de suas notícias, vem determinar os termos sobre os quais o público falará e discutirá. (p. 169)

Desse modo, parece haver um direcionamento que induz as pessoas a falarem do "assunto do momento". Isso ocorre, por exemplo, no período de eleições em que há notícias diárias sobre as atividades de cada candidato. Foi assim também com escândalos políticos ou temas de grande impacto como: a Queda do Muro de Berlim, no Impechmment do presidente Collor, na questão do Mensalão, no caso Isabella, entre outros. A agenda sitting não determina sobre o que os cidadãos vão falar, mas dá um leque de opções, pautando as conversas cotidianas do dia seguinte.

Já para Serva (2005), a notícia é uma repetição de acontecimentos que, em uma perspectiva crítica e histórica, não são fatos novos e alheios à cultura daquela determinada região, mas que, no jornal, é apresentada como um fato novo e chocante. $\mathrm{O}$ exemplo que o autor utiliza em seu livro é a sucessão de notícias sobre corpos de combatentes encontrados mutilados em períodos e em lugares diferentes da Iugoslávia. Uma pessoa com uma visão histórica, crítica e que tenha a memória desse acontecimento teria como fazer a associação e concluir que retirar os olhos dos perdedores de guerra é quase que um costume nesse país e não veria uma notícia sobre isso como uma novidade. Esse fato estaria muito mais ligado aos costumes e valores locais do que a algo verdadeiramente surpreendente e estranho à comunidade local.

O que permite supor que os fatos, embora separados no tempo cronológico, fazem parte de uma única cadeia, uma única ocorrência histórica da qual cada 'notícia' é apenas uma manifestação, como um fotograma de filme de longa metragem (p. 24).

Dessa maneira, o autor vê a notícia com uma função a-histórica, na medida em que ela não nos deixa ver a perspectiva dos fatos como procedentes de uma série de eventos culturais anteriores, e a maioria das manchetes não se justificaria como tal, por trazer em si fatos corriqueiros, os fatos se repetem, e temos sempre um pouco mais do mesmo que já foi noticiado, uma nova estratégia política que já foi usada tempos atrás. Nessa perspectiva, segundo Serva (2005), a notícia é vista como algo que é: 
aparecer vestidos de novos, maquiados para voltar a surpreender (p. $50)$.

Lage (1987) discute não somente a falta de conexão histórica entre as notícias impressas veiculadas pelo jornal, mas também a não profundidade, o não questionamento, a não relação dialética entre os fatos, como vemos no excerto que se segue:

O universo das notícias é o das aparências do mundo; o noticiário não permite o conhecimento essencial das coisas, objeto de estudo científico, da prática teórica, a não ser por eventuais aplicações a fatos concretos. Por detrás das notícias corre uma trama infinita de relações dialéticas e percursos subjetivos que elas, por definição, não abarcam. (p. 23-24).

Essa trama provoca um grande dilema no Jornalismo, pois o jornal (por meio das diferentes mídias) é o primeiro veículo a dar as notícias e está sempre às voltas com as novidades, com o que acontece pelo mundo. Por outro lado, tem que ser veloz e noticiar os fatos da melhor maneira possível, tudo tem que estar na medida, não pode ser rebuscado demais para que os interlocutores (sejam eles: ouvintes, telespectadores, leitores, internautas, etc.) consigam entender, não pode ser chulo demais porque não agradaria a todos. Alguns jornalistas se vêem obrigados, profissionalmente, a escrever sobre assuntos que não dominam, daí surgem algumas gafes e até erros grosseiros no final do dia. 


\subsection{1 - História da Folha de S. Paulo (FSP)}

\section{FOLHA DE S.PAULO \\ DOMINGO, 23 DE MAIO DE 2010}

FOLHA DE S.PAULO 2006

FOLHA DE S.PAULO 1996

FOLHA DE S.PAULO $\quad 1990$

FOLHA DE S.PAULO 1983

FOLHA DE S. PAULO 1970

FOLHA DE S.PAULO 1968

FOLHA DE S. PAULO $\quad 1960$

OUHA DA TARD: 1949

Folha da Noife 1931

Totha cha Manta 1925

Fothadadoite 1921

Fig. 1 Os vários logotipos do Grupo Folha da Manhã desde 1921

(Caderno Especial- “Novíssima!”, 23/05/2010).

O jornal FSP foi fundado em 21 de fevereiro de 1922 sob o nome de Folha da Noite. Em julho de 1925, surgiu a Folha da Manhã, uma versão matutina do jornal. Quanto ao surgimento deste último, um fato muito curioso, segundo Paschoal (2007), é que havia uma charge estampada na primeira página do jornal e embaixo dela na primeira edição da Folha da Manhã vinha escrito “-Oh! Senhores! Agora o barulho é pela manhã também?!!!”. Tal frase se torna significativa se levarmos em conta que já estava em circulação o jornal Folha da Noite fazendo uma alusão sobre a irreverência do antigo jornal que poderia ser lido pelas manhãs também. Paulo Duarte disse ter tido problemas com a rotativa para que houvesse a impressão dos primeiros jornais, no entanto, “(...) antes da madrugada, com grande alívio nosso, os primeiros números da Folha da Manhã começaram a ser lançados pela máquina (...)” (p. 32). 


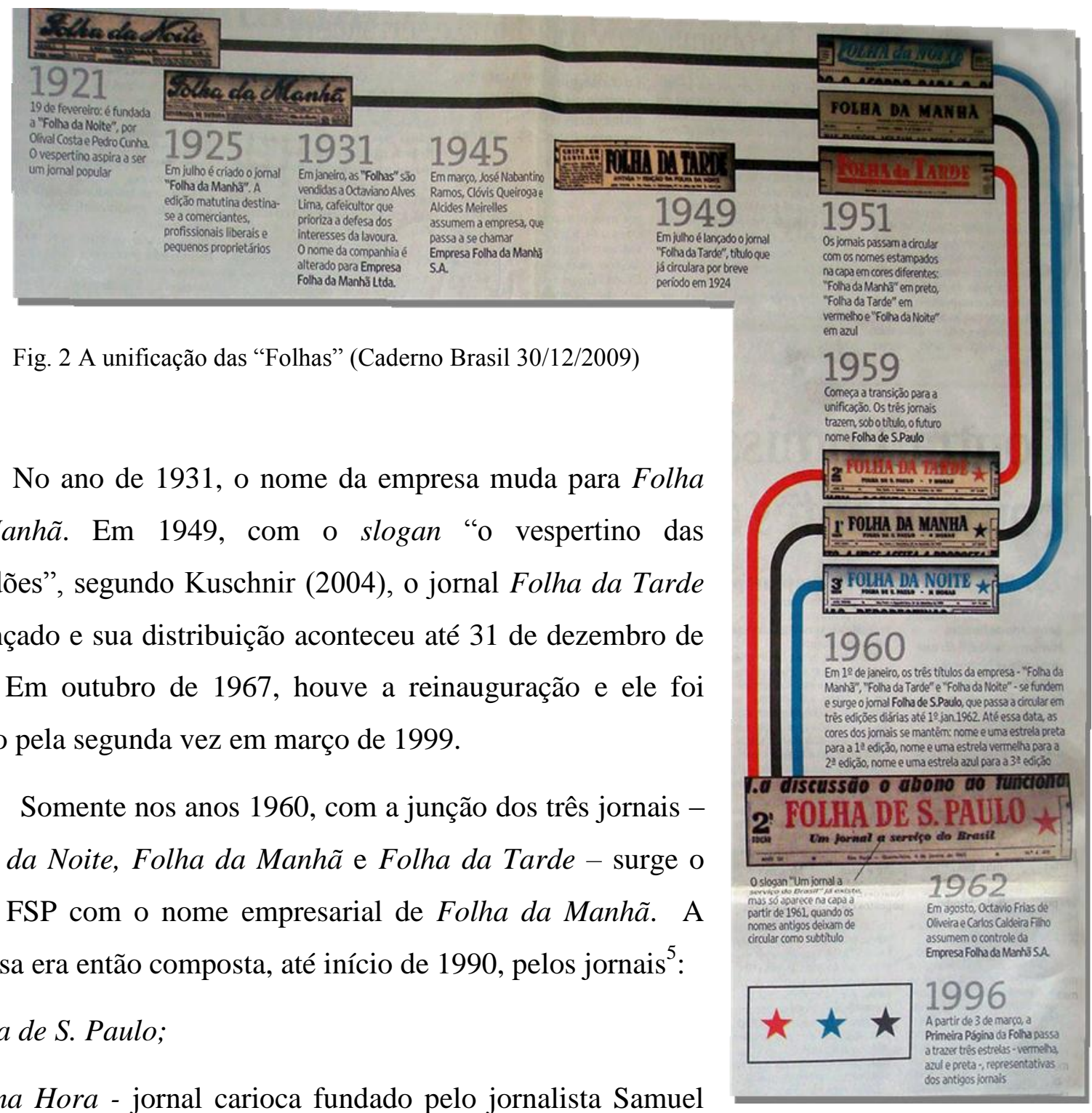

*Última Hora - jornal carioca fundado pelo jornalista Samuel

Wainer em 12 de junho de 1951. Foi o único jornal brasileiro a ser publicado simultaneamente em sete cidades. São elas: Rio de Janeiro, São Paulo, Niterói, Belo Horizonte, Curitiba, Porto Alegre e Recife. O jornal foi vendido à Empresa Folha da Manhã em 1971, e no ano de 1979 o jornal foi vendido para Ari Carvalho;

*Notícias Populares- surgiu em 15 de outubro de 1963 e foi extinto em 20 de janeiro de 2001;

*Cidade de Santos - surgiu em 14 de julho de 1966 e teve seu fim em 15 de setembro de 1987 ;

\footnotetext{
${ }^{5}$ Dados retirados do site: www.arquivo estado.sp.gov.br às 19:35 de 31/07/2010
} 
*Folha da Tarde. No final dos anos 1990, esta última Folha se extinguiu e no lugar dela foi lançado o jornal Agora São Paulo, em circulação até hoje.

Segundo Kuschnir (2004), o Grupo Folha mostra sua história e constituição de forma um pouco deturpada, pois para a empresa Folha da Manhã houve três etapas distintas em sua formação: "Entre 1962 e 1967, houve uma reorganização financeiroadministrativa e tecnológica; entre 1968 e 1974, ocorreu uma 'revolução tecnológica'; e entre 1974 e 1981, definiu-se um projeto político-cultural.” (p. 220). No entanto, a autora questiona essa divisão do jornalismo da Folha, pois ela se apresenta totalmente desvinculada dos aspectos político-sociais em constante transformação.

No ano de 1967, segundo a autora, houve o investimento em tecnologia chamada offset, considerada de ponta na época e que tornou a Folha da Tarde o primeiro jornal de São Paulo a ter fotos coloridas em suas páginas. Houve, também, o aumento de frotas para que houvesse maior agilidade na entrega dos jornais. Tudo isso culminou na transformação da FSP no jornal mais lido no interior, segundo pesquisas do Ibope. O que nos leva a pensar que a parceria entre Octávio Frias de Oliveira e Carlos Caldeira Filho foi de grande sucesso. Ao longo dos anos, a empresa cresceu e se tornou a pioneira em tecnologia e em sistema de crítica interna, como o ombdusman ${ }^{6}$.

\footnotetext{
6 "Ombudsman é uma palavra sueca que significa representante do cidadão. Designa, nos países escandinavos, o ouvidor-geral -função pública criada para canalizar problemas e reclamações da população. Na imprensa, o termo é utilizado para designar o representante dos leitores dentro de um jornal”. A FSP foi a pioneira, em 24 de setembro de 1989, a estabelecer essa função dentro do jornal. (Disponível em: http://www1.folha.uol.com.br/folha/ombudsman/cargo.shtml, às 19 h33 de 4/08/2010)
} 


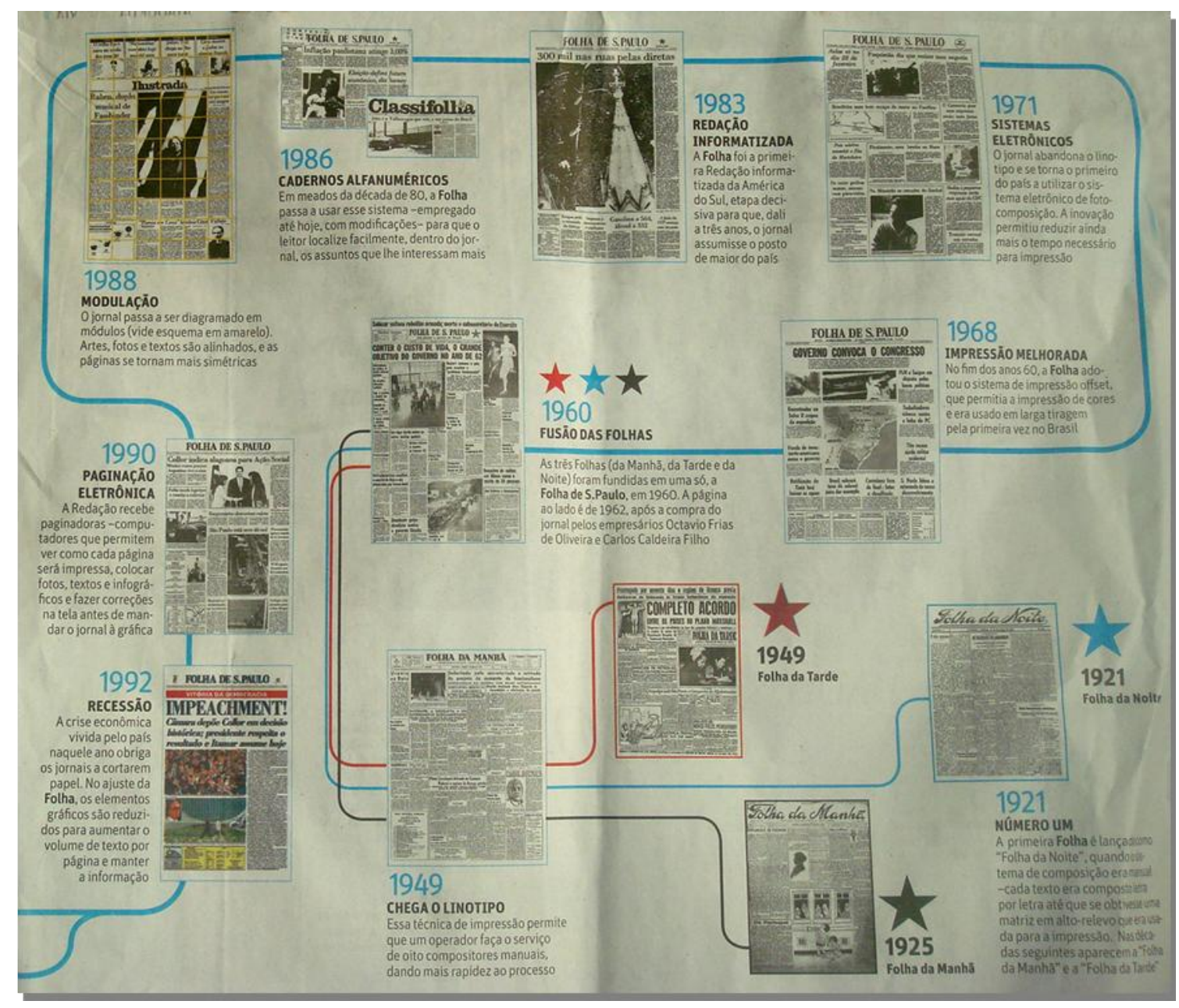

Fig. 3 História Visual da Folha (Caderno Especial- “Novíssima!”, 23/05/2010)

No livro Trajetória de Octávio Frias de Oliveira de Engel Paschoal, publicado em 2007, Octávio Frias de Oliveira Filho afirma que a abertura da economia brasileira, na década de 1970, impulsionou seu pai a se preocupar com a qualidade editorial do jornal, com a criticidade e com os grandes anunciantes. Dessa forma, a FSP se tornou um jornal:

(...) mais atuante, mais crítico, mais incômodo. O jornal passou a ter opinião definida - não apenas a sua própria, como era habitual, mas opiniões de todo um elenco de colunistas e colaboradores, divergentes entre si. Esse traço de pluralidade radical, que se tornou marca registrada da Folha e um valor cultivado (ao menos nominalmente) pela imprensa brasileira como um todo, não tenho dúvidas em atribuílo à influência direta de meu pai.... A Folha passou a ser conhecida no mundo da mídia, como jornal, aguerrido, polêmico, sem 'listasnegras', assuntos tabu ou 'amigos da casa'. Um afastamento ostensivo de governos, grupos de poder e partidos políticos passou a dar a tônica política do jornal, ilustrada numa frase que meu pai costuma repetir: 'Do governo só queremos distância'. (p. 14). 
Por outro lado, Kuschnir (2004) diz que a FSP teve problemas com os militares, chegando até a extinguir os editoriais e Octavio Frias se demitiu de todos os cargos que ocupava. Isso ocorreu como uma espécie de protesto do jornal perante a prisão do jornalista Lourenço Diaféria que escrevera uma crônica, intitulada Herói. Morto. Nós, que foi publicada em $1^{\circ}$ de setembro de 1977, referente à Semana da Pátria e que foi considerada ofensiva pelo general Sylvio Frota, então ministro do Exército, por tratar de maneira desrespeitosa, segundo o próprio general, a figura de Duque de Caxias, patrono do Exército.

Levando em conta os acontecimentos históricos, uma das bases do jornal FSP é primar pela "objetividade". Nesse veículo de comunicação, "o texto deve ser de fácil compreensão, tornando a notícia legível e compreensível, pois um jornal de grande circulação dirige-se a diversos grupos sociais". ${ }^{7}$

A partir dessa citação, fica claro que a empresa Folha da Manhã deseja atingir o maior escopo possível de leitores, público este que não é elitizado, mas heterogêneo. Isso aparece em mais um excerto do Projeto Editorial do jornal como podemos observar:

\footnotetext{
Em meio à balbúrdia informativa, a utilidade dos jornais crescerá se eles conseguirem não apenas organizar a informação inespecífica, aquela que potencialmente interessa a toda pessoa alfabetizada, como também torná-la mais compreensível em seus nexos e articulações, exatamente para garantir seu trânsito em meio à heterogeneidade de um público fragmentário e dispersivo.
}

Outra questão que se poderia levantar em relação ao que o grupo Folha toma como verdade é a conceituação de seu público-alvo, para quem esse jornal é dirigido. $\mathrm{E}$ é isso que vemos na propaganda no site da própria FSP, mesmo sabendo que o preço do jornal não é tão acessível para a classe mais popular da sociedade paulistana. E que alguns cadernos, como Cotidiano ou a antiga revista da Folha - que hoje leva o nome de Revista São Paulo desde a segunda semana de junho de 2010 - que vem como suplemento uma vez por semana, destacam lugares nem sempre acessíveis a todas as classes sociais.

Projeto Editorial da Folha de S. Paulo, 1997. Disponível em: http://www1.folha.uol.com.br/folha/circulo/proj_edi_abertura.htm. 12/12/2009 


\title{
0 jornal mais influente para
} as classes A e B é aquele que nunca se deixa influenciar.

Folha. 0 jornal escolhido pelas classes A e B, sem nunca privilegiar classe nenhuma.

CLIQUEE SAIBA MAIS.

Fig. 4 Sobre o público alvo do jornal Folha de S. Paulo

Fonte: Disponível em: http://publicidade.folha.com.br/Publicidade/AB/index.html.

Acesso em: 19/07/2010.

Para que haja um jornal que se aproxime dos leitores e que, ao mesmo tempo, consiga manter a sua objetividade e diretrizes, empregam-se pesquisas de opinião. Tais pesquisas, apesar de serem consideradas um sistema aparentemente concreto, apresentam problemas, conforme podemos verificar no excerto a seguir do mesmo Projeto Editorial.

\begin{abstract}
Pesquisas de opinião possibilitam conhecer um pouco melhor as necessidades do público e aproximar a pauta do jornal e a vivência concreta do leitor. Mas, não substituem o discernimento necessário para detectar a ocasião jornalística nos fatos que reúnam o geral e o específico, em que um processo relevante ou emergente apareça entrelaçado com sua manifestação mais sintomática e humana. Essa preocupação deveria nortear a elaboração do jornal, da pauta à edição.
\end{abstract}

Nesse emaranhado de problemas e paradoxos, há que se problematizar também o preparo e o conhecimento do jornalista ao escrever uma determinada notícia, pois não há como o jornalista ser um especialista de todas as áreas do conhecimento, não há como conhecer absolutamente tudo, desde engenharia de software até a última tendência da moda em Milão. Para isso, segundo Rossi (1994), a FSP: 
(...) iniciou um processo de seminários internos que busca dar mais base a seus profissionais. Convida especialistas para falarem sobre temas de sua especialidade, para repórteres e redatores da editoria que cuidam desse assunto. O trágico é que o interesse por esses seminários, raramente tem sido grande. O que, ao menos em tese, demonstra que nem todas as culpas pelas lacunas no trabalho dos jornalistas podem ser atribuídas às empresas. (p. 39).

Por meio das notícias, o jornalista reflete e avisa a sociedade sobre determinado tema revelando também a evolução lingüística, isto é, a constituição e a mudança da língua portuguesa nos textos por ele produzidos. A seguir abordaremos alguns aspectos do Manual da Redação: Folha de S. Paulo, analisando se há concordância entre o que é dito no manual e o que acontece efetivamente no cotidiano da redação das notícias.

\section{6 - Manual da Redação: Folha de S. Paulo (MRFSP)}

O MRFSP já está na $14^{\circ}$ edição, o que demonstra a sua força e a sua proporcional vendagem. Nesse sentido, o que faz um jornal ser capaz de ampliar seus negócios, lançando um livro de normas e estilos para redação e este se tornar conceituado a partir da alta legitimidade e da desejável "neutralidade do jornal" em si?

Quanto à organização, o manual é dividido em quatro capítulos: "Projeto Folha", "Procedimentos", "Padronização e estilo" e "Estrutura da Folha". Para este trabalho, daremos mais atenção aos dois primeiros capítulos; o primeiro por se tratar da base filosófica da constituição do jornal como instituição social e o público-alvo a que se quer chegar dentro dessa sociedade; e o segundo por estar relacionado às normas, que devem ou deveriam ser seguidas pelos jornalistas no dia a dia do jornal, e que verificaremos, ao longo dessa dissertação, se efetivamente foram respeitadas.

Quanto ao Projeto Editorial Folha, importa destacar, já em suas primeiras linhas, que surgiu e foi desenvolvido "desde os meados da década de 70, com o objetivo de produzir um jornalismo crítico, moderno, pluralista e apartidário” (p. 10, grifo nosso). A grande questão que fica é como fazer um texto ao mesmo tempo crítico e apartidário? Criticar já não implica uma tomada de posição? Já foi dito na introdução deste trabalho que a neutralidade na língua não existe, uma simples prosódia diferenciada, ou até mesmo a escolha do léxico, mais ou menos rebuscada, pode mudar 
o sentido de um texto. Como podemos ter um jornalismo crítico e ao mesmo tempo apartidário se o enunciador precisa fazer uma escolha ideológica?

Em relação ao tema neutralidade versus tomada de opinião, pela Lei da Imprensa, instituída Lei no 5.250, de 9 de fevereiro de 1967 e Atualizada até janeiro de 2000, no CAPÍTULO IV, intitulado DO DIREITO DE RESPOSTA, temos o Artigo 30 que disserta sobre os direitos dos que foram ofendidos na mídia:

Art. 30. O direito de resposta consiste:

I - na publicação da resposta ou retificação do ofendido, no mesmo jornal ou periódico, no mesmo lugar, em caracteres tipográficos idênticos ao escrito que lhe deu causa, e em edição e dia normais; $\S 1^{\circ}$ A resposta ou pedido de retificação deve:

a) no caso de jornal ou periódico, ter dimensão igual à do escrito incriminado, garantido o mínimo de cem linhas; (...)

Na busca da imparcialidade, a FSP criou o "Outro Lado", espaço destinado a mostrar a outra versão dos fatos expostos na matéria imediatamente acima na página do jornal. É de grande valia para composição de análise deste trabalho o "Outro lado" da FSP, pois a incidência de discurso direto e indireto nessa seção é muito marcada e as convergências ou divergências de opiniões e as diferentes vozes estão explicitadas nos textos apresentados neste espaço. A partir do MRFSP temos:

\footnotetext{
Quando o repórter dispõe de uma informação que possa ser considerada prejudicial a uma pessoa ou entidade, é obrigatório que ele ouça ou publique com destaque proporcional a versão da parte atingida - esse procedimento na Folha, é chamado de 'ouvir o outro lado'. (p. 26).
}

Mas o que já se pode adiantar é que não existe uma equidade de palavras entre o corpo do texto e a seção "Outro lado", isto é, não se dá o mesmo espaço de linhas na página do jornal para que ambos os interessados argumentem e exponham seus pontos de vistas dentro da notícia, o que pode acarretar aí certa manipulação por parte da imprensa devido aos espaços díspares dado às partes interessadas.

Segundo o MRFSP, o "Outro Lado" serve como um termômetro para que o jornalista não cometa erros e/ou injustiças, a partir de uma conclusão precipitada e parcial: 
Cruzar informações e ouvir o outro lado permite, ainda, que o jornalista não endosse versões interessadas, que visem a manipulação da opinião pública, nem o erro que possa ser cometido por pessoas, instituições, empresas ou grupos. É sempre importante perguntar-se a quem uma notícia vai interessar, a quem ela traz prejuízos e quem dela se beneficia. São perguntas que ajudam a esclarecer o jogo de interesses por detrás dos fatos. (p. 27).

Já no excerto a seguir, do Projeto Editorial, a função do "Outro lado" na FSP e a questão de uma atitude apartidária versus comodista são apresentadas da seguinte forma:

O Pluralismo, apequenado muitas, vezes na auscultação meramente formal do 'outro lado' da notícia, deveria renovar-se na busca de uma compreensão mais autêntica das várias facetas implicadas no episódio jornalístico. Mesmo a atitude apartidária, que veda alinhamentos automáticos e obriga a um tratamento distanciado em relação às correntes de interesse que atua sobre os fatos, não pode servir de álibi para uma neutralidade acomodada, quando não satisfeita em hostilizar por hostilizar. (p.18).

Outro fator que devemos levar em consideração não é somente ouvir o outro lado, mas tão importante quanto, para que uma notícia tenha um caráter confiável, em certa medida, é a classificação das fontes de informação. A FSP divide tais fontes em quatro tipos, que são elencadas e elucidadas da seguinte maneira:

1) Fonte tipo zero - Escrita com tradição de exatidão, ou gravada sem deixar margem à dúvida: enciclopédias renomadas, documentos emitidos por instituições com credibilidade, videoteipes. Em geral a fonte de tipo zero prescinde de cruzamento. Para não repetir erros já publicados, evite ter um periódico do tipo jornal ou revista como única fonte para uma informação.

2) Fonte tipo um - É a mais confiável nos casos que a fonte é uma pessoa. A fonte de tipo um tem histórico de confiabilidade - as informações que passa sempre se mostram corretas. Fala com conhecimento de causa, está muito próximo do fato que relata e não tem interesses imediatos na sua divulgação. Embora o cruzamento de informações seja sempre recomendável, a Folha admite que informações vindas de uma fonte tipo um sejam publicadas sem checagem com outra fonte.

3) Fonte tipo dois - A de menor confiabilidade. É bem informada, mas tem interesses (políticos, econômicos etc.) que tornam suas informações nitidamente menos confiáveis.

4) Fonte tipo três - Na Folha, há dois caminhos para a informação de fonte tipo três: funcionar como simples ponto de partida para o trabalho jornalístico ou, na impossibilidade de cruzamento com outras fontes, ser publicada em coluna de bastidores, com a indicação explícita de que ainda se trata de rumor, informação não confirmada. (p.38).

Quanto à seletividade das várias notícias que chegam ao jornal Folha de S. Paulo, segundo o próprio MRFSP, selecionar é priorizar assuntos em detrimento de 
outros, de modo que a equipe é que julga o que há de mais relevante na dada edição, ou o que afeta diretamente a sociedade, economia, política etc., ou seja, a história de uma certa comunidade.

Isso nos leva a pensar qual seria o critério dessa seletividade: seria apenas com relação ao que a equipe editorial acredita ser mais pertinente, ou também teria uma grande relevância o público-alvo que o jornal busca atingir? Já foi dito na introdução deste trabalho que a maior parte do público-alvo da Folha de S. Paulo é das classes A e B.

Cabe destacar que, segundo Melo (1979), em países menos favorecidos economicamente, em que há um nível cultural mais baixo, “a imprensa assume o papel de um meio de comunicação de elite, se comparado aos outros meios de comunicação social” (p. 29). Há também que se levar em consideração que a maior parte dos leitores não chega a ler o jornal inteiro, todas as notícias de todos os cadernos contidos no jornal. Por isso, em Procedimentos o MRFSP afirma que é preciso presumir "que quem irá ler o texto é um grupo heterogêneo de pessoas, não necessariamente informado sobre todos os aspectos da notícia" (p. 23).

Quanto à questão de recolhimento de testemunhos sobre o fato ocorrido, no mesmo capítulo, aparece uma nova orientação denominada pelos autores de "dica" que trata da quantidade de fontes. Conforme o MRFSP, quanto maior o número de fontes, melhor é para a composição e para a redação da notícia, como podemos verificar no trecho em que se diz: "Um maior número de nexos surgirá entre os fatos quanto maior for também o número de fontes de que se dispõe, sejam elas pessoas ou documentos. Quanto mais numerosas, as fontes, mais ricas as reportagens" (p. 23).

Além das fontes e do público-leitor, outra questão a ser considerada é a seleção das notícias, pois, no mundo globalizado em que a informação muda a cada segundo devido ao uso da internet, fica difícil noticiar tudo o que acontece e, assim, eleger qual notícia deverá entrar ou não na edição de um jornal. Talvez seja por isso que um dos objetivos da FSP, segundo o projeto editorial de 1997, é ser:

um jornal que faz frente a uma exigência qualitativa muito superior à do passado, refinando sua capacidade de selecionar, didatizar e analisar. É recomendável que a gama de assuntos a serem cobertos até mesmo se reduzam em alguma medida, desde que em contrapartida sua seleção seja mais pertinente, e o tratamento que receberem, mais compreensivo. 
Nesse projeto editorial, especificamente no tópico intitulado Seleção de fatos e compreensão de seus nexos num texto mais livre ${ }^{8}$, temos as prerrogativas de um grande jornal para a construção de uma notícia, em que se busca clareza, objetividade e credibilidade, sempre levando em conta a confiança do leitor para com o jornal, conforme atesta o trecho abaixo:

Trata-se, porém, de política a ser administrada com parcimônia e cautela, seja para que não se perca a base objetiva de informação, seja para que o leitor não fique à mercê dos caprichos da subjetividade de quem está ali para, antes de mais nada, informar com exatidão. A um texto noticioso mais flexível deve corresponder um domínio superior do idioma, bem como redobrada vigilância quanto à verificação prévia das informações, à precisão e inteireza dos relatos, à sustentação técnica das análises e à isenção necessária para assegurar o acesso do leitor aos diferentes pontos de vista suscitados pelos fatos. (grifo nosso)

Existem ainda na FSP seis critérios para classificar a importância de uma notícia, o que definirá se ela vai ser publicada no jornal do dia ou não. Relacionamos, a seguir, quais são esses critérios pré-estabelecidos e suas funções:

1) Ineditismo (a notícia inédita é mais importante do que a já publicada)

2) Improbabilidade (a notícia menos provável é mais importante do que a esperada)

3) Interesse (quanto mais pessoas possam ter sua vida afetada pela notícia, mais importante ela é)

4) Apelo (quanto maior a curiosidade que a notícia possa despertar, mais importante ela é)

5) Empatia (quanto mais pessoas puderem se identificar com o personagem e a situação da notícia, mais importante ela é)

6) Proximidade (quanto maior a proximidade geográfica entre o fato gerador da notícia e o leitor, mais importante ela é). (p. 44, grifos nossos).

Não só esses critérios devem ser observados na produção de textos jornalísticos. Para alguns estudiosos do tema, como Serva (2005), a edição é um fantasma subjetivo que ronda a publicação de um jornal. Ela é a organização de informações que um grupo de editores julga ser de maior interesse público, como se o interesse do leitor pudesse ser totalmente compreendido.

\footnotetext{
${ }^{8}$ Disponível em: http://www1.folha.uol.com.br/folha/circulo/projeto_editorial_texto_livre.htm.
} 
Considerando o que foi apresentado até aqui, perguntamos qual seria o verdadeiro papel do jornal impresso hoje em dia? E no passado? Essa é uma importante questão que buscaremos responder no capítulo a seguir. 
"Notícia - Puro registro dos fatos, sem opinião.

A exatidão é o elemento-chave da notícia, mas vários fatos descritos com exatidão podem ser justapostas de maneira tendenciosa. Suprimir ou inserir uma informação no texto pode alterar o significado da notícia. Não use desses expedientes". (- Manual da Redação Folha de S. Paulo p. 90). 


\section{CAPÍTULO 2: A ANÁLISE CRÍTICA DO DISCURSO: 0 GÊNERO NOTÍCIA E A POLIFONIA}

\section{1 - A Análise do Discurso Crítica}

A teoria em que este estudo se embasa é a Análise Crítica do Discurso (doravante ACD). A ACD teve como um dos principais fundadores Norman Fairclough, nascido em 1941, professor emérito da Universidade de Lancaster, Inglaterra. O pesquisador defende que a linguagem é parte integrante e inerente à vida social. Tendo em vista tal afirmação, é de suma importância uma teoria que abarque e entrelace o social com a linguagem. Os atores sociais e os grupos de atores sociais estão diretamente ligados à produção e interação social aos quais se inserem. O discurso por essa abordagem é tratado com uma prática social, desse modo, discurso e sociedade estariam totalmente imbricados.

O primeiro a se valer do termo Análise Crítica do Discurso foi Norman Faiclough, em um artigo que publicou em 1985. No entanto, a teoria pode ser vista como uma continuidade da Linguística Crítica da década de 1970. A ACD surgiu para superar a produtividade e ampliar sua divulgação. Fairclough contribui para ACD na medida em que criou um novo método de estudo do discurso e elucidou para os especialistas das mídias o quanto a Linguística é importante para o desenvolvimento desse setor.

Assim, a ACD não estaria somente ligada ao aspecto formal e estrutural da língua em seu plano interno, mas intimamente relacionada à interação do texto com a sociedade e o momento histórico em que se situa. As pesquisadoras Resende e Ramalho (2006) dizem não ser o interior do sistema lingüístico o foco de trabalho de um pesquisador que siga a linha da ACD:

(...) somente o conceito funcionalista de discurso (...) uma vez que o foco de interesse não é apenas a interioridade dos sistemas linguísticos mas, sobretudo, a investigação de como esses sistemas funcionam na representação de eventos, na construção de relações sociais, na estruturação, reafirmação e contestação de hegemonias no discurso (p. $11)$.

Como vimos no excerto anterior, diferentemente da ACD, a Análise do Discurso no início estava centrada na descrição de estrutura dos textos e da conversação ou em 
processos psicológicos do discurso. O que diferencia a teoria tradicional (Análise do Discurso) da teoria crítica (Análise Crítica do Discurso) é que a última não é apenas descritiva, nem tão somente teoriza problemas sociais, mas sim participa ativamente de processos de mudança.

Segundo Lima (2009), a ACD tem uma visão particular do poder que no "momento sócio-histórico em que a comunicação assume o centro do modo de produção no sistema capitalista, consiste em influenciar os outros por meio de persuasão, (...) canais para influenciar as classes dominadas.” (p. 59) e que constroem uma hegemonia em favor aos dominantes, mantendo-os no poder.

Outra questão que a ACD valoriza é que a Crítica tem que ser provida e estudada para que haja um favorecimento e uma mudança social para aquela parcela da população menos favorecida. Há uma intersecção entre a linguagem e a prática social, dessa maneira o discurso é considerado por Resende e Ramalho (2006) como sendo:

(...) um modo de ação historicamente situado que tanto é constituído socialmente como também é constituído de identidades sociais, relações sociais e sistema de conhecimento e crença. Nisso consiste a dialética entre discurso e sociedade: o discurso é moldado pela estrutura social, mas é também constitutivo da estrutura social. (p. 27).

De acordo com o quadro a seguir, o texto (vocabulário, gramática, coesão e estrutura social) estaria inserido na prática discursiva (produção, distribuição, consumo, contexto, coerência, intertextualidade) e a prática textual (ideologia, sentido, pressuposições etc.). Dessa maneira, o texto estaria dentro de seus aspectos formais e poderia mostrar, às vezes, de uma forma mais velada ou não as práticas discursivas e sociais.

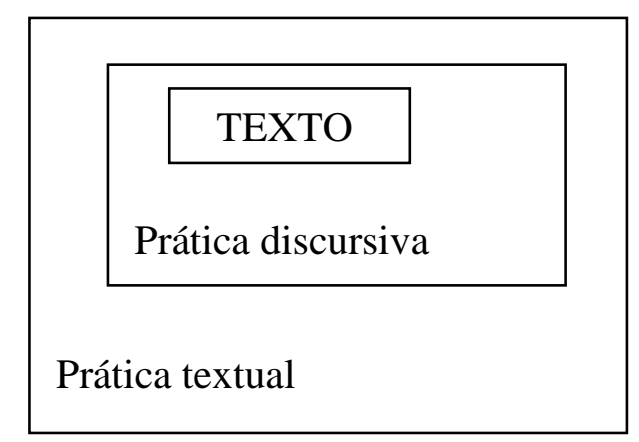

Quadro teórico I: Concepção tridimensional do discurso em Fairclough 
Um conceito importante para a ACD é o da reflexividade em que os sujeitos formam ativamente a sua auto-identidade conforme o seu papel dentro da sociedade. Dessa forma, constitui-se a noção de ator social como aquele que se molda pelo discurso, mas que ao mesmo tempo pode ser contestado por ele. E as práticas sociais estariam ligadas aos atos realizados em determinados contextos diferentes e estariam em conformidade com o aceitável dentro daquela sociedade. A ACD sempre vai trabalhar no sentido de trazer à tona uma relação de poder, para que a partir de uma exposição haja um movimento de defesa daqueles que antes eram dominados.

Para Fairclough (2001), a hegemonia que seria o domínio de um grupo de pessoas sobre os demais, estaria totalmente ligada à prática discursiva, na medida em que é a partir do discurso que a hegemonia se consolida produzindo e reproduzindo, contestando e transformando-o. Para Ramalho e Resende (2006), “(...) o próprio discurso apresenta-se como uma esfera de hegemonia, sendo que a hegemonia de um grupo é dependente, em parte, de sua capacidade de gerar práticas discursivas e ordens de discurso que a sustentem" (p. 44).

Mais do que a hegemonia, a ideologia é definida por Fairclough (2001) como sendo “(...) significações/construções da realidade que são construídas em várias dimensões das formas/sentidos das práticas discursivas e que contribuem para a produção. A reprodução ou a transformação das relações de dominação" (p. 117).

A ACD também é influenciada pelos conceitos de Bakhtin (1997), pois este autor defende que a grande gama diversificada da produção da linguagem em uma interação social forma e constituí um todo, que a primeira vista pode nos parecer caótico e desordenado; no entanto isso ocorre devido à produção de gêneros diferenciados, que seriam "tipos de enunciados relativamente estáveis do ponto de vista temático, composicional e estilístico, que refletem a esfera em que são gerados" (p. 284).

O conceito de gênero na ACD está ligado aos grupos e práticas sociais, estes grupos se utilizam de gêneros discursivos particulares que marcam e, de certa forma, caracterizam seu grupo. Esses enunciadores articulam discursos e estilos mais ou menos estáveis em um determinado contexto histórico e social. Fairclough também defende a ideia de que o gênero não deve ser analisado como algo fixo e acabado, e sim deveria se levar em conta a mutabilidade do gênero e a criatividade do analista para não reduzir a sua análise. 
A intertextualidade é um fator importante da linguagem, e podemos observar seu valor a partir dos estudos de Bakhtin (2002), ao defender que os textos são diálogos em dois sentidos, e conforme destacam Resende e Ramalho (2006):

A intertextualidade é uma categoria de análise muito complexa e potencialmente fértil. Bakhtin (2002) enfatizou a dialogicidade da linguagem, postulando que textos são dialógicos em dois sentidos: primeiro, mesmo os textos aparentemente monológicos, como textos escritos, participam de uma cadeia dialógica, no sentido de que respondem a outros textos e antecipam respostas; segundo, o discurso é internamente dialógico porque é polifônico, todo texto articula diversas vozes (p. 65).

Mais adiante as autoras fazem uma ligação entre intertextualidade e discurso citado, sendo os discursos direto e indireto fortes indícios desses dois fenômenos linguísticos.

(...) a intertextualidade é a combinação da voz de quem pronuncia um enunciado com outras vozes. Fairclough (2003, p. 39) adota uma visão ampla de intertextualidade, extrapolando seu sentido mais evidente: “a presença de elementos atualizados de outros textos em um texto- as citações". Para relatar um discurso, pode-se não apenas citar em discurso direto, mas também parafrasear, resumir, ecoar em discurso indireto. O discurso relatado atribui o dito a seu autor, mas a incorporação de elementos de outros textos também pode ser feita sem atribuição explícita como, por exemplo, na paráfrase. Assim, a intertextualidade cobre uma gama diversa de possibilidades. (p. 65).

\subsubsection{Discurso direto e Discurso indireto}

O discurso direto é definido como sendo a citação, pretensamente, fiel do dito e que apresenta marcas de citação como: aspas ou travessão. Já o discurso indireto pode ser definido como uma adaptação do dito, isto é, o enunciador pode parafrasear ou resumir aquilo que foi dito, sem marcar com aspas ou travessão e mesmo sem a exatidão dos termos empregados pelo outro interlocutor. Segundo Resende e Ramalho (2006), "não é incomum se utilizarem de marcas de citação quando, na verdade, não se 
atualizam as palavras exatas do discurso relatado (por exemplo, na mídia impressa" (p.66).

O tema e o eixo central desta dissertação estão embasados na definição das mesmas autoras citadas anteriormente com relação discurso direto e indireto apresentada no excerto anterior, mas cabe destacar que o assunto desta pesquisa gira em torno das funções do discurso direto e do discurso indireto na mídia impresa. O excerto, a seguir, expressa de forma verdadeira alguns questionamentos deste trabalho:

A representação do discurso não é uma mera questão gramatical, ao contrário, é um processo ideológico cuja relevância deve ser considerada. Analisar em textos quais vozes são representadas em discurso direto, quais são representadas em discurso indireto e quais as consequências disso para a valorização ou depreciação do que foi dito e daqueles(as) que pronunciaram os discursos relatados no texto pode lançar luz sobre questões de poder no uso da linguagem. (p. 67)

Para Bakhtin a linguagem como um todo é polifônica e dialógica, pois até mesmo em textos escritos existe uma cadeia dialógica em que o texto remete a algo que já foi dito antes ou a algo que ainda será proferido. Há, dessa forma, um caráter responsivo nos textos em seus mais variados gêneros. O que nos remete ao conceito de polifonia também em que há a retomada de realizadas anteriormente e, por outro lado se antecipa vozes posteriores.

Já relatamos anteriormente que investigaremos na análise tanto a notícia em si como a retranca chamada "Outro lado" pela FSP. Esses "combates" entre opiniões antagônicas e que se mostram em um texto algumas vezes mais veladas e em outras não, tal "seção" na FSP existe como forma de mostrar para o leitor sua imparcialidade e sua veracidade, como já foi levantado no parágrafo anterior. Por isso, podemos dizer que, de acordo com Resende e Ramalho (2006) quando os discursos “(...) entram em competição em um texto, é comum haver um discurso 'protagonista' e um discurso 'antagonista'. Nesse caso, a articulação serve a propósito de negação de um discurso em nome da afirmação do outro" (p. 71).

A escolha lexical também é um item para se pensar no referencial apontado pelo enunciador, pois - ao escrever "Professores fazem tumulto na Paulista" ao invés de "Professores fazem greve na Paulista" ou até mesmo "Professores reivindicam seus diretos por meio de greve" - temos pontos de vista distintos do primeiro apresentado 
pelo enunciador, perpassando para o leitor a posição assumida pelo enunciador diante de uma greve do corpo docente. Dizer que existe uma neutralidade e uma objetividade totalitária é subverter a ordem da própria linguagem, pois ela é dinâmica e aberta e pode ser construída das mais diferentes maneiras, criando efeitos de sentido diversos.

\subsubsection{Atores sociais}

Abordaremos o conceito de atores sociais que foi somente elencado no tópico 2.1 A Análise Crítica do Discurso, pois ele é importante no processo de análise linguístico da ACD a ser destacado e desenvolvido por Van Leeuwen (1997). Este conceito arrola sobre as maneiras como atores sociais são revelados nos textos e podem indicar posições ideológicas divergentes ou convergentes. Alguns atores, segundo Resende e Ramalho (2006) “(...) podem ter sua agência ofuscada ou enfatizada em representações, podem ser representados por suas atividades e enunciados ou, ainda, podem ser referidos de modo que presume julgamento acerca do que são e do que fazem" (p.72).

Dessa maneira Van Leeuwen (1997) chega a algumas conclusões de que na imprensa as personagens sem nome estão ligadas apenas a papéis fugazes e estritamente funcionais. Por outro lado, representações em que os nomes próprios dos agentes são citados mostram uma valorização do mesmo. Já a impersonalização por autonomização é o processo de substituição de uma personalidade humana; metonímia, como por exemplo, ao citar alguma medida tomada pelo Ministro da Educação, cita-se apenas o documento expedido pelo ministro ao invés de indicar a autoria de quem o proferiu; dessa maneira, quer se dar um tom mais objetivo e imparcial à notícia tornando-a mais verdadeira. Assim temos que como afirmam Resende e Ramalho (2006): “(...) os discursos constituem parte do recurso utilizado por atores sociais para se relacionarem cooperando, competindo, dominando.” (p.71).

Van Leeuwen (1997) também afirma que a inclusão ou a exclusão de atores sociais estão ligadas aos interesses e propósitos do enunciador (jornalista que escrever a notícia) em relação aos seus enunciatários (leitores ou público-alvo do jornal). Tal processo também pode ocorrer de maneira mais velada como, por exemplo, deixar atores sociais em segundo plano como vemos no excerto a seguir: 
No caso de colocar em segundo plano, a exclusão é menos radical: os actores sociais excluídos podem não ser mencionados em relação a uma dada atividade, mas são mencionados algures no texto, e nós conseguimos inferir com alguma (embora nunca total) certeza quem eles são. Eles não estão tanto excluídos, mas sim poucos visíveis, empurrados para o segundo plano. (p. 181).

Colocar um ator social em segundo plano, como vimos no excerto anterior, é diferente de fazer uma supressão desse agente, já que esta consiste em um apagamento do agente da passiva. Como no exemplo a seguir, da manchete do nosso corpus, notícia 24, publicada no dia 27 de abril de 2004, no caderno Cotidiano da FSP:

São atribuídos à comissão que analisa obras de ciências desde erros conceituais até críticas que não procedem

Autores criticam avaliação de livros didáticos

Em um primeiro momento, é suprimido quem acusou sobre os erros à comissão de avaliação de livros didáticos, mas logo em seguida é revelado o grupo de atores sociais (autores de livros didáticos que foram reprovados pela comissão) que criticam e põe em xeque a avaliação.

Outro processo significativo na construção de atores sociais é a ativação contrapondo-se à passivação. Enquanto a primeira representa o ator com um caráter ativo e dinâmico, a segunda revela o ator como alguém que se submete aos acontecimentos ou como aquele que apenas recebe os acontecimentos sem uma reação efetiva. Segundo Van Leeuwen (1997), na esteira de Halliday (1985), o ator social pode ser sujeito ou beneficiado, ele é a “(...) Finalidade num processo material, é Fenômeno num processo mental, ou é Portador num processo atributivo específico.” (p. 189).

Quanto à coletivização ou a individualização de um ator social dentro de uma notícia de jornal, pode inferir vários aspectos e direcionamento político-social do enunciador e da empresa que ele representa, pois de acordo com Van Leeuwen (1997) “(...) os jornais dirigidos à classe média tendem a individualizar pessoas pertencentes às elites e a assimilar 'pessoas comuns', enquanto jornais dirigidos à classe trabalhadora, por vezes, individualizam 'pessoas comuns'.” (p. 194). 
A grande diferença existente entre a coletivização, vista no parágrafo anterior, e a agregação é que nesta última há uma quantificação dos grupos de atores sociais, tratando-os como dados estatísticos. De acordo com o pesquisador Van Leuween (1997) a “(...)agregação realiza-se através da presença de um quantificador definido ou indefinido que funciona como numerativo.” (p. 196).

As pesquisas realizadas por Van Leeuwen (1997), sobre a individualização ou não de um ator social em um texto sobre racismo, levaram às seguintes conclusões que poderemos estender para nossa pesquisa:

- O governo é quase sempre individualizado, sendo o líder apresentado como uma figura forte e o povo como um grupo consensual.

- Os especialistas são coletivizados, no entanto ao longo do artigo podem ser individualizados para citar os títulos, credenciais e afiliações institucionais destes estudiosos.

- Os imigrantes são mais frequentemente agregados, tratados como "dados estatísticos". (p. 196).

No processo de ator social, o autor apresenta também a indeterminação, que ocorre quando os atores são representados como indivíduos ou grupos não especificados, ou seja, anônimos; por outro lado, temos o fenômeno da determinação que consiste em revelar a identidade do ator ou grupo social, especificando-o. Quanto à nomeação desse indivíduo especificado, ela ocorre em três níveis:

- formal: o sobrenome é revelado;

- semi-formal: escreve-se o primeiro nome e o sobrenome do agente;

- informal: informa-se apenas o primeiro nome do indivíduo em questão;

Ainda segundo o linguista, uma forma de caracterização pela funcionalização do ator social ocorre quando ele é referido pela atividade, função social ou ocupação que exerce. A identificação é outro processo importante de construção do ator social e ocorre pelo uso de características mais ou menos estáveis e por isso se difere da funcionalização. Podemos discriminar três tipos de identificação. São elas:

- classificação: idade, sexo, origem, classe social, raça, religião etc.;

- identificação relacional: quase sempre com um caráter positivo é a relação de parentesco ou trabalho;

- identificação física: normalmente ocorre nas narrativas e se realiza por algo que ressalte, ou diferencie dos demais (gordo, alto, baixo, cabeludo etc.). 
Levando em conta a identificação relacional, Van Leeuwen (1997) diz ser este tipo de uso um pouco complicado na nossa sociedade, pois:

(...) o papel da identificação relacional é menos importante do que o da classificação e funcionalização, em especial no que diz respeito às relações pessoais de parentesco. A intromissão de tais relações na esfera das actividades públicas pode ser classificada de "nepotismo" ou "corrupção". (p. 204-205).

A avaliação é um processo mais subjetivo em que os atores sociais são referidos em termos que os qualifiquem em bons e/ou maus, admirados e/ou lamentados, amados e/ou admirados. A referência metonímica é de grande relevância para a análise dos atores sociais e se divide em quatro:

- espacialização: O ensino do Brasil vem se desenvolvendo a cada dia;

- autonomização do enunciado: O documento assinado pelo presidente Lula diz que haverá maiores investimentos na Educação;

- instrumentalização: Uma bala atingiu um aluno ontem ao sair da escola;

- somatização: Lula e Obama olharam para as pernas da brasileira (exemplos nosso).

$\mathrm{Na}$ autonomização do enunciado, temos a seguinte definição de Van Leeuwen (1997):

A autonomização do enunciado ocorre em relação aos "especialistas" e também em relação ao autor do artigo que se representa a ele próprio sempre, como se através da sua pessoa, "os fatos falassem por si”, sendo realizados através da substituição da referência anafórica pela referência à sua pessoa em partes anteriores do texto (p. 215).

Podemos chegar à conclusão de que a ativação ou não dos atores sociais denota a compreensão do enunciador a respeito do tema abordado. Assim, uma classificação ou uma funcionalização dos atores e o modo como isso é construído já poderia levar-nos a diferentes perspectivas, ou seja:

(...) o papel activo dos meios de comunicação social neste processo social, apesar da postura cuidada de neutralidade sugerida pelo modo como a maior parte da representação é atribuída a fontes que não a pessoa do escritor propriamente dito". (p. 220). 


\section{2 - O gênero discursivo notícia: definição}

A função do jornalismo, mais especificamente em relação à notícia, é a de dar ênfase aos conteúdos, pois "se propõe a processar informação em escala industrial e para o consumo imediato. As variáveis formais devem ser reduzidas, portanto, mais radicalmente do que na literatura" (Lage, 1985). A partir disso, podemos perceber qual o escopo do gênero notícia, sua circulação instantânea e o seu tempo de curta vida útil. Esses elementos fazem com que esse gênero seja ímpar e, ao mesmo tempo, de grande importância, não só dentro do jornal em si, pois ele mostra, exemplifica e reflete toda a sociedade e, além disso, indica ser um gênero de poder, na medida em que tem uma “escala industrial”, como disse Lage, mas também é frágil ao tempo, pois é consumido pela massa popular em menos de 24 horas.

O autor defende ainda que a “(...) comunicação jornalística é, por definição, referencial, isto é, fala de algo no mundo, exterior ao emissor, ao receptor e ao processo de comunicação em si. Isto impõe o uso obrigatório da $3^{\circ}$ pessoa (...).” (p. 39, grifo do autor). Tal citação pressupõe que no gênero notícia não há lugar, normalmente, para o uso da primeira pessoa, porque o foco está no fato ocorrido e não na experiência do repórter ao entrar em contato com a situação, ou os sentimentos do jornalista em relação aos fatos. $\mathrm{O}$ uso da primeira pessoa fica mais restrito no jornal aos editoriais ou artigos de opinião.

Já Grillo (2001) leva em conta o aspecto da neutralidade e o aspecto informativo do enunciador e por isso, segundo a autora, haveria a exclusão do uso da primeira pessoa “(...) o discurso constrói o extra-discursivo necessário à legitimação do seu lugar de produção." (p. 30).

Basicamente, segundo Melo (2003), o jornalismo impresso divide-se em:

- Jornalismo informativo: notícias;

- Jornalismo interpretativo: reportagens;

- Jornalismo opinativo: editorial, artigos de opinião etc.

Para Grillo (2001), “o discurso jornalístico caracteriza-se por sua completude e didaticidade, com vistas a assegurar a compreensão de um leitor não-conhecedor dos fatos relatados" (p. 56). Atualmente, as notícias se configuram muito mais didáticas, 
pois são tantos os fatos que ocorrem no mundo que isso leva o enunciador a pensar no leitor e na sua efetiva compreensão ao escrever a notícia. Isso não quer dizer que, ao pormenorizar os fatos, o enunciador consiga manter-se neutro, imparcial.

No caso deste trabalho, destacamos do jornalismo informativo o gênero discursivo notícia, cuja origem foi na Itália (Roma e Veneza) com os avvisi (15001700) que eram folhetos afixados nas portas de lugares de grande circulação de pessoas, para que pudessem ser vistos por um maior número de indivíduos e, assim, haver a propagação ou refutação dos principais eventos da época.

Os textos dos avvisi, em sua maioria, eram de cunho político e econômico. No início, tinham um caráter militante, pois eram amplamente distribuídos para que todos participassem das discussões e, ao mesmo tempo, se tornassem aliados ao movimento.

Segundo Grillo (2001), o modo como o jornal se dispõe nos dias de hoje marca suas características principais, mas o jornal impresso nem sempre foi postulado dessa maneira, pois:

(...) a configuração da página do jornal através do posicionamento e da articulação dos seus diversos expressivos (títulos, fotos, legendas, rubricas, etc.) é o aspecto mais característico do modo de significar da imprensa quotidiana atual. Entretanto, em suas origens, o jornal não possuía um plano de expressão tal como se apresenta atualmente sendo não muito distinto do livro. (p. 45).

\subsubsection{Bakhtin e seu Círculo}

Apontada sua origem histórica, passamos a tratar do gênero discursivo notícia e de sua organização. Para tanto, fundamentamo-nos nos estudos produzidos pelo Círculo Bakhtiniano, este círculo foi formado nos anos de 1920 e era constituído por Medvedev que em 1928 teve sua obra $O$ método formal nos Estudos Literários publicada. Mikhail Mikhailovich Bakhtin (1895 - 1975) que publicou em 1929 Problemas da Obra de Dostoiévski, e Valoschinov, no ano de 1929, lança seu livro Marxismo e Filosofia da Linguagem que contemplam os gêneros do discurso. Não entraremos aqui no mérito da autoria desses livros, que pode ser atribuída somente a Bakhtin ou ao Círculo como um todo, pois nem os estudiosos do assunto chegaram ainda a um consenso sobre o fato, 
apesar de indicadores mostrarem que seria muito difícil os três livros serem de autoria de apenas um deles.

Bakhtin foi um filósofo russo que nasceu em Orel, sul de Moscou, em 1895, e foi quem concebeu uma nova forma de classificação dos gêneros relacionando-os às esferas da linguagem. Esse estudioso afirmava que todo e qualquer enunciado é produzido pelo falante em seu contexto histórico, ideológico, social e cultural.

Para Bakhtin, a partir das trocas cotidianas (gêneros primários) é que se concretiza e cristaliza o gênero secundário, sobretudo o romance, com esferas ideológicas constituídas. As ideologias do cotidiano estão sujeitas à influência de todas as esferas; no entanto, na esfera secundária tem que haver uma estruturação diferente do gênero primário que não é nem elaborada nem estruturada, pois se trata da linguagem cotidiana.

Nesse sentido, as notícias aqui analisadas estariam inseridas no gênero secundário por pertencerem a uma esfera mais complexa, a jornalística. Nesta, estão alocados vários gêneros discursivos que organizam as atividades comunicativas. O gênero notícia é estruturado e elaborado para que o leitor do jornal consiga compreender e se ater às informações, configura-se pela lógica daquele que se insere no mundo, na sua cosmovisão ou na sua realidade empírica, retratada com o estilo da polifonia.

De acordo com Bakhtin (1997), há uma forte ligação entre a produção e a recepção da linguagem. Ou seja, é a partir da palavra que se constrói a linguagem, e constituem-se os vários tipos de gênero, como destaca:

O gênero sempre é e não é o mesmo, sempre é novo e velho ao mesmo tempo. O gênero renasce e se renova em cada nova etapa do desenvolvimento da literatura e em cada obra individual em dado gênero (...) é o representante criativo no processo de desenvolvimento literário." (p. 106)

Segundo Grillo (2001), o gênero caracteriza os diferentes enunciados pelo seu tema, estilo e construção composicional, produzindo um significado real a partir de um juízo de valor. Dessa maneira, o gênero seria uma interpretação do real a partir de um discurso, não havendo a possibilidade de um enunciado totalmente neutro. Mesmo naqueles enunciados em que se leve em conta somente o objeto com um estilo claro, 
"supostamente" neutro e objetivo em que há o apagamento do enunciatário, não há a possibilidade de haver neutralidade. Há a negação do outro, e isso já revela um fator que leva em consideração seu interlocutor. Quanto aos tipos de gêneros em Bakhtin (2006) temos:

- Conteúdo temático: sentido da enunciação;

- Discurso primário: troca verbal espontânea;

- Discurso secundário: textos em geral.

Quanto ao gênero na imprensa, de acordo com Grillo (2001) temos:

- Aspectos pragmáticos: condição de produção, esfera da comunicação verbal, situação de comunicação;

- Aspectos enunciativos: transparência da imprensa/ jornais de referência;

- Apagamento das condições de enunciação do discurso;

- Forte trabalho no interdiscurso;

- Legitimação social.

Já Maingueneau (2002) considera as práticas sociais como sendo tipo de discurso e o termo gênero do discurso estaria mais voltado a notícias e reportagens pertencentes a um mesmo discurso, diferente de Bakhtin que toma tipo de discurso como esfera da comunicação verbal.

Dessa forma, há uma retomada da fonte dentro dos gêneros discursivos porque cada evento é único dentro daquela produção textual, levando em consideração seu contexto e sua história. Nessa perspectiva, a parte que seria o texto representaria de certo modo o todo que corresponderia à sociedade, de modo geral, e o seu momento histórico.

\subsection{4 - Configuração do gênero notícia na atualidade}

Quanto à configuração e produção da notícia na época contemporânea, é preciso levar em consideração o espaço que uma notícia pode ter dentro da página do jornal impresso. Os gatekeepers ou mais conhecidos no Brasil como editores-chefe são os responsáveis pela publicação ou não das notícias. Assim, às vezes, as notícias são 
cortadas para dar lugar a um anúncio de uma grande empresa e, com isso, o jornalista não tem o tempo ou espaço para tratar de uma notícia como um especialista em uma revista científica mensal ou bimestral teria. Esse prazo maior possibilitaria uma visão mais abrangente dos assuntos tratados, já que se faz necessário um relativo grau de distanciamento local e temporal em relação aos fatos para haver maior discernimento, mas para um jornalista nem sempre há essa possibilidade devido à dinâmica do jornal.

Além desse aspecto, é necessário destacar outros elementos que fazem parte da construção das notícias, tais como o lead, a hard news, os tipos de verbos empregados, entre outros. O lead é a proposição principal da notícia. Trata-se dos primeiros parágrafos do texto que apresentam seis questões a serem respondidas: quem, como, onde, quando, o que e por quê. As informações consideradas mais importantes aparecem, contrariando a ordem natural, logo no início da manchete e no subtítulo; depois, apresenta-se o parágrafo de lead e, então, o corpo do texto (body) é desdobrado.

O lead chamado clássico é formado por três a cinco linhas, o que corresponde mais ou menos a 70 toques; já o sublead é o segundo parágrafo da notícia e tem o mesmo tamanho do lead. As sub-retrancias ou retranca são os demais títulos relacionados ao primeiro título: por exemplo, a seção "Outro Lado" aparece ao longo das notícias da FSP para contemplar outros pontos de vista ainda não mostrados em um primeiro momento, a respeito de determinado fato noticiado, em que é comum a utilização de verbos dicendi (disse, afirmou, declarou, perguntou etc.).

A hard news, por sua vez, é uma expressão inglesa que designa a linha editorial especializada em notícias e coberturas mais complexas e densas, como as de fatos econômicos e políticos, bem como sua contextualização, análise e projeções.

Quanto à estrutura gramatical de um lead clássico, inicia-se pelo sintagma nominal ou pela circunstância mais importante e quase nunca pelo verbo. Caso o objeto direto seja o mais importante da notícia, ela é construída na voz passiva; se o objeto indireto for aquilo a que se quer dar destaque, recorre-se à semântica. O lead para Lage (1978, p. 20) é a "proposição principal da notícia"

Abaixo segue um exemplo de lead de uma notícia ${ }^{9}$ pertencente ao corpus coletado no jornal FSP, do dia 4 de abril de 2007:

\footnotetext{
${ }^{9}$ Trata-se da notícia 26, localizada no anexo 3 do corpus desta pesquisa.
} 


\section{MEC exigirá que professor seja avaliado}

As medidas são inspiradas nas práticas pedagógicas de 200 municípios com média superior a 5 no novo indicador do MEC, o Ideb, que leva em conta o desempenho local na Prova Brasil (que avalia a qualidade) e as taxas de aprovação. No que diz respeito aos professores, além de instituir avaliação do desempenho, o decreto vai exigir a implementação de um plano de carreira, cargos e salários, que deve "privilegiar o mérito, a formação e a avaliação do desempenho".

Quanto aos verbos utilizados nas notícias, comumente, empregam-se os perfectivos para os eventos já concluídos ou que acabaram de ser concluídos, e os verbos imperfectivos para os eventos que ainda não tenham terminado. A esse respeito, Lage (1987) apresenta o seguinte esquema didático para qual encontramos exemplos do corpus:

a) verbos no pretérito perfeito, se a notícia é sobre um fato acontecido:

A Anamec constatou que muito dessa migração deve-se à busca, pelos pais dos estudantes, de escolas que, acreditam eles, preparará melhor seus filhos para o vestibular.

b) verbos no futuro ou futuro próximo (uso do presente no lugar do futuro), se a notícia anuncia fato previsto:

O secretário executivo da associação, Eurico Borba, calcula que, por ano, três escolas católicas encerrem suas atividades, os estudantes migrando para outros estabelecimentos.

c) verbos no presente, muito raramente são empregados, mesmo na narrativa concomitante (de um repórter no rádio ou televisão):

"Estudar mais é necessário e faz diferença na hora de enfrentar o vestibular", explica a educadora Sônia Teresinha de Sousa Penin, próreitora de Graduação da USP. (p. 28, grifo nosso)

Há um uso estratégico relacionado ao aspecto argumentativo dos verbos imperfectivos quando não se quer a construção de uma notícia negativa ou com valores ideológicos. Assim, por exemplo, em vez de dizer que "o nosso vice-presidente José Alencar não morreu", declara-se: "José Alencar continua resistindo ao câncer".

Visto que, atualmente, a notícia é estruturada como o relato de vários fatos a partir do que se considera mais importante ou significativo, outro ponto a ser destacado é a diferenciação entre uma simples narração e a notícia propriamente dita, pois na notícia há uma ordenação de fatos ou eventos, em que são priorizados os de maior relevância, prezando o melhor e mais rápido entendimento do leitor e em que se deve levar em conta a seleção lexical e o efeito de sentido pretendido. 
A partir dos quesitos elencados para se definir uma notícia, podemos levantar aqui outra questão: qual é o limite da narração de um fato em poucas linhas - muitas vezes condicionado pelo espaço que o editor determina - e o fato verídico com todas as suas implicações, questões e pontos de vista?

Para Lage (1987), a notícia está intimamente ligada ao mundo da aparência e não da realidade fidedigna, pois:

(...) o noticiário não permite o conhecimento essencial das coisas, objeto de estudo científico, da prática teórica, a não ser por eventuais implicações a fatos concretos. Por detrás das notícias corre uma trama infinita de relações dialéticas e percursos subjetivos que elas, por definição, não abarcam. (p. 23-24).

O que podemos perceber pela citação é que o jornalista não tem tempo hábil para inteirar-se plenamente do assunto, já que o jornal precisa estar pronto de madrugada para a sua impressão e o leitor não quer notícia ultrapassada. Dessa maneira, o jornalista "luta" contra o tempo e escreve, muitas vezes, concomitantemente aos fatos.

Se a notícia se encontra no mundo das aparências e não da coisa em si, como foi dito por Lage (1987) no último excerto, temos o conceito de verossimilhança proposto por Aristóteles que afirma não ser tão importante "ser verdadeiro", mas sim "parecer verdadeiro". Dessa maneira, aí se encontra a essência do verossímil, aquilo que é passível de ter acontecido.

Batista (2009) analisa como a circulação de discursos opera as mudanças nas tomadas de posição dos enunciadores, ou seja, como os discursos são retomados e repassados, como o novo enunciador relata a enunciação de outrem a partir de seu lugar social, como o relator apresenta e avalia o ato de enunciação alheio o qual usa para construir o seu. O autor considera a mídia como "Quarto Poder" e, disfarçada de libertária e democrática a imprensa com uma suposta ética, faz-se como sendo imparcial, analítica. No entanto, os enunciados demonstram muito mais que opiniões sensatas e sutis sobre fatos e apresentam interesses de uma elite dominadora.

Muitas vezes o enunciador mostra, veladamente, sua tomada de posição e modifica, aprimora ou tenta manter o sentido do que é relatado, dissimulando-se ao seu interlocutor como se fosse neutro, ou seja, mero informante dos fatos e não defensor de uma classe detentora de poder, segundo Van Dijk (2008). 
Dessa forma, entendemos ser relevante desenvolver alguns aspectos da relação entre argumentação e polifonia que será abordada mais detalhadamente no próximo item desta dissertação.

\section{3 - A argumentação: estratégias discursivas e a construção da notícia}

Neste trabalho, é importante que se discuta a argumentação, pois a polifonia é uma das estratégias discursivas que os jornalistas, muitas vezes, podem utilizar como uma forma de se redimir de uma eventual culpabilidade frente a um tema polêmico e também para dar maior credibilidade ao texto, utilizando o argumento de autoridade e outros tipos de estratégias polifônicas. Esses são, entre muitos outros, os potenciais recursos de usos dos discursos direto e indireto na construção de uma notícia impressa.

Koch (1996) define a argumentatividade como sendo:

(...) uma atividade estruturante de todo e qualquer discurso, já que a progressão deste se dá, justamente, através das articulações argumentativas. A orientação argumentativa dos enunciados que compõem um texto deve ser considerada, portanto, como um fator básico não só de coesão, mas principalmente de coerência textual. (p. 21).

Segundo Citelli (1991), a retórica clássica surge no estado grego para que as camadas sociais de maior prestígio pudessem dominar regras e normas da boa argumentação. "O exercício do poder via palavra, era ao mesmo tempo uma ciência e uma arte, louvado como instância de extrema sabedoria" (p. 9), sendo assim, foi neste período que aconteceram as primeiras reflexões e sistematização da língua, tendo como estudiosos da linguagem pensadores como Sócrates, Platão e Aristóteles. Para este último, a retórica está ligada à Ciência, na medida em que existe um processo investigativo no processo de constituição da persuasão. A persuasão é definida por Citelli como “(...) sinônimo de submeter, daí sua vertente autoritária. Quem persuade leva o outro à aceitação de uma idéia dada” (p. 13).

Para Aristóteles (2007) no seu livro intitulado Retórica, a retórica seria:

(...) a contrapartida da Dialética. Ambas referem-se a assuntos mais ou menos da compreensão humana e não pertencem a uma ciência 
definida. Assim, todos os homens fazem uso delas em maior ou menor medida, pois tentam, de certo modo, questionar e sustentar argumentos, defendendo-se a si próprios e acusando outros. Pessoas comuns fazem-no aleatoriamente ou por meio de práticas adquiridas. (p.19).

Aristóteles (2007) atribui à retórica o conceito de verossimilhança e não o conceito de ética ou verdade, porque um discurso para ter efeito não precisa necessariamente ser verdadeiro na práxis, mas um discurso - para ter sentido e chegar à persuasão - necessita primeiramente ser passível de ser verdadeiro. Dessa forma a retórica “(...) não entra no mérito daquilo que está sendo dito, mas, sim, no como aquilo que está sendo dito o é de modo eficiente. Eficácia implica, nesse caso, domínio de processo, de formas, instâncias, modos de argumentar.” (p. 11).

A persuasão, segundo Aristóteles, depende da intenção do enunciador que motiva a sua escolha "consciente" das estratégias utilizadas para que se atinja o público. O enunciador seria considerado, dessa forma, mais ou menos hábil de acordo com o escopo que tenha atingido o público-alvo; no entanto, tal enunciador não poderia se utilizar de sua aparência para ganhar seus enunciatários.

O que o enunciador deveria suscitar no público seriam as paixões, pois é a partir delas que o público vai ser afetado e levado a uma ação de fato. Segundo Aristóteles (2007) elas são "as causas que introduzem mudanças em nossos juízos, e que são seguidas de pena e de prazer; tais são a cólera, a compaixão, o temor e todas as outras emoções semelhantes, bem como seus contrários" (p. 97). O filósofo grego denuncia o potencial de persuasão que todos os discursos, sobre assuntos diversos, têm e que os caracterizam como gêneros independentes.

Já na Nova Retórica, que tem como grandes estudiosos os pesquisadores Perelman \& Olbrechts-Tyteca (2005), há a retomada do trabalho de Aristóteles sob a perspectiva do enunciatário e da construção argumentativa que este efetiva. Perelman \& Olbrechts-Tyteca defendem que toda argumentação é retórica e não lógica, devido ao fato de a última estar diretamente ligada a premissas inquestionáveis. Desse modo, não haveria necessidade de prová-las por meio da argumentação. O autor parte do pressuposto segundo o qual o sucesso da argumentação está relacionado ao fato de como a verdade é articulada e não, necessariamente, da verdade absoluta dos fatos. 
Sendo que a expressão desta "verdade" estaria ligada às mídias que têm o poder da palavra.

A principal diferença entre premissa e persuasão é que enquanto a primeira corresponde a princípios que seriam aceitos por um enunciatário universal, a segunda, a persuasão teria seu público particularizado. Outra questão que se deve levar em conta é a ordem dos argumentos. Ela pode ser do mais forte para o mais fraco e vice-versa, dependendo do impacto que se quer obter; no entanto, Perelman \& Olbrechts-Tyteca (2005) defendem que a quantidade não tem grande valia se não for embasada no contexto. Dessa maneira, as provas têm que estar adequadas a seu público, ao "auditório".

Ao tratar sobre a organização textual, Citelli (1991) declara ser esta não apenas constituinte de regras formais, mas sim que a preferência de um recurso linguístico a outro denuncia um cunho ideológico. Com relação à neutralidade da língua, podemos perceber a opinião do autor como no trecho que se segue:

Se as palavras, por exemplo, nascem neutras, mais ou menos como estão em estado de dicionário, ao se contextualizarem, passam a expandir valores, conceitos, pré-conceitos. Nós iremos viver e aprender em contato com outros homens, mediados pelas palavras, que irão nos informar e formar. As palavras serão por nós absorvidas, transformadas e reproduzidas, criando um círculo de formação e reformulação de nossas consciências. (p. 28).

Para Citelli (1991), o discurso persuasivo está estritamente ligado ao discurso institucional, uma vez que o primeiro faz-se do uso de "uma verdade" e a torna uma "verdade absoluta", podemos perceber esse fenômeno em instituições que falam "(...) através dos signos fechados, monossêmicos, dos discursos de convencimento.” (p. 32).

Ao compreender que o poder é uma forma de exercer influência sobre o outro e ao entender a polifonia como estratégia argumentativa, retomamos os dois tipos de argumentação: o demonstrativo, ligado ao campo universal da matemática, e o persuasivo, que está no âmbito do verossímil. Fundamentamo-nos no segundo tipo para análise da polifonia, principalmente nos estudos de Perelman \& Olbrechts-Tyteca (2005), os quais fazem a distinção entre convencer e persuadir: sendo o primeiro ligado ao raciocínio sólido que leva o enunciatário a pensar como o enunciador, apelando, 
dessa forma à razão, enquanto o segundo está mais ligado à inteligência e ao sentimento, ou seja, à emoção.

Segundo Perelman \& Olbrechts-Tyteca (2005), para que uma argumentação seja realmente eficaz é necessário que haja um consenso prévio entre orador (enunciador) e os interlocutores (enunciatários), nesse acordo o enunciador presume que haverá aceitação por parte dos enunciatários. Dessa maneira, o jornalista/jornal sempre tem que levar em conta, ao redigir/publicar uma notícia, se ela será, supostamente, "consumida" pelos leitores, mesmo que seja para chocar.

Em toda construção textual é preciso sempre levar em consideração o "outro", pois a partir desse elemento é que o discurso do enunciador vai ser produzido, visando ao convencimento, à adesão e à ação do seu enunciatário. Na relação entremeada do eu e do outro, surgem os conflitos que são evidenciados pela negação. A partir da negação, tenta-se falsear a fala do outro; no entanto, é impossível esconder no texto todas as vozes latentes que nele coexistem.

Para que haja o convencimento e/ou a persuasão do "outro", o enunciador pode se utilizar das tipologias de argumentação que, segundo Platin (2005), classificam-se em: divisão de enunciados, argumentações sobre a pessoa, argumentações de autoridade, negação.

Outro fator importante na seleção de argumentos é levar em consideração a força de tais argumentos, porque, segundo Perelman \& Olbrechts-Tyteca (2005), essa força se define com a amplitude de adesão ou não do auditório. Quanto maior for a amplitude, mais forte será o argumento.

No caso do jornal, o enunciador precisa construir seu texto de maneira que os leitores se convençam daquilo que ele escreveu. A opinião de quem escreve está sempre presente no texto, mesmo que de modo velado ou implícito. O uso de argumento de autoridade, a seleção lexical, a inserção de uma declaração e não de outra denotam a visão de mundo do enunciador. Essas estratégias estão atreladas à produção da notícia, considerando que, estruturalmente, tal gênero se define como o relato de uma série de fatos selecionados pela ótica do jornalista.

É a partir das relações estabelecidas entre os participantes da enunciação que se forma o discurso, a fim de que haja o enquadramento do que pode ser aceito 
socialmente ou não. Assim, o vínculo intrínseco do discurso que se produz com a realidade apresentará uma visão de mundo coerente e o mais adequada possível, visando a ocultar qualquer formação ideológica díspar ao discurso formado.

Bakhtin (2006) vê o enunciado como explicação da estrutura semântica. O estudioso russo concebe a língua como prática social em que o outro assume um papel importante na formação do significado. É a partir do outro que o enunciador constrói e dirige o seu texto. Para ele, a palavra é ideológica, pois a linguagem é lugar de conflito, de confronto e não pode ser desvinculada da sociedade, pois seus processos são histórico-sociais.

Brandão (2002) faz um levantamento de vários filósofos que se debruçaram sobre o tema ideologia, tais como: Marx e Ricoeur. Dentre as diferentes propostas elaboradas por esses estudiosos, percebe-se que, sob a perspectiva de Marx, a ideologia é apenas uma visão de mundo que apaga outros discursos, porque não quer se mostrar contraditória. Essa visão sempre está atrelada à classe social dominante, para que o grupo pense que esta é a única forma de viver. No entanto, Ricoeur propõe um conceito de ideologia diferenciado, que leva em conta a história e a motivação de um grupo. Para este autor, a linguagem está atrelada à ideologia e esta se manifesta a partir do uso daquela.

Outro conceito importante trabalhado por Brandão (2002) e que será de vital importância para o entendimento dos demais conceitos são as formações discursivas, pois são elas "que determinam o que pode e o que não pode ser dito". Dentro de um mesmo discurso podem existir várias formações discursivas que operam de duas formas: pela paráfrase, que consiste em "enunciados retomados e reformulados", e pelo pré-construído que seria “o que cada um sabe e o que cada um pode ver” (p. 38-39).

Nesse sentido, procuramos estabelecer uma relação entre as vozes que aparecem no texto e a questão do poder. Van Dijk (1992) defende que o poder se estabelece quando uma pessoa influencia outra de forma a reconduzir os pensamentos e atos da segunda, restringindo, de certo modo, a sua liberdade de ação.

Para que haja uma relação de poder, primeiramente, é preciso se ter acesso ao poder e, segundo Aquino (1997) isto ocorre por meio do "modo como as pessoas tomam iniciativa nos eventos comunicativos, as modalidades de sua participação, os 
meios que controlam as várias outras propriedades do discurso" (p. 83-84). Desse modo, o poder e o domínio do enunciador ocorrem em sucessivas e graduais situações, e dependem do escopo, ou seja, do número de leitores que o enunciador consegue atingir por meio do seu discurso.

\section{4 - A polifonia: vozes conjuntas ou divergentes na construção da notícia}

Em vista do que foi exposto anteriormente, passaremos a discutir o conceito de polifonia. Trata-se, de modo geral, de um fenômeno que traz para um texto a voz do outro. Ao tratar da questão da subjetividade da linguagem, Benveniste (1991) apresenta a concepção de um "eu" e de um "tu” que se constituem, se entrelaçam e se confundem dentro de uma cena enunciativa. Por sua vez, Bakhtin (2006) afirma que o "eu" constitui-se e modaliza-se a partir do "outro".

Para o último autor, não se pode conceber o discurso como sendo monológico, todo discurso é antes de tudo polifônico, pois o discurso se tece em um jogo de várias vozes que se cruzam e ao mesmo tempo se complementam, concorrem entre si e, por fim, se contradizem. Na perspectiva bakhtiniana, o discurso é dialógico e polifônico na medida em que, mesmo sendo um "eu" que tece o discurso, esse discurso está atrelado a enunciados anteriores, estabelecendo relação de intertextualidade com esses enunciadores, e ao público a que se destina, portanto o "tu" (o outro) está presente na construção textual.

Contudo, entendemos que a polifonia vai além da simples introdução de uma voz ou de um efeito de autoridade no texto, pois consideramos que se trata de um processo em que a escolha de um determinado trecho do discurso e não de outro implica uma estratégia argumentativa que visa alcançar determinado efeito de sentido.

Assim, é preciso considerar de quem é a voz trazida para o texto e que efeitos de sentido podem ser construídos a partir do trecho enunciado e selecionado. Por exemplo, se, em uma notícia, o jornalista usa a declaração do presidente dizendo que o ensino no Brasil vai melhorar, há um foco argumentativo diferente daquele que a notícia teria se a mesma declaração fosse oriunda da mãe de um aluno da rede estadual de ensino, declarando que sente confiança no ensino público. Dessa maneira, podemos perceber 
que a polifonia pode revelar diferentes intencionalidades, dependendo do objetivo do enunciador. Como afirma Grillo (2004):

\begin{abstract}
A colocação em cena de discurso envolvido nos acontecimentos narrados, por meio do uso do discurso relatado, é um recurso produtor de um "efeito de verdade" dos acontecimentos descritos pela imprensa (...) o discurso relatado funciona como testemunha autentificadora do relato jornalístico (...) pode funcionar como um duplicação do real. (p. 88-89).
\end{abstract}

Entre os efeitos de sentido criados quando se faz uso da polifonia, podemos citar o de proporcionar veracidade ao que é enunciado por meio, por exemplo, do argumento de autoridade. Isso ocorre quando o enunciador quer legitimar seu enunciado a partir de assertivas que corroborem sua opinião. Por isso, ao transcrever a fala de alguém em uma notícia, o jornalista busca com essa outra voz criar o efeito de verdade, de autoridade, pois denota a opinião de uma pessoa envolvida dentro da questão tratada, conforme declara Grillo (2004):

A relação texto/paratexto produz efeito de autenticidade do relato jornalístico, pois, por um lado, o jornal faz ouvir a sua voz por meio de fontes e, por outro, o leitor identifica a exterioridade das suas afirmações. $\mathrm{O}$ 'discurso direto preparado' do texto, durante o processo de produção jornalística, é adaptado à norma-padrão escrita do português e pode sofrer alterações estruturais, sem, com isso, perder seu efeito de fidelidade. (p. 101-102).

Assim, podemos dizer que escrita e fala se confundem e confabulam para a sedimentação de um texto. É importante também ressaltar que um jornalista, ao citar direta ou indiretamente a fala de alguém em sua notícia, pode entremear e revelar a sua própria opinião e visão de mundo por meio dessa fala, nem sempre correspondente à realidade. Dependendo da estrutura argumentativa em que é inserida, a polifonia pode tomar outros contornos, outros significados.

No mais a polifonia pode criar no texto um tom irônico, ou então pode-se usá-la como forma de se contra-argumentar a opinião/declaração do outro. Por exemplo, na guerra dos E.U.A. versus Iraque, segundo estudos de Resende \& Ramalho (2006), nas reportagens das revistas Veja e Caros Amigos, houve um comprometimento e o uso da 
polifonia: enquanto foram apresentadas, por um lado, várias vozes de pessoas representativas, de autoridades da sociedade ou do governo norte-americano, por outro, as declarações que vinham do Iraque eram sempre de radicais extremistas, cujos atos radicais são representativos de pessoa que tem a sua individualidade englobada para caracterizar o povo iraquiano de modo geral. Isso nos revela o quanto a notícia ou a reportagem pode manipular a voz alheia.

Tal manipulação pode ser entremeada por um tom negativo do enunciador que se apropria da voz do outro com o intuito de contestar aquilo que foi dito por seu enunciatário. Ao discutir a respeito de como as palavras do outro podem ser revestidas de avaliação por parte daquele que fala, Bakhtin (1997) assim define a gradação do tom negativo:

É característica a gradação do tom negativo (para contrariar o outro) sob a influência da reação antecipável do outro. Semelhantes quebras levam sempre a um amontoamento de palavras exprobratórias que se intensificam, cada vez mais, ou em todo caso, de palavras indesejáveis para o outro. (p.231).

Diante dessas perspectivas, a polifonia é entendida como a utilização de outras vozes dentro do discurso para que haja reconhecimento e legitimidade para o próprio discurso (isto é o discurso do enunciador), na tentativa de não deixar margem para que haja refutações. Muitas vezes, são utilizadas vozes de autoridades ou figuras de destaque social para a corroboração de uma tese. Nesse sentido, é relevante atentar para a ação dos verbos introdutores de opinião (Marcuschi, 2002), para verificar como foram utilizadas as diferentes vozes dentro de uma mesma notícia, vozes estas denominadas aqui de polifonia.

Para Koch (2001), a polifonia pode ser considerada como um "fenômeno pelo qual, num mesmo texto, se fazem ouvir 'vozes' que falam de perspectivas ou pontos de vista diferentes com as quais o locutor se identifica ou não". (p. 58).

\subsubsection{Discurso citado}

O discurso citado vai além do discurso direto, indireto e indireto livre, ou pelas palavras colocadas entre aspas. Atualmente, se faz necessário uma análise mais profunda e contextual em que o jogo de vozes seja interpretado como submisso, autoritário, irônico etc. 
Para Bakhtin (Volochinov, 2006) "o discurso citado é o discurso no discurso, a enunciação na enunciação, mas é, ao mesmo tempo, o discurso sobre o discurso, uma enunciação sobre a enunciação". (p.150).

Os discursos citados se dividem basicamente em discurso direto e discurso indireto, no entanto, veremos a seguir que essa classificação, além de ter se expandido segundo alguns autores, também possui pequenas diferenças conceituais de um autor para outro. Grillo (2001), define os tipos de discurso como veremos a seguir:

1) Discurso narrado (...) reduz-se a uma descrição semelhante ao dos acontecimentos e integrando-as ao discurso citante. Do ponto de vista formal, o discurso-citado subsiste com a presença de um verbo de elocução e é mencionado sob a forma de um infinitivo ou de um sintagma nominal, o que o diferencia do discurso indireto;

2) Discurso indireto (...) Ele é admitido antecipadamente como uma condensação de falas que são integradas pelo narrador a seu próprio discurso e são interpretadas em seu estilo próprio;

3) Discurso direto (...) o narrador simula ceder literalmente a fala a seu personagem, reproduzindo-a em seu estilo e conteúdo "original". (...) Para Maingueneau (2002), a escolha do discurso direto está ligada ao gênero do discurso e desempenha três funções: mostrar autenticidade através da citação das próprias palavras, colocar-se à distância e mostrar-se objetivo, sério;

4) Modalização em segundo discurso (...) expressões como 'segundo' e 'conforme' (...) modalizam pelo envio a um outro discurso;

5) Ilhas textuais são elementos que resistem à atividade de tradução, sendo inseridos entre aspas no discurso narrado, no discurso indireto e na modalização em segundo discurso. (...) Com isso, as ilhas podem conferir um efeito de fidelidade (aos textos) que sozinhos, se caracterizam pelo distanciamento do discurso citado. (p. 110/111).

Para Carmagnani (1996), discurso relatado seria o que foi posto por Grillo (2001) como sendo discurso citado. O discurso relatado estaria divido em discurso direto e discurso indireto. A autora defende que o uso do discurso relatado nos jornais tem a função de: 1) não assumir a responsabilidade daquilo que foi dito; 2) mostrar objetividade e aparente transparência; 3) mostrar maior proximidade com o leitor, principalmente no discurso direto.

\subsubsection{Uso das aspas}

As aspas têm o objetivo, no discurso direto, de marcar a fala do outro no meio do discurso. Elas podem ser utilizadas pelo enunciador como uma forma de se proteger antecipadamente de futuras críticas, mas, por outro lado, o enunciador pode omitir as aspas como meio de chocar seu enunciatário e causar polêmica. 


\subsubsection{Argumento de autoridade}

O conceito de atores sociais está totalmente imbricado no processo linguístico de argumento de autoridade, pois no momento em que há a legitimação e a super valorização da individualização, ocorre nos textos, seja jornalístico, científico ou não, o argumento de autoridade. Esse tipo de argumento se utiliza do prestígio social, político, financeiro etc. de uma pessoa ou grupo de pessoas para prover aceitação de uma determinada tese que defende. Conforme Grillo (2004) expõe:

Há vozes mais ou menos valorizadas, em razão, sobretudo, da identidade ou do distanciamento da linha editorial do jornal. A percepção desses procedimentos é fundamental para que o leitor identifique a linha argumentativa, julgue as posições em conflito e assuma, com independência, uma posição pessoal. (p. 102).

Tal argumento é de grande funcionalidade quando há julgamentos de valor e/ou assuntos polêmicos. Dessa maneira, quando há controvérsia o que é questionado não é o argumento em si, mas a autoridade usada no texto. Segundo Carmagnani (1996), "o confronto de autoridade gera necessidade de estabelecimentos de critérios que atualmente se concentram na 'competência' (o mais utilizado), tradição, antiguidade ou universalidade (p. 34).

Dessa maneira, porque não falar da voz de autoridade entremeada pela instituição oficial ou de prestígio social. A questão que se levanta aqui é sobre quem tem o direito de falar e quando, sobre qual é essa voz que tem espaço dentre tantas outras vozes que, na maior parte do tempo, são ignoradas, excluídas e até menosprezadas. A tentativa de resposta se encontra em Citelli (1991):

\footnotetext{
A ponte por onde transita a mistificação da competência é a palavra, é o discurso burocrático-institucional com seu aparente ar de neutralidade e sua validação assegurada pela cientificidade. Afinal, quem afirma é o doutor, o padre, o professor, o economista, o cientista etc.! Isso ajuda a perpetuar as relações de dominação entre os que falam $a$ e pela instituição e os que são por ela falados. Os segundos, sem a devida competência, ficam entregues a uma espécie de marginalidade discursiva: um reino do silêncio, um mundo de vozes que não são ouvidas. (p. 35).
}

Esses doutores, padres e cientistas que afirmam, são, na verdade, constituídos de autoridade devido às instituições que representam, como poderemos notar ainda em Citelli (1991): 
Quem fala é o Ministério da Fazenda, através do seu corpo técnico; a Sociedade Médica através se seus doutos membros; a grande corporação multinacional através de seus executivos etc. Autorizado pelas instituições, o discurso se impõe aos homens determinando-lhes uma série de condutas pessoais. (p. 36).

Assim, se o discurso é composto por figuras populares, sem poder de legitimação, esse texto não tem validade, mas se for um discurso dotado de "caráter", de declarações de autoridades sociais instituídas de valor, dificilmente ele será contestado pela sociedade.

\subsubsection{Verbos introdutores de opinião}

Esta teoria de Marcuschi (2007) é de suma importância para o desenvolvimento deste trabalho, pois é a partir das classificações que o professor Marcuschi faz é que abordaremos, classificaremos e analisaremos os verbos dicendi. Veremos essa classificação mais adiante. Por agora, verificaremos que o autor se diz contrário à crença de que a notícia é totalmente objetiva e se utiliza dos verbos introdutórios de opinião para comprovar a subjetividade do texto jornalístico. Isso ocorre na interpretação, seleção ou avaliação dos discursos inseridos na notícia, nesse sentido o autor afirma que:

(...) apresentar ou citar o pensamento de alguém implica, além de uma oferta de informações, também uma certa tomada de posição diante do exposto. Assim, a avaliação linguística terá um caráter não meramente estilístico, mas sobretudo interpretativo e avaliativo. $\mathrm{O}$ mais notável é que isso se processa através do instrumento linguístico usado e não mediante uma interpretação explicita paralela. Não me refiro, portanto, aos comentários; refiro-me tão somente às palavras que introduzem opiniões alheias com pretensão de felicidade ao pensamento do autor. (p. 147).

Segundo o autor, a opinião não vem anexada por um sintagma específico que a identifique como tal, mas surge como se fizesse parte do texto em si, fundindo-se nele. Marcuschi (2007) dividiu as formas de "interpretação" da manipulação dos enunciados nos textos jornalísticos em três aspectos diferentes, apresentados a seguir:

a) Interpretação explícita, em que há um comentário feito pelo redator da notícia;

b) Interpretação implícita, que é feita pela seleção dos verbos que introduzem as opiniões ou por expressões equivalentes, sem um comentário adicional;

c) Interpretação pela seleção, do que é informado. $\mathrm{O}$ fato de se prestar uma e não outra parte das opiniões de alguém já é uma forma de 
interpretar o discurso através da omissão. A simples seleção é, pois, um tipo especial de interpretação pelo interesse. (p.150/151).

Portanto, o autor considera qualquer informação como forma de interpretação, ou seja, sempre haverá um discurso interpretado. Dessa maneira, a opinião pode ser montada a partir de contrapostos e é onde os verbos introdutores de opinião ganham uma função importante dentro do texto. Às vezes, a partir de um desses verbos, podemos dizer que alguém disse algo que não disse exatamente. Esta manipulação sutil é chamada de interpretação implícita.

Marcuschi (2007) divide os tipos de discurso em Discurso de Poder e Discurso de Populares. O primeiro é divido em três que são:

1) Discurso Oficial: discurso do governo (Executivo, Legislativo e Judiciário) e ainda o militar;

2) Discurso para-oficial: produzido por algumas camadas do Clero que são simpatizantes do governo;

3) Discurso da oposição: sindicatos patronais e outras Instituições que são opostas ao governo;

O pesquisador afirma que, enquanto os discursos oficiais e para-oficiais são considerados verdadeiros, o discurso da oposição é visto com certa reserva e a responsabilidade recai em quem produziu. Os verbos mais fortes e dominadores são mais comumente usados pelo discurso relatado do Governo, como por exemplo, reiterar, frisar, sentir, classificar, ressaltar, afirmar, destacar etc. Dessa forma, o enunciador corrobora implicitamente com os ideais oficiais.

Já o Discurso de Populares, segundo Marcushi (2007) é aquele produzido por pessoas anônimas e que quase nunca são lembradas nas entrevistas ou nos noticiários.

\footnotetext{
A questão central aqui colocada é a de saber até que ponto é possível informar a opinião de alguém sem ao mesmo tempo interpretá-la de alguma forma ou em alguma direção. Tudo se resume no seguinte: qual a diferença em se relatar que alguém "disse" algo ou que alguém "declarou", “enfatizou", “confirmou", "reiterou”, "revelou", "advertiu", "contou", "condenou", "elogiou", "confessou", "achou" isso ou aquilo com o seu discurso? A hipótese que tento defender é a de que a ação desses verbos hierarquiza, reforça, discrimina, classifica etc. os autores das respectivas opiniões relatadas. (p. 158).
}

Tais verbos introdutores de opinião foram divididos por Marcuschi (2007) como está apresentado no seguinte quadro: 


\begin{tabular}{|c|c|}
\hline Função & Exemplos \\
\hline $\begin{array}{l}\text { Indicação de posições oficiais e } \\
\text { afirmações positivas }\end{array}$ & $\begin{array}{lll}\text { Declarar, } & \text { afirmar, } & \text { comunicar, } \\
\text { informar, } & \text { anunciar, } & \text { confirmar, } \\
\text { assegurar, etc. } & \end{array}$ \\
\hline Indicação da força de argumento & $\begin{array}{l}\text { Frisar, ressaltar, sublinhar, acentuar, } \\
\text { enfatizar, destacar, garantir, etc. }\end{array}$ \\
\hline $\begin{array}{l}\text { Indicação da provisoriedade do } \\
\text { argumento }\end{array}$ & $\begin{array}{l}\text { Achar, julgar, acreditar, pensar, } \\
\text { imaginar, etc. }\end{array}$ \\
\hline $\begin{array}{l}\text { Organização de um momento } \\
\text { argumentativo no conjunto do discurso }\end{array}$ & $\begin{array}{l}\text { Iniciar, prosseguir, introduzir, } \\
\text { concluir, inferir, acrescentar, } \\
\text { continuar, finalizar, explicar, etc. }\end{array}$ \\
\hline $\begin{array}{l}\text { Indicação de retomadas opositivas, } \\
\text { organização dos aspectos conflituosos }\end{array}$ & $\begin{array}{l}\text { Comentar, reiterar, reafirmar, negar, } \\
\text { discordar, temer, admitir, apartear, } \\
\text { revidar, retrucar, responder, indagar, } \\
\text { defender, reconhecer, reconsiderar, } \\
\text { reagir, etc. }\end{array}$ \\
\hline $\begin{array}{l}\text { Indicação de emocionalidade } \\
\text { circunstancial }\end{array}$ & $\begin{array}{l}\text { Desabafar, gritar, vociferar, esbravejar, } \\
\text { apelar, ironizar, etc. }\end{array}$ \\
\hline $\begin{array}{l}\text { Interpretação do caráter ilocutivo do } \\
\text { discurso referido }\end{array}$ & $\begin{array}{l}\text { Aconselhar, criticar, advertir, } \\
\text { enaltecer, elogiar, prometer, condenar, } \\
\text { censurar, desaprovar, incentivar, } \\
\text { sugerir, exortar, admoestar, etc. }\end{array}$ \\
\hline
\end{tabular}

Quadro 2: Classificação dos verbos pela função. (p. 163-164).

O verbo "dizer" é considerado pelo autor com um "coringa", pois pode ser usado em todas as funções elencadas no referido quadro. Marcuschi (2007) ainda revela que os verbos introdutores de opinião têm um grande papel na economia jornalística, já que eles têm uma função direta na construção do discurso relatado e reordenam o texto, preservando a sua ação. Para tanto, três aspectos são levados em consideração:

\footnotetext{
a) Os verbos exercem uma ação sobre o dito relatado;

b) Os verbos organizam o discurso relatado numa ordem e numa estrutura própria;
} 
c) $\quad \mathrm{Na}$ reordenação discursiva que processam, esses verbos preservam sua ação interpretativa anterior. (p. 166).

Travaglia (2003) divide os verbos dicendi em três tipos, segundo a sua funcionalidade: introdução de falas; tipos de produção (perguntar, responder) e, por último, perspectivas da fala (segredar, acalmar).

Já Nascimento (2006) defende a tese de que a notícia, apesar de sua dita neutralidade, carrega em si várias formas de argumentação como: "polifonia, modalização, através de verbos dicendi, os operadores argumentativos, o arrazoado por autoridade, entre outras" (pág. 72). A estratégia de modalização para este autor se dá por meio da polifonia e do uso de verbos dicendi. O linguista também defende um quadro de verbos mais sintético, que poderemos ver a seguir:

\begin{tabular}{|l|l|}
\hline $\begin{array}{l}\text { 1. não-modalizadores, ou de primeiro } \\
\text { grupo }\end{array}$ & $\begin{array}{l}\text { Dizer, falar, perguntar, responder, } \\
\text { concluir, etc. }\end{array}$ \\
\hline $\begin{array}{l}\text { 2. } \begin{array}{l}\text { modalizadores ou de segundo } \\
\text { grupo }\end{array} \\
\text { Acusar, protestar, afirmar, declarar, etc. }\end{array}$ \\
\hline
\end{tabular}

Tabela 3: Verbos dicendi (p. 80).

Dessa forma, Nascimento (2006) conclui que os verbos dicendi "não são apenas meros introdutores de discurso ou relato. Além dessa função, eles são portadores de sentido e podem indicar o modo como esse discurso ou relato pode ser lido" (p. 84). Apesar de o autor dizer que essa tabela é mais sintética, portanto caberia melhor na aplicação da análise de textos jornalístico, levamos em consideração para a análise a tabela feita pelo professor Marcuschi por ela dar maior respaldo para uma análise do discurso citado e os vários tipos de verbos dicendi, seus usos e significados dentro do texto.

Segundo Grillo (2001), esses verbos são denominados verbos de elocução e têm como função principal marcar a presença do discurso citado, de resumir o sentido geral do discurso proposto, de dar condições para sua recepção e, por fim, de organizar a estrutura argumentativa do texto, principalmente no gênero notícia.

Para Cervoni (1989), os verbos dicendi fariam parte das modalidades impuras e os tipos de modalização seriam divididos em: 
Epistêmica: Considerações sobre o valor da verdade do seu conteúdo proposicional;

Deôntica: O conteúdo proposicional do enunciado deve ou precisa ocorrer;

Avaliativa: Uma avaliação ou juízo de valor a respeito do seu conteúdo proposicional... (pág. 75).

O conceito de polifonia dentro da análise do discurso é trabalhado pela divergência, pois há uma simultaneidade de vozes dentro de uma mesma notícia; no entanto, elas não convergem para uma mesma tonalidade. Pelo contrário, elas destoam para tornar o texto polifônico e divergente, dando maior credibilidade ao texto, pois assim se contemplam as diferentes opiniões referentes ao assunto tratado. É esse processo que será observado na análise feita no próximo capítulo: as vozes que divergem e confabulam para a construção e argumentação das notícias sobre educação.

Buscamos ainda saber como esse discurso inserido na notícia vem corroborar com ou destoar de uma opinião oficial sobre educação. Desse modo, pretendemos analisar linguisticamente como se comporta tal fenômeno, sabendo que "um texto nunca é neutro em si” (Maingueneau, 2002). A própria construção textual pode revelar o que o enunciador expressa como opinião favorável ou não à determinada questão, mesmo que isso não ocorra de maneira explícita por se tratar de notícia de jornal.

Segundo Erbolato (2002), “(...) o jornal deve informar o máximo possível e com neutralidade, a fim de que cada leitor possa ser seu próprio intérprete e seu próprio editorialista" (p.36-37). O autor ainda afirma que a interpretação de uma notícia é uma superdefinição, não devendo ser realizada em uma simples notícia que tem de ser direta e relativamente curta. A estrutura da notícia evidenciará, de certo modo, mesmo que velado, a opinião do jornalista, autor de tal notícia.

Assim, é importante também observar de quem é a voz trazida para o texto e que efeitos de sentido podem ser construídos a partir do trecho enunciado e selecionado. Dessa maneira, podemos perceber que a polifonia pode revelar diferentes intencionalidades, dependendo do objetivo do enunciador e do autor social por trás daquela fala.

Segundo Grillo (2001), o enunciador sempre irá dialogar com outros discursos anteriores desde que tenham o mesmo objeto como foco e isso pode ser comprovado pelas diferentes formas do discurso. Temos três tipos de uso de polifonia quanto à classificação de pertencimento do discurso. São elas, segundo Bakhtin (2006): 


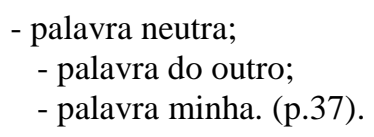

A presença do discurso citado é uma das características explícitas da polifonia, pois, conforme Grillo (2001), ela ocorre em:

(...) função do gênero da imprensa e é responsável pela identidade de alguns gêneros. Pelo seu papel de testemunha dos fatos relatados e de constituinte da imprensa como um todo e de certos gêneros em particular, o discurso citado se constitui em uma categoria descritiva para apreender (...). (p.43).

É, portanto, sob essas perspectivas que analisaremos a polifonia em notícias relacionadas à educação, publicadas pelo jornal FSP. Por fim, é preciso ressaltar aqui que, para um analista do discurso em geral, é importante que se fundamente e se constitua uma descrição das regularidades, revelando assim um paradigma. É a isso que o próximo capítulo se propõe ao analisar o corpus mais detalhadamente. 
"A confiança na palavra do outro, a aceitação reverente (a palavra autoritária), o aprendizado, as buscas e a obrigação do sentido, a concordância, suas eternas fronteiras e matizes (...) sobreposições de sentido, sobre o sentido, da voz sobre a voz, combinação de muitas vozes ... a saída para além dos limites do compreensível" (Bakhtin, 2006, p. 327) 


\section{CAPÍTULO 3: ANÁLISE DO CORPUS}

Para análise da polifonia nas notícias publicadas no jornal FSP, foram usados quadros a fim de proporcionar melhor visualização do que será analisado, principalmente, ao destacar os discursos diretos e indiretos inseridos nas notícias sobre Educação nas mais diferentes décadas. Dessa maneira, os quadros se fazem necessários e serão numerados de acordo com as notícias que estão transcritas, integralmente nos anexos.

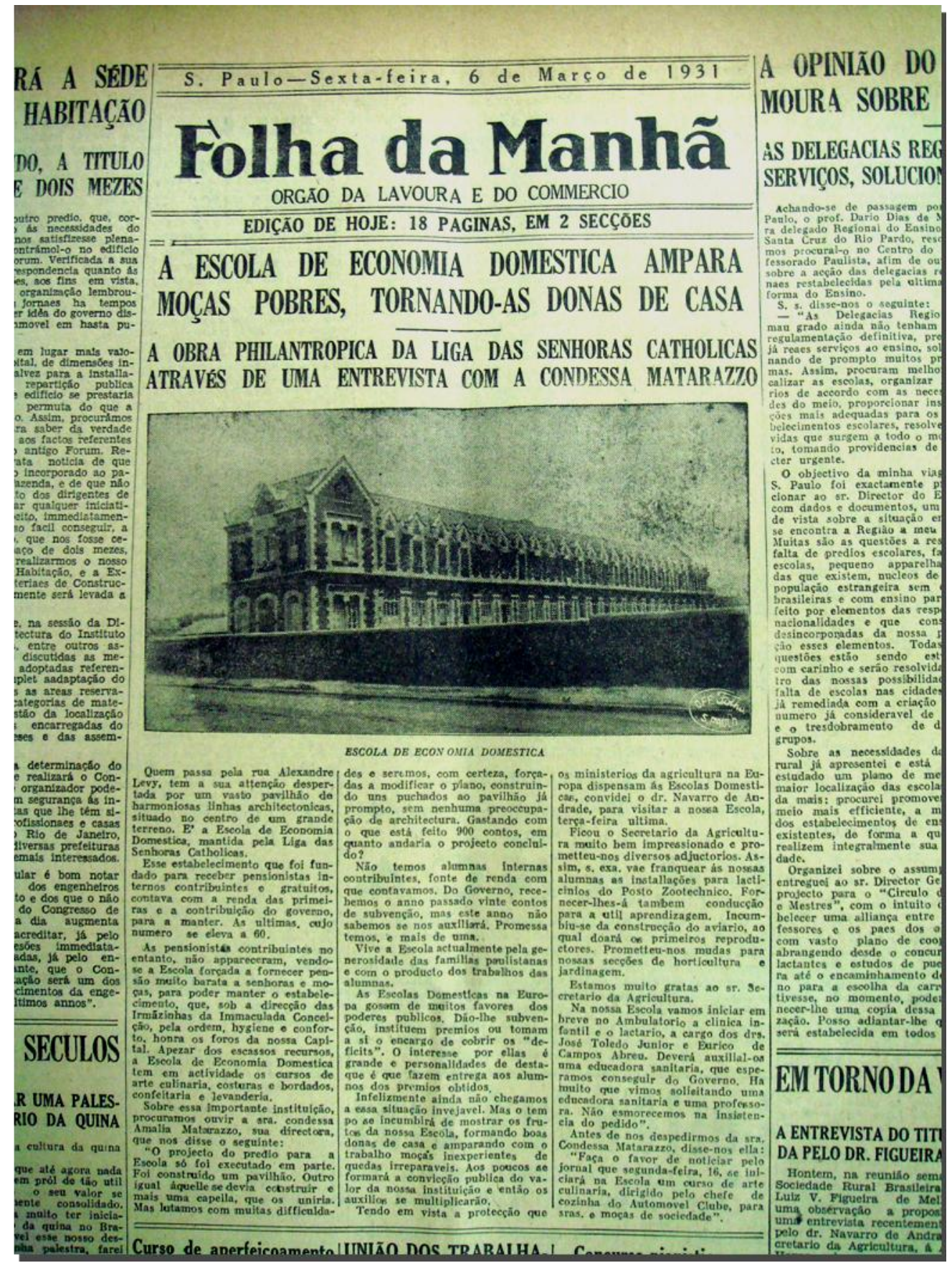

Fig. 5- Foto da primeira notícia aqui analisada do início da década de 1930. 


\section{1 - Notícias das décadas de 1930 e 1940}

NOTÍCIA 1- 6/03/1931

A ESCOLA DE ECONOMIA DOMESTICA AMPARA MOÇAS POBRES, TORNANDO-AS DONAS DE CASA

A OBRA PHILANTROPICA DA LIGA DAS SENHORAS CATHOLICAS ATRAVÉS DE UMA ENTREVISTA COM A CONDESSA MATARAZZO

\begin{tabular}{|c|c|c|}
\hline $\begin{array}{l}\text { Tipo de } \\
\text { discurso } \\
\text { empregado }\end{array}$ & $\begin{array}{lr}\text { Ator social } \\
\text { atribuído ao } \\
\text { discurso }\end{array}$ & Reprodução do trecho \\
\hline $\begin{array}{l}\text { Discurso } \\
\text { direto }\end{array}$ & $\begin{array}{l}\text { Condessa } \\
\text { Amália Cintra } \\
\text { Ferreira } \\
\text { Matarazzo }\end{array}$ & 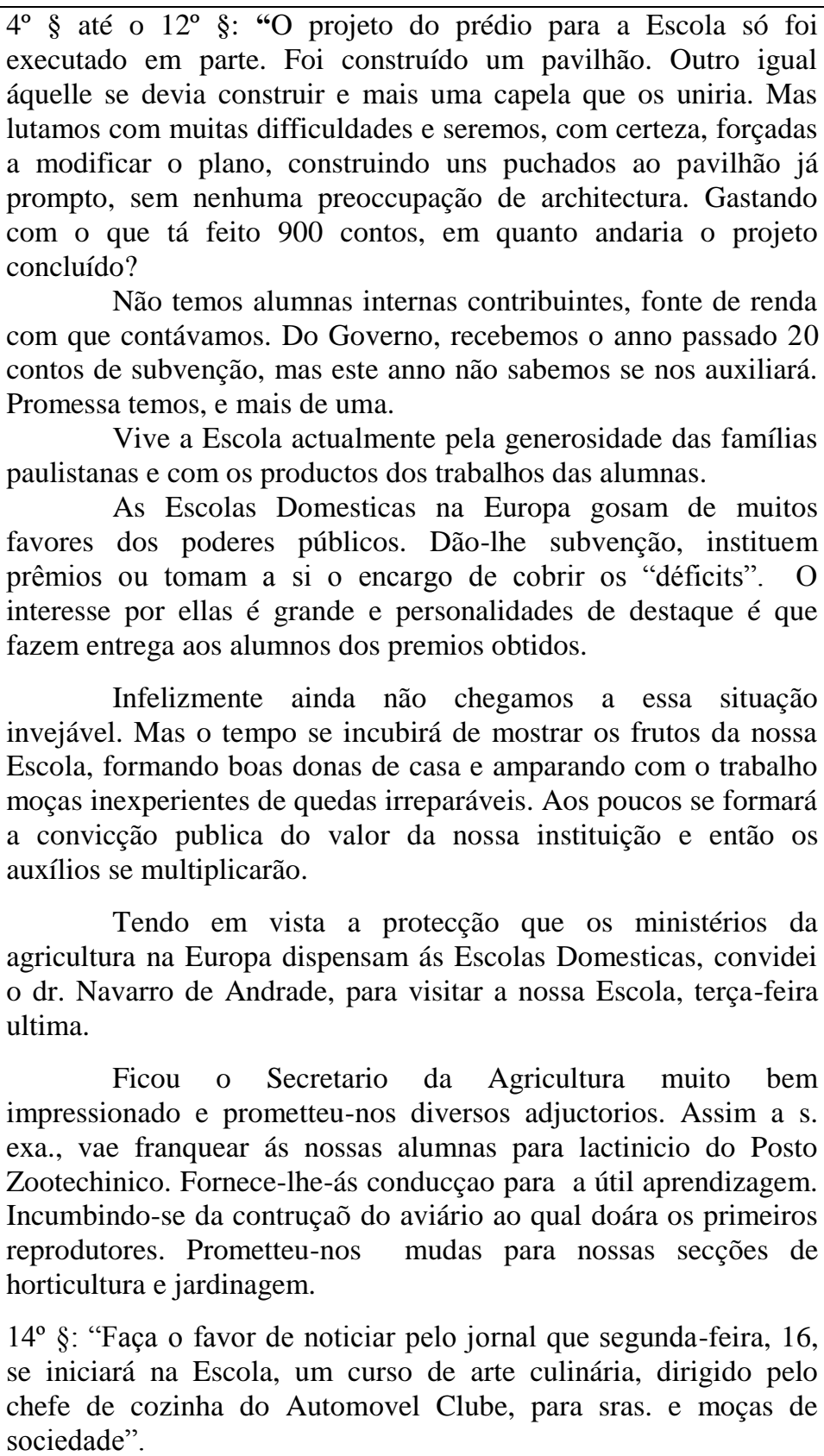 \\
\hline
\end{tabular}


Neste texto podemos notar que a partir do quarto parágrafo até próximo do seu fim temos a primeira, única e contínua inserção de discurso citado que é o direto. A voz de autoridade desse discurso é a da condessa Amália Cintra Ferreira Matarazzo, mais conhecida apenas como Amália Matarazzo, uma dama respeitada e detentora de uma imagem fortemente positiva pela sua benevolência e projetos sociais. Ela era esposa do conde Andre Matarazzo e também diretora da escola de economia doméstica. A condessa ficou conhecida tanto aqui quanto na Itália por seu trabalho beneficente próobras assistenciais.

Quanto à polifonia, podemos perceber, como já foi comentado, que existe uma única voz de autoridade ligada a um membro de uma família tradicional de São Paulo. A declaração se aproxima muito mais de um relato sobre as atividades oferecidas na Escola de Moças do que a uma efetiva voz introduzida para produzir a devida autenticidade ao texto. Dessa maneira, a voz da Condessa Amália Matarazzo é a notícia em si, deixando em segundo plano a voz do jornalista, normalmente considerado o enunciador principal, detentor do poder no gênero notícia. A voz da Condessa relata e não polemiza. A citação não tem a função de distanciar o enunciador do que é dito, mas sim de promover a voz de autoridade, no caso aqui, de Amália Matarazzo e a sua benevolência com as moças pobres.

No entanto, podemos perceber também a voz dentro de uma voz, ou seja, há o discurso direto de Amália e tal autora usa a voz do Secretário da Agricultura, ela se vale do ator social de um representante do governo em seu discurso direto nos $10^{\circ} \mathrm{e} 11^{\circ}$ parágrafos. Ela diz que ele ficou impressionado e prometeu auxílio para o projeto. Tal estratégia seria do uso de autoridade por outra autoridade social, pois a condessa Amália Matarazzo em si é uma autoridade social devido a sua posição e aos seus trabalhos sociais e ela evoca outra autoridade governamental que é o Ministro da Agricultura da época.

Ao final da notícia, depois de uma explicação do enunciador (o jornalista), temos outra inserção do discurso direto com a mesma autora atribuída ao discurso anterior, a condessa Amália Matarazzo. No caso, ela faz uma espécie de propaganda do curso de culinária que se iniciará em sua Escola de Moças. 
NOTÍCIA 2 - 06/04/1931

O MAGISTÉRIO DE SÃO PAULO O CRITERIO PARA AS PROMOÇÕES

\begin{tabular}{|c|c|c|}
\hline $\begin{array}{l}\text { Tipo de } \\
\text { discurso } \\
\text { empregado }\end{array}$ & $\begin{array}{lr}\text { Ator social } \\
\text { atribuído ao } \\
\text { discurso }\end{array}$ & Reprodução do trecho \\
\hline $\begin{array}{l}\text { Discurso } \\
\text { indireto }\end{array}$ & $\begin{array}{ll}\text { Projeto } & \text { de } \\
\text { Critério } & \text { de } \\
\text { Promoções } & \text { no } \\
\text { Magistério } & \end{array}$ & 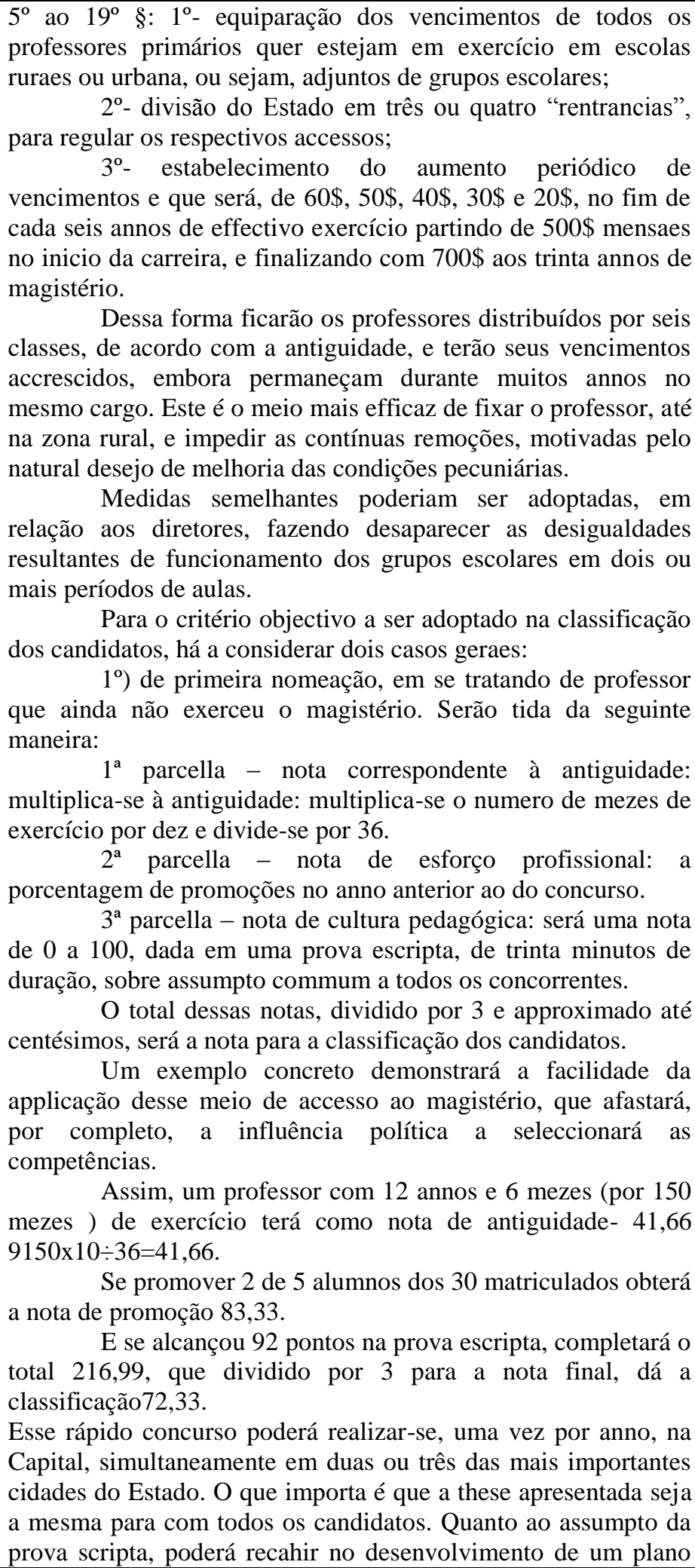 \\
\hline
\end{tabular}




\begin{tabular}{|l|l|l|}
\hline & $\begin{array}{l}\text { de aula, designado na ocasião, ou ser constituído de uma série de } \\
\text { "testes", semelhantes aos que há annos, se empregam, no Centro } \\
\text { de Saúde Modelo, para a classificação dos professores que se } \\
\text { candidatam ao curso de educadores sanitários. }\end{array}$ \\
\hline
\end{tabular}

Na primeira linha do texto, já podemos notar a FSP se auto-intitulando como voz de autoridade, ao referir-se a uma notícia anterior publicada nesse mesmo jornal por meio do enunciado:

Conforme foi noticiado, realizou-se hontem á noite, na sede do Centro do Professorado Paulista, a reunião convocada especialmente para a discussão do critério das promoções no magisterio, a ser adoptado pelo Estado de São Paulo.

O trecho "Conforme foi noticiado" é categorizado por Grillo (2001) como sendo um modalizador, pois expressa - potencialmente posposto a esta partícula - quem é o autor do discurso. Outro fator relevante que poderíamos observar é a estratégia da FSP de se colocar como uma voz de autoridade criando para si mesma uma imagem de um jornal idôneo e atrelado à verdade absoluta. Esse tipo de estratégia é comum até os dias de hoje e, segundo o Manual da Redação da FSP, explica-se pela necessidade de padronização. No entanto, tal padronização não existia na década de 1930, nem ao menos as páginas dos jornais eram numeradas com um parâmetro fixo. Disso podemos concluir que o uso estratégico de auto-citação da FSP como um argumento de autoridade é usado como status oficial de uma "auto-imagem super-positiva" que pode ter fomentado o crescimento da FSP por todos seus leitores.

A partir do $5^{\circ}$ parágrafo até o final do texto o enunciador relata os assuntos que foram discutidos e acertados durante a reunião de critérios para promoção do Magistério e ele elenca em seguida resumidamente tudo que foi contemplado neste projeto, o qual os professores aprovaram com louvor.

O projeto foi escrito por Cymbelino de Freitas, no entanto, o enunciador fez um discurso direto do projeto para elencar as medidas propostas e não a fala de seu autor. Segundo Van Leeuwen (1997), esse fenômeno linguístico é chamado de autonomização do enunciado, processo no qual o autor é substituído pelo documento, ou seja a figura humana do professor Cymbelino Freitas foi substituído por seu enunciado (Projeto de Reforma do Magistério). Isso pode ter ocorrido pelo fato de o enunciador ter pretendido dar maior credibilidade ao seu texto, assumindo como ator social principal um documento oficial ao invés de um ator social. 
NOTÍCIA 3 - 18/04/1931

AGGRAVANDO, EXCESSIVAMENTE, AS TAXAS DOS CURSOS SUPERIORES, O GOVERNO TRANCA SUAS ESCOLAS Á MOCIDADE QUE NÃO NASCEU EM BERÇO DE OURO"

\begin{tabular}{|c|c|c|}
\hline $\begin{array}{l}\text { Tipo de } \\
\text { discurso } \\
\text { empregado }\end{array}$ & $\begin{array}{lr}\text { Ator } & \text { social } \\
\text { atribuído } & \text { ao } \\
\text { discurso } & \end{array}$ & Reprodução do trecho \\
\hline \multirow[t]{2}{*}{$\begin{array}{l}\text { Discurso } \\
\text { indireto }\end{array}$} & $\begin{array}{l}\text { Estudantes de } \\
\text { Medicina }\end{array}$ & $\begin{array}{l}5^{\circ} \text { e } 6^{\circ} \S \text { : Em virtude da situação em que se acham os } \\
\text { estudantes de medicina, ouvimos vários rapazes sobre o } \\
\text { assumpto e estes nos affirmaram que estavam ignorando tudo } \\
\text { o que se passava e somente foram conhecedores do facto há } \\
\text { dois dias, o que os deixou "groggy", ao saberem do tal } \\
\text { augmento exaggeradissimo das taxas. } \\
\text { Em todo o caso, - accrescentaram-nos - que o pensamento } \\
\text { dominante entre os demais collegas era promover-se uma } \\
\text { acção uniforme da Federação Universitaria, de modo que os } \\
\text { elementos universitários apparecessem em bloco, deante do } \\
\text { governo. } \\
19^{\circ} \text { §: Referiram-se os jovens estudantes ao caso das taxas } \\
\text { exigidas pela reforma do ensino, alegando que a situação em } \\
\text { que vivem alguns acadêmicos, não lhes permitte pagar tão } \\
\text { excessiva taxa. }\end{array}$ \\
\hline & $\begin{array}{lr}\text { Secretário } & \text { do } \\
\text { Ministro } & \text { da } \\
\text { Educação, o } & \text { Sr. } \\
\text { Rodrigo de } & \text { Melo }\end{array}$ & $\begin{array}{l}19^{\circ} \text { §: O Sr. Rodrigo de Mello Franco declarou, em nome do } \\
\text { ministro, que este já havia resolvido, em parte, o caso, } \\
\text { aumentando o numero de matriculas gratuitas e creando, } \\
\text { mesmo o que elle denominou "compromisso de honra", para } \\
\text { os estudantes que não tenham recursos para iniciar ou } \\
\text { continuar os estudos. } \\
20^{\circ} \S \text { : O Sr. Rodrigo Mello Francisco deu, então, todas as } \\
\text { explicações que lhe cabiam, affirmando, mesmo, que o Sr. } \\
\text { Francisco Campos não tivera intuito de menosprezar esse } \\
\text { estabelecimento, que é, sem duvida, dos mais dignos e onde o } \\
\text { ensino é professado com a maior efficiencia e moralidade }\end{array}$ \\
\hline $\begin{array}{l}\text { Discurso } \\
\text { direto }\end{array}$ & $\begin{array}{l}\text { Portaria aprovada } \\
\text { pelo Ministro da } \\
\text { Educação, Sr. } \\
\text { Francisco } \\
\text { Campos }\end{array}$ & $\begin{array}{l}24^{\circ} \text { ao } 26^{\circ} \S: 1^{\circ} \text { ) - o serviço de publicidade que compete á } \\
\text { Directoria Geral de Informações, Estatistica e Divulgação se } \\
\text { fará: } \\
\text { a) pelos annexos ao relatório annual do ministro; } \\
\text { b) pelo annuario estatístico da Educação e Saude Publica; } \\
\text { c) pelo boletim official do ministério, que será publicado } \\
\text { trimestralmente: } \\
\text { d) pór opusculos avulsos dedicados a assumptos espectaes; } \\
\text { e) por meio de communicados semanaes á imprensa; } \\
\text { f) por pedido da Informações que forem dirigidos ou } \\
\text { encaminhodos a repartição com relação aos assumptos } \\
\text { superintendidos por este ministério. } \\
\left.2^{\circ}\right) \text { - Todas as repartições e Instituições que compõem o } \\
\text { ministério deverão contribuir para a efficiencia deste serviço, } \\
\text { pela forma seguinte: } \\
\text { a) Collaborando com a Directoria de Informações. Estatistica } \\
\text { e Divulgação, pelo modo que lhes for solicitado, no preparo e } \\
\text { execução das pesquizas, estatísticas e inquéritos, outros que se } \\
\text { houverem de effectuar e que tiverem correlação com os } \\
\text { programmas: } \\
\text { b) fornecendo, subscriptos pelos respectivos directores ou }\end{array}$ \\
\hline
\end{tabular}




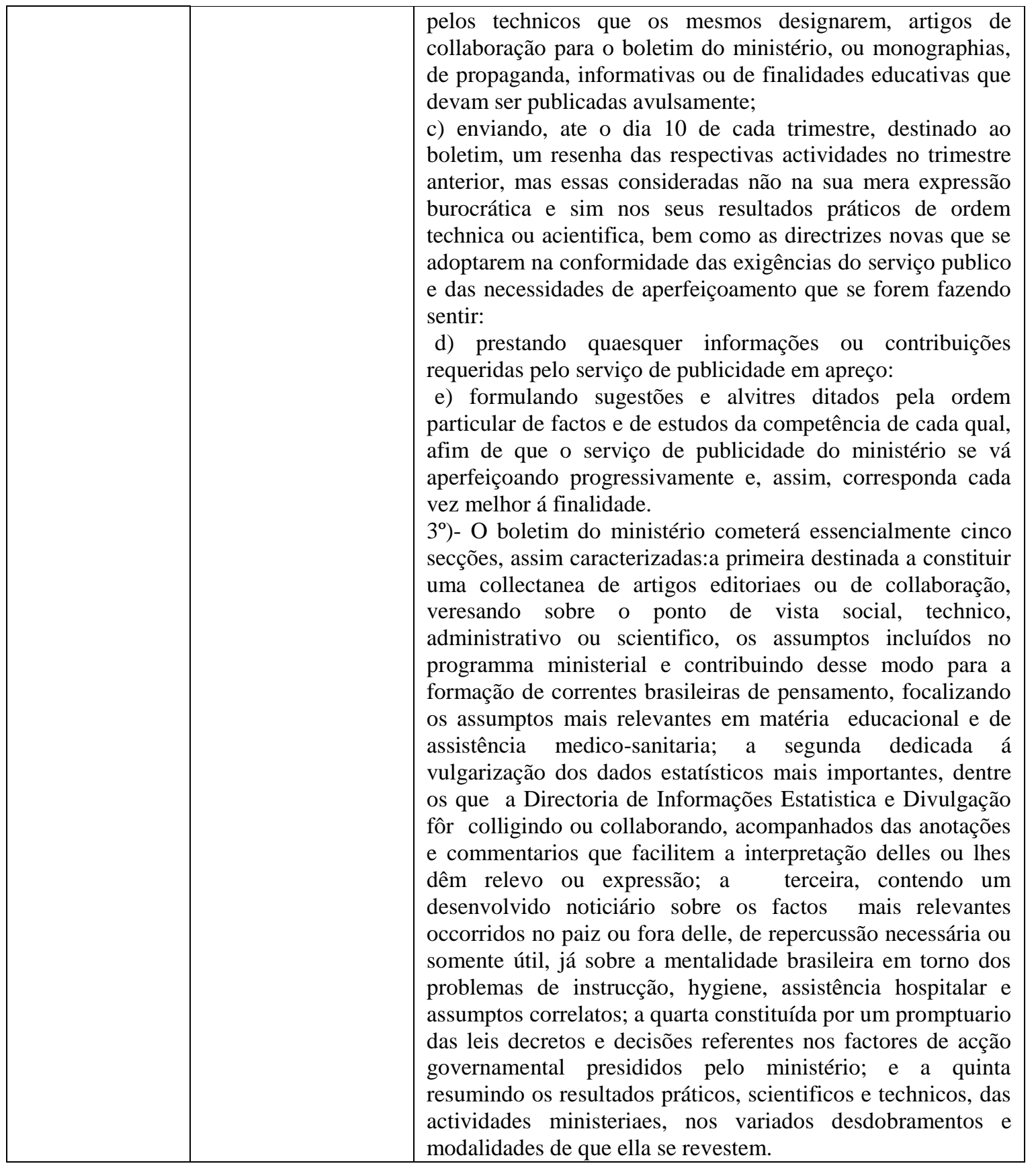

Temos, neste texto, uma questão acerca de quem se refere a voz desse nós oculto em "ouvimos vários rapazes" no $5^{\circ}$ parágrafo. Esse nós pode estar impregnado de toda a equipe jornalística que participou na construção da notícia ou pode ter sido apenas um uso de distanciamento para que não se utilizasse a primeira pessoa do singular (eu), o que não seria muito adequado para o gênero notícia.

Outro questionamento que se pode fazer é quem são esses "vários rapazes", qual o nome, sobrenome e idade deles? Nesse enunciado, as vozes se apresentam um tanto 
quanto obscuras, os estudantes são elencados como uma dissimulação por sinédoque ${ }^{10}$, que consiste em globalizar "alguns estudantes" por "todos os estudantes" a partir de alguns entrevistados ampliar o escopo de uma entrevista como se a opinião de um estudante apenas pudesse abarcar a de todo o corpo discente.

Por sua vez, temos o discurso indireto reproduzido a seguir que confirma e consolida a análise do parágrafo anterior:

Em todo o caso,-accrescentaram-nos - que o pensamento dominante entre os demais collegas era promover-se uma aç̧ão uniforme da Federação Universitaria, de modo que os elementos universitários apparecessem em bloco, deante do governo.

O trecho anterior reforça o que foi dito, pois no $6^{\circ}$ parágrafo temos o acréscimo da voz de outro rapaz que não foi devidamente identificado no $5^{\circ}$ parágrafo e que afirma ser dominante o "pensamento dos demais colegas". Seria o pensamento dominante relativo a quantas pessoas do grupo?

Na retranca intitulada $O s$ acadêmicos da educação, no $2^{\circ}$ parágrafo temos um excerto, reproduzido abaixo, em que a voz de autoridade é do Sr. Rodrigo de Mello Franco, secretário do ministro da Educação vigente nesse período:

O Sr. Rodrigo de Mello Franco declarou, em nome do ministro, que este já havia resolvido, em parte, o caso, aumentando o numero de matriculas gratuitas e creando, mesmo o que elle denomonou "compromisso de honra", para os estudantes que não tenham recursos para iniciar ou continuar os estudos.

O $5^{\circ}$ parágrafo corrobora a voz de autoridade de Mello Franco, que se apoia na imagem de Francisco Campos (Ministro da Educação) para explicar o problema das cobranças, ditas indevidas por parte dos estudantes de medicina:

O Sr. Rodrigo Mello Francisco deu, então, todas as explicações que lhe cabiam, affirmando, mesmo, que o Sr. Francisco Campos não tivera intuito de menosprezar esse estabelecimento, que é, sem duvida, dos mais dignos e onde o ensino é professado com a maior efficiencia e moralidade.

Nos dois trechos anteriores, podemos perceber quem são os atores sociais e por serem oficiais são devidamente qualificados e enunciados. Desse modo temos o Ministro da Educação, o senhor Francisco Campos, e o seu secretário, o senhor Rodrigo de Mello Franco. Podemos concluir que as formas como foram definidos o ator social

\footnotetext{
${ }^{10}$ Conceito trabalhado na análise de Resende e Ramalho (2006) na esteira da Thompson (1995).
} 
"estudantes" com o englobamento de "todos os estudantes", e, a individualização dos dois atores sociais oficiais presentes no texto confabulam para um prestígio destas vozes oficiais e uma sublimação, uma diminuição e diluição das vozes de protesto daqueles estudantes.

Outro fator importante a ser analisado aqui é a introdução do discurso citado direto sobre o projeto aprovado pelo Ministro da Educação, Francisco Campos: "RIO, 17 (H) - O Sr. Ministro da Educação approvou, hoje, uma portaria determinando que:"

Após o trecho elencado acima, o texto é seguido do $22^{\circ} \S$ até o final somente sobre a organização do Ministério da Educação. Os verbos introdutórios de opinião "approvou" e "determinando", são interessantes de serem analisados, pois segundo Marcuschi (2007, p.163) ambos os verbos poderiam fazer parte dos "verbos indicadores de posições oficiais e afirmações positivas". O que corrobora com a posição oficial desses atores oficiais.

NOTÍCIA 4 - 18/03/1933

COMO TEM SIDO RECEBIDO A BANDEIRA PAULISTA DE ALPHABETIZAÇÃO.

A PALAVRA DO DR. EURICO DE GÓES A RESPEITO - UMA INTERESSANTE CONFERENCIA.

\begin{tabular}{|c|c|c|}
\hline $\begin{array}{l}\text { Tipo de } \\
\text { discurso } \\
\text { empregado }\end{array}$ & $\begin{array}{l}\text { Ator social } \\
\text { atribuído } \\
\text { ao discurso }\end{array}$ & Reprodução do trecho \\
\hline $\begin{array}{l}\text { Discurso } \\
\text { direto }\end{array}$ & $\begin{array}{l}\text { Dr. Eurico } \\
\text { Góes }\end{array}$ & $\begin{array}{l}2^{\circ} \S \text { até } 4^{\circ} \S \text { : - "Recebi a Bandeira de alma aberta, ou com toda a } \\
\text { larga sympathia que merecem os nobres empreendimentos. } \\
\text { A.B.P.A. está incontestavelmente nesse caso. Ensinar o povo a ler, } \\
\text { alphabetizai-o, Instrui-lo - é por, a primeira e a mais elevada missão } \\
\text { dos governos e das nacionalidades. Ė como que fazer o sol inundar } \\
\text { de luz uma floresta, antes mergulhada na sombra. } \\
\text { Tornam-se, naturalmente, melhor apparelhadas para a } \\
\text { concorrência mundial as nações onde a instrucção popular é mais } \\
\text { diffundida ou mais perfeita. Olhem-se os exemplos dos Estados } \\
\text { Unidos, da Allemanha, da Inglaterra, da Suissa, etc. } \\
\text { Reconheço que o programma da Bandeira é devéras vasto } \\
\text { e complexo. Será necessário desenvolver grande propaganda, } \\
\text { grande energia organizada, grande continuidade de ação para } \\
\text { conseguir os seus desideratos? Contribuição do povo, por si só? } \\
\text { Talvez não baste! O extenso e variado programma das } \\
\text { administrações publicas, não so do Estado, como dos municípios. } \\
\text { Principalmente dos municípios. } \\
6^{\circ} \S \text { até } 16^{\circ} \S \text { - "O plano de idealização, ou de meios de execução, } \\
\text { pertence mais a Bandeira do que a mim. Fui, segundo me } \\
\text { informaram, apenas escolhido membro da commissão das } \\
\text { bibliothecas municipaes ou populares. Darei de bom grado, o } \\
\text { concurso que me for permitido prestar. Em chegando o momento, } \\
\text { estou prompto a contribuir com a collaboração precisa. } \\
\text { Nada se faz sem a base econômica ou os fundos } \\
\text { indispensáveis, em cada esphera de concretização utilitária. }\end{array}$ \\
\hline
\end{tabular}




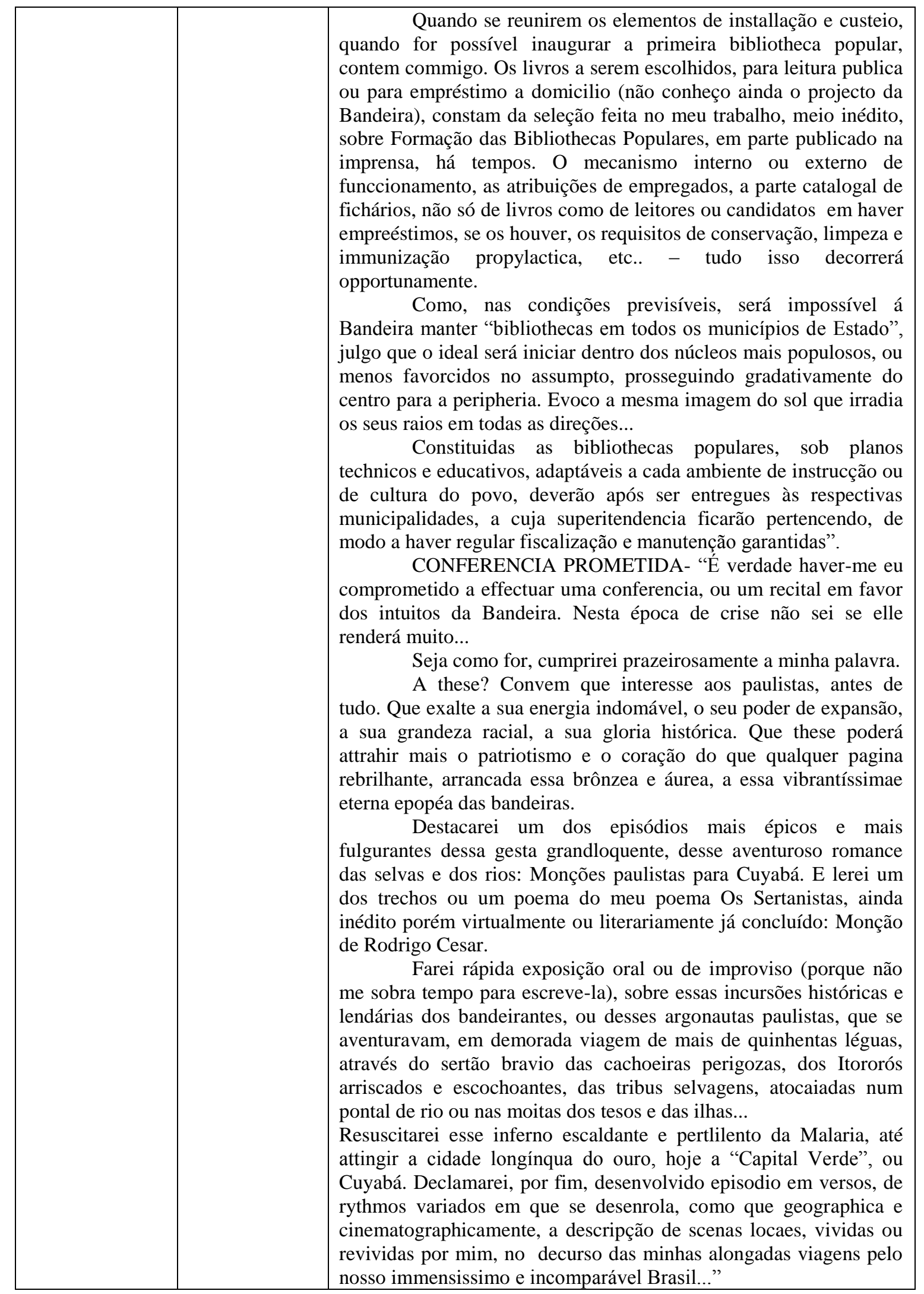

Esse texto apresenta a estrutura comum às primeiras notícias publicadas na década de 1930, pois o discurso direto começa no segundo parágrafo e segue como se 
fosse uma carta ou depoimento do Dr. Eurico, em que a ênfase no "eu" e o vangloriar-se são marcantes ao longo do discurso, descrevendo os feitos da Bandeira Paulista de Alfabetização. Cabe notar que o texto é, de modo geral, constituído pelo discurso direto, cabendo à voz do jornalista apenas o primeiro parágrafo que apresenta a simples alusão à fala do Dr. Eurico Gaspar. Assim, no primeiro parágrafo da notícia, temos: "Falandonos a propósito da Bandeira Paulista de Alphabetização, o Dr. Eurico de Góes teve as seguintes palavras:"

Outro ponto importante a ser observado é que o jornalista faz uso de retrancas, no entanto, continua com o discurso direto de Eurico. Tais retrancas serviriam apenas para elencar e dividir os assuntos tratados pela figura oficial e que foram proferidas em seu discurso. Desse modo, a voz que prevalece no texto é introduzida pelo discurso direto de um único ator social que é de prestígio e oficial. Não há, portanto, uma voz destoante ou que polemiza frente à voz de autoridade do Dr. Eurico de Góes. Para construir a notícia, o jornalista limita-se a transcrever o que foi dito pela autoridade, não contesta se suas propostas são viáveis ou se outras pessoas presentes naquela conferência lhe davam todos os créditos devidos, não há polemização, problematização ou ao menos vozes destoantes quanto ao projeto da Bandeira Paulista de Alfabetização.

\section{NOTÍCIA 5- 06/03/1934}

HÁ FALTA DE ESCOLAS PRIMARIAS NA ALTA PAULISTA.

\begin{tabular}{|c|c|c|}
\hline $\begin{array}{l}\text { Tipo de } \\
\text { discurso } \\
\text { empregado }\end{array}$ & $\begin{array}{l}\text { Ator social } \\
\text { atribuído ao } \\
\text { discurso }\end{array}$ & Reprodução do trecho \\
\hline $\begin{array}{l}\text { Discurso } \\
\text { direto }\end{array}$ & 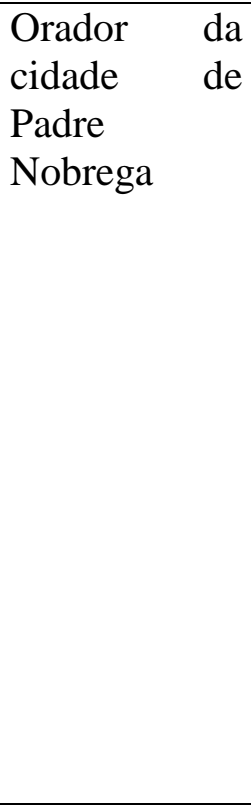 & $\begin{array}{l}5^{\circ} \text { §: "Villa caçula, que nasceu florece no recanto mais rico e } \\
\text { grandioso de Piratininga, não poderá ficar indifferente a este } \\
\text { acontecimento. Satisfeita pôr ver realizado tão grande } \\
\text { melhoramento, orgulhosa, por, embora de passagem, receber a } \\
\text { visita das altas autoridades do Estado e da directoria da } \\
\text { Companhia Paulista. Simples e humilde homenagem queremos } \\
\text { prestar aqueles que, em tão pouco tempo, muito tem feito por S. } \\
\text { Paulo: A'quelles que tem trabalhado desinteressadamente e no seu } \\
\text { grande amor é puro patriotismo por esta florão querido, ainda vive } \\
\text { e palpita o espírito dos que souberam lutar pela dignidade de São } \\
\text { Paulo. A vós compete a responsabilidade de um porvir melhor. E } \\
\text { para que isto aconteça é necessário que a bandeira da instrucção } \\
\text { esteja hasteada em todos os pontos da terra paulista. E sabendo a } \\
\text { quem nos dirigimos, ou não tenho pejo em mostrar este bando } \\
\text { garrulo de crianças que, infelizmente são incapazes de vos saudar, } \\
\text { cantando o Hymno Nacional! Senhores, nesta passagem tão } \\
\text { rapidalança e os olhos para estas crianças immersas na treva da } \\
\text { ignorância. Ajudas, eu vos peço em nome desta população, para } \\
\text { que o mais depressa possivel tremule, como sempre gloriosa e } \\
\text { invicta, na sacada de uma escola, a bandeira paulista"! }\end{array}$ \\
\hline
\end{tabular}




\begin{tabular}{|c|c|c|}
\hline \multirow[t]{2}{*}{$\begin{array}{l}\text { Discurso } \\
\text { indireto }\end{array}$} & $\begin{array}{l}\text { Moradores de } \\
\text { Marília }\end{array}$ & $\begin{array}{l}9^{\circ} \S: \text { Em Marilia novamente, os repórteres receberam de } \\
\text { numerosos commerciantes e de varias pessoas da sociedade local } \\
\text { as incumbencia de pelos jornaes, falaram do triste estado do } \\
\text { edifício do grupo escolar, afim de que o governo do Estado volte } \\
\text { suas vistas para aquella região da Alta Paulista que trabalha e } \\
\text { produz, sem receber os benefícios da assistência social. }\end{array}$ \\
\hline & $\begin{array}{l}\text { Repórteres da } \\
\text { FSP }\end{array}$ & $\begin{array}{l}10^{\circ} \S \text { ao } 11^{\circ} \S \text { : Da nossa parte envidávamos todos os esforços para } \\
\text { satisfazer o desejo dos marilenaria. Em uma reunião encontramo- } \\
\text { nos com o prof. Luiz da Motta Mercier, director geral do Ensino, } \\
\text { e, marcou-nos uma entrevista em seu gabinete de trabalho. Fomos } \\
\text { pontuaes, mas o prof. Mercier não cumpriu o compromisso que } \\
\text { comnosco assumira. Estivemos dois dias seguido na Diretoria } \\
\text { Geral sem com tudo, logramos falar com o prof. Motta Mercier. } \\
\text { No primeiro dia, fomos informados por um dos seus auxiliares, s. } \\
\text { s. ido despachar com o secretário da Educação. No dia seguinte } \\
\text { houve, evidentemente má vontade. Fomos annunciado ao prof. } \\
\text { Motta Mercier e ficamos um tempo enorme á espera de que s. s. se } \\
\text { dignasse nos receber, até que se esgotou a nossa paciência. } \\
\text { Assim, não nos foi possível obter informações sobre se a } \\
\text { Directoria Geral pretende ou não dar escolas, que funcionam em } \\
\text { prédios pelo menos decentes. A população escolar da Alta } \\
\text { Paulista. }\end{array}$ \\
\hline
\end{tabular}

Notamos que o primeiro discurso direto que aparece dentro da retranca "Em Padre Nóbrega e Oriente" está localizado a partir da terceira linha do $2^{\circ}$ parágrafo e é anunciado pelo próprio jornalista como transcrição da fala de um representante da cidade chamada Padre Nóbrega que discursa para que haja, também, a construção de uma escola em sua cidade. No entanto, em momento algum foi enunciado quem foi este representante e qual a sua função social na cidade em questão. Apesar de este ator social não ter sido elencado, ele é de grande importância, pois é a única voz que teve a sua fala transcrita em discurso direto ao longo da notícia, não havendo qualquer outra inserção. O que houve apenas foi apresentação em discurso indireto e muito generalizada no seguinte trecho no $9^{\circ}$ parágrafo:

Em Marilia novamente, os repórteres receberam de numerosos commerciantes e de varias pessoas da sociedade local as incumbencia de pelos jornaes, falaram do triste estado do edifício do grupo escolar, afim de que o governo do Estado volte suas vistas para aquella região da Alta Paulista que trabalha e produz, sem receber os benefícios da assistência social.

Neste caso temos, então, a citação dos atores sociais: "comerciantes" e de "várias pessoas da comunidade local". Ao compararmos a informação transmitida por meio da voz do representante da cidade de Padre Nóbrega, veremos que proporcionalmente a voz de autoridade apresenta mais linhas e espaço dentro do texto ao invés daquela destinada a dizer o que a comunidade local almejava, ou seja, a voz social se sobrepõe diante da comunidade local. 
Por fim, temos o discurso (quase um relato) do que aconteceu nos dias que sucederam a visita local. Os jornalistas da FSP se prestaram a ir atrás do prof. Luiz da Motta Mercier, diretor geral do Ensino, com o intuito de relatar as instalações precárias da escola da cidade de Marília, mas dizem que após três dias de espera e procura pelo professor em seu gabinete, eles não tiveram êxito. Podemos levar em consideração vários pontos importantes: a FSP querendo sair do seu papel jornalístico e fazendo uma atuação efetiva dentro da sociedade, mas sem êxito ao final. Desse modo, a FSP quer se auto-intitular como beneficente e detentora de uma mudança social. Por isso o relato pormenorizado dos fatos sucessivos de espera e o apontamento do descaso do professor Luiz Motta para receber tais jornalistas.

NOTÍCIA 6- 06/03/1934

A ORGANIZAÇÃO DA UNIVERSIDADE DE SÃO PAULO.

\begin{tabular}{|c|c|c|}
\hline $\begin{array}{l}\text { Tipo de } \\
\text { discurso } \\
\text { empregado }\end{array}$ & $\begin{array}{lr}\text { Ator } & \text { social } \\
\text { atribuído } & \text { ao } \\
\text { discurso } & \\
\end{array}$ & Reprodução do trecho \\
\hline $\begin{array}{l}\text { Discurso } \\
\text { direto }\end{array}$ & $\begin{array}{l}\text { Dr. Christiano } \\
\text { Altenfelder, } \\
\text { secretario de } \\
\text { Educação }\end{array}$ & $\begin{array}{l}3^{\circ} \text { ao } 12^{\circ} \text { §: Possivelmente este mez - afirmou-nos s. exa. } \\
\text { será constituído o Conselho Universitário, de acôrdo com o } \\
\text { determinado no artigo } 28 \text { do decreto que creou a Universidade. } \\
\text { Já se estão realizando os sorteios dos representantes dos } \\
\text { professores cathedraticos das differentes Escolas ou } \\
\text { Faculdades. O sorteio do representante da Faculdade de Direito } \\
\text { será feito logo que seja publicado o decreto federal, que passa } \\
\text { para as mãos do Estado essa instituição e que, como é sabido, } \\
\text { já está assignado pelo chefe do governo da União. } \\
\text { O Conselho tratará de organizar o regimento interno } \\
\text { da Universidade e medidas para a sua imediata instalação. A } \\
\text { Faculdade de Direito contribuirá para esse regimento interno } \\
\text { universitário com o seu próprio, que está sendo redigido por } \\
\text { determinação nossa, pelos drs. Sampaio Doria e Mario } \\
\text { Mazagão. } \\
\text { A Faculdade de SCIENCIAS Economicas e } \\
\text { Commerciae que deve fazer parte da Universidade não será } \\
\text { creada ainda este anno. Provavelmente será no próximo anno. } \\
\text { Quanto á Escola de Bellas Artes, continuará a funcionar este } \\
\text { anno, como até agora sem fazer parte da Universidade, nella } \\
\text { ingressando também no anno vindouro. } \\
\text { O melhor das nossas attenções está voltado, agora, } \\
\text { para a organização da Faculdade de Philosophia, Sciencias e } \\
\text { Letras, que começará a funccionar em junho. } \\
\text { A viagem do dr. Theodoro Ramos está dando } \\
\text { resultados magníficos. Na Italia foram contratados } 3 \\
\text { professores, dentre os quaes duas celebridades mundiaes. São } \\
\text { elles: Luigi Fantopié, professor de Analyse, Calculo Integral e } \\
\text { Differencial, da Universidade de Bologna; G. Wataghin, da } \\
\text { Academia Militar de da Universidade de Turim, } 1^{\circ} \text { premio do } \\
\text { Concurso da Academia Pontifical de Roma, sobre } \\
\text { monographias relativas á theoria dos "quanta"; Francesco } \\
\text { Piccolo, professor de latim na Universidade de Roma e de }\end{array}$ \\
\hline
\end{tabular}




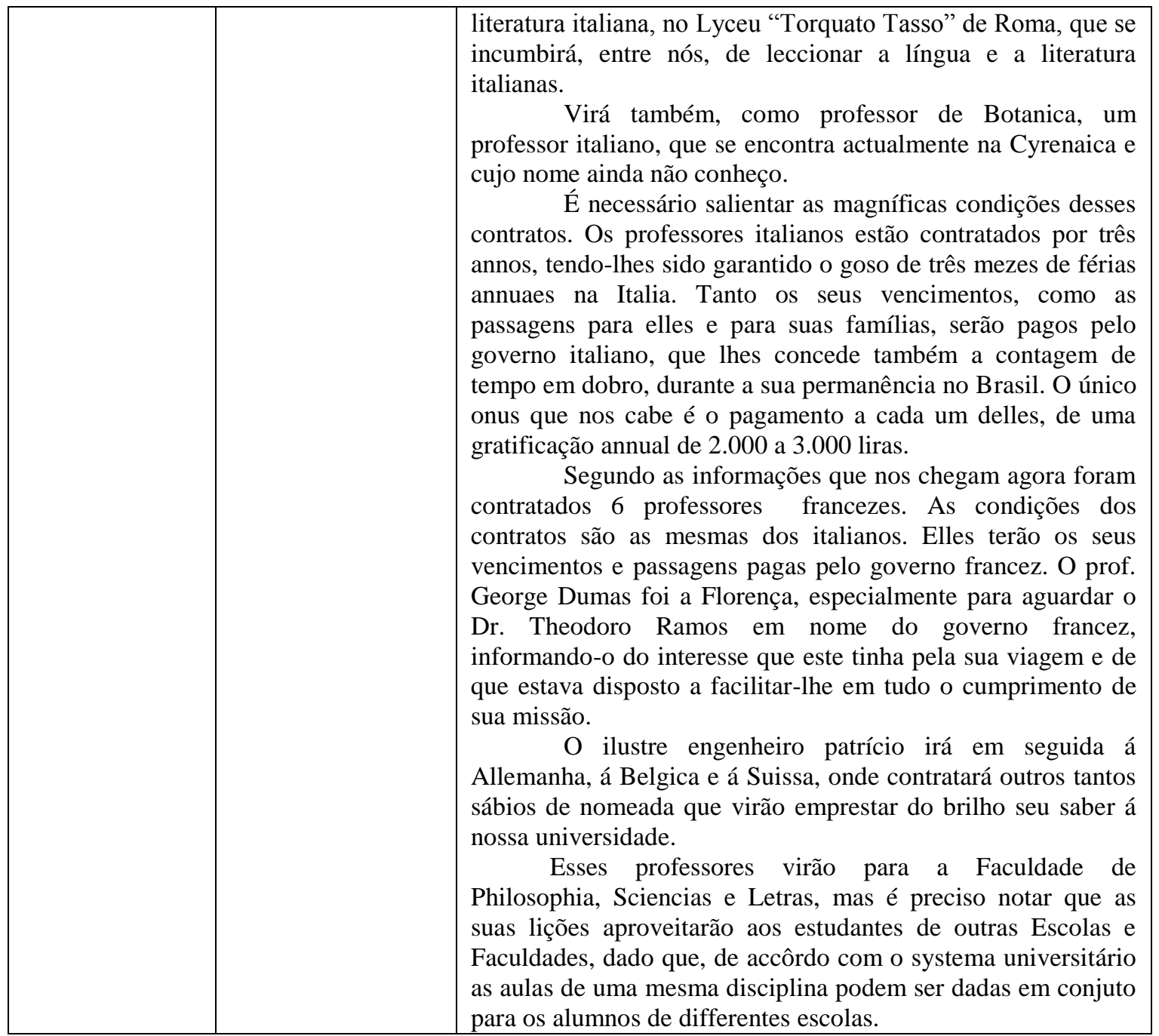

Temos no primeiro parágrafo deste texto uma introdução de todo o discurso do Secretário de Educação que se segue, assim veremos adiante: "As informações que o dr. Christiano Altenfelder, secretario de Educação, teve a gentileza de nos fornecer sobre a marcha dos trabalhadores da sua organização, são animadoras."

Ao fazermos uma seleção lexical, poderemos perceber que, quando usa o termo "gentileza" para enunciar e emoldurar o Secretário de Educação de passar as informações e que estas são "animadoras", temos como percepção a posição pró-oficial do jornalista. A voz do jornalista corrobora com os feitos de um ator oficial e detentor de poder, tanto isso é verídico que a voz do jornalista some e se dilui ao longo de todo o texto frente ao discurso do Dr. Christiano Altenfelder. Podemos notar que o texto aqui analisado a partir do terceiro parágrafo até ao final é composto pelo discurso direto, que é reiterado na primeira linha do terceiro parágrafo como vemos: "Possivelmente este mez - afirmou-nos s. exa. - será constituído o Conselho Universitário (...)” 
O autor do discurso é o secretário da Educação na época da notícia, o Dr. Christiano Altenfelder. Tal discurso tem o intuito de dissertar sobre os avanços e contratações de professores para a abertura da Universidade de São Paulo (USP). Nesse texto como em outros analisados anteriormente, não há conflito de vozes e de ideias, a voz é única: a oficial. E tudo se passa nos jornais como se tudo ocorresse sem maiores complicações, sem oposições, tudo é claro e plano chega até mesmo a ser um tanto artificial. O jornalista some de cena e apenas transcreve o que o ator oficial diz, não há um questionamento da veracidade dos fatos narrados pelo secretário de Educação.

NOTÍCIA 7 - 14/04/1942

AMPLIAÇÃO DO NOSSO SISTEMA EDUCACIONAL - CRIAÇÃO DE MAIS DOZE MIL ESCOLAS.

\begin{tabular}{|c|c|c|}
\hline $\begin{array}{l}\text { Tipo de } \\
\text { discurso } \\
\text { empregado }\end{array}$ & $\begin{array}{lr}\text { Ator } & \text { social } \\
\text { atribuído } & \text { ao } \\
\text { discurso } & \\
\end{array}$ & Reprodução do trecho \\
\hline $\begin{array}{l}\text { Discurso } \\
\text { direto }\end{array}$ & $\begin{array}{ll}\text { Titular } & \text { da } \\
\text { Secretaria } & \text { da } \\
\text { Educação, o dr. } & \text { José Rodrigues } \\
\text { Alves Sobrinho }\end{array}$ & $\begin{array}{l}3^{\circ} \S \text { ao } 7^{0} \S: \text { "A qualidade supera sem dúvida, a quantidade. } \\
\text { Estas verdades banais estão a indicar e a exigir a imperiosa } \\
\text { necessidade de promovermos, sem perda de tempo e com a } \\
\text { máxima energia, a ampliação do nosso sistema educacional, } \\
\text { infelizmente muito aquém das nossas necessidades. São Paulo, } \\
\text { pelo último recenseamento, possue } 7 \text { milhões e } 300 \text { mil } \\
\text { habitants. Nossa população escolar, fixada na proporção } \\
\text { usual de } 1800 \text { sobre aquele número, alcança o total de } \\
1.314 .000 \text { crianças. Recebem, porem, instrução primária no } \\
\text { Estado - instrução estadual, municipal e privada - } 800.000 \\
\text { alunos. O Estado, só ele, ministra instrução a } 600.000 \\
\text { escolares, divididos por 12.500 unidades. Quer isto significar } \\
\text { que existem no nosso território } 500.000 \text { crianças sem escola. É } \\
\text { portanto, premente e imprescindível a criação de mais } 12.000 \\
\text { escolas primárias para serem distribuídas pelo nosso Estado. } \\
\text { Somente na Capital, no decurso do ano passado, houve } 20.000 \\
\text { pedidos de matrículas inatendidos. A nossa Capital, só ela, } \\
\text { precisa de } 500 \text { escolas. E este numero crescerá muito se } \\
\text { considerarmos que computamos unicamente as crianças que } \\
\text { solicitaram e não obtiveram matrícula, deixando de lado } \\
\text { muitos milhares, cujos pais, ou responsáveis, por desleixo ou } \\
\text { por preverem a inutilidade dos seus esforços, nem siquer se } \\
\text { animaram a solicitar matrículas de seus filhos. Não é, assim, } \\
\text { exagerado o cálculo de mais de } 25.000 \text { crianças que, na } \\
\text { Capital, não freqüentam escolas. Para a necessidade de mais } \\
\text { de } 12.000 \text { escolas o orçamento deste ano só consignou a verba } \\
\text { de } 500: 000 \$ 000 \text { suficiente, apenas, para as } 120 \text { escolas que } \\
\text { foram disseminadas, em grande parte pelos núcleos de } \\
\text { infiltração estrangeira. } \\
\text { Urge providenciar para que cesse essa situação } \\
\text { lamentável, que vive a nos envergonhar, comprometendo a a } \\
\text { nossa capacidade e nossos foros de povo policiado. É } \\
\text { imprescindível conjugar, nesse sentido, os esforços do Estado } \\
\text { com os dos nossos municípios. O problema a todos interessa, } \\
\text { e, portanto, por todos deve e precisa ser solucionado. Allem-se } \\
\text { ambos e não poupem sacrifícios para obtenção dos recursos }\end{array}$ \\
\hline
\end{tabular}




\begin{tabular}{|l|l|l|}
\hline \multirow{10}{*}{} & $\begin{array}{l}\text { indispensáveis á debelação do mal. O Estado dispende quase } \\
1000 \text { das suas rendas, ou pouco menos de } 100.000 \text { contos de } \\
\text { réis, com o ensino primário. É pouco, muito pouco. Os } \\
\text { municípios paulistas não chegam a gastar } 600 \text { dos seus } \\
\text { orçamentos com a divulgação do ensino primário. } \\
\text { Nos Estados Unidos, di-lo eminente escritor, os } \\
\text { governos estaduais gastam em conjunto, 3900 e os municipais } \\
3500 \text { de seus orçamentos com a instrução } \\
\text { Torna-se preciso que os paulistas que se orgulham } \\
\text { muito justamente de tantas glórias, consigam eliminar do seu } \\
\text { território a carga corrosiva do analfabetismo. Não podemos, } \\
\text { nem devemos permanecer na situação humilhante em que nos } \\
\text { debatemos. Estatua o Estado a obrigação dos municípios } \\
\text { dispenderem o que for preciso para ajudá-lo, a promover a } \\
\text { redenção espiritual dos nossos patrícios. Que ninguém, pense } \\
\text { em fazer economia quando se falar em matar a ignorância de } \\
\text { nossa gente. Recordem-se todos que o que se inverte na } \\
\text { instrução e educação do povo é capital que se reproduz a } \\
\text { largos juros. Façamos, nesta hora, o solene juramento, de } \\
\text { pugnar pelo extermínio impiedoso da ignorância de nosso } \\
\text { povo. Só assim seremos bons brasileiros, merecedores da } \\
\text { grande terra que Deus nos concedeu”. }\end{array}$ \\
\hline
\end{tabular}

Logo a partir do segundo parágrafo temos esse excerto introdutório da voz de José Rodrigues Alves Sobrinho, o titular da Secretaria da Educação da época, observamos a seguir: "Disse, entre outras coisas, o Dr. José Rodrigues Alves Sobrinho:"

Podemos perceber que o excerto é seguido de um grande discurso direto, cujo ator social é o Dr. José Rodrigues. O verbo utilizado pelo enunciador foi o "dizer", que segundo Marcuschi (2007), seria uma espécie de verbo "coringa", pois ele pode ser utilizado em todas as tipologias estabelecidas pelo linguista. No entanto, ao ser seguido de um discurso citado direto extenso, podemos discernir que o ator social ao qual nos referimos se trata de uma pessoa que goza de grande prestígio social, sendo ele o titular da Secretaria da Educação.

No terceiro parágrafo, é passível de perceber o grande uso dos números que o Dr. José Rodrigues se utiliza para comprovar a evolução do sistema educacional. Segundo Lage (1985), os números e porcentagens podem ser argumentos falaciosos, na medida em que:

a) estabelecem-se falsos padrões de aferição: números de automóveis para medir o grau de desenvolvimento de países, procura emprego como índice de desempregados numa recessão prolongada etc.;

b) empregam-se unidades fora da escala do objeto aferido, para impressionar com grande números: potência de uma grande hidrelétrica em watts, metros de uma rodovia etc.;

c) comparam-se grandezas heterogêneas: tiragens de pico com tiragens médias de veículos, consumo de papel com hectares de florestas derrubadas etc.; 
d) dá-se preferência, conforme convém, a valores absolutos ou porcentagens: números relativos de produção setorial quando se instalam indústrias pioneiras, produto interno bruto como fator de comparação entre países com diferentes populações etc;

e) definem-se universos restritos para a obtenção de recordes: o melhor pianista entre os deputados, a moça mais bonita deste lado da rua etc;

f) altera-se o mecanismo de coleta ou processamento de dados: números de doentes de uma moléstia antes e depois da criação de mecanismo de controle epidemiológico, índices de preços calculados por critérios distintos, etc;

g) extrapolam-se números com leviandade: incidência de doenças cardíacas calculada para a população dos Estados Unidos e aplicada à população do Brasil etc. (p. 41).

Temos mais um texto em que o jornalista apenas "transcreve" o discurso de um ator oficial, o titular da secretaria da Educação e da Saúde, Dr. José Rodrigues Alves Sobrinho. E como vimos nas análises anteriores, não há contraposição de vozes, vozes destoantes ou divergentes. Assim, a voz oficial é única, plena e verdadeira dentro dessa notícia de jornal.

NOTÍCIA 8 - 05/03/1943

EMPENHADOS OS DIRETORES DAS ESCOLAS NORMAIS DO ESTADO NA BOA EXECUÇÃO DA REFORMA DE ENSINO A SEU CARGO.

\begin{tabular}{|c|c|c|}
\hline $\begin{array}{l}\text { Tipo de } \\
\text { discurso } \\
\text { empregado }\end{array}$ & $\begin{array}{lr}\text { Ator } & \text { social } \\
\text { atribuído } & \text { ao } \\
\text { discurso } & \end{array}$ & Reprodução do trecho \\
\hline $\begin{array}{l}\text { Discurso } \\
\text { indireto }\end{array}$ & $\begin{array}{l}\text { Sr. Israel Alves dos } \\
\text { Santos, diretor do } \\
\text { Departamento de } \\
\text { Educação }\end{array}$ & $\begin{array}{l}3^{\circ} \S \text { ao } 15^{\circ} \S \text { : Lembrando as reuniões há pouco realizadas } \\
\text { no departamento que dirige, mostrou-se muito bem } \\
\text { impressionado com a boa ordem dos trabalhos e os } \\
\text { resultados práticos desse pequeno congresso de técnicos. } \\
\text { Inicialmente, na primeira reunião, os diretores das escolas } \\
\text { normais aprovaram, por manifestação unânime, as } \\
\text { diretrizes gerais traçadas pela reforma do ensino normal. } \\
\text { Não foi esta manifestação um simples apoio formal ou } \\
\text { mera prova de acordo impensado á vontade de um chefe. } \\
\text { Ao contrário, evidenciou que a reforma veio atender a uma } \\
\text { necessidade evidente que consultava às conveniências } \\
\text { gerais de ensino e melhor correspondia aos reclamos e } \\
\text { exigências das populações do "hinterland" paulista. } \\
\text { O entusiasmo real com que os diretores dos nossos } \\
\text { estabelecimentos de ensino normal acolheram a iniciativa } \\
\text { da reforma pode ser verificado, diversas vezes, no decorrer } \\
\text { dos trabalhos aqui realizados. Aprovando a orientação geral } \\
\text { do ante-projeto de lei, mostraram, ainda, os interessados a } \\
\text { sua vontade de colaborar ativamente para que se obtenha o } \\
\text { continuo aperfeiçoamento do ensino normal bandeirante, } \\
\text { tornando o magistério primário eficiente no desempenho } \\
\text { das elevadas funções que lhe estão atribulados. } \\
\text { Comprometeram-se mesmo, todos os participantes } \\
\text { das reuniões, a empenhar o máximo de seus esforços para a }\end{array}$ \\
\hline
\end{tabular}




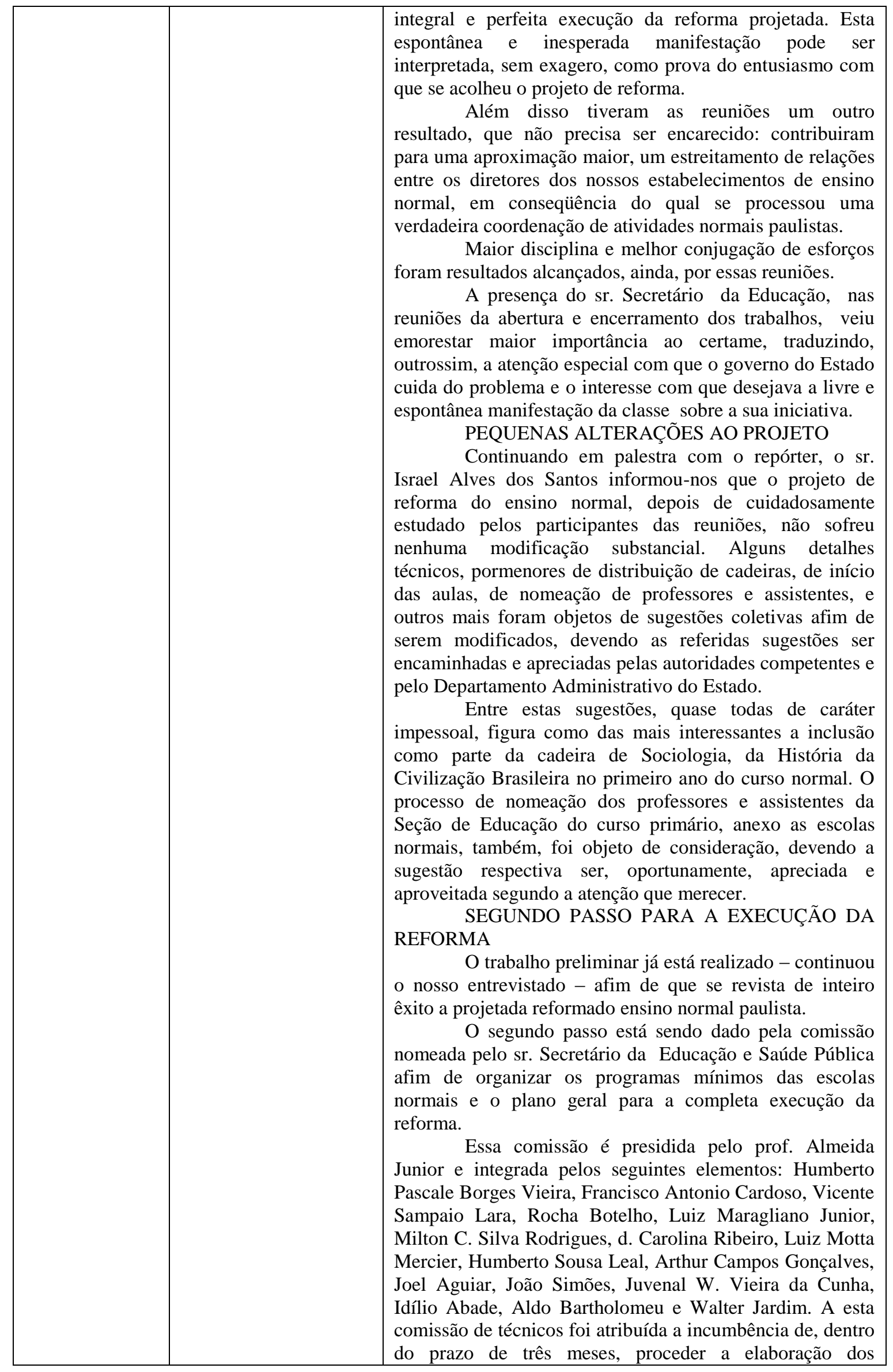




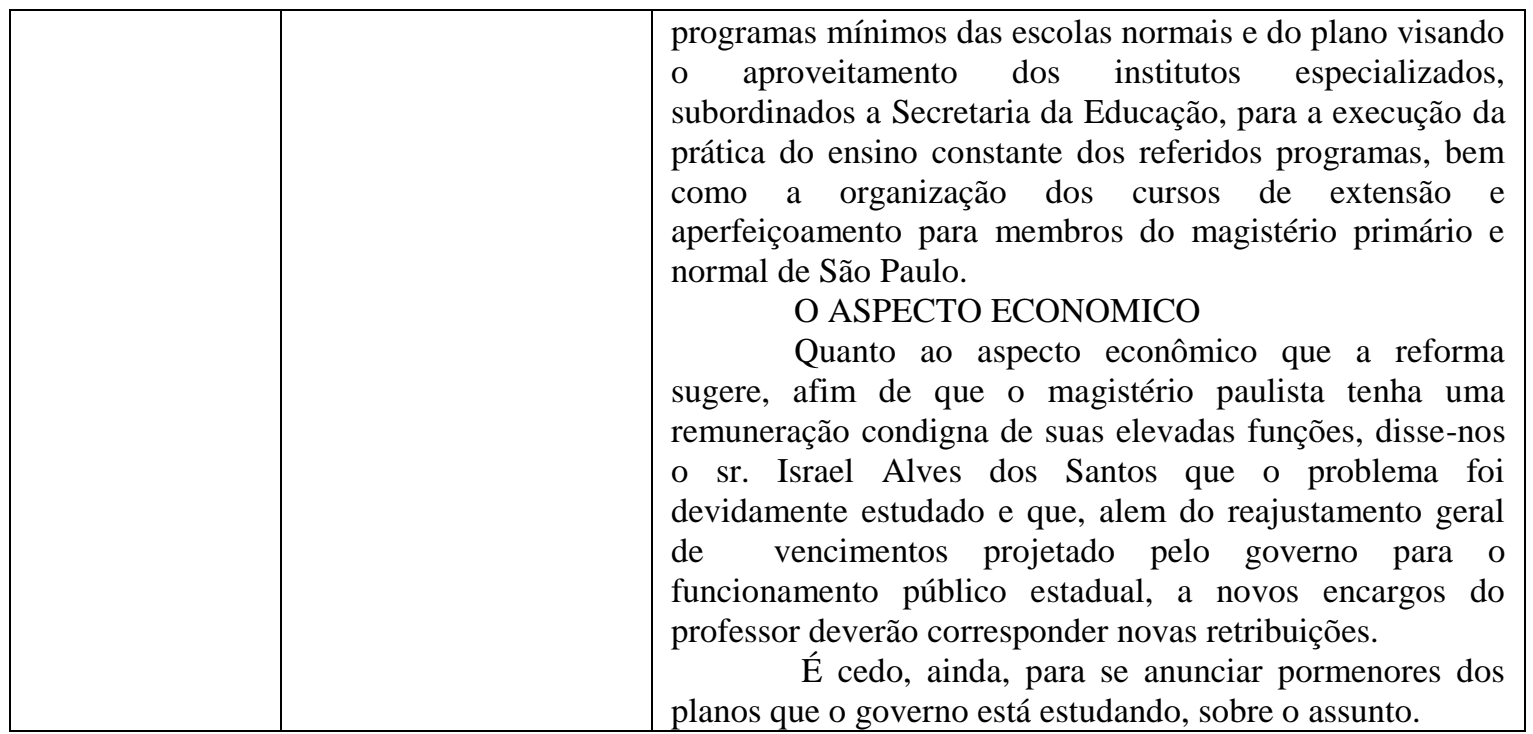

Nesta notícia, ao fim do segundo parágrafo podemos verificar um fator não muito usual dentro do gênero que é a pauta "encomendada" pelo repórter ao seu entrevistado, no caso aqui o diretor do Departamento da Educação, o senhor Israel Alves dos Santos. Temos, portanto, o trecho em que esse fato fica explícito e que se segue: "Atendendo o repórter, o diretor do Departamento de Educação, com sua solicitude habitual, prestou-nos os esclarecimentos desejados."

Podemos dizer que esta notícia destoa das outras, pois parece que foi enviada ao entrevistado com antecedência, dando tempo ao Diretor do Departamento da Educação, o sr. Israel, de se preparar a partir de uma pauta pré-estabelecida pelo jornalista e enviada ao ator social oficial alvo do enunciado. O que nos soa de certo modo um tanto quanto estranho, devido à manipulação que senhor Israel pode ter realizado, já que deve ter tido tempo para pensar nas suas respostas. Passemos, a seguir, a observar tais ocorrências que corroboram para essa afirmação:

Continuando em palestra com o repórter, o sr. Israel Alves dos Santos informou-nos que o projeto de reforma do ensino normal, depois de cuidadosamente estudado pelos participantes das reuniões, não sofreu nenhuma modificação substancial.

O trabalho preliminar já está realizado - continuou o nosso entrevistado _-afim de que se revista de inteiro êxito a projetada reformado ensino normal paulista.

Este texto também tem relação com as estruturas dos anteriores, na medida em que é um relato de uma identidade de cunho oficial, explicando a reforma do ensino, cujo autor social oficial toma a voz da maior parte do texto deixando a voz do jornalista 
em segundo plano; no entanto, a diferença desse texto está no fato dele ser realizado em discurso indireto.

Houve também em certos momentos um lisonjeio da parte do jornalista com relação ao entrevistado, como podemos averiguar no trecho que se segue: "Atendendo o repórter, o diretor do Departamento de Educação, com sua solicitude habitual, prestounos os esclarecimentos desejados."

O termo "solicitude habitual" em conjunto com os termos positivos sobre o projeto - "cuidadosamente estudado", "inteiro êxito" - demonstram não apenas a opinião de Israel Alves dos Santos, diretor do Departamento de Educação, mas também a do jornalista, que se utiliza esse apropria da voz do primeiro para estabelecer e legitimar a sua própria voz.

NOTÍCIA 9 - 06/03/1943

FOI SUPERIOR O NÚMERO DE APROVAÇÕES NOS EXAMES VESTIBULARES ÀS ESCOLAS NORMAIS DO ESTADO

\begin{tabular}{|c|c|c|}
\hline $\begin{array}{l}\text { Tipo de } \\
\text { discurso } \\
\text { empregado }\end{array}$ & $\begin{array}{l}\text { Ator social } \\
\text { atribuído ao } \\
\text { discurso }\end{array}$ & Reprodução do trecho \\
\hline $\begin{array}{l}\text { Discurso } \\
\text { Indireto }\end{array}$ & $\begin{array}{l}\text { Sr. Antenor } \\
\text { Romano } \\
\text { Barreto, } \\
\text { diretor do } \\
\text { Departamento } \\
\text { de Educação }\end{array}$ & $\begin{array}{l}\text { Subtítulo: Em Entrevista que Concedeu às "Folhas", o Diretor } \\
\text { do Departamento de Educação Declarou Não Haver Razão } \\
\text { Para Reduzir a Média de Notas. }\end{array}$ \\
\hline $\begin{array}{l}\text { Discurso } \\
\text { Indireto }\end{array}$ & $\begin{array}{l}\text { Sr. Antenor } \\
\text { Romano } \\
\text { Barreto, } \\
\text { diretor do } \\
\text { Departamento } \\
\text { de Educação }\end{array}$ & $\begin{array}{l}6^{\circ} \S \text { : Foi para esclarecer esse ponto, que procuramos ontem o sr. } \\
\text { Antenor Romano Barreto, diretor geral do Departamento de } \\
\text { Educação. Atendendo-nos em seu gabinete disse-nos s. s. neste ano } \\
\text { tivera o cuidado de convidar para constituírem, as comissões que } \\
\text { deveriam se incumbir da organização dos pontos para os nomes } \\
\text { dos vestibulares de professores do curso fundamental. No ano } \\
\text { passado foram designados os inspetores, para organizar esses } \\
\text { pontos. }\end{array}$ \\
\hline $\begin{array}{l}\text { Discurso } \\
\text { Direto }\end{array}$ & $\begin{array}{l}\text { Sr. Antenor } \\
\text { Romano } \\
\text { Barreto, } \\
\text { diretor do } \\
\text { Departamento } \\
\text { de Educação }\end{array}$ & $\begin{array}{l}7^{\circ} \text { ao } 9^{\circ} \S \text { : "Os pontos - acrescentou - nós os publicamos para que } \\
\text { o publico os conhecesse e nos avaliasse. Publicámos também o } \\
\text { resultado desses exames. Tais resultados dizem bem de como } \\
\text { foram razoáveis os pontos para os referidos exames, pois tivemos } \\
\text { quasi duas dezenas de escolas normais oficiais e livres, cujas } \\
\text { médias de aprovação foram satisfatórias. Tendo-se em vista a } \\
\text { totalidade das escolas obtiveram a totalidade das escolas normais, } \\
\text { percebe-se que as oficiais obtiveram os melhores resultados. Em } \\
\text { algumas, e podemos citar a "Escola Caetano de Campos", muitos } \\
\text { lunos que completam o curso ginasial fundament, } \\
\text { principalmente os melhores, destinam-se aos exames vestibulares á } \\
\text { Faculdade de Filosofia, Ciências e Letras da Universidade de São } \\
\text { Paulo razão também o fato de alunos de outros ginásios buscarem } \\
\text { lugares nessas escolas normais". }\end{array}$ \\
\hline
\end{tabular}




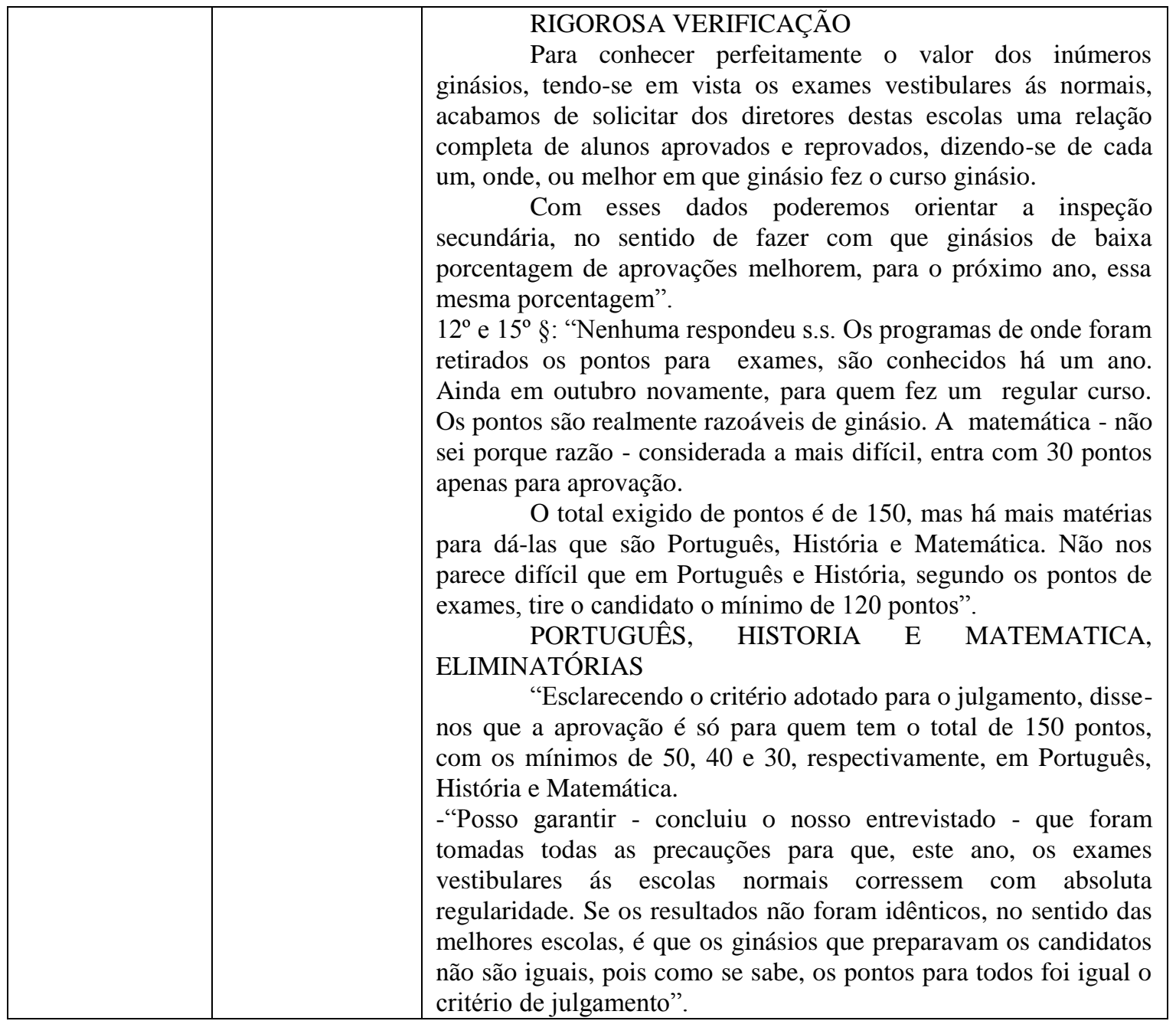

Logo no subtítulo podemos perceber um discurso citado indireto e a autocitação da FSP como "Folhas", veremos a seguir: "Em Entrevista Que Concedeu às "FolhaS", o Diretor do Departamento de Educação Declarou Não Haver Razão Para Reduzir a Média de Notas."

Tal citação da FSP sobre si mesma existe como norma até hoje em seu MRFSP no item Padronização e Estilo em que diz:

Folha - É a forma como a Folha de S. Paulo se refere a ela mesma. Use o termo com moderação, sempre em negrito e começando com letra maiúscula. Em títulos, legendas e nnotas da redação não use negrito. O nome do jornal só deve ser grafado por extenso na transcrição de textos de terceiros, como cartas ou íntegras. Nesse caso mantenha o negrito e a abreviatura $S$. sem espaço antes de Paulo: Folha de S.Paulo. (p. 72).

É interessante notar que na década de 1930 não existia ainda o Manual da Redação da Folha de S. Paulo, mas já existia sua auto-nomeação, talvez não de forma tão padronizada como hoje, no entanto, já havia certa uniformidade do uso. 
Outro ponto importante a ser analisado é que, desde o início da notícia, o jornalista diz que houve uma entrevista, mas ao longo do texto o autor não descreve perguntas e respostas, e sim utiliza-se da voz do Sr. Antenor Romano Barreto, diretor geral do Departamento de Educação, em vários momentos diferentes para compor a sua narrativa. Dessa maneira, o diretor geral aparece como uma voz oficial e única em que o ator social não é contraposto, nem mesmo as medidas ou os critérios pré-estabelecidos por ele perante as notas de classificação para o acesso ao colegial dos cursos normais da época (antigo magistério) são questionados.

Faz-se necessário notar que o diretor do Departamento da Educação se diz democrático e aberto ao público quando diz:

Os pontos_acrescentou_ nós os publicamos para que o publico os
conhecesse e nos avaliasse. Publicámos também o resultado desses exames.
Tais resultados dizem bem de como foram razoáveis os pontos para os
referidos exames, pois tivemos quasi duas dezenas de escolas normais
oficiais e livres, cujas médias de aprovação foram satisfatórias. Tendo-se em
vista a totalidade das escolas obtiveram a totalidade das escolas normais,
percebe-se que as oficiais obtiveram os melhores resultados (...).

Assim, houve até a publicação dos pontos obtidos pelos alunos por meio da avaliação, com o objetivo de que a população aprovasse tal medida imediata adota por ele. Agora poderíamos nos questionar por que não houve a inserção de uma voz de um aluno que não passou na prova e foi prejudicado pela sua nota; ou de um pai de aluno mediano, mas que conseguiu sua vaga; ou então, somente a voz daqueles alunos que entraram com o processo de pedido de redução da média.

O uso dessas vozes geraria conflitos já que haveria uma polifonia além da oficial. No entanto, podemos questionar: Será que ela não ocorre na notícia citada por não ser de praxe no Jornalismo daquela época - ainda mais sob um governo militar -, ou se, para a mentalidade então vigente, daria a impressão de falta de credibilidade deixar um cidadão comum, do povo, ter direito a voz em uma mídia poderosa que reprime a argumentação de vozes que sejam de classes sociais distantes das que detêm o poder?

Sendo assim, na medida em que o jornalista toma para si tão somente a voz oficial como sendo unívoca e sobretudo verdadeira, ele torna a imagem oficial como sendo verdadeira e a transmite através do texto para o leitor e a toda sociedade. 
NOTÍCIA $10-12 / 04 / 1944$

APROVADO PELO CHEFE DO GOVÊRNO O PLANO DE REFORMA DO ENSINO NORMAL EM SÃO PAULO

\begin{tabular}{|c|c|c|}
\hline $\begin{array}{l}\text { Tipo de discurso } \\
\text { empregado }\end{array}$ & $\begin{array}{l}\text { Ator social } \\
\text { atribuído ao } \\
\text { discurso }\end{array}$ & Reprodução do trecho \\
\hline \multirow[t]{2}{*}{ Discurso direto } & $\begin{array}{l}\text { Ministro da } \\
\text { Justiça, } \\
\text { Marcondes } \\
\text { Filho }\end{array}$ & $\begin{array}{l}4^{\circ} \text { ao } 6^{\circ} \S: \text { "Não se trata pròpriamente de uma reforma, } \\
\text { senão de providência destinada a obviar a falta de um ano } \\
\text { no atual primeiro ciclo do Curso Secundário. } \\
\text { Em virtude do Decreto-Lei que veio reformar o } \\
\text { Ensino Secundário, a fase inicial, que era CE cinco anos } \\
\text { (Curso Fundamental) foi reduzida a quatro anos apenas } \\
\text { (Curso Ginasial) e tornou-se insuficiente como preparação } \\
\text { dos candidatos ao Curso Normal". } \\
\text { Acrescenta o relator "o que se tem em mira, no } \\
\text { caso presente, como em alguns outros já aprovados pela C. } \\
\text { E. N. E., é incluir, no Curso Normal, esse ano que a } \\
\text { reforma do Ensino Secundário retirou ao seu primeiro } \\
\text { ciclo". }\end{array}$ \\
\hline & $\begin{array}{l}\text { Sr. } \quad \text { Simão } \\
\text { Lopes }\end{array}$ & $\begin{array}{l}11^{\circ} \S: \text { "O número de aulas ordinárias por semana, será de } \\
12 \text { para todos os professores de escolas normais, exceto os } \\
\text { professores catedráticos da Escola "Caetano de Campos", } \\
\text { que ficam obrigados a } 18 " .\end{array}$ \\
\hline $\begin{array}{l}\text { Discurso indireto } \\
\text { seguido de } \\
\text { discurso direto }\end{array}$ & $\begin{array}{l}\text { Ministro da } \\
\text { Justiça, } \\
\text { Marcondes } \\
\text { Filho }\end{array}$ & $\begin{array}{l}7^{\circ} \S \text { : Para tal fim, é introduzido nesse ano preparatório que } \\
\text { se segue aos quatro anos ginasiais, o estudo das seguintes } \\
\text { disciplinas, como acentua o relator "todas indispensáveis } \\
\text { para que se integre a preparação iniciada no Ginásio" }\end{array}$ \\
\hline Discurso indireto & $\begin{array}{l}\text { Sr. } \quad \text { Simão } \\
\text { Lopes }\end{array}$ & $\begin{array}{l}10^{\circ} \text { §: Frisou o sr. Simões Lopes que é norma do governo } \\
\text { federal tratar, em decreto, em decreto autônomo, da } \\
\text { questão do pessoal. }\end{array}$ \\
\hline
\end{tabular}

Podemos perceber que mais uma vez a voz de autoridade oficial percorre todo o texto, não havendo uma voz que destoe da oficial, assim como todos os outros textos aqui analisados nas décadas de 1930 e 1940. O ator oficial que se insere em todo o discurso é o Ministro da Justiça, Marcondes Filho. No terceiro parágrafo, temos a frase introdutória do discurso direto do Ministro: "Na Comissão de Estudos dos Negócios Estaduais, esclareceu o respectivo relator:"

O verbo "esclarecer" está ligado ao tipo I dos verbos introdutórios de opinião (Marcuschi, 2007), que são os "verbos indicadores de opiniões oficiais e afirmações positivas" e pode-se dizer, além disso, que tal verbo demonstra a superioridade dessas opiniões oficiais detentoras não somente de poder, mas de saber também, pois o verbo "esclarecer" exige um sujeito da ação que predomine sobre os demais e domine o assunto para que tal esclarecimento possa ser eficaz. No início do $6^{\circ}$ parágrafo, podemos também destacar o verbo "acrescentar" que caracteriza "Verbos 
organizadores de um momento argumentativo no conjunto de um discurso" (Marcuschi, 2007), e que também é provido de uma voz oficial e unívoca no texto.

Ao final do texto, podemos perceber que esta notícia se compõe por inteiro em um discurso direto maior que compreende a citação de todo o despacho realizado por Alexandre Marcondes Filho, Ministro da Justiça: "Salvo melhor juízo de v. exa.; parece-me que procedem as observações da C. E. N. E. Aproveito a oportunidade para reiterar a v. exa. os protestos do meu profundo respeito."

Vemos acima a finalização do despacho em primeira pessoa que se refere ao Ministro da Justiça, no entanto temos que levar em conta que as citações diretas e indiretas observadas no quadro e na análise estariam localizadas dentro dessa citação de discurso direto "maior" que foi a citação de um documento, no caso o despacho. Fica evidente que neste texto há uma citação dentro de outra citação, o que nos revela um recorte pequeno, mas muito elucidativo do processo de polifonia. 


\subsection{2 - Características marcantes no corpus das décadas de 1930 e 1940}

Analisamos as décadas de 1930 e 1940 com o intuito de pesquisar as notícias sobre Educação que abrangem o período e descobrir se apresentam uma relação de aceitação das ideias do governo de Getúlio Vargas. O que se pode perceber com as análises dessas 10 notícias, é que o discurso do governo, o discurso oficial e porque não dizer o discurso militar, estão presentes em todas elas.

Não há em nenhuma delas uma contraposição de vozes referentes ao discurso oficial. O jornal dessa época também está voltado para o uso de comunicação oficial, e quanto às notícias relativas à Educação temos, por exemplo, editais de concursos para professor, lista de aprovados em vestibulares, lista de professores aprovados em concursos. Hoje em dia tais informações vêm sendo transmitidas pela internet, dessa forma o jornal perde esse espaço e está sendo substituído por um meio de comunicação mais rápido e instantâneo: a internet.

As notícias são marcadas em sua maioria pelo uso constante do discurso direto, e boa parte desse discurso está ligado a posições oficiais. Os discursos diretos são longos e, muitas vezes, tomam quase que todo o corpo da notícia; portanto, há um apagamento da voz do jornalista que, na maioria das notícias, aparece como um mero introdutor da informação por um discurso proferido por alguma personalidade ou por uma autoridade.

A única voz que não aparece ao longo desses textos é o da massa popular, algum discurso que contrapusesse o discurso oficial. Tudo se passa como se a verdade fosse única e a sociedade totalmente a favor das medidas tomadas pelo governo; no entanto, sabemos pela história que os fatos não eram tão planos e coesos como os relatados pelos jornais. A única notícia no corpus I em que as vozes destoantes aparecem é na Notícia 3 (18/04/1931), em que os estudantes de medicina tomam a voz protestando contra o aumento das taxas dos seus cursos. No entanto, temos que levar em consideração que os estudantes de medicina têm um relativo prestígio social até os dias de hoje e, além disso, essa tomada de voz não foi tão efetiva, pois os estudantes que protestavam e deram declarações nem foram devidamente nomeados, isso pode ter ocorrido por pedido dos próprios estudantes com medo de represálias, mas nesse caso o repórter deveria ter citado o anonimato na notícia. 


\section{2 - Notícias da década de 1970}

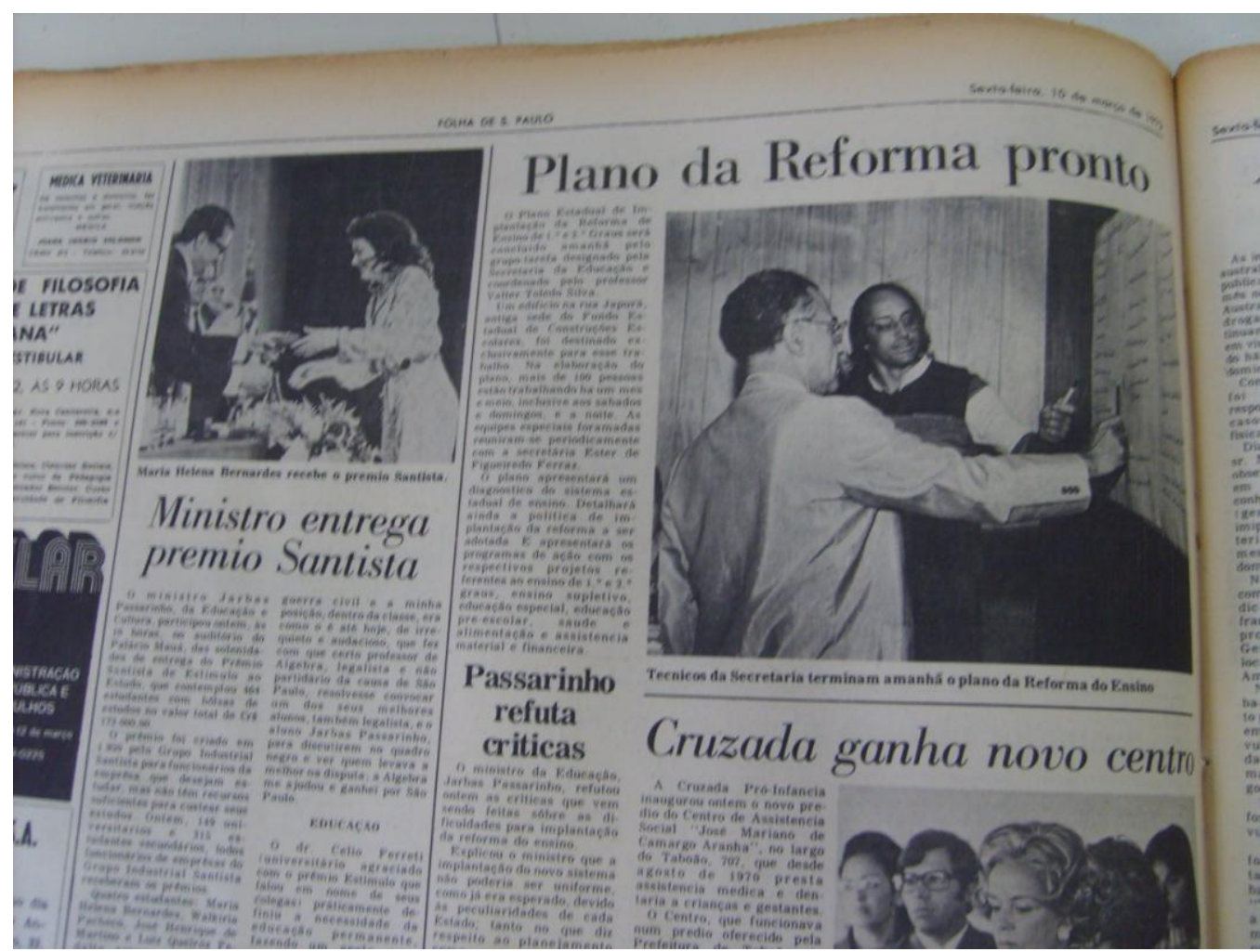

Fig. 6 - Foto de notícia da FSP do dia 10 de março de 1972.

NOTÍCIA 11- 9/03/1972

AULAS EXCEDENTES EM SÃO PAULO

\begin{tabular}{|c|c|c|}
\hline $\begin{array}{l}\text { Tipo de } \\
\text { discurso } \\
\text { empregado }\end{array}$ & $\begin{array}{lr}\text { Ator } & \text { social } \\
\text { atribuído } & \text { ao } \\
\text { discurso } & \end{array}$ & Reprodução do trecho \\
\hline $\begin{array}{l}\text { Discurso } \\
\text { direto }\end{array}$ & $\begin{array}{l}\text { Comunicado da } \\
\text { asessoria técnica } \\
\text { da Secretaria da } \\
\text { Educação }\end{array}$ & $\begin{array}{l}3^{\circ} \S \text { ao } 6^{\circ} \S: \text { "Até a data da publicação do decreto } \mathrm{n}^{\circ} .52 .874 \text {, } \\
\text { de } 8 \text { de fevereiro último, as aulas excedentes ministradas } \\
\text { pelos professores dos estabelecimentos de ensino médio do } \\
\text { Estado era contadas e pagas segundo critério constante do } \\
\text { Decreto } \mathrm{n}^{\circ} \text {. } 51.575 \text {, de } 20 \text { de março de } 1969 \text {, pelo qual, faz } \\
\text { efeito do calculo de pagamento, o mês seria calculado quatro } \\
\text { semanas e meia. } \\
\text { "Acontece que, no governo anterior, precisamente } \\
\text { em julho de 1970, foi propostas por órgãos da Secretaria da } \\
\text { Educação a alteração do referido critério, sob a alegação de } \\
\text { que esse regime infringiria imposições da Lei no. } 10.168 \text {, de } \\
10 \text { de julho de 1968. Logo a seguir, o assunto foi levado ao } \\
\text { exame do Conselho Estadual de Política Salarial, da } \\
\text { Secretaria da Fazenda, o qual, em reunião de } 26 \text { de julho de } \\
1971 \text {, considerando estar "positivado haver uma falha técnica } \\
\text { da legislação, que vem acarretando inúmeras distorções e } \\
\text { problemas de ordem administrativas, só restava aquele órgão } \\
\text { propor a devida correção, o que seria objetivado com a do }\end{array}$ \\
\hline
\end{tabular}




\begin{tabular}{|c|c|c|}
\hline & & $\begin{array}{l}\text { Decreto minutado pelo Departamento Regional da Grande } \\
\text { São Paulo". } \\
\text { "Em virtude dessa resolução, foi baixado o decreto } \\
52.876 \text {, que vem sendo alvos de reiteradas reclamações por } \\
\text { parte dos professores atingidos. } \\
\text { "Alertada sobre o exato alcance da alteração do } \\
\text { critério imposto pelo referido decreto, a profa. Esther } \\
\text { Figueiredo Ferraz tomou a iniciativa de fazer preparar, para } \\
\text { encaminhar ao Conselho de Política Salarial, fundamentada } \\
\text { exposição de motivos no sentido de ser revista aquela } \\
\text { decisão, especialmente por haver verificado, segundo os } \\
\text { cálculos realizados pelos órgãos técnicos da Secretaria da } \\
\text { Educação, que a contagem de aulas excedentes, na forma } \\
\text { proposta ainda anularia, ainda com um pequeno acréscimo, } \\
\text { para os professores do ensino médio, o recente aumento de } \\
\text { vencimentos concedidos pelo Estados aos seus servidores. } \\
\text { Caso não seja considerado viável o reexame da questão pelo } \\
\text { Conselho Estadual de Política Salarial, a Secretaria da } \\
\text { Educação representara ao governo do Estado, propondo seja } \\
\text { encaminhada, com urgência, mensagem a Assembléia } \\
\text { Legislativa, objetivando a correção da mencionada falha } \\
\text { técnica de legislação. }\end{array}$ \\
\hline $\begin{array}{l}\text { Discurso } \\
\text { direto }\end{array}$ & $\begin{array}{l}\text { Secretária } \text { Ester } \\
\text { de Figueiredo } \\
\text { Ferraz }\end{array}$ & $\begin{array}{l}7^{\circ} \text { §: Afirmando que "o governo não desconhece a gravidade } \\
\text { da situação dos que ainda não conseguiram matricula", a } \\
\text { secretaria Ester de Figueiredo Ferraz }\end{array}$ \\
\hline $\begin{array}{l}\text { Discurso } \\
\text { direto }\end{array}$ & $\begin{array}{l}\text { Secretária } \quad \text { da } \\
\text { Educação. }\end{array}$ & $\begin{array}{l}9^{\circ} \S: \text { "Sem a colaboração dos poderes municipais e dos } \\
\text { próprios particulares o Governo do Estado não poderá, de } \\
\text { imediato, aumentar o atendimento do } 2^{\circ} \text { grau. Os municípios } \\
\text { entenderam perfeitamente o problema e já estão assumindo } \\
\text { seu papel nessa tarefa", disse a secretaria da Educação. }\end{array}$ \\
\hline $\begin{array}{l}\text { Discurso } \\
\text { indireto }\end{array}$ & $\begin{array}{l}\text { Secretária } \quad \text { da } \\
\text { educação }\end{array}$ & $\begin{array}{l}10^{\circ} \text { §: Ela informou ainda que grande parte dos recursos } \\
\text { orçamentários da Secretaria, cerca de } \operatorname{Cr} \$ 2 \text { bilhões, foi } \\
\text { aplicada na área do ensino fundamental e na ampliação e } \\
\text { melhoria da infra-estrutura física da rede escolar. }\end{array}$ \\
\hline
\end{tabular}

No início deste texto, já no segundo parágrafo, temos uma frase introdutória do discurso direto que se sucederá nos próximos quatro parágrafos. "Sobre o assunto, a asessoria técnica da Secretaria da Educação distribuiu ontem o seguinte comunicado:"

Surge o comunicado citado fielmente em discurso direto pela Secretaria da Educação, temos aqui novamente o uso de um documento oficial como uso de autoridade por dar maior legitimidade e credibilidade do que a palavra simplesmente falada por um ator oficial. Dessa maneira, o documento oficial é detentor de maior confiabilidade perante a sociedade em meados de 1970.

Pelo quadro exposto anteriormente, podemos perceber o total predomínio do uso de discurso direto e indireto na retranca intitulada "Excedentes do $2^{\circ}$ grau". Nela podemos verificar a presença de dois discursos diretos cuja voz pertence à secretária da Educação, Ester Figueiredo Ferraz, e um discurso indireto da mesma. 
Podemos perceber que, além de não haver muitas inserções de vozes, dentre as inserções existentes nessa notícia da década de 1970, todas são ligadas a uma única voz de autoridade. Não há a configuração de polifonia, ou seja, não foram inseridas vozes e opiniões de professores, alunos, mães de alunos, diretores, supervisores, etc.

Devemos levar em consideração que, nessa época, havia a ditadura militar no Brasil e que durou de 1964 a 1985. Em 1972 o presidente que comandava o nosso país era o general Emílio Garrastazu Médici, havia a censura de imprensa e, por isso, a única voz introduzida em uma notícia de jornal era a voz de uma autoridade oficial competente, no exemplo selecionado a voz de Ester Figueiredo Ferraz, secretária da Educação.

Quanto aos verbos utilizados para introduzir opinião, temos "afirmando" e "informou” que teriam a função, segundo Marcuschi (2007), de indicar posições oficiais o que se confirma a partir do que foi discutido anteriormente.

\section{NOTÍCIA 12- 9/03/1972}

\section{PRECARIEDADE DAS ESCOLAS}

\begin{tabular}{|c|c|c|}
\hline $\begin{array}{l}\text { Tipo de } \\
\text { discurso } \\
\text { empregado }\end{array}$ & $\begin{array}{l}\text { Ator social } \\
\text { atribuído ao } \\
\text { discurso }\end{array}$ & Reprodução do trecho \\
\hline $\begin{array}{l}\text { Discurso } \\
\text { indireto }\end{array}$ & $\begin{array}{l}\text { O governador } \\
\text { de São Paulo } \\
\text { Laudo Natel }\end{array}$ & $\begin{array}{l}6^{\circ} \S \text { : Na escola de Cesário Lange, o governador por questão de } \\
\text { elogiar o diretor Marcio Antonio de Camargo Barros pelo nível } \\
\text { do estabelecimento e registrou suas impressões no livro de } \\
\text { visitas. Ficou satisfeito ao verificar que os prazos para } \\
\text { construção do Colégio Estadual de Porangaba e do Colégio } \\
\text { Integrado - primário e ginásio-de Areiópolis estão sendo } \\
\text { cumpridos na forma estipulada. O colégio de Areiópolis está } \\
\text { sendo construído pela Secretaria da Educação, através do FECE } \\
\text { e seu custo está previsto em } 430 \text { mil cruzeiros. }\end{array}$ \\
\hline $\begin{array}{l}\text { Discurso } \\
\text { direto }\end{array}$ & $\begin{array}{l}\text { O governador } \\
\text { de São Paulo } \\
\text { Laudo Natel }\end{array}$ & $\begin{array}{l}2^{\circ} \S: \text { "Isto, como está, não pode continuar", disse o governador } \\
\text { no interior da escola de Emergência do bairro Jacutinga, que } \\
\text { visitou em companhia do secretário Henri Aidar, chefe da Casa } \\
\text { Civil, e coronel Raul Humaitá, chefe da Casa Militar. } \\
3^{\circ} \S: \text { "Não é possível manter esta situação"- acrescentou o sr } \\
\text {.Laudo Natel. "O Estado permitirá que estas crianças continuem } \\
\text { sem condições adequadas para estudar' } \\
5^{\circ} \text { §: "Fico satisfeto em saber que aqui não há excedentes no } \\
\text { curso ginasial, problema angustiante que, felizmente, já pertence } \\
\text { ao passado" disse o governador Laudo Natel ao visitar depois o } \\
\text { Grupo Escolar Estadual Cesário Lange. }\end{array}$ \\
\hline
\end{tabular}


Como podemos verificar no quadro acima, os discursos citados, sejam eles direto ou indireto são dominados pelo ator social oficial, o governador Laudo Natel que foi duas vezes governador do Estado de São Paulo. A primeira entre 1966 a 1967, como vice-governador, substituiu o então governador Ademar de Barros que foi deposto. A segunda, de 1971 a 1975, foi eleito de maneira indireta, pelo colégio eleitoral. O mais interessante é notar nesta notícia que, diferentemente das décadas de 1930 e 1940, os dicursos diretos são entrecortados por discursos indiretos e vice-versa. Dessa maneira, há certo equilíbrio entre os dois tipos de discurso citado.

NOTÍCIA 13- 13/03/1972

HOJE O PLANO DA REFORMA

\begin{tabular}{|c|c|c|}
\hline $\begin{array}{l}\text { Tipo de } \\
\text { discurso } \\
\text { empregado }\end{array}$ & $\begin{array}{lr}\text { Ator } & \text { social } \\
\text { atribuído } & \text { ao } \\
\text { discurso } & \end{array}$ & Reprodução do trecho \\
\hline \multirow[t]{2}{*}{$\begin{array}{l}\text { Discurso } \\
\text { indireto }\end{array}$} & $\begin{array}{l}\text { Secretaria } \\
\text { estadual de } \\
\text { educação, Esther } \\
\text { de Figueiredo } \\
\text { Ferraz. }\end{array}$ & $\begin{array}{l}1^{\circ} \S: \text { O plano de implantação de reforma de ensino de primeiro } \\
\text { e segundo grau do sistema público e particular de São Paulo } \\
\text { será divulgada hoje as } 11 \text { horas pela secretaria estadual de } \\
\text { educação, professora Esther de Figueiredo Ferraz. }\end{array}$ \\
\hline & $\begin{array}{ll}\text { Plano } & \text { da } \\
\text { Reforma } & \text { da } \\
\text { Educação } & \end{array}$ & $\begin{array}{l}2^{\circ} \S \text { : A reforma de ensino de primeiro (antigo cursos primário } \\
\text { e ginasial) e segundo (antigos cursos, colegial, técnico e } \\
\text { normal) grau será implantada gradativamente. Até } 1975 \\
\text { segundo o plano, a reforma já estará totalmente implantada em } \\
\text { todas as escolas paulistas de primeiro grau, entretanto, a } \\
\text { reforma de segundo grau só estará completamente implantada } \\
\text { em São Paulo, em } 1978 \text {. } \\
7^{\circ} \text { §: O plano tem mais de mil páginas, está dividido em quatro } \\
\text { capítulos distribuídos em três volumes. Começou a ser } \\
\text { elaborado em setembro do ano passado. Os quatro capítulos do } \\
\text { plano são os seguintes: }\end{array}$ \\
\hline
\end{tabular}




\begin{tabular}{|c|c|c|}
\hline $\begin{array}{l}\text { Discurso } \\
\text { direto }\end{array}$ & $\begin{array}{ll}\text { Plano } & \text { da } \\
\text { Reforma } & \text { da } \\
\text { Educação } & \end{array}$ & $\begin{array}{l}8^{\circ} \text { ao } 11^{\circ} \S: 1 \text { - Diagnóstico preliminar da situação geral do } \\
\text { sistema de ensino paulista, sua análise e conclusões que dela } \\
\text { podem se tirar. } \\
\quad 2 \text { - Implantação política de reforma em que se aborda } \\
\text { tudo o que deve ser realizado a curto e médio prazo. A curto } \\
\text { prazo serão implantadas as medidas seguintes: preparação } \\
\text { geral da estrutura física e administrativas e adequação dos } \\
\text { recursos humanos do sistema de ensino paulista. A médio } \\
\text { prazo se desenvolverão as preparações de curto prazo e a } \\
\text { implantação dos novos conteudos pedagógicos. } \\
\quad 3-\text { Ações para efetivação da reforma, em que são } \\
\text { sugeridas normas e recomendaçóes de um programa de ação } \\
\text { para que as medidas do segundo capítulo do plano possam ser } \\
\text { realizadas. } \\
\quad 4 \text { - Este capítulo encerra recomendaçães para } \\
\text { implantação da reforma, principalmente no que toca a recursos } \\
\text { humanos, organizacionais, físicos, financeiros e legais. } \\
\text { Entretanto, somente uma porcentagem mínima dos } 4.000 .000 \\
\text { de estudantes das escolas paulistas de primeiro e segundo } \\
\text { graus serão, este ano, atingidos pela reforma do ensino. A } \\
\text { própria lei } 5692 \text { da reforma de ensino recomenda que sua } \\
\text { implantação seja realizada dentro dos recursos e possibilidades } \\
\text { de cada Estado. }\end{array}$ \\
\hline
\end{tabular}

Podemos verificar na notícia que, assim como algumas notícias da década de 1930 e 1940, não há uso de discurso direto e indireto em que se transmite a voz de um indivíduo ou de um grupo de pessoas. O que temos é uma exposição do que contém o novo plano de ensino. Já foi explicitado que tal estratégia argumentativa serve como um auxílio para que haja uma maior legitimidade do texto perante o leitor do jornal.

Entretanto, podemos anunciar que há uso de discurso citado direto, já que há quatro parágrafos ao longo do texto sobre o plano de ensino. O jornalista fez uso do referido documento como uma estratégia para dar veracidade ao seu texto, já que o plano foi elaborado por autoridades especializadas em educação, endossando o discurso do enunciador.

Esse texto contém a voz instituída de um ator social, ou seja, é uma voz de autoridade. Tal ator social é o governador Laudo Natel que, ao se deparar com as precárias instalações em algumas escolas do interior, pede ao Ministro da Educação medidas para que os problemas de espaço e de instalação sejam solucionados. Para a construção do texto, o enunciador lançou mão de um discurso indireto $\operatorname{logo}$ no $1^{\circ}$ parágrafo: 
Após constatar a precariedade das escolas de emergência instaladas em vários nucleos rurais do município de Bofete durante inspeção de surpresa realizada a obras escolares e rodoviárias do Estado na região, o governador Laudo Natel determinou a Secretaria da Educação que através do Fundo Estadual de Construções Escolares, estude uma solução imediata para o problema.

Podemos perceber uma inversão no enunciado acima, pois primeiro é colocado o fato em si, que era a precariedade das escolas de um município, para depois tornar explícito quem averiguou ou declarou tal fato. Isso pode causar certo estranhamento, na medida em que o nome do governador Laudo Natel não foi enunciado a princípio, a ocorrência de tal fato pode ser explicada pela ausência do lead.

$\mathrm{O}$ jornalista usou mais dois discursos diretos no $2^{\circ}$ e $3^{\circ}$ parágrafos respectivamente:

\footnotetext{
"Isto, como está, não pode continuar", disse o governador no interior da escola de Emergência do bairro Jacutinga.."

"Não é possível manter esta situação"- acrescentou o sr .Laudo Natel. "O Estado permitirá que estas crianças continuem sem condições adequadas para estudar"
}

Essa é mais uma notícia em que prevalece o discurso unilateral e oficial, não sendo de nenhum modo conflitante com qualquer outra voz e, além disso, faz uma apologia à imagem do governador, mostrando-o como: humanitário, trabalhador, fiscalizador, coerente, pró-educação e acima de tudo competente; pois mostra que o seu governo funciona visto que, ao final da notícia, o governador Laudo Natel elogia e se diz surpreso com uma obra em andamento de uma escola Estadual que, segundo ele, está de acordo com os padrões pré-estabelecidos, ao contrário das escolas da prefeitura pelas quais passou e viu precariedade. Assim, presume-se que a escola estadual, que está sob a sua tutela é funcional e apresenta-se dentro dos padrões. 
NOTÍCIA 14- 12/03/1972

\section{A REFORMA TOTAL DO ENSINO ATÉ 1978}

\begin{tabular}{|c|c|c|}
\hline $\begin{array}{l}\text { Tipo de } \\
\text { discurso } \\
\text { empregado }\end{array}$ & $\begin{array}{lr}\text { Ator } & \text { social } \\
\text { atribuído } & \text { ao } \\
\text { discurso } & \end{array}$ & Reprodução do trecho \\
\hline \multirow[t]{2}{*}{$\begin{array}{l}\text { Discurso } \\
\text { indireto }\end{array}$} & $\begin{array}{ll}\text { Coordenador do } \\
\text { Grupo- Tarefa da } \\
\text { Secretaria } \\
\text { Educação- } \\
\text { Valter } \\
\text { Silva }\end{array}$ & $\begin{array}{l}1^{\circ} \S \text { : Em São Paulo, a reforma do ensino de } 1^{\circ} \text { grau que reune } \\
\text { os antigos cursos primário e ginasial, estará totalmente } \\
\text { implantada até } 1975 \text { e a } 2^{\circ} \text { grau, que compreende os antigos } \\
\text { cursos colegial, tecnico e normal, será totalmente implantada } \\
\text { até } 1978 \text {, informou ontem o coordenador do Grupo-Tarefa da } \\
\text { Secretaria de Educação, prof. Valter Toledo Silva. }\end{array}$ \\
\hline & $\begin{array}{ll}\text { Plano } & \text { de } \\
\text { Implantação } & \text { da } \\
\text { Reforma } & \end{array}$ & 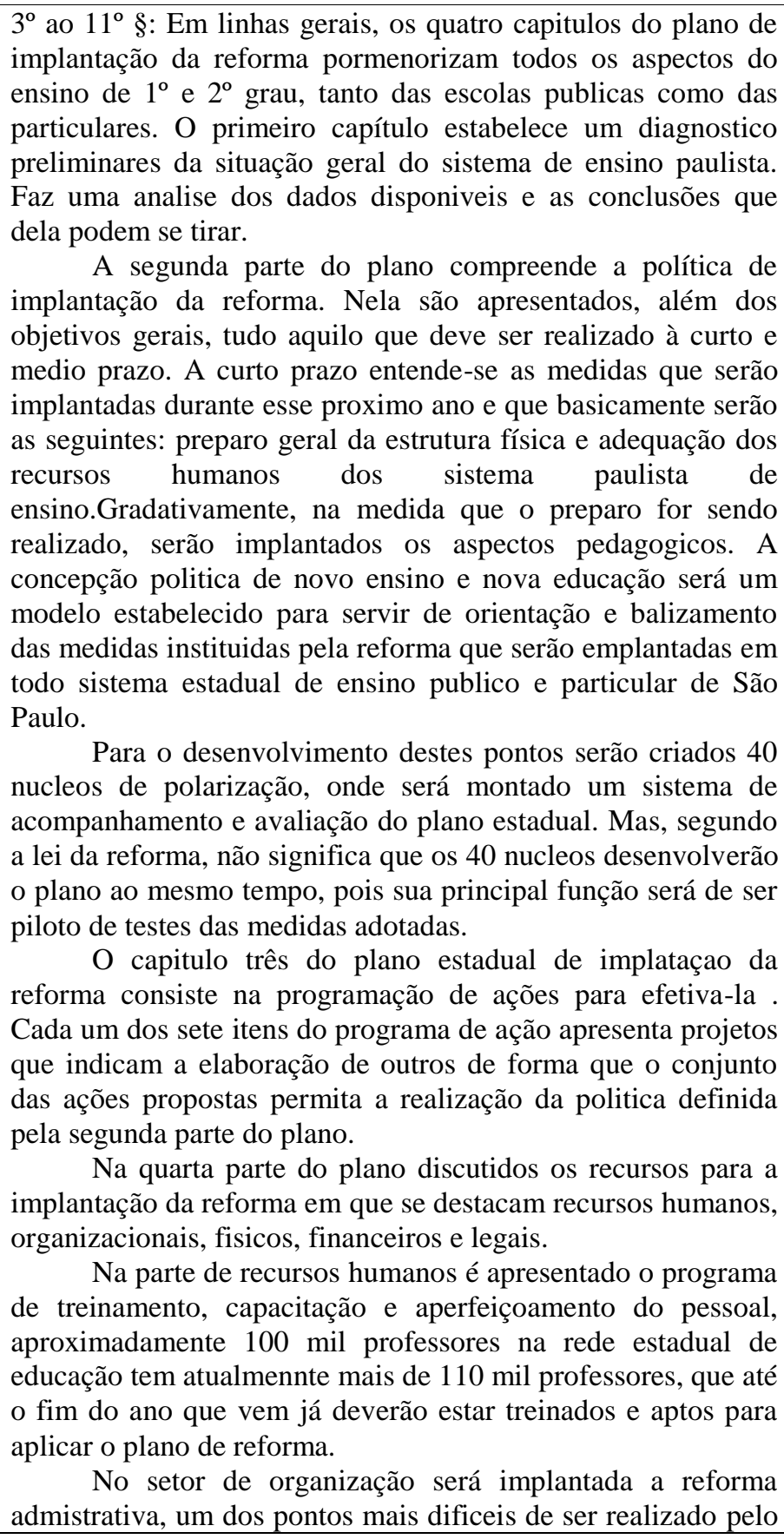 \\
\hline
\end{tabular}




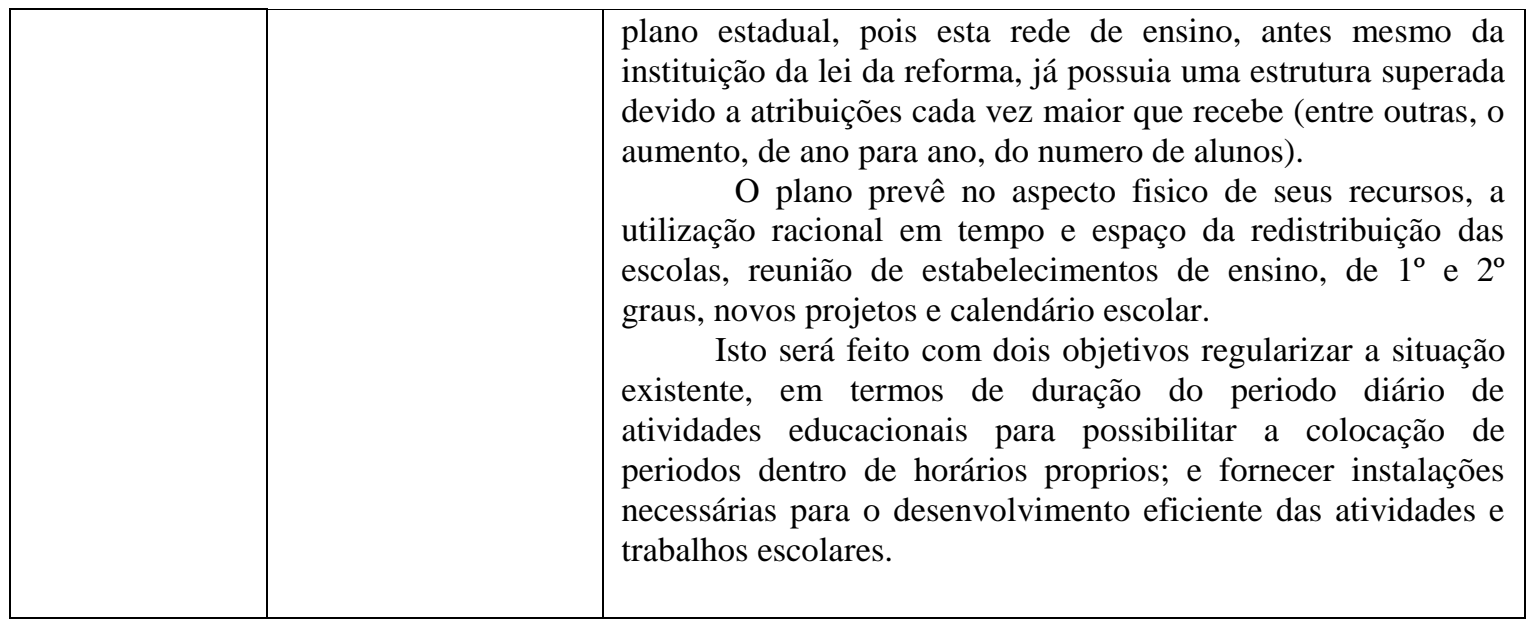

Podemos perceber, por meio do quadro analítico da notícia, que foi nulo o uso de discurso direto neste texto, um dos motivos para que esse fenômeno tenha ocorrido seria porque o jornalista se limitou a dizer como e quando funcionaria a reforma de ensino, resumindo e destacando as partes mais importantes do projeto.

Temos primeiramente o discurso indireto em que o ator social foi o "coordenador do Grupo-Tarefa da Secretaria de Educação, prof. Valter Toledo Silva". Tal ator pertence ao discurso oficial, pois está ligado ao Governo, no entanto, não fica bem explícito, durante a exposição, se todas as informações ao longo do texto foram passadas pelo professor Valter ou somente pela leitura do plano de implantação da reforma.

Mesmo não havendo uma voz marcada por uma pessoa ou um grupo de pessoas, podemos considerar essa notícia polifônica, na medida, em que ela remete a um documento de autoridade que são as leis da reforma, que normalmente não são redigidas individualmente.

O enunciador usa o termo "segundo" no $5^{\circ}$ parágrafo para transmitir o que a lei diz sobre os núcleos de desenvolvimento e o seu funcionamento como veremos no trecho a seguir: "Mas, segundo a lei da reforma, não significa que os 40 nucleos desenvolverão o plano ao mesmo tempo, pois sua principal função será de ser piloto de testes das medidas adotadas". De acordo com Grillo (2001), o termo "segundo" seria um tipo de modalização em que tem uma função de introduzir a fala de outro sujeito. Dessa maneira, há um distanciamento do enunciador mostrando e marcando para seu leitor que 
tal enunciado não lhe pertence e revelando sua posição de imparcialidade e transparência quanto ao assunto em pauta.

É interessante notar que o discurso indireto sobre o Plano de Implantação da Reforma toma quase que todo o corpo do texto e, além disso, em determinados momentos parece haver um processo de humanização deste Plano: ele passa de objeto (papéis com algo escrito) para tomar características consideradas mais humanas, como veremos, por exemplo a seguir:

O plano prevê no aspecto fisico de seus recursos, a utilização racional em tempo e espaço da redistribuição das escolas, reunião de estabelecimentos de ensino, de $1^{\circ}$ e $2^{\circ}$ graus, novos projetos e calendário escolar.

Como seria passível um Plano em sim prever algo, se levarmos em conta o sentido denotativo, isso não teria sentido. No entanto, consideramos que um texto seja precedido de um autor e que este autor sim "prevê" algo. Esse texto se destaca perante os demais pela ausência de discurso direto.

\section{NOTÍCIA 15- 12/04/1972}

\section{FACULDADE NÃO É AUTORIZADA}

\begin{tabular}{|c|c|c|}
\hline $\begin{array}{l}\text { Tipo de } \\
\text { discurso } \\
\text { empregado }\end{array}$ & $\begin{array}{l}\text { Ator social } \\
\text { atribuído ao } \\
\text { discurso }\end{array}$ & Reprodução do trecho \\
\hline $\begin{array}{l}\text { Discurso } \\
\text { indireto }\end{array}$ & $\begin{array}{l}\text { Relator que } \\
\text { participou do } \\
\text { conselho }\end{array}$ & $\begin{array}{l}1^{\circ} \text { §: Segundo o voto do relator, aprovado pelo plenário, existem } \\
\text { na área } 17 \text { Faculdades de Administração, algumas das quais sem } \\
\text { numero suficiente de alunos para o preenchimento de vagas sem } \\
\text { contar -acrescentou- os prejuízos que poderão resultar para } \\
\text { qualidade de ensino. }\end{array}$ \\
\hline $\begin{array}{l}\text { Discurso } \\
\text { direto }\end{array}$ & $\begin{array}{l}\text { Pedidos de } \\
\text { autorização } \\
\text { aprovados }\end{array}$ & $\begin{array}{l}4^{\circ} \text { §: São eles: Faculdade de Filosofia, Ciencias e Letras da } \\
\text { Instituição Universitária Moura de Lacerda, reconhecimento dos } \\
\text { cursos de Geografia, Historia e de Ciencias Sociais, Matemática, } \\
\text { Letras e Pedagogia da Faculdade de Filosofia e Letras; Centro de } \\
\text { Ensino da Alta Paulista (CEALPA), autorização para } \\
\text { funcionamento da Faculdade de Ciencias Contábeis de Lucélia; } \\
\text { Sociedade de Ensino Piratininga, autorização para funcionamento } \\
\text { da Faculdade de Educação; Instituto de Ensino Superior da } \\
\text { Região de Bragantina, de Bragança Paulista, autorização (com } \\
\text { restrições) para o funcionamento da Faculdade de Educação das } \\
\text { Faculdades Integradas Santo Antonio de São Paulo (Capital); } \\
\text { Sociedade Educacional Nova Piratininga, autorização para o } \\
\text { funcionamento da Faculdade de Educação e Ciências; União da } \\
\text { Associação de Ensino de Ribeirão Preto (UNAERP) regimento } \\
\text { da Faculdade de Educação; Centro de Estudos Universitários de } \\
\text { Praia Grande, autorização para o funcionamento da Faculdade de } \\
\text { Educaçãa. }\end{array}$ \\
\hline
\end{tabular}


Nesse texto aqui analisado, podemos verificar pela tabela que houve somente uma ocorrência de discurso indireto que se utilizou do termo "segundo". De acordo com Grillo (2001), é denominado como modalização em segundo discurso, pois trata-se de um elemento modalizador que envia a outro discurso. Esse procedimento do enunciador pode ser uma estratégia de afastamento e do não comprometimento com tais declarações.

Quanto ao ator atribuído ao discurso, é uma problemática porque, embora no texto diga-se que foi um relator, não se nomeia quem foi tal pessoa. Isso nos leva a pensar que o mais importante, no caso dessa notícia, não é o autor do discurso em si, e sim que ele advém de uma fonte oficial segura e pertencente ao conselho que decidiu as aberturas ou não das faculdades apontadas.

Podemos perceber que há um discurso direto no texto quando o enunciador elenca as várias escolas que tiveram aceitação e reconhecimento do Conselho Federal de Educação. É interessante ressaltar que o discurso direto aqui não se apresentou a partir do uso de aspas, mas sim por meio do uso de dois pontos (:). Vemos no trecho que se antecede a listagem de faculdades, a seguir: Sete pedidos de autorização e reconhecimento de escolas paulistanas foram aprovados pelo Conselho em sua última reunião. São eles: (...)

Segundo Maingueneau (2002), as aspas teriam a função de sinalizar “(...) exatamente sobre qual elemento recai a modalização autonímica - no caso, o adjetivo 'horizontal', perfeitamente integrado à sintaxe da frase em que aparece. Contudo, resta ao leitor compreender o valor das aspas que enquadram o adjetivo "horizontal"' (p. 160). Dessa maneira, se por um lado as aspas têm a função de introduzir uma nova voz, mas ao mesmo tempo inseri-la e acoplá-la dentro da frase, como se fazendo pertencente a ela, por outro lado, o dois pontos marcam o fim de uma determinada voz e delimitam a entrada de uma nova voz, quase sempre sendo marcado por uma listagem ou topicalização. 
NOTÍCIA 16- 13/04/1972

MOBRAL NA SEGUNDA ETAPA

\begin{tabular}{|l|lr|l|}
\hline $\begin{array}{l}\text { Tipo de } \\
\text { discurso } \\
\text { empregado }\end{array}$ & $\begin{array}{l}\text { Ator } \\
\text { atribuído } \\
\text { discurso }\end{array}$ & $\begin{array}{r}\text { aocial } \\
\text { ao }\end{array}$ & Reprodução do trecho \\
\hline $\begin{array}{l}\text { Discurso } \\
\text { indireto }\end{array}$ & $\begin{array}{l}\text { A direção do } \\
\text { MOBRAL }\end{array}$ & $\begin{array}{l}1^{\circ} \text { A direção do MOBRAL anunciou ontem durante a sessão } \\
\text { plenária do II Encontro Nacional que se realiza no Hotel das } \\
\text { Paineiras, no Rio de Janeiro, o lançamento em agosto da } \\
\text { segunda etapa dos cursos de Educação integrada em todo o } \\
\text { País nos municipios que já vêm promovendo em carater } \\
\text { experimental a primeira fase. }\end{array}$ \\
\hline $\begin{array}{l}\text { Discurso } \\
\text { direto }\end{array}$ & $\begin{array}{l}\text { Coordenador } \\
\text { entidade } \\
\text { Estado } \\
\text { Tomazzi. }\end{array}$ & $\begin{array}{l}4^{\circ} \text { \&u "O trabalho do MOBRAL em São Paulo estão se } \\
\text { desenvolvendo em ritmo acelerado. Podendo-se prever para } \\
\text { dentro de seis anos no máximo a erradicação do } \\
\text { analfabetismo em todo o Estado", revelou o coordenador de } \\
\text { entidade no Estado Luiz Tomazzi. }\end{array}$ \\
\hline
\end{tabular}

No $1^{\circ}$ parágrafo há a ocorrência de um discurso indireto e a voz de autoridade corresponde a um grupo de pessoas A direção do MOBRAL (Movimento Brasileiro de Alfabetização). Se levarmos em consideração que a direção do MOBRAL é composta por educadores que ocupam cargos da mais alta patente, verificamos que essa direção possui uma voz conceituada, sendo assim considerada detentora de autoridade. O verbo "anunciou" utilizado no referido excerto é, segundo Marcuschi (2007), um "verbo indicador de posição oficial e afirmações positivas". Atentamo-nos ao trecho que segue:

A direção do MOBRAL anunciou ontem durante a sessão plenária do II Encontro Nacional que se realiza no Hotel das Paineiras, no Rio de Janeiro, o lançamento em agosto da segunda etapa dos cursos de Educação integrada em todo o País nos municipios que já vêm promovendo em carater experimental a primeira fase.

É possível relacionar que a diretoria do MOBRAL está atrelada ao plano do governo para erradicar o analfabetismo no Brasil, portanto está diretamente ligada à posição oficial. E o verbo "anunciou" também está correlacionado a algo positivo que ocorrerá, ou seja, que haverá a efetivação dos cursos em municípios que já estavam em fase experimental.

Na primeira retranca denominada "São Paulo", temos logo no inicio do $1^{\circ}$ parágrafo o discurso direto do coordenador do MOBRAL em São Paulo, Luiz Tomazzi. A inserção segue: 
“O trabalho do MOBRAL em São Paulo estã se desenvolvendo em ritmo acelerado. Podendo-se prever para dentro de seis anos no máximo a erradicação do analfabetismo em todo o Estado", revelou o coordenador de entidade no Estado Luiz Tomazzi.

Não houve a ocorrência de um verbo introdutório para marcar a opinião, mas a frase é usada como se fosse uma chamada, um subtítulo e, de certa forma, uma propaganda que marca o avanço de São Paulo. Podemos considerar que nesse discurso direto está embutida a imagem que se tem e que vigora até hoje: a de que São Paulo é um estado moderno e avançado perante os demais estados brasileiros.

NOTÍCIA 17- 25/04/1977

ATÉ FIM DO ANO MEC NÃO PERMITE NOVOS CURSOS

\begin{tabular}{|c|c|c|}
\hline $\begin{array}{l}\text { Tipo de } \\
\text { discurso } \\
\text { empregado }\end{array}$ & $\begin{array}{l}\text { Ator social } \\
\text { atribuído ao } \\
\text { discurso }\end{array}$ & Reprodução do trecho \\
\hline \multirow[t]{2}{*}{$\begin{array}{l}\text { Discurso } \\
\text { indireto }\end{array}$} & $\begin{array}{l}\text { Professor } \\
\text { Sucupira }\end{array}$ & $\begin{array}{l}1^{\circ} \text { e } 2^{\circ} \xi \text { : O conselho Federal de Educação vai discutir sua reunião } \\
\text { plenária mensal que começa } 2^{\circ} \text { feira, novos critérios de autorização } \\
\text { para o funcionamento de novos cursos superiores. A informação } \\
\text { foi dada ontem pelo professor Newton Sucupira em palestra feita } \\
\text { na Universidade Federal do Rio de Janeiro. } \\
\text { Até o final do ano, o Ministério da Educação não vai autorizar o } \\
\text { funcionamento de novos cursos - afirmou o professor Sucupira, } \\
\text { depois de fazer uma abordagem sobre o ensino brasileiro em que } \\
\text { procura negar uma queda de qualidade em termos globais na } \\
\text { Educação do País. } \\
4^{\circ} \text { §: As escolas terão que justificar a criação dos novos cursos e o } \\
\text { MEC irá confrontá-las com critérios próprios, levando em conta. } \\
\text { Inclusive o problema de distritos educacionais da região e do } \\
\text { próprio País. Entretanto, ainda que o mercado de trabalho esteja } \\
\text { saturado, o curso poderá ser autorizado, se contribuir para o } \\
\text { aperfeiçoamento de padrão, dentro de um critério de excelência- } \\
\text { assegurou o professor Sucupira, presidente da comissão que estuda } \\
\text { o assunto } \\
6^{\circ} \text { §: A pós-graduação não está incluida nestas normas e o } \\
\text { reconhecimento de cursos já existentes é considerado prioritário } \\
\text { pelo Conselho, disse o professor Sucupira, acrescentando que o } \\
\text { problema das faculdades ainda não reconhecidas é culpa das } \\
\text { próprias escolas que formam turmas e não entram com pedido de } \\
\text { reconhecimento. }\end{array}$ \\
\hline & $\begin{array}{l}\text { Conselho de } \\
\text { Educação }\end{array}$ & $\begin{array}{l}6^{\circ} \S \text { Segundo o conselho, as faculdades frequentemente } \\
\text { negligenciam e não atendem com presteza ás exigências para o } \\
\text { reconhecimento. Por isso, o MEC baixou normas proibindo } \\
\text { vestibulares nas faculdades que até o segundo ano de } \\
\text { funcionamento não entrem com processo de pedido de } \\
\text { reconhecimento. }\end{array}$ \\
\hline
\end{tabular}




\begin{tabular}{|c|c|c|}
\hline & $\begin{array}{l}\text { Professor } \\
\text { Newton } \\
\text { Sucupira }\end{array}$ & $\begin{array}{l}7^{\circ} \text { e } 8^{\circ} \text { §: Ainda sobre a proliferação de cursos, o prof. Newton } \\
\text { Sucupira afirmou que a expansão foi detida desde o segundo } \\
\text { semestre do ano passado, quando o MEC tinha mais de } 100 \\
\text { pedidos que não foram atendidos, enquanto em } 1972 \text { houve } 320 \\
\text { autorizações. } \\
\text { QUALIDADES } \\
\text { Falando sobre o ensino brasileiro, o prof. Newton Sucupira } \\
\text { disse, durante os debates, ser falso o conceito de queda de } \\
\text { qualidade, havendo mesmo no seu entender, um aumento gradual } \\
\text { de rendimento. }\end{array}$ \\
\hline & & $\begin{array}{l}11^{\circ} \text { §: O prof. Newton Sucupira declarou-se favorável a uma } \\
\text { elitização cada vez maior nos cursos de pós-graduação, tornando } \\
\text { rigoroso o acesso a eles. E justificou sua posição através de } \\
\text { citações de autores russos. }\end{array}$ \\
\hline $\begin{array}{l}\text { Discurso } \\
\text { direto }\end{array}$ & $\begin{array}{l}\text { Professor } \\
\text { Newton } \\
\text { Sucupira }\end{array}$ & $\begin{array}{l}9^{\circ} \text { e } 10^{\circ} \S: \text { "Hà "ilhas" de péssima qualidade, mas no conjunto não } \\
\text { houve quebra de qualidade. Num balanço global, o ensino superior } \\
\text { não está decadente, se considerarmos os padrões de antigamente". } \\
\text { E prosseguiu: } \\
\text { "Não submergimos num mar de má qualidade, mas temos } \\
\text { muito que fazer principalmente em relação ao acesso às escolas } \\
\text { onde há desigualdade entre a maioria e as famílias abastadas". }\end{array}$ \\
\hline
\end{tabular}

Podemos perceber a voz de autoridade do professor Newton Sucupira que perpassa por todo o texto. Ele foi o precursor e responsável sobre a reforma universitária no final da década de 1960 e ocupou o cargo de presidente da Câmara do Ensino Superior por dez anos.

Tal ator social aparece, predominantemente, no discurso indireto, no entanto, ao final do texto sua voz ganha maior importância e é transcrita em discurso direto. Podemos ver a evolução da imagem do professor Sucupira a partir de suas citações, que são entrecortadas apenas pela voz do Conselho de Educação do qual ele faz parte e tem um cargo de grande importância.

Segundo o conselho, as faculdades frequentemente negligenciam e não atendem com presteza ás exigências para o reconhecimento. Por isso, o MEC baixou normas proibindo vestibulares nas faculdades que até o segundo ano de funcionamento não entrem com processo de pedido de reconhecimento.

O discurso direto aparece ao final do texto, nos últimos parágrafos, e isso pode corroborar para a tese de quão importante a voz de Newton Sucupira era para a sociedade da época.

"Hà "ilhas" de péssima qualidade, mas no conjunto não houve quebra de qualidade. Num balanço global, o ensino superior não está 
decadente, se considerarmos os padrões de antigamente". E prosseguiu

"Não submergimos num mar de má qualidade, mas temos muito que fazer principalmente em relação ao acesso às escolas onde há desigualdade entre a maioria e as famílias abastadas".

NOTÍCIA 18- 29/04/1977

477 E ENSINO GRATUITO VÃO FICAR, SEGUNDO O MINISTRO

\begin{tabular}{|c|c|c|}
\hline $\begin{array}{ll}\text { Tipo } & \text { de } \\
\text { discurso } & \\
\text { empregado } & \end{array}$ & $\begin{array}{l}\text { Ator social } \\
\text { atribuído ao } \\
\text { discurso }\end{array}$ & Reprodução do trecho \\
\hline Discurso direto & $\begin{array}{lr}\text { Ministro } & \text { Nei } \\
\text { Braga } & \text { da } \\
\text { Educação } & \end{array}$ & $\begin{array}{l}11^{\circ} \S: \text { "O Governo Geisel não vai instituir o ensino pago nas } \\
\text { escolas publica do País', por entender que não será resolvido, } \\
\text { dessa maneira, o problema da falta de recursos para o setor } \\
\text { educacional. Da mesma forma, não pretende reestruturar a atual } \\
\text { legislação estudantil, que ainda não foi suficientemente testada } \\
\text { para que possa ser considerada insatisfatória" }\end{array}$ \\
\hline \multirow[t]{3}{*}{$\begin{array}{l}\text { Discurso } \\
\text { indireto }\end{array}$} & $\begin{array}{lr}\text { Ministro } & \text { Nei } \\
\text { Braga } & \text { da } \\
\text { Educação } & \end{array}$ & $\begin{array}{l}2^{\circ} \text { §: Essas informações foram dadas ontem pelo ministro Nei } \\
\text { Braga da Educação, durante depoimento de quatro horas que } \\
\text { prestou perante a Comissão de Educação e Cultura do Senado } \\
\text { Federal. } \\
6^{\circ} \text { §: Durante seu pronunciamento, o ministro Nei Braga } \\
\text { procurou mostrar-se preocupado com a função humanistica da } \\
\text { Educação, afirmando que é fundamental aliar á função de } \\
\text { formação de recursos humanos à função humanística da } \\
\text { Educação. }\end{array}$ \\
\hline & $\begin{array}{l}\text { O senador } \\
\text { Itamar } \\
\text { Montoro } \\
\text { (MDB-MG) } \\
\text { e } \\
\text { Nei Braga }\end{array}$ & $\begin{array}{l}3^{\circ} \S: \text { O senador Itamar Montoro (MDB-MG) indagou ao a } \\
\text { ministro da possibilidade de ser incluida entre as disciplinas do } \\
\text { curso superiora referente aos direitos fundamentais do homem. } \\
\text { Nei Braga respondeu que solicitará a seus assessores que analise } \\
\text { a sugestão do parlamentar, mas que inicialmente, acredita que } \\
\text { tal matéria possa ser ministrada na disciplina de Estudo de } \\
\text { Problemas Brasileiros. }\end{array}$ \\
\hline & $\begin{array}{l}\text { Ministro da } \\
\text { educação Nei } \\
\text { Braga }\end{array}$ & $\begin{array}{l}8^{\circ} \text { §: Embora ressaltando que não estava defendendo a tese do } \\
\text { pluripartidarismo, o ministro Nei Braga fez uma sugestão aos } \\
\text { parlamentares no sentido de que cada partido possua } \\
\text { departamentos especializados em determinado problema ou } \\
\text { setor nacional. } \\
12^{\circ} \text { ao } 15^{\circ} \S \text { : Falou sobre todos os setores do MEC, inclusive o } \\
\text { de esporte e cultura, salientando, entre todas as atividades, o } \\
\text { programa de Crédito Educativo, implantado no ano passado. } \\
\text { Segundo suas informações, o número de alunos beneficiados } \\
\text { com tal financiamento passou de } 150 \text { mil, em 1976, para } 280 \\
\text { mil, neste ano. } \\
\text { Ressaltou também a verba orçamentária da Empresa } \\
\text { Brasileira de Filmes (Embrafilmes), que receberá este ano } 100 \\
\text { milhões de cruzeiros, além dos } 80 \text { milhões recebidos em } \\
\text { setembro de } 1976 \text {. } \\
\text { Na área do Mobral, informou que o MEC está } \\
\text { procedendo a um estudo sobre os indices de regressão escolar, a } \\
\text { fim de conhecer quais as causas reais do fenômeno e descobrir } \\
\text { novas metodologias e processos que possam evitá-lo. } \\
\text { Sobre o setor desportivo, disse que o Departamento de }\end{array}$ \\
\hline
\end{tabular}




\begin{tabular}{|c|c|c|}
\hline & & $\begin{array}{l}\text { Educação Física e Desportos está estudando a desvinculação da } \\
\text { CBD das áreas de natação e atletismo, para as quais serão } \\
\text { criadas duas Confederaçôes específicas. }\end{array}$ \\
\hline $\begin{array}{l}\text { Discurso } \\
\text { indireto } \\
\text { seguido de } \\
\text { Discurso direto }\end{array}$ & $\begin{array}{l}\text { O senador } \\
\text { Itamar } \\
\text { Montoro } \\
\text { (MDB-MG) } \\
\text { e } \\
\text { Nei Braga }\end{array}$ & $\begin{array}{l}4^{\circ} \text { §: Outra pergunta formulada pelo senador mineiro foi com } \\
\text { relação à legislação estudantil. Ele quis saber se o MEC não tem } \\
\text { intenção de reestudá-la, obtendo a seguinte resposta: "Não, pois } \\
\text { a atual legislação não doi ainda suficientemente testada para que } \\
\text { possamos considerá-la insatisfatória". } \\
5^{\circ} \text { §: Sobre a instituição do ensino pago no Brasil, tese defendida } \\
\text { quase que unanimente pelos senadores, o ministro disse ser } \\
\text { contra a medida e que durante sua gestão ela não será adotada. } \\
\text { Respondendo diretamente ao senador Evilásio Vieira (MDB- } \\
\text { SC), afirmou que "respeita tal ponto de vista, (favorável ao } \\
\text { ensino pago), mas não acredita ser essa a solução para o } \\
\text { problema da falta de recursos financeiros no setor educacional", } \\
\text { conforme insinuou o parlamentar. } \\
7^{\circ} \S \text { : Disse, ainda o titular da Educação que é condenável a } \\
\text { capacitação profissional a quem não tiver compreendido, antes } \\
\text { de tudo, "a consciência de seu papel na sociedade, de sua } \\
\text { posição na história, de seus deveres e de seu relacionamento } \\
\text { humano". } \\
16^{\circ} \text { §: Ao concluir seu pronunciamento o ministro Nei Braga } \\
\text { agradeceu aos senadores o convite para que participasse da } \\
\text { Comissão de Educação daquela Casa, afirmando que "aqui me } \\
\text { senti em casa e todos os meus assessores também puderam ficar } \\
\text { à vontade". }\end{array}$ \\
\hline Discurso direto & $\begin{array}{l}\text { Ministro da } \\
\text { educação Nei } \\
\text { Braga }\end{array}$ & $\begin{array}{l}9^{\circ} \S \text { : Acrescentou que "um partido concentraria sua atenção nos } \\
\text { problemas educacionais, em outro nas questões ligadas à } \\
\text { agricultura, um terceiro nos setores econômicos e assim por } \\
\text { diante. Mas como não há pluripartidarismo isso pode ser feito } \\
\text { através das duas agremiações existentes". } \\
17^{\circ} \S \text { : "Nosso relacionamento deverá multiplicar-se, franco e } \\
\text { aberto, e permanente a cada dia. Estou e estarei sempre às } \\
\text { ordens e atento às proposições e contribuições oportunas que } \\
\text { houver por bem apresentar ou solicitar dessa casa. A todos } \\
\text { expresso meu forte empenho em manter um vivido e proficuo } \\
\text { intercâmbio que nos coloque, sempre, em sintonia com os } \\
\text { grandes problemas da educação nacional concluiu o ministro. }\end{array}$ \\
\hline
\end{tabular}

Podemos verificar nesse texto uma grande inserção de vozes sejam elas diretas ou indiretas, ou indiretas seguidas de diretas, o fato é que essa notícia apresentou maior uso de discurso citado que as demais anteriores aqui analisadas. Logo no início do texto, temos um discurso citado direto, mas nele não é revelado seu ator social, a nomeação desse ator só irá aparecer no segundo parágrafo que seria o Ministro da Educação, o senhor Nei Braga.

No terceiro parágrafo, no começo da retranca intitulada "Direitos Humanos" é interessante notar que em um mesmo parágrafo há um discurso indireto compostos por 
dois atores sociais distintos. Dessa maneira, o jornalista se presta ao papel apenas de relatar o que foi perguntado ao Ministro da Educação pelo Senador Itamar Montoro e o que Nei Braga respondeu. Isso vai ocorrer no terceiro e no quarto parágrafos sucessivamente. Já no quinto parágrafo aparece outro ator social, o senador Evilásio Vieira, no seguinte excerto:

Respondendo diretamente ao senador Evilásio Vieira (MDB-SC), afirmou que "respeita tal ponto de vista, (favorável ao ensino pago), mas não acredita ser essa a solução para o problema da falta de recursos financeiros no setor educacional", conforme insinuou o parlamentar.

Podemos verificar dois fatores importantes neste enunciado: primeiro que o jornalista aponta uma resposta direta para o senador, no entanto, não elucida que pergunta foi essa, ele omite tal questão. O segundo ponto diz: "conforme insinuou o parlamentar" o verbo "insinuar" é usado, segundo a classificação dos verbos e suas funções - estabelecidas por Marcuschi (2007) - podemos classificar como um "Verbo indicador de emocionalidade circuntancial", o que pode nos levar à conclusão de uma imparcialidade do jornalista, diante das discussões calorosas entre Ministro da Educação e senadores.

Nas demais retrancas que são: "Política", "Dados Quantitativos" e “Agradecimentos”, não houve maiores conflitos, e a única voz que aparece ao longo do texto é a do Ministro da Educação. Portanto, podemos averiguar que houve um conflito de vozes somente na retranca intitulada "Direitos Humanos" em que senadores e o Ministro da Educação divergiram com relação à cobrança ou não do ensino público. Isso pode nos levar a outra conclusão pelo que verificamos na análise dos demais textos. Esse conflito de vozes só foi passível de ser enunciado no jornal da década de 1970 porque se tratava de que todos os atores sociais presentes no texto eram figuras oficiais e pertencentes ao governo e possuiam de cargos de alta patente, mesmo tendo opiniões divergentes. 


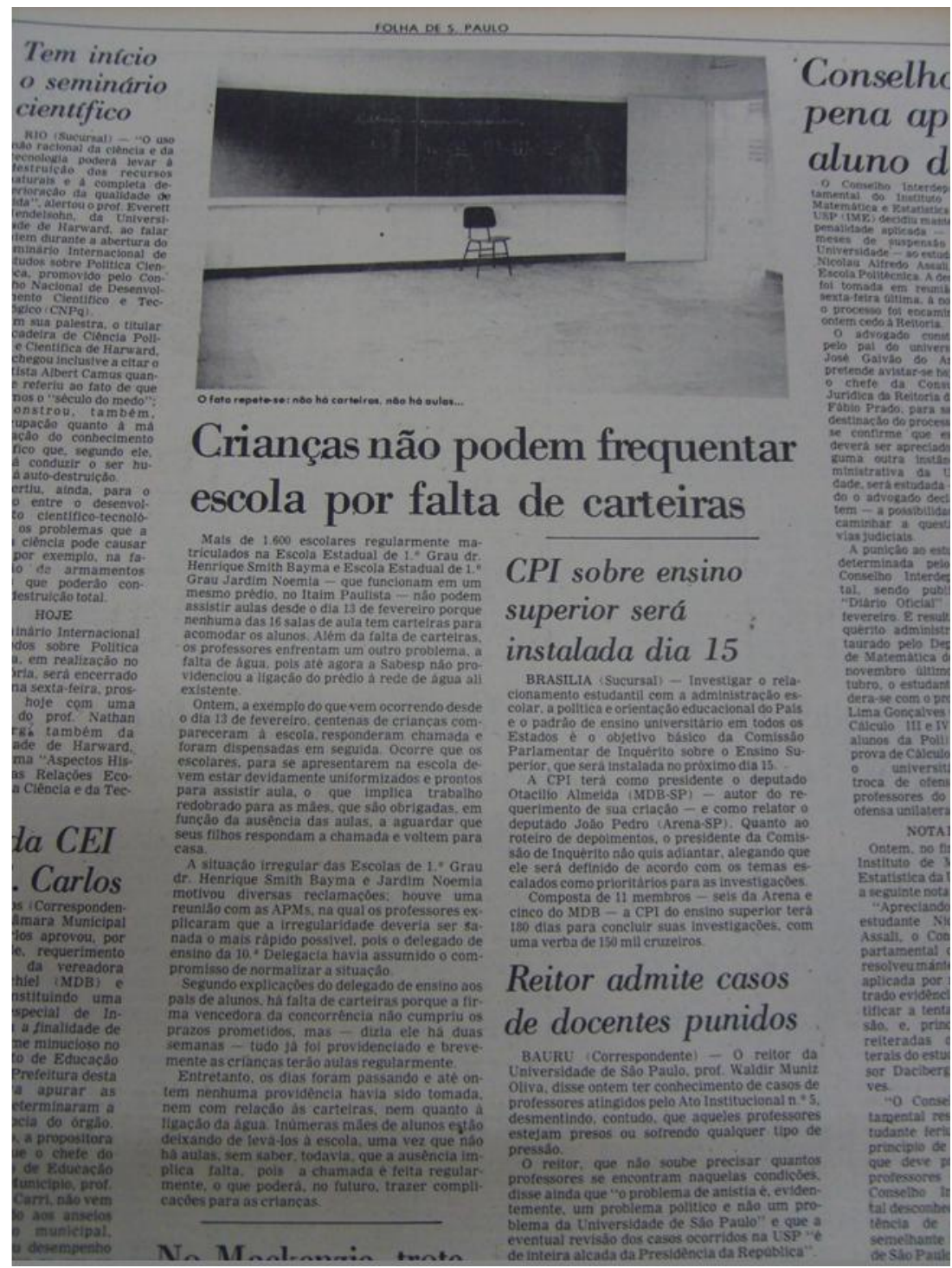

Fig. 7- Foto de notícia da FSP do dia 7 de março de 1978

NOTÍCIA 19- 07/03/1978

CRIANÇAS NÃO PODEM FREQUENTAR ESCOLA POR FALTA DE CARTEIRAS

\begin{tabular}{|c|c|c|}
\hline $\begin{array}{l}\text { Tipo de } \\
\text { discurso } \\
\text { empregado }\end{array}$ & $\begin{array}{lr}\text { Ator } & \text { social } \\
\text { atribuído } & \text { ao } \\
\text { discurso } & \end{array}$ & Reprodução do trecho \\
\hline $\begin{array}{l}\text { Discurso } \\
\text { indireto }\end{array}$ & $\begin{array}{l}\text { Professores } r \text { das } \\
\text { escolas de } 1^{\circ} \text { Grau } \\
\text { dr. Henrique Smith } \\
\text { Bayma e Jardim } \\
\text { Noêmia }\end{array}$ & $\begin{array}{l}3^{\circ} \S \text { : A situação irregular das Escolas de } 1^{\circ} \text { Grau dr. } \\
\text { Henrique Smith Bayma e Jardim Noêmia motivou } \\
\text { diversas reclamações; houve uma reunião com as APMs, } \\
\text { na qual os professores explicaram que a irregularidade } \\
\text { deverá ser sanada o mais rápido possível, pois o delegado } \\
\text { de ensino de } 10^{a} \text { Delegacia havia assumido o compromisso } \\
\text { de normalizar a situação }\end{array}$ \\
\hline
\end{tabular}




\begin{tabular}{|l|l|l|}
\hline $\begin{array}{l}\text { Discurso } \\
\text { indireto }\end{array}$ & $\begin{array}{l}4^{\circ} \text { §: Segundo explicações do delegado de ensino aos pais } \\
\text { de alunos, há falta de carteiras porque a firma vencedora } \\
\text { da concorrência não cumpriu os prazos prometidos, mas - } \\
\text { dizia ele há duas semanas - tudo já foi providenciando e } \\
\text { brevemente as crianças terão aulas regularmente. }\end{array}$ \\
\hline
\end{tabular}

Podemos notar dois discursos indiretos e a ausência de discurso direto nesta notícia. Na década de 1970 os atores sociais elencados foram: Delegado de ensino e Professores das escolas em questão. No entanto, não houve a inserção de voz de uma mãe ou de um aluno prejudicado pela falta de água e carteira nas salas de aula. Foram até elencadas as reclamações das mães e dos alunos mas, suas identidades foram omitidas e suas vozes diluídas como veremos nos excertos a seguir $\left(2^{\circ}\right.$ e $5^{\circ}$ parágrafo respectivamente):

Ontem, a exemplo do que vem ocorrendo desde o dia 13 de fevereiro, centenas de crianças compareceram à escola, respondem chamada $\mathrm{e}$ foram dispensadas em seguida. Ocorre que os escolares, para se apresentarem na escola devem estar devidamente uniformizados e prontos para assistir aula, o que implica trabalho redobrado para as mães, que são obrigados, em função da ausência das aulas, a aguardar que seus filhos respondam a chamada e voltem para casa.

Entretanto, os dias foram passando e até ontem nenhuma providência havia sido tomada nem com relação ás carteira, nem quanto a ligação da água. Inúmeras mães de alunos estão deixando de levá-los á escola, uma vez que não há aula, se saber, todavia, ausência implica falta, pois a chamada é feita regularmente, o que poderá, no futuro, trazer complicações para as crianças.

Dessa forma, o enunciador, no caso aqui o jornalista, toma a voz para si e apenas faz um relato da situação, não deixando margem para que mães de aluno ou até mesmo os alunos tenham voz para protestar dentro de seu texto. 
NOTÍCIA 20- 14/03/1978

\section{CRITICADO O ENSINO DE $2^{\circ}$ GRAU NO MEC}

\begin{tabular}{|c|c|c|}
\hline $\begin{array}{l}\text { Tipo de } \\
\text { discurso } \\
\text { empregado }\end{array}$ & $\begin{array}{lr}\text { Ator } & \text { social } \\
\text { atribuído } & \text { ao } \\
\text { discurso } & \end{array}$ & Reprodução do trecho \\
\hline $\begin{array}{l}\text { Discurso } \\
\text { indireto }\end{array}$ & $\begin{array}{lr}\text { Diretor } & \text { do } \\
\text { Departamento } & \text { de } \\
\text { Ensino } & \text { Médio } \\
\text { (DEM) do } & \text { MEC, } \\
\text { coronel Torquato } \\
\text { Jardim }\end{array}$ & 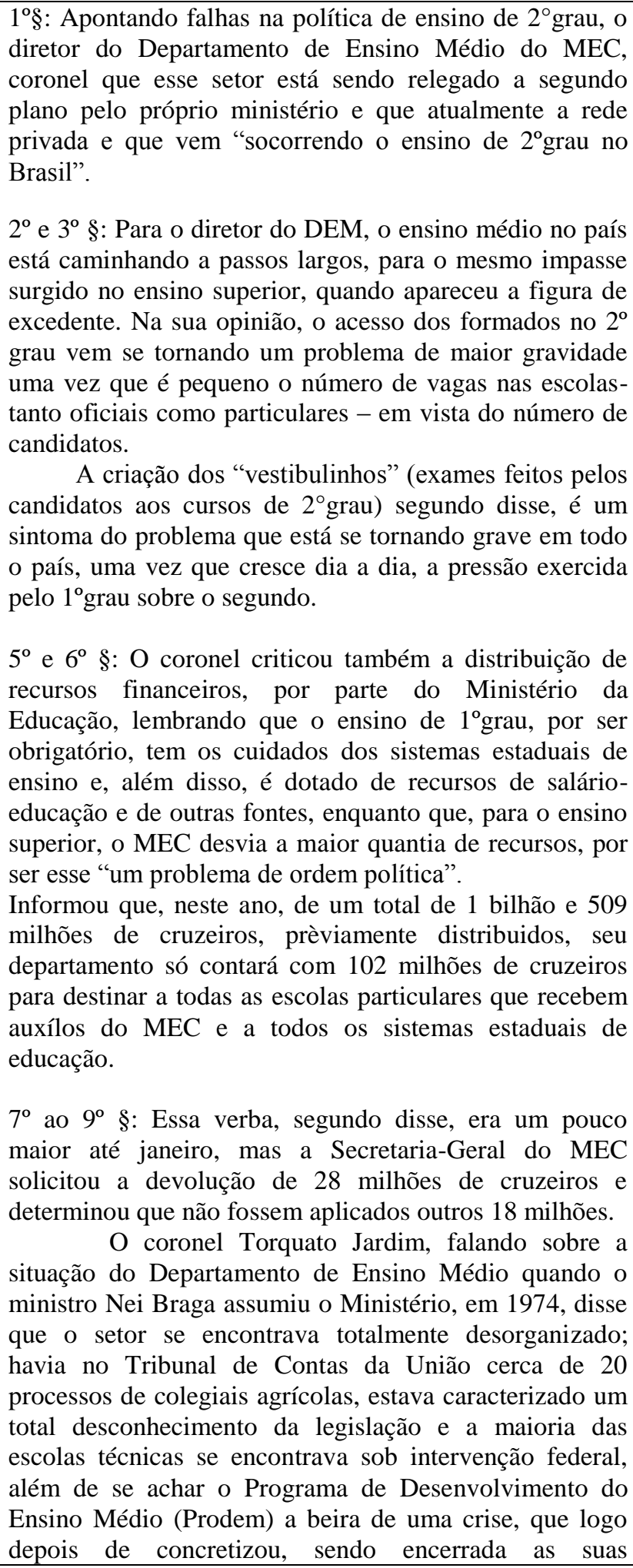 \\
\hline
\end{tabular}




\begin{tabular}{|c|c|c|}
\hline & & 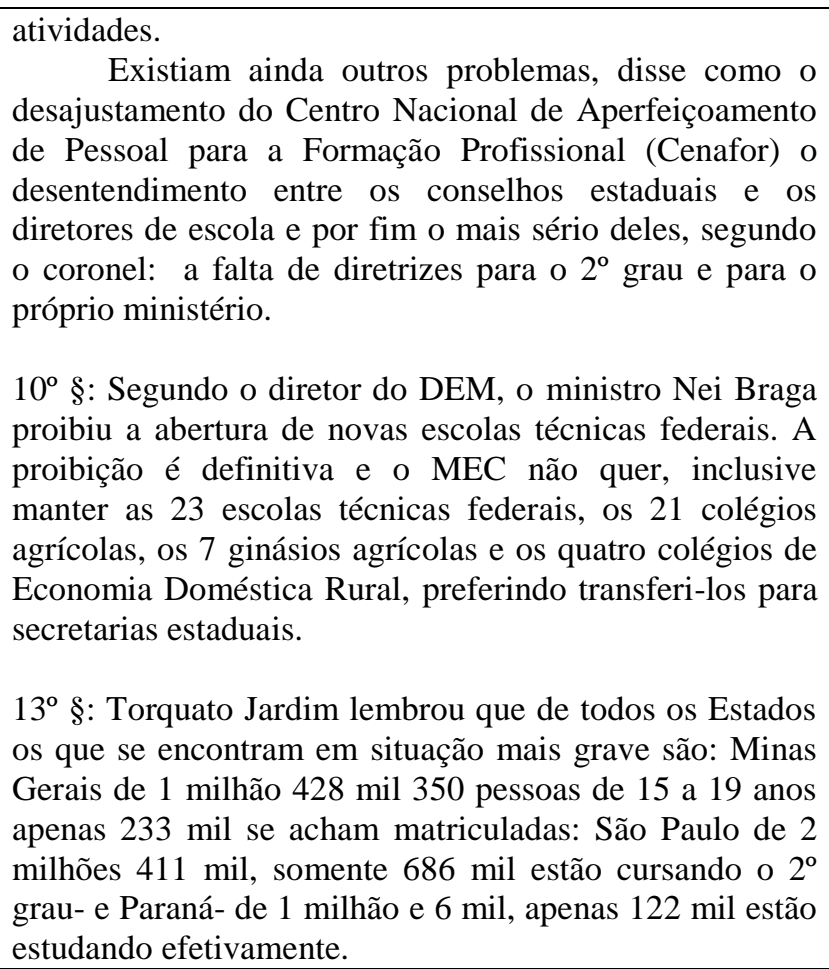 \\
\hline
\end{tabular}

Podemos perceber, diante do quadro exposto acima, que a notícia se compõe quase que por inteiro do discurso indireto em que o autor atribuído a tal discurso é o coronel Torquato Jardins que, no ano de 1978, era o Diretor do Departamento de Ensino Médio (DEM) do MEC. Sendo tal figura representante oficial e pertencente ao Departamento de Educação, tem uma grande tomada de voz dentro do discurso, mesmo sendo pelo discurso citado indireto.

A voz do enunciador tende a desaparecer em determinados pontos do texto para deixar sobressair a voz e a opinião do coronel. Assim, ficam explícitas a força e a legitimidade que Torquato Jardins exerce perante a sociedade brasileira do final da década de 1970. Veremos adiante essas marcas de sobreposição de voz do enunciador versus Diretor do DEM:

Essa verba, segundo disse, era um pouco maior até janeiro, mas a Secretaria-Geral do MEC solicitou a devolução de 28 milhões de cruzeiros e determinou que não fossem aplicados outros 18 milhões.

Segundo o diretor do DEM, o ministro Nei Braga proibiu a abertura de novas escolas técnicas federais. A proibição é definitiva e o MEC não quer, inclusive manter as 23 escolas técnicas federais, os 21 colégios agrícolas, os 7 ginásios agrícolas e os quatro colégios de Economia Doméstica Rural, preferindo transferi-los para secretarias estaduais. (grifo nosso) 
O termo "segundo" de acordo com Grillo (2001) é um modalizador do discurso em que se enuncia a quem pertence aquele discurso, no caso temos um único ator social que é o Diretor do DEM e que perpassa por toda a notícia. É interessante notar que no segundo excerto o diretor do DEM cita a proibição de Nei Braga, o Ministro da Educação do Governo Ernesto Geisel, que de março de 1974 a maio de 1978 criou o Crédito Educativo, o Fundo de Assistência ao Atleta Profissional, o Conselho Nacional de Direitos Autorais. Então, percebemos que há o discurso indireto pertencente ao coronel e dentro de seu discurso uma citação indireta da fala de Nei Braga, que nega a abertura de novas escolas.

Temos, então, o ecoar do discurso sobre o discurso, o dito do que foi dito anteriormente e podemos atrelar a univocidade e a representação oficial ao longo do discurso com a ditatura militar, período em que os militares tomaram o poder e controlavam os meios de comunicação. Tudo estava sob a guarda dos militares, talvez por isso, o jornalista se apoie e se paute mais rigidamente naquilo que foi enunciado por Torquato Jardins, um coronel. 


\subsection{1 - Características marcantes no corpus da década de 1970}

$\mathrm{Na}$ análise do corpus referente à década de 1970, podemos notar o predomínio exaustivo de uma única voz oficial ao longo dos textos. Houve uma contraposição de vozes somente em apenas um único texto, na Notícia 18 (29/04/1977) em que o então Ministro da Educação, o senhor Nei Braga, debate com os senadores sobre a cobrança ou não de mensalidades na escola pública, entre outras questões.

No entanto, podemos perceber que ambas as vozes sociais presentes eram compostas de atores sociais oficiais ligados ao governo, os senadores de um lado, e o Ministro da Educação do outro; portanto, com direito a voz mesmo estando tão divergentes sobre um determinado assunto.

Assim, vimos que ao longo das análises o discurso oficial de direita impera nas notícias, isso é passível de acontecer devido ao regime militarista em que vivia o Brasil na década de 1970, sempre entremeado de cerceamento e controle das mídias, principalmente do jornal que era um veículo de grande poder, talvez até maior do que nos tempos de hoje, sem a massificação e imediatismo da televisão e da internet que toma força no cotidiano do século XXI, período do qual analisaremos o corpus mais detalhadamente no próximo item. 


\section{OBRA COM FOTO DE EVENTO TUCANO INTEGRA PROGRAMA NACIONAL DO LIVRO DIDÁTICO; MINISTÉRIO NEGA HAVER PROPAGANDA}

\begin{tabular}{|c|c|c|}
\hline $\begin{array}{l}\text { Tipo de } \\
\text { discurso } \\
\text { empregado }\end{array}$ & $\begin{array}{l}\text { Ator social atribuído } \\
\text { ao discurso }\end{array}$ & Reprodução do trecho \\
\hline \multirow[t]{4}{*}{$\begin{array}{l}\text { Discurso } \\
\text { indireto }\end{array}$} & $\begin{array}{l}\text { Deputado do PSDB, } \\
\text { Fioverante }\end{array}$ & $\begin{array}{l}2^{\circ} \text { ao } 4^{\circ} \text { §: Fioravante disse que vai entrar com ação } \\
\text { contra o ministro Paulo Renato Souza por crime de } \\
\text { responsabilidade. } \\
\text { Na opinião do deputado petista, recursos públicos } \\
\text { estão sendo utilizados para fazer propaganda do } \\
\text { PSDB em ano pré-eleitoral. "Há um visível } \\
\text { direcionamento político-partidário", } \\
\text { Ministério afirmou. } \\
\text { Segundo Fioravante, também serão impetradas ações } \\
\text { de ressarcimento dos recursos gastos na aquisiçáo do } \\
\text { livro e de apreensão dos exemplares já distribuídos } \\
\text { aos colégios da rese pública. } \\
\text { A Folha procurou o ministro Paulo Renato para falar } \\
\text { sobre o livro, mas sua assessoria de imprensa } \\
\text { informou que quem daria as explicações pelo MEC } \\
\text { seria a secretária de Ensino Fundamental, Iara Prado. }\end{array}$ \\
\hline & $\begin{array}{l}\text { Secretária da Educação, } \\
\text { Iara Prado }\end{array}$ & $\begin{array}{l}\text { Segundo a secretária, o MEC não concorda com a } \\
\text { avaliação de que o livro faz propaganda do PSDB } \\
9^{\circ} \text { e } 10^{\circ} \text { §: A secretária disse que a foto está de acordo } \\
\text { com o tema tratado no capítulo. } \\
\text { Segundo ela, cada livro incluído no guia do MEC - } \\
\text { utilizado pelos professores para escolher as obras - é } \\
\text { analisado por pelo menos dois professores } \\
\text { universitários da área. }\end{array}$ \\
\hline & $\begin{array}{lr}\text { Holien } & \text { Gonçalves } \\
\text { Bezerra, professor } \\
\text { aposentado da } & \text { UFGO } \\
\text { (Universidade } & \text { Federal } \\
\text { de Goiás) } & \\
\end{array}$ & $\begin{array}{l}12^{\circ} \text { §: Um dos consultores que analisaram o livro de } \\
\text { estudos sociais, Holien Gonçalves Bezerra, professor } \\
\text { aposentado da UFGO (Universidade Federal de } \\
\text { Goiás), afirmou que a utilização de uma foto de } \\
\text { congresso do PSDB não caracteriza propaganda, } \\
\text { porque a ilustração está "contextualizada". }\end{array}$ \\
\hline & $\begin{array}{l}\text { Ministério de Educação } \\
\text { e Cultura (MEC) }\end{array}$ & $\begin{array}{l}14^{\circ} \text { §: Pela classificação do MEC, o livro tem uma } \\
\text { estrela. Ou seja, é recomendado, mas com ressalvas - } \\
\text { não tem erros conceituais nem preconceitos, mas os } \\
\text { professores têm de complementar as lições. }\end{array}$ \\
\hline
\end{tabular}




\begin{tabular}{|l|l|l|}
\hline $\begin{array}{l}\text { Discurso } \\
\text { direto }\end{array}$ & $\begin{array}{l}\text { Secretária da Educação, } \\
\text { Iara Prado }\end{array}$ & $\begin{array}{l}7^{\circ} \text { e } 8^{\circ} \text { §: "Não existe proselitismo. O livro foi } \\
\text { avaliado em 1998, no último ano do governo. Nós } \\
\text { nem sabíamos se presidente (Fernando Henrique } \\
\text { Cardoso) seria reeleito", argumentou Iara Prado. } \\
\text { "Se naquela época o autor tivesse escolhido uma foto } \\
\text { do PT e o livro se enquadrasse nos critérios de } \\
\text { exclusão, seríamos acusados de perseguição", } \\
\text { completou. } \\
11^{\circ} \text { \&: "Se há divergências, um terceiro é consultado. } \\
\text { Há livros que passam por até oito consultores", disse } \\
\text { a secretária. }\end{array}$ \\
\hline $\begin{array}{l}13^{\circ} \S: \text { "Não é propaganda de um partido. O texto trata } \\
\text { de partidos políticos, e a foto retrata uma realidade. } \\
\text { Poderia ser uma foto do PT", afirmou. Segundo o } \\
\text { professor, as pessoas que avaliam os livros "nem são } \\
\text { do governo". }\end{array}$ \\
\hline
\end{tabular}

Neste texto, é possível perceber a maior diversificação de atores sociais atribuídos aos discursos, sejam eles diretos ou indiretos com relação às décadas de 1930, 1940 e 1970. Na primeira década do século XXI a contraposição de vozes é um elemento marcante nos textos. Portanto, temos a voz do deputado Waldomiro Fioverante (PT/RS), no $2^{\circ}$ e $3^{\circ}$ parágrafos, um discurso indireto em que ele ameaça processar o Ministro da Educação, Paulo Renato Souza por ter usado dinheiro público para realizar propaganda pré-eleitoral, colocando no livro didático uma foto do congresso do PSDB.

No $5^{\circ}$ parágrafo, vemos a FSP como investigadora e como fonte de confiabilidade e solidez perante os fatos, pois é ela quem vai entrevistar as partes para saber a "verdade" e isso fica claro no trecho que se segue:

A Folha procurou o ministro Paulo Renato para falar sobre o livro, mas sua assessoria de imprensa informou que quem daria as explicações pelo MEC seria a secretária de Ensino Fundamental, Iara Prado.

O segundo ator social a aparecer no texto, conforme o excerto anterior, seria o do ministro Paulo Renato, no entanto quem acabou respondendo e se defendendo das acusações feitas por Fioverante foi a secretária de Ensino Fundamental Iara Prado.

O terceiro ator social a aparecer é o professor aposentado Holien Gonçalves Bezerra que participou da análise dos livros de Estudos Sociais, o que desvincula a avaliação do governo. E o quarto ator social foi a "classificação do MEC"; o uso do 
documento pela pessoa corrobora a teoria de uma desvinculação de qualquer tendência política.

Quanto aos verbos introdutórios de opinião, temos: "afirmou" para o ator social Fioverante e para o professor Bezerra que caracteriza, segundo Marcuschi (2007): "Verbos indicadores de posições oficiais e afirmações positivas"; no caso aqui, todos os atores sociais são oficiais, pois pertencem ao governo, mesmo se tratando de partidos políticos contrários.

O uso de "segundo" é empregado para Fioverante, no $9^{\circ}$ parágrafo para secretária de ensino Iara Prado e para o professor Holien Gonçalves Bezerra, segundo Grilllo (2001), tal uso seria um modalizador que tem como característica específica enviar a um outro discurso, ou seja, enunciar um outro discurso.

Com esses modalizadores levantados no parágrafo anterior, podemos perceber que o enunciador não se vale de uma diversidade de modalizadores, limitando-se a usar quase sempre os mesmos. Talvez com isso se queira transmitir uma neutralidade diante de uma luta de dois partidos políticos que têm uma grande representação no país.

\section{NOTÍCIA 22- 16/04/2002}

MÃES PEDEM A REPROVAÇÃO DOS FILHOS, ALEGANDO QUE ELES NÃO APRENDERAM A LER MESMO DEPOIS DE VÁRIOS ANOS NA ESCOLA

\begin{tabular}{|l|lr|l|}
\hline $\begin{array}{l}\text { Tipo de } \\
\text { discurso } \\
\text { empregado }\end{array}$ & $\begin{array}{l}\text { Ator } \\
\text { atribuído } \\
\text { discurso }\end{array}$ & $\begin{array}{r}\text { social } \\
\text { ao }\end{array}$ & Reprodução do trecho \\
\hline $\begin{array}{l}\text { Discurso } \\
\text { indireto }\end{array}$ & $\begin{array}{l}\text { Recepcionista } \\
\text { Cristina, mãe de D. } \\
12\end{array}$ & $\begin{array}{l}2^{\circ} \text { ao } 6^{\circ} \text { §: São casos como o da recepcionista Maria } \\
\text { Cristina, mãe de D., 12. Ela pediu que D. não fosse para } \\
\text { a quinta série, apesar de já ter cursado a quarta série duas } \\
\text { vezes. Isso aconteceu em janeiro, no município de } \\
\text { Votorantim (a 108 km de São Paulo), na Escola } \\
\text { Municipal Abimael Carlos de Campos. } \\
\text { A mãe apresentou um motivo bem simples para que seu } \\
\text { pedido fosse atendido: o filho, mesmo depois de cinco } \\
\text { anos na escola, não sabia ler nem escrever. A cidade } \\
\text { adotou o regime de progressão continuada em 1998, em } \\
\text { conjunto com o Estado. } \\
\text { O menino, segundo a mãe, apresentava dificuldades de } \\
\text { aprendizagem desde que começou a estudar. Mas, afirma } \\
\text { ela, D. nunca recebeu apoio médico ou psicológico na } \\
\text { escola. }\end{array}$ \\
\hline
\end{tabular}




\begin{tabular}{|c|c|c|}
\hline & & $\begin{array}{l}\text { D. acabou sendo reprovado em 2000, quando se } \\
\text { submeteu pela primeira vez a uma avaliação, já na quarta } \\
\text { série. No ano seguinte, segundo a mãe, o menino } \\
\text { continuava na mesma situação: sem saber ler ou } \\
\text { escrever. Mesmo assim, a aprovação para a quinta série } \\
\text { foi automática -pelas regras atuais, um aluno só pode } \\
\text { repetir uma determinada série uma única vez. A pedido e } \\
\text { insistência da mãe, ele foi novamente matriculado na } \\
\text { quarta série. }\end{array}$ \\
\hline & $\begin{array}{l}\text { Secretária municipal } \\
\text { da Educação de } \\
\text { Votorantim, Neuza } \\
\text { Aparecida Móra }\end{array}$ & $\begin{array}{l}6^{\circ} \text { §: Segundo a secretária municipal da Educação de } \\
\text { Votorantim, Neuza Aparecida Móra, além de D., foram } \\
\text { detectadas outras } 53 \text { crianças da quarta série (de um total } \\
\text { de 1.827) que não tinham condições de passar para o } \\
\text { ciclo seguinte. Como já haviam repetido um ano durante } \\
\text { o ciclo, mesmo com deficiências, matricularam-se na } \\
\text { quinta série. }\end{array}$ \\
\hline & $\begin{array}{l}\text { Grupo de } 25 \text { mães e } \\
\text { Walter Colombini, } \\
\text { presidente } \\
\text { conselho }\end{array}$ & $\begin{array}{l}7^{\circ} \text { §: Em Ribeirão Preto (a } 314 \mathrm{~km} \text { de São Paulo), um } \\
\text { grupo de } 25 \text { mães procurou o Conselho Municipal de } \\
\text { Educação para reclamar que os filhos também não } \\
\text { haviam sido alfabetizados. Segundo Walter Colombini, } \\
\text { presidente do conselho, um desses alunos já terminou a } \\
\text { oitava série. }\end{array}$ \\
\hline & $\begin{array}{l}\text { Promotor Serrano } \\
\text { Junior }\end{array}$ & $\begin{array}{l}11^{\circ} \S \text { : A tese do promotor Serrano Junior é que cada } \\
\text { escola, em integração com a comunidade de pais de } \\
\text { alunos, pode elaborar a forma de avaliação a ser adotada. }\end{array}$ \\
\hline & A mãe disse à Folha & $\begin{array}{l}8^{\circ} \text { §: L., 13, que está na sexta série, repetiu a quarta na } \\
\text { Escola Estadual Cordelia Ribeiro Ragoso, em Bonfim } \\
\text { Paulista (distrito de Ribeirão Preto). O menino aprendeu } \\
\text { a copiar letras, mas lê como um aluno da primeira série, } \\
\text { disse a mãe à Folha. }\end{array}$ \\
\hline & 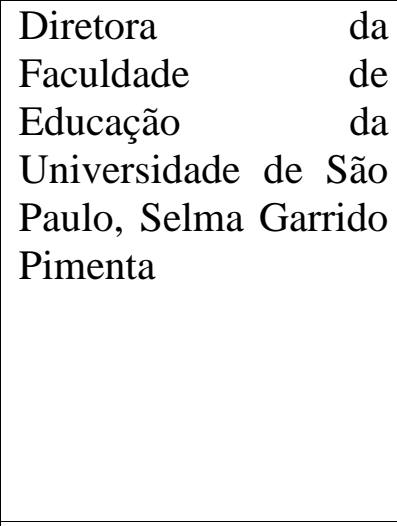 & $\begin{array}{l}13^{\circ} \text { ao } 15^{\circ} \text { §: A progressão continuada está "refinando" o } \\
\text { processo de exclusão social no Estado, afirma a diretora } \\
\text { da Faculdade de Educação da Universidade de São } \\
\text { Paulo, Selma Garrido Pimenta. } \\
\text { Ela questiona o fato de que, mesmo recomendado pela } \\
\text { LDB, o modelo de progressão por ciclos tenha sido } \\
\text { adotado apenas na rede pública. A seu ver, isso joga para } \\
\text { o vestibular a efetiva comparação entre as metodologias } \\
\text { de ensino das redes pública e particular. } \\
\text { Outro item apontado por Selma é a forma de } \\
\text { implementação do sistema no Estado. Não houve, de } \\
\text { acordo com a educadora, "significativas alterações" na } \\
\text { forma de a escola se organizar e funcionar. }\end{array}$ \\
\hline & $\begin{array}{l}\text { Maria } r \text { Isabel } \\
\text { Noronha, presidente } \\
\text { da Apeoesp }\end{array}$ & $\begin{array}{l}17^{\circ} \text { e } 18^{\circ} \S: \text { Maria Isabel Noronha, presidente da } \\
\text { Apeoesp (Sindicato dos Professores do Ensino Oficial de } \\
\text { São Paulo), concorda com Selma: o problema está na } \\
\text { forma como o regime foi introduzido. } \\
\text { Antes da implantação, afirma, deveria haver mudanças } \\
\text { nas condições estruturais das escolas, como a diminuição } \\
\text { do número de alunos por sala de aula e o aumento do } \\
\text { salário dos professores. }\end{array}$ \\
\hline $\begin{array}{l}\text { Discurso } \\
\text { direto }\end{array}$ & $\begin{array}{l}\text { Promotor Serrano } \\
\text { Junior }\end{array}$ & $\begin{array}{l}12^{\circ} \S \text { "Em princípio, a idéia é fortalecer a ligação entre a } \\
\text { escola e a comunidade, o que é recomendado pela Lei de } \\
\text { Diretrizes e Bases da Educação", afirmou o promotor. }\end{array}$ \\
\hline
\end{tabular}




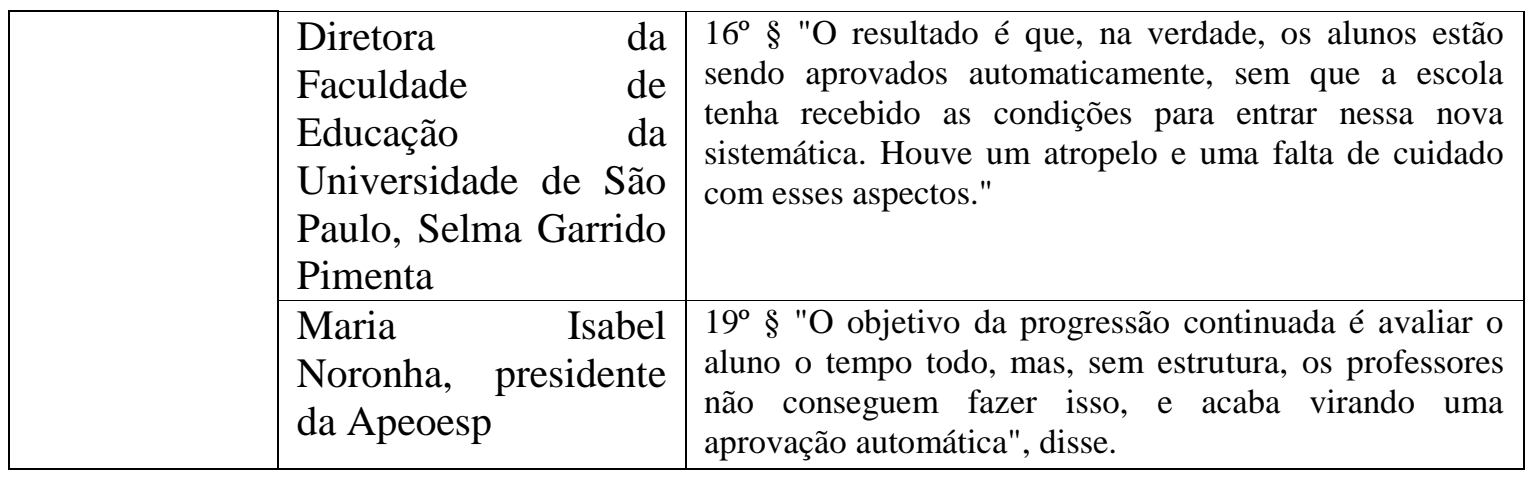

\section{OUTRO LADO}

\begin{tabular}{|c|c|c|}
\hline $\begin{array}{l}\text { Tipo de } \\
\text { discurso } \\
\text { empregado }\end{array}$ & $\begin{array}{lr}\text { Ator } & \text { social } \\
\text { atribuído } & \text { ao } \\
\text { discurso } & \\
\end{array}$ & Reprodução do trecho \\
\hline $\begin{array}{l}\text { Discurso } \\
\text { indireto }\end{array}$ & $\begin{array}{l}\text { Secretário- } \\
\text { adjunto da } \\
\text { Educação do } \\
\text { Estado de } \\
\text { Paulo, }\end{array}$ & $\begin{array}{l}2^{\circ} \text { e } 3^{\circ} \S \text { Além disso, para o dirigente, o problema estaria na } \\
\text { escola, já que cada aluno teve quatro professores, um } \\
\text { coordenador pedagógico e um diretor acompanhando sua vida } \\
\text { escolar no período. Essa equipe é que será "acionada" para } \\
\text { verificar responsabilidades administrativas. } \\
\text { Segundo Alqueres, os resultados do Saresp de } 1998 \text { e } 2001 \\
\text { jogam uma pá de cal sobre as críticas à progressão continuada. } \\
\text { A média de acertos dos alunos, que era de } 48,5 \% \text { das questões, } \\
\text { aumentou para } 54,5 \% \text { e } 55,7 \% \text { na primeira e segunda fases do } \\
\text { exame, respectivamente. }\end{array}$ \\
\hline $\begin{array}{l}\text { Discurso } \\
\text { direto }\end{array}$ & $\begin{array}{l}\text { Secretário- } \\
\text { adjunto da } \\
\text { Educação do } \\
\begin{array}{ll}\text { Estado de } & \text { São } \\
\text { Paulo } & \end{array}\end{array}$ & $\begin{array}{l}4^{\circ} \S \text { "Após quatro anos, os alunos tinham aprendido mais. Isso } \\
\text { não significa que não existam casos problemáticos, em que não } \\
\text { seja atingido um desempenho satisfatório. Nesses casos } \\
\text { pontuais, os alunos têm de passar por recuperação de ciclo. } \\
\text { Pretendemos acionar as escolas para ver o que está } \\
\text { acontecendo. Se percebermos que é uma forma de "boicote", aí } \\
\text { teremos de cobrar responsabilidade." (ID) }\end{array}$ \\
\hline
\end{tabular}

Logo no subtítulo da notícia, vemos o discurso indireto de mães de alunos que pedem a reprovação de seus respectivos filhos, porque eles não sabem ler. O jornalista apresenta no $2^{\circ}$ parágrafo a mãe e recepcionista Maria Cristina, individualizando-a. Tal fenômeno na primeira década do século XXI é passível de acontecer por ser marcado pela contraposição de vozes e opinião dentro do gênero notícia. No entanto, isso seria muito difícil de ocorrer nas décadas de 1930, 1940 e 1970.

Já no $6^{\circ}$ parágrafo, temos o ator social Neuza Aparecida Mora, que é secretária da Educação do Município de Votorantim, dizendo sobre as complicações da "progressão automática". No entanto, se houve uma identificação e individualização de uma mãe anteriormente no texto, no $7^{\circ}$ parágrafo aparecem atores sociais intitulados “25 mães”, não individualizadas, reclamando sobre a não-alfabetização de seus filhos na cidade de Ribeirão Preto. Na retranca intitulada "Copiar letras", temos: 
L., 13, que está na sexta série, repetiu a quarta na Escola Estadual Cordelia Ribeiro Ragoso, em Bonfim Paulista (distrito de Ribeirão Preto). O menino aprendeu a copiar letras, mas lê como um aluno da primeira série, disse a mãe à Folha.

Podemos perceber pelo excerto exposto anteriormente que temos a individualização da escola, e do aluno - este parcialmente - devido a ser menor de idade; no entanto, a mãe também não foi individualizada dentre as "25 mães" relatadas anteriormente.

Na retranca "Inquérito", temos o promotor Serrano Junior primeiro em discurso indireto e, no parágrafo seguinte, em discurso direto que tem como "verbo introdutório de opinião" o verbo "afirmou" que indica "posições oficiais e afirmações positivas", segundo Marcushi (2007). Podemos perceber que se trata de uma voz de autoridade oficial por ser a de um promotor e, além disso, conhecedor da Lei de Diretrizes e Bases da Educação, podendo responder com propriedade sobre o assunto.

O mesmo é válido para o ator social Selma Garrido Pimenta, diretora da Faculdade de Educaçao da USP, na retranca chamada "Exclusão social" é usado o verbo "afirmar" como um elemento que confirma uma posição oficial e detentora do tema. O segundo verbo usado para modalizar sua voz é o verbo "questionar" que estaria ligado a "verbos indicadores de retomadas opositivas, organizadores dos aspectos conflituosos" (Marcuschi, 2007).

Um modalizador presente é o "de acordo com a educadora" (grifo nosso), no $15^{\circ}$ parágrafo, que tem a função de remeter a outro discurso, no caso ao da diretora. Dessa forma, o enunciador se afasta da opinião de Selma como uma forma de se ausentar sem qualquer tomada de partido.

O último ator social presente no texto é Maria Isabel Noronha, presidente da Apeoesp, também é introduzida a sua opinião com o verbo "afirmar", e é também um ator social oficial mesmo não pertencente ao governo, pois ela é presidente de um sindicato muito expressivo no Estado de São Paulo. O verbo "concordar" que está atrelado à figura da diretora da Faculdade de Educação da USP demonstra que as duas educadoras corroboram da mesma tese: quais os rumos que a progressão continuada deveria ter tomado. 
Quanto à seção "Outro Lado", temos a negação do fracasso da progressão continuada logo no subtítulo sob forma de discurso indireto do Secretário-adjunto do Estado de São Paulo, o senhor Hubert Alqueres. No $3^{\circ}$ parágrafo, temos a expressão "segundo Alqueres" (grifo nosso) que já foi mencionada nesta análise como um modalizador que tem a função de enviar o discurso a outro. Dessa forma, o enunciador se afasta de qualquer resquício negativo que tal opinião possa apontar sobre ele. Além disso, o secretário-adjunto se vale dos resultados do Saresp que podem ser questionados a partir de fatores extra-oficiais.

NOTÍCIA 23- 17/03/2004

EM NOVEMBRO, MEC VAI AVALIAR ALUNOS DE 13 CURSOS NO PAÍS

\begin{tabular}{|c|c|c|}
\hline $\begin{array}{l}\text { Tipo de } \\
\text { discurso } \\
\text { empregado }\end{array}$ & $\begin{array}{l}\text { Ator social atribuído } \\
\text { ao discurso }\end{array}$ & Reprodução do trecho \\
\hline $\begin{array}{l}\text { Discurso } \\
\text { indireto } \\
\text { seguido } \\
\text { direto } \\
\text { indireto }\end{array}$ & $\begin{array}{lr}\text { Paulo Renato Souza, } \\
\text { ex-ministro } \\
\text { Educação nos dois } \\
\text { mandatos de Fernando } \\
\text { Henrique Cardoso } \\
(1995-2002)\end{array}$ & $\begin{array}{l}1^{\circ} \S \text { : Alguns especialistas, no entanto, consideram o } \\
\text { novo sistema como mera sequiência daquele que } \\
\text { instituiu o Provão. "O que há de novo no sistema? } \\
\text { Não há nada. Tudo já vinha sendo feito, inclusive a } \\
\text { avaliação da responsabilidade social. Não há muito o } \\
\text { que inventar nessa área", avalia Paulo Renato Souza, } \\
\text { ex-ministro da Educação nos dois mandatos de } \\
\text { Fernando Henrique Cardoso (1995-2002) e } \\
\text { responsável pelo implemento do antigo sistema de } \\
\text { avaliação do ensino superior. }\end{array}$ \\
\hline \multirow[t]{3}{*}{$\begin{array}{l}\text { Discurso } \\
\text { direto }\end{array}$} & $\begin{array}{lr}\text { Afrânio } & \text { Catani, } \\
\text { professor } & \text { na } \\
\text { Faculdade } & \text { de } \\
\text { Educação da USP } & \end{array}$ & $\begin{array}{l}3^{\circ} \text { §: Afrânio Catani, professor na Faculdade de } \\
\text { Educação da USP e membro do Fórum de Políticas } \\
\text { Públicas, diz que "o sistema é um misto do Provão } \\
\text { com a proposta original do Sinaes (apresentada por } \\
\text { uma comissão criada pelo MEC), que perdeu suas } \\
\text { características essenciais". }\end{array}$ \\
\hline & $\begin{array}{l}\text { Gustavo Petta, } \\
\text { presidente da UNE }\end{array}$ & $\begin{array}{l}5^{\circ} \text { §: "É um avanço condicionado ao peso que será } \\
\text { dado à prova no índice final de avaliação", afirma } \\
\text { Gustavo Petta, presidente da UNE (União Nacional } \\
\text { dos Estudantes), entidade historicamente contrária ao } \\
\text { Provão. }\end{array}$ \\
\hline & $\begin{array}{l}\text { Reitor da Unicamp, } \\
\text { Carlos Henrique de } \\
\text { Brito Cruz. }\end{array}$ & $\begin{array}{l}8^{\circ} \text { §: "É complicado usar amostragem", avalia o reitor } \\
\text { da Unicamp, Carlos Henrique de Brito Cruz. "Como } \\
\text { será feita a cobertura? É uma avaliação relativa." }\end{array}$ \\
\hline
\end{tabular}




\begin{tabular}{|c|c|c|}
\hline $\begin{array}{l}\text { Discurso } \\
\text { direto }\end{array}$ & Paulo Renato Souza & $\begin{array}{l}12^{\circ} \text { §: Para, o problema será a implementação. "A lei } \\
\text { é boa porque acolhe o que o Provão fazia e abre } \\
\text { alternativas. A questão é saber a linha que o governo } \\
\text { vai adotar [na regulamentação da proposta]." }\end{array}$ \\
\hline \multirow[t]{2}{*}{$\begin{array}{l}\text { Discurso } \\
\text { indireto }\end{array}$} & $\begin{array}{l}\text { Equipe do Ministério } \\
\text { da Educação }\end{array}$ & $\begin{array}{l}2^{o} \text { §: Para a atual equipe do Ministério da Educação, o } \\
\text { Sinaes é um avanço, pois possibilita visão integrada } \\
\text { do aluno, infra-estrutura e qualidade de ensino ao } \\
\text { estabelecer um único índice de avaliação. }\end{array}$ \\
\hline & $\begin{array}{l}\text { Professor Daltro José } \\
\text { Nunes, da } \\
\text { Universidade Federal } \\
\text { do Rio Grande do Sul }\end{array}$ & $\begin{array}{l}11^{\circ} \text { §: Como ainda não estão definidos, os conceitos } \\
\text { ideais a serem aplicados no Sinaes geram dúvidas. } \\
\text { Uma preocupação para o professor Daltro José Nunes, } \\
\text { da Universidade Federal do Rio Grande do Sul, é a } \\
\text { definição do conceito de responsabilidade social, } \\
\text { aplicado na avaliação da instituição segundo o novo } \\
\text { sistema. }\end{array}$ \\
\hline \multirow[t]{2}{*}{$\begin{array}{l}\text { Discurso } \\
\text { indireto } \\
\text { seguido de } \\
\text { direto }\end{array}$} & $\begin{array}{l}\text { Gustavo Petta, } \\
\text { presidente da UNE }\end{array}$ & $\begin{array}{l}6^{\circ} \S: \text { Para ele, o fato de o projeto ter sido construído } \\
\text { coletivamente democratizou a avaliação. "Mas esse } \\
\text { avanço democrático é contraditório à permanência da } \\
\text { obrigatoriedade do exame." }\end{array}$ \\
\hline & $\begin{array}{l}\text { Adolpho José Melfi, } \\
\text { reitor da USP }\end{array}$ & $\begin{array}{l}10^{\circ} \text { §: Para Adolpho José Melfi, reitor da USP, "falta } \\
\text { uma avaliação que indique mudanças nos rumos da } \\
\text { universidade". Esse tipo de diretriz, segundo ele, a } \\
\text { USP conseguiu com auto-avaliações. } \\
\text { "O projeto é um passo à frente, mas ainda precisa de } \\
\text { ajustes", diz Paulo Alcântara Gomes, presidente do } \\
\text { Crub (Conselho de Reitores das Universidades } \\
\text { Brasileiras). Desde 2001, o Crub implantou um } \\
\text { sistema de avaliação. A partir de seu resultado, as } \\
\text { instituições se propõem a mudar aquilo avaliado como } \\
\text { insuficiente. }\end{array}$ \\
\hline $\begin{array}{l}\text { Discurso } \\
\text { direto seguido } \\
\text { de indireto }\end{array}$ & $\begin{array}{l}\text { Adolpho José Melfi, } \\
\text { reitor da USP }\end{array}$ & $\begin{array}{l}9^{\circ} \S \text { Para Adolpho José Melfi, reitor da USP, "falta } \\
\text { uma avaliação que indique mudanças nos rumos da } \\
\text { universidade". Esse tipo de diretriz, segundo ele, a } \\
\text { USP conseguiu com auto-avaliações }\end{array}$ \\
\hline
\end{tabular}

Verificamos no $1^{\circ}$ parágrafo deste texto a voz de autoridade de Paulo Renato Souza, ex- ministro da Educação e responsável pela implantação do Provão. Com sua voz de autoridade, ele afirma e ao mesmo tempo diverge em discurso direto, dizendo que: "não há muito que inventar nessa área" demonstrando sua superioridade por ser o precursor desse tipo de avaliação. É notável o prestígio que Paulo Renato ainda detém perante a mídia, pois no $2^{\circ}$ parágrafo se enuncia a "atual equipe do Ministério"; no entanto, nenhum nome foi destacado ou individualizado, nem ao menos o do Ministro da Educação vigente: Tarso Genro. 
No $3^{\circ}$ parágrafo o ator social que aparece no texto é o professor Afrânio Catani da Faculdade de Educação da USP, que também critica o novo sistema de avaliação do curso superior. Na retranca intitulada "Enade", aparecem vários atores sociais contrários ou fazendo ressalvas a essa avaliação, temos então: Carlos Henrique Brito Cruz, reitor da Unicamp; Adolpho José Melfi, reitor da USP; Daltro José Nunes, professor da Universidade Federal do Rio Grande do Sul e, por último, o retorno de um discurso direto de Paulo Renato.

A única voz que aparece no texto sendo pró-Enade foi a de Gustavo Petta, presidente da União Nacional dos Estudantes, mas mesmo assim com ressalvas diante da obrigatoriedade do exame. Portanto, podemos perceber pelas vozes elencadas pelo enunciador e suas opiniões que o próprio jornalista também tende a ter opinião negativa diante das perspectivas do Enade: a nova avaliação do ensino superior.

Quanto aos verbos introdutórios de opinião, temos: o verbo "avaliar" que, segundo Marcuschi (2007), seria um “verbo que indica provisoriedade do argumento", ou seja, eles supõem que a avaliação tenha falhas, mas não afirmam categoricamente. Esse verbo foi usado para os atores sociais Paulo Renato, para o reitor da Unicamp e Gustavo Petta.

Já o modalizador "para", que tem a função de enviar a um outro discurso, segundo Grillo (2001), foi usado para introduzir a voz de vários atores sociais presentes no texto, tais como: "Paulo Renato", "atual equipe no Ministério da Educação", “Gustavo Petta”, “Adolpho José Melfi”, "Daltro José Nunes”, "Paulo Renato Souza”. Notamos que o modalizador foi usado quase que para todos os atores sociais presentes no texto, o que pode nos levar a considerar que esse uso pode sido realizado para "camuflar" alguma diferença de tratamento entre os atores por parte do enunciador. 
NOTÍCIA 24- 27/04/2004

\section{SÃO ATRIBUÍDOS À COMISSÃO QUE ANALISA OBRAS DE CIÊNCIAS DESDE ERROS CONCEITUAIS ATÉ CRÍTICAS QUE NÃO PROCEDEM}

\begin{tabular}{|c|c|c|}
\hline $\begin{array}{ll}\text { Tipo de } & \text { discurso } \\
\text { empregado } & \end{array}$ & $\begin{array}{lr}\text { Ator } & \text { social } \\
\text { atribuído } & \text { ao } \\
\text { discurso } & \end{array}$ & Reprodução do trecho \\
\hline \multirow[t]{4}{*}{$\begin{array}{l}\text { Discurso } \\
\text { indireto }\end{array}$} & $\begin{array}{l}\text { Presidente da } \\
\text { Abrale, Gelson } \\
\text { Iezzi }\end{array}$ & $\begin{array}{l}1^{\circ} \S \text { O presidente da Abrale, Gelson Iezzi, diz que a entidade } \\
\text { não é contra a avaliação, que funciona, segundo ele, como um } \\
\text { autocontrole para as editoras e autores, melhorando a } \\
\text { qualidade dos livros didáticos. Quer, sim, que ela seja revista, } \\
\text { principalmente em dois pontos: a escolha dos membros da } \\
\text { comissão, cujas bases, alega, não são claras, e a sistemática do } \\
\text { processo de análise. }\end{array}$ \\
\hline & Abrale & $\begin{array}{l}3^{\circ} \S \text { Em relação ao processo de avaliação, a Abrale defende } \\
\text { que ele seja contínuo e possibilite aos autores e editoras } \\
\text { responder às críticas e corrigir eventuais erros antes de o livro } \\
\text { ser excluído da lista do MEC por causa desses problemas. } \\
6^{\circ} \text { e } 7^{\circ} \S \text { A Abrelivros (associação das editoras) não subscreve } \\
\text { o documento da Abrale, embora defenda algumas das } \\
\text { mudanças estruturais propostas por ele, como o direito de } \\
\text { réplica e alteração do cronograma das avaliações. }\end{array}$ \\
\hline & Abrelivros & $\begin{array}{l}\text { Para ilustrar as deficiências do atual modelo de avaliação, a } \\
\text { Abrale cita no seu documento o que considera erros cometidos } \\
\text { pela comissão de ciências. }\end{array}$ \\
\hline & $\begin{array}{lr}\text { Vice- } & \\
\text { presidente } & \text { da } \\
\text { Abrale, } & \text { Vera } \\
\text { Duarte } & \text { de } \\
\text { Novai } & \end{array}$ & $\begin{array}{l}\text { O documento cita o que considera outros erros conceituais e } \\
\text { de avaliação metodológica. Segundo a vice-presidente da } \\
\text { Abrale, Vera Duarte de Novais, a crítica está centrada nos } \\
\text { livros de ciências porque são o caso mais emblemático de } \\
\text { problemas na avaliação, mas ela se aplica a todas as as án } \\
\text { disciplinas. "O modelo é extremamente frágil e vulnerável", } \\
\text { sustenta. }\end{array}$ \\
\hline $\begin{array}{l}\text { Discurso } \\
\text { indireto } \\
\text { seguido de } \\
\text { direto e indireto }\end{array}$ & $\begin{array}{l}\text { Presidente da } \\
\text { Abrale, Gelson } \\
\text { Iezzi }\end{array}$ & $\begin{array}{l}2^{\circ} \S \text { Segundo ele, entre os avaliadores nomeados por Bizzo, a } \\
\text { maioria está em cursos de pós-graduação, sem experiência em } \\
\text { sala de aula. "Não há critério para escolha nem para a } \\
\text { continuidade do grupo", afirma. O ideal, diz, é que } \\
\text { participassem da comissão também representantes das escolas, } \\
\text { professores e de entidades da sociedade civil. }\end{array}$ \\
\hline $\begin{array}{l}\text { Discurso } \\
\text { indireto } \\
\text { seguido } \\
\text { direto }\end{array}$ & $\begin{array}{l}\text { Presidente da } \\
\text { Abrale, Gelson } \\
\text { Iezzi }\end{array}$ & $\begin{array}{l}8^{\circ} \S \mathrm{O} \text { documento cita o que considera outros erros } \\
\text { conceituais e de avaliação metodológica. Segundo a vice- } \\
\text { presidente da Abrale, Vera Duarte de Novais, a crítica está } \\
\text { centrada nos livros de ciências porque são o caso mais } \\
\text { emblemático de problemas na avaliação, mas ela se aplica a } \\
\text { todas as disciplinas. "O modelo é extremamente frágil e } \\
\text { vulnerável", sustenta. }\end{array}$ \\
\hline Discurso direto & $\begin{array}{l}\text { Presidente da } \\
\text { Abrale, Gelson } \\
\text { Iezzi }\end{array}$ & $\begin{array}{l}4^{\circ} \S \text { "Em vez de avaliação, queremos uma certificação } \\
\text { ininterrupta, não necessariamente vinculada à compra dos } \\
\text { livros, o que evitaria correria por parte dos autores na } \\
\text { elaboração dos textos e possibilitaria também às escolas ter } \\
\text { mais tempo para conhecer e escolher as publicações } \\
\text { aprovadas", defende. }\end{array}$ \\
\hline
\end{tabular}




\section{OUTRO LADO}

\begin{tabular}{|c|c|c|}
\hline $\begin{array}{l}\text { Tipo de } \\
\text { discurso } \\
\text { empregado }\end{array}$ & $\begin{array}{lr}\text { Ator } & \text { social } \\
\text { atribuído } & \text { ao } \\
\text { discurso } & \end{array}$ & Reprodução do trecho \\
\hline \multirow[t]{3}{*}{$\begin{array}{l}\text { Discurso } \\
\text { indireto }\end{array}$} & $\begin{array}{lr}\text { Secretária } & \text { de } \\
\text { Educação } & \\
\text { Fundamental do } \\
\text { MEC, Maria } \\
\text { Vieira Feres }\end{array}$ & $\begin{array}{l}1^{\circ} \text { §: Em resposta oficial ao documento que questiona a } \\
\text { avaliação dos livros didáticos de ciências, enviado à } \\
\text { Abrale, a secretária de Educação Fundamental do MEC, } \\
\text { Maria José Vieira Feres, defende o processo de análise e } \\
\text { diz que seus resultados já foram contestados na Justiça, } \\
\text { sem sucesso. }\end{array}$ \\
\hline & $\begin{array}{l}\text { O coordenador da } \\
\text { comissão que } \\
\text { analisa os livros, } \\
\text { Nélio Bizzo }\end{array}$ & $\begin{array}{l}2^{\circ} \S \text { : O coordenador da comissão que analisa os livros, } \\
\text { professor Nélio Bizzo, notificou extrajudicialmente a } \\
\text { associação dos autores pedindo uma retratação pública, } \\
\text { por entender que o documento enviado ao ministério e } \\
\text { publicado no site da Abrale ataca sua credibilidade e sua } \\
\text { imagem profissional. }\end{array}$ \\
\hline & $\begin{array}{l}\text { Abrale } \\
\text { Nélio Bizzo }\end{array}$ & $\begin{array}{l}6^{\circ} \text { §: Em resposta à notificação encaminhada por Nélio } \\
\text { Bizzo, a Abrale afirmou que não teve intenção de denegrir } \\
\text { a imagem dele, mas de mostrar a necessidade de ampliar o } \\
\text { diálogo entre autores e avaliadores. Disseram-se dispostos } \\
\text { também a publicar a notificação e a resposta da entidade. } \\
8^{\circ} \text { §: Para Bizzo, os autores que criticam o processo estão } \\
\text { "bravos" por terem sido rejeitados e precisarem devolver } \\
\text { os direitos autorais antecipados pelas editoras -o que os } \\
\text { autores negam. Ele diz que, embora não interfira } \\
\text { diretamente no processo, analisa os pareceres da comissão } \\
\text { de avaliação e nunca viu problemas que não estivessem } \\
\text { bem justificados. }\end{array}$ \\
\hline $\begin{array}{l}\text { Discurso } \\
\text { direto seguido } \\
\text { de indireto }\end{array}$ & MEC & $\begin{array}{l}3^{0} \text { §: O MEC diz que "a avaliação passa por constantes } \\
\text { reformulações", que incluem revisão dos critérios, dos } \\
\text { procedimentos e também dos representantes da comissão e } \\
\text { das coordenações de área e institucional. O documento } \\
\text { assinado por Feres diz ainda que as equipes de avaliadores } \\
\text { são formadas por especialistas conceituados e respeitados. }\end{array}$ \\
\hline \multirow[t]{2}{*}{$\begin{array}{l}\text { Discurso } \\
\text { indireto } \\
\text { seguido de } \\
\text { direto }\end{array}$} & $\begin{array}{l}\text { A advogada de } \\
\text { Bizzo, Beatriz de } \\
\text { Abreu Dallari } \\
\text { Guerreiro }\end{array}$ & $\begin{array}{l}7^{\circ} \text { §: A advogada de Bizzo, Beatriz de Abreu Dallari } \\
\text { Guerreiro, afirma que uma ação por danos morais é uma } \\
\text { alternativa em estudo, caso não julgue suficiente a atitude } \\
\text { da Abrale. "Mas só em último caso." }\end{array}$ \\
\hline & MEC & $\begin{array}{l}5^{\circ} \S \text { : Sobre a possibilidade de a avaliação se transformar } \\
\text { num processo de certificação contínuo, o ministério } \\
\text { sustenta que isso implicaria "desatualizações } \\
\text { intransponíveis" para os alunos, "tendo em vista a } \\
\text { velocidade com que as informações circulam". }\end{array}$ \\
\hline
\end{tabular}


Logo no subtítulo do texto, temos uma declaração em discurso indireto em que não é citado seu autor. $\mathrm{O}$ ator social referente a esse enunciado só será revelado no $2^{\circ}$ subtítulo do texto. A voz é dos autores de livros didáticos que criticam a avaliação sem uma individualização.

Já no $1^{\circ}$ parágrafo do texto, temos o discurso indireto da voz do presidente da Abrale (Associação Brasileira dos Autores de Livros Educativos), o senhor Gelson Iezzi. A expressão "segundo ele" foi usada nos dois primeiros parágrafos. O modalizador "segundo" tem a função específica de enviar a um outro discurso. Dessa maneira, o enunciador se afasta da declaração preservando sua imagem pessoal.

$\mathrm{Na} 2^{\circ}$ linha do $2^{\circ}$ parágrafo, temos uma inserção do discurso direto dentro do discurso indireto, ainda com o mesmo ator social: o presidente da Abrale, nessa inserção o verbo introdutório de opinião, que se posiciona ao final do discurso direto, é o verbo "afirmar" que indica "posições oficiais e afirmações positivas", segundo Marcuschi (2007).

Tanto no discurso indireto do $3^{\circ}$ parágrafo, quanto no discurso direto do $4^{\circ}$ parágrafo, o verbo introdutório de opinião utilizado é o “defender" que, para Marcushi (2007), é usado como: “verbos indicadores de retomadas opositivas, organizadores dos aspectos conflituosos". O conflito no texto seria o questionamento sobre a forma com que são avaliados os livros didáticos.

No $6^{\circ}$ e no $7^{\circ}$ parágrafos aparece em discurso indireto outro ator social que é a Abrelivros (associação das editoras) que não corrobora com as idéias expostas pela Abrale e, na retranca intitulada "Experiência", cita outros problemas na avaliação dos livros, tendo como ator social a vice-presidente da instituição representante, Vera Duarte de Novais.

Como até esta parte do texto só foram revelados argumentos de quem questiona a qualidade da avaliação dos livros didáticos, temos a seção "Outro lado" em que é ouvida a outra parte interessada. No $1^{\circ}$ parágrafo surge a voz da secretária de Educação Fundamental do MEC, que diz já ter sido avaliada e negada pela justiça a reclamação feita por parte da Abrale. 
No $2^{\circ}$ parágrafo o ator social Nélio Bizzo, professor e coordenador da comissão que analisa os livros, "notifica extrajudicialmente" a Abrale por se sentir caluniado, tal expressão também tem um caráter de "retomadas opositivas, organizadores de aspectos conflituosos" (Marcuschi, 2007) como nos demais verbos utilizados anteriormente.

São vários os elementos linguísticos que comprovam o tom conflituoso que este texto possui. No $5^{\circ}$ parágrafo, o verbo "implicar" retoma um organizador de um momento argumentativo, mas uma argumentação pautada na oposição de vozes. Já no excerto localizado no $6^{\circ}$ parágrafo - "Em resposta à notificação encaminhada por Nélio Bizzo" - fica evidente a retomada do discurso anterior e a dialogicidade entre as parte.

No $7^{\circ}$ parágrafo, temos a introdução da voz da advogada de Bizzo, Beatriz de Abreu Dallari Guerreiro que tem como verbo introdutório de opinião, também, o verbo "afirmar". Como já foi dito antes, é pertencente a "posições oficiais e afirmações positivas" (Marcuschi, 2007), aqui no caso, a citação está ligada ao segundo tópico por se tratar de uma advogada e não pertencente ao governo.

Já no último parágrafo temos a retomada da voz de Bizzo em discurso indireto com a introdução do enunciado a partir de "para", modalizador cuja função é de enviar a um outro discurso.

Para Bizzo, os autores que criticam o processo estão "bravos" por terem sido rejeitados e precisarem devolver os direitos autorais antecipados pelas editoras- o que os autores negam. Ele diz que, embora não interfira diretamente no processo, analisa os pareceres da comissão de avaliação e nunca viu problemas que não estivessem bem justificados.

Temos, então, que Bizzo ironicamente fala da queixa dos autores dos livros didáticos estarem atreladas ao dinheiro. O enunciador usa a figura de Bizzo e desse enunciado, no fechamento do texto, demonstrando uma certa imparcialidade perante os fatos, dessa maneira sua opinião subjaz ao texto como sendo pró-avaliação. 
NOTÍCIA 25- 21/03/2006

\subsection{ESTUDANTES AINDA ESTÃO EM PRÉDIOS DE LATINHA}

\begin{tabular}{|l|l|l|}
\hline $\begin{array}{l}\text { Tipo de } \\
\text { discurso } \\
\text { empregado }\end{array}$ & $\begin{array}{l}\text { Ator social } \\
\text { atribuído ao } \\
\text { discurso }\end{array}$ & Reprodução do trecho \\
\hline $\begin{array}{l}\text { Discurso } \\
\text { indireto }\end{array}$ & $\begin{array}{l}\text { Secretaria da a } \\
\text { Secretaria } \\
\text { Municipal de } \\
\text { Educação }\end{array}$ & $\begin{array}{l}1^{\circ} \text { §: Segundo a Secretaria Municipal de Educação as escolas } \\
\text { que não estão prontas -Emei e Emef Parque das Flores e Emef } \\
\text { Jardim das Laranjeiras, na região de São Mateus-, além da Emef } \\
\text { Jardim Vila Nova, em Itaquera, serão entregues neste semestre. } \\
\text { A s disse que os pais dos alunos pediram que os estudantes só } \\
\text { saíssem das escolas de latinha quando os prédios de alvenaria } \\
\text { estivessem prontos. }\end{array}$ \\
\hline
\end{tabular}

OUTRO LADO

\begin{tabular}{|c|c|c|}
\hline $\begin{array}{l}\text { Tipo de } \\
\text { discurso } \\
\text { empregado }\end{array}$ & $\begin{array}{lr}\text { Ator } & \text { social } \\
\text { atribuído } & \text { ao } \\
\text { discurso } & \\
\end{array}$ & Reprodução do trecho \\
\hline \multirow[t]{3}{*}{$\begin{array}{l}\text { Discurso } \\
\text { indireto }\end{array}$} & $\begin{array}{lr}\text { Secretário } & \text { da } \\
\text { Educação } & \text { da } \\
\text { prefeitura, José } \\
\text { Aristodemo Pinotti }\end{array}$ & $\begin{array}{l}1^{\circ} \S: \text { O secretário da Educação da prefeitura, José } \\
\text { Aristodemo Pinotti, não comentou ontem a situação dos } \\
\text { alunos na escola. A coordenadoria de educação de } \\
\text { Itaquera, designada pela secretaria para comentar o } \\
\text { problema, afirmou que as condições mínimas para o } \\
\text { funcionamento da Emef estão atendidas }\end{array}$ \\
\hline & $\begin{array}{l}\text { Diretor da escola, } \\
\text { Francisco Calado }\end{array}$ & $\begin{array}{l}5^{\circ} \text { §: Ele afirmou que o tempo de duração da aula volta ao } \\
\text { normal amanhã e que haverá reposição do tempo perdido } \\
\text { no período -as aulas começaram no local na metade de } \\
\text { fevereiro. }\end{array}$ \\
\hline & $\begin{array}{l}\text { Coordenadora } \\
\text { Elizabete dos } \\
\text { Santos Manastarla }\end{array}$ & $\begin{array}{l}7^{\circ} \text { e } 8^{\circ} \text { §: Sobre a falta de área de lazer, a coordenadora } \\
\text { disse que a escola poderá usar mais os equipamentos ao } \\
\text { seu redor -tanto escolas como CEUs e o Sesc. } \\
\text { A coordenadora disse que a Emef tem saída de emergência, } \\
\text { mas que não foi mostrada aos alunos para eles não } \\
\text { brincarem no local. "Os professores sabem." Há previsão } \\
\text { também de reforma de banheiros no local. }\end{array}$ \\
\hline $\begin{array}{l}\text { Discurso } \\
\text { indireto } \\
\text { seguido } \\
\text { direto }\end{array}$ & $\begin{array}{l}\text { Coordenadora } \\
\text { Elizabete dos } \\
\text { Santos Manastarla }\end{array}$ & $\begin{array}{l}2^{\circ} \S: \text { Mesmo sendo de alvenaria, cada classe tem um } \\
\text { ventilador. "A escola de latinha era muito pior", disse a } \\
\text { coordenadora Elizabete dos Santos Manastarla. } \\
3^{\circ} \S \text { : Apesar de declarar que isso seja suficiente, } \\
\text { Manastarla afirmou que hoje cada classe ganhará mais uma } \\
\text { peça. "Não é porque você [a reportagem] está aqui. } \\
\text { Tínhamos pedido isso no último dia } 3 \text {. A compra já está } \\
\text { empenhada", disse -a nota com o empenho (último passo } \\
\text { burocrático antes da compra) tinha data de ontem. }\end{array}$ \\
\hline
\end{tabular}




\begin{tabular}{|l|l|l|}
\hline $\begin{array}{l}\text { Discurso } \\
\text { indireto } \\
\text { seguido } \\
\text { direto }\end{array}$ & $\begin{array}{l}\text { Diretor da escola, } \\
\text { Francisco Calado }\end{array}$ & $\begin{array}{l}4^{\text {o }} \text { §: Com relação à redução do tempo das aulas, o diretor } \\
\text { da escola, Francisco Calado, disse que tomou tal decisão } \\
\text { para que os alunos não andassem "no sol a pino". No } \\
\text { período da tarde, os alunos costumavam entrar às 13h e } \\
\text { passaram a entrar às 14h. "Além disso, como o trajeto da } \\
\text { outra escola [de latinha] até aqui é longo, de cerca de 1,2 } \\
\text { km, quis dar um tempo para as crianças se adaptarem", } \\
\text { disse. "Pensei neles. Não sabia que havia reclamações." } \\
6^{\circ} \text { § Sobre o forno da padaria, o diretor disse que ele é } \\
\text { elétrico e não causa calor excessivo nas salas. "Só fica um } \\
\text { cheiro de pão. Talvez isso confunda." }\end{array}$ \\
\hline
\end{tabular}

Neste texto, podemos perceber um diferencial diante dos outros textos da primeira década do século XXI, essa peculiaridade se dá pelo tamanho da notícia principal que se compõe por um único e curto parágrafo. Um discurso indireto em que o ator social seria a "Secretaria Municipal de Educação".

No entanto, já a seção "Outro lado" é composta de oito parágrafos sendo que, dentre eles, três são realizados em discurso indireto e três em discurso direto. Nos outros textos aqui analisados, tal disparidade entre texto principal e a seção "Outro lado" não ocorreu, mesmo porque é de praxe que o texto principal seja maior que essa seção.

O subtítulo da seção já se inicia com um discurso direto que só é revelado seu ator social no corpo do texto no meio do $1^{\circ}$ parágrafo. Tal estratégia discursiva pode ter sido adotada para chamar a atenção do leitor diante da citação em discurso direto, a princípio sem uma autoria declarada. No início do primeiro parágrafo, temos o ator social oficial José Aristodemo Pinotti, secretário da Educação que se recusa a falar sobre o assunto.

Ao iniciar o texto com uma recusa de uma figura pertencente ao governo e a disparidade de parágrafos entre a notícia principal e a seção "Outro lado", já nos revela indícios de que o enunciador tende a tomar uma posição oposta ao governo quanto aos "prédios de latinha".

No $2^{\circ}$ parágrafo, aparece a coordenadora de educação de Itaquera: Elizabete dos Santos Manastarla. Seu discurso direto é curto e o enunciador se utiliza desse discurso, não só para se afastar de tal declaração, mas também para ironizar, de certa forma, a fala da coordenadora. Haja vista que logo no $3^{\circ}$ parágrafo a inclinação do enunciador se 
torna explícita, há um “desmascaramento” diante do que é dito por ela e o fatos, ou seja, a data da solicitação de compra, pois segundo o excerto que segue:

\begin{abstract}
Apesar de declarar que isso seja suficiente, Manastarla afirmou que hoje cada classe ganhará mais uma peça. "Não é porque você [a reportagem] está aqui. Tínhamos pedido isso no último dia 3. A compra já está empenhada", disse-a nota com o empenho (último passo burocrático antes da compra) tinha data de ontem.
\end{abstract}

Dessa maneira, a FSP se mostra como um jornal detentor de poder e com capacidade de transformar a sociedade perante as suas intervenções. No $4^{\circ}$ parágrafo, o ator social que aparece é o do diretor da escola, Francisco Calado que se manifesta em discurso direto com a função de eximir o enunciador de qualquer declaração realizada por outrem.

O verbo introdutório de opinião usado para a coordenadora Elizabete dos Santos Manastarla e para o diretor da escola, Francisco Calado foi "afirmou" que indica, segundo Marcuschi (2007), "verbos indicadores de posições oficiais e afirmações positivas". Nesse caso, podemos perceber que o verbo foi utilizado mais no sentido de afirmações positivas, pois apesar de a coordenadora e de o diretor serem funcionários públicos, eles não gozam de um cargo elevado na Secretaria de Educação.

O modalizador "segundo" foi utilizado para a "Secretaria Municipal de Educação", dentro desse ator social não foi individualizado nenhum sujeito, ficando assim a palavra a cargo da Secretaria da Educação como um todo, como uma personificação da secretaria.

Já o ator social secretário da Educação da prefeitura, José Aristodemo Pinotti, tem como verbo introdutório de opinião o verbo "comentar" precedido de negação: "não comentou" que, segundo Marcuschi (2007), seria um "verbo indicador de retomadas opositivas, organizadores dos aspectos conflituosos". No entanto, a negação faz com que o conflito se instaure, pois ao negar qualquer comentário sobre as escolas de latinha o secretário compromete a sua imagem perante o leitor. 
NOTÍCIA 26- 5/03/2007

NENHUMA ESCOLA ESTADUAL NA CIDADE DE SP OBTEVE NOTA AZUL

\begin{tabular}{|c|c|c|}
\hline $\begin{array}{l}\text { Tipo de } \\
\text { discurso } \\
\text { empregado }\end{array}$ & $\begin{array}{lr}\text { Ator } & \text { social } \\
\text { atribuído } & \text { ao } \\
\text { discurso } & \end{array}$ & Reprodução do trecho \\
\hline \multirow[t]{2}{*}{$\begin{array}{l}\text { Discurso } \\
\text { indireto }\end{array}$} & $\begin{array}{lr}\text { A diretora } & \text { da } \\
\text { Faculdade } & \text { de } \\
\text { Educação } & \text { da } \\
\text { USP, } & \text { Sonia } \\
\text { Penin } & \end{array}$ & $\begin{array}{l}1^{\circ} \text { §: Segundo a diretora da Faculdade de Educação da USP, } \\
\text { Sonia Penin, pode-se falar em metodologia, fatores } \\
\text { pedagógicos, proximidade da escola de equipamentos } \\
\text { culturais, qualificação do professor ou outras tantas variáveis, } \\
\text { mas, para ela, o fator mais importante a determinar o fiasco } \\
\text { das públicas é o número de horas de estudo. } \\
3^{\circ} \text { §: A desvantagem do estudante da rede estadual cresce mais } \\
\text { se considerada a praga do absenteísmo dos professores, um } \\
\text { "problema impressionante", segundo Penin. }\end{array}$ \\
\hline & $\begin{array}{l}\text { Prof }^{\circ} \text {. Demerval } \\
\text { Saviani, } \\
\text { UNICAMP }\end{array}$ & $\begin{array}{l}4^{\circ} \S: \text { O professor Demerval Saviani, da Faculdade de } \\
\text { Educação da Universidade Estadual de Campinas, acredita que } \\
\text { uma explicação possível para o resultado pífio das estaduais } \\
\text { esteja no que chamou de "inclusão excludente", gerada pela } \\
\text { "progressão continuada". } \\
6^{\circ} \text { §: Ele explica: até } 1998,98 \% \text { dos alunos tinham acesso ao } \\
\text { ensino fundamental. Mas pouco mais da metade conseguia } \\
\text { formar-se na } 8^{\text {a }} \text { série. No início dos anos } 90 \text {, cerca de } 1,5 \\
\text { milhão de alunos eram expulsos ou fracassavam na escola por } \\
\text { ano. }\end{array}$ \\
\hline \multirow[t]{2}{*}{$\begin{array}{l}\text { Discurso } \\
\text { direto }\end{array}$} & $\begin{array}{lr}\text { A diretora } & \text { da } \\
\text { Faculdade } & \text { de } \\
\text { Educação } & \text { da } \\
\text { USP, } & \text { Sonia } \\
\text { Penin } & \end{array}$ & $\begin{array}{l}2^{\text {o }} \text { §: "A exposição do aluno ao estudo e à cultura, } \\
\text { consubstanciada na carga horária é o nó mais evidente do } \\
\text { ensino público", afirma. }\end{array}$ \\
\hline & $\begin{array}{l}\text { Prof }^{\circ} . \text { Demerval } \\
\text { Saviani, } \\
\text { UNICAMP }\end{array}$ & $\begin{array}{l}5^{\circ} \S: \text { "Incluiu-se o aluno na escola, sem dar a ele o domínio de } \\
\text { conteúdos elementares. "Segundo Saviani, "houve um esforço } \\
\text { para melhorar as estatísticas, e não o ensino". } \\
7^{\circ} \text { e } 8^{\circ} \S \text { : Saviani, que não é contrário à "progressão } \\
\text { continuada", diz, porém, que o que se fez "foi tentar resolver o } \\
\text { drama da evasão e da repetência com uma canetada, sem dotar } \\
\text { a escola de instrumentos para garantir que o aluno com } \\
\text { dificuldade pudesse resolver esse atraso, com aulas de reforço, } \\
\text { por exemplo". } \\
\text { "Implantada em 1997, o resultado da progressão continuada é } \\
\text { o que está aí: alunos saem da } 8^{a} \text { série mal sabendo ler e } \\
\text { escrever e entram no ensino médio sem condições de } \\
\text { acompanhar as aulas por absoluta falta de conhecimentos } \\
\text { básicos. Pior do que as notas do Enem despencarem, é ver que } \\
\text { a falta de investimento na educação está mantendo a maioria } \\
\text { da juventude excluída da atual sociedade do conhecimento", } \\
\text { diz. }\end{array}$ \\
\hline
\end{tabular}

Na notícia 26, o primeiro ator social que aparece é a diretora da Faculdade de Educação da USP, Sonia Penin. Apesar de ser pertencente a um cargo oficial direto do governo, tal ator tem um grande prestígio diante da sociedade paulistana, pois a USP é 
considerada uma das melhores universidade da América Latina, por isso o uso do modalizador "segundo" e da expressão "mas para ela" envia o discurso para a diretora, pois a ela é concedido direito a voz e supõe-se que tenha propriedade para dissertar sobre as notas baixas das escolas estaduais em São Paulo, o verbo "afirma" usado no $2^{\circ}$ parágrafo em discurso direto demonstra "posições oficiais e afirmações positivas", segundo Marcuschi (2007), o que corrobora com o fato desse ator social gozar de um grande prestígio diante da sociedade paulistana.

Já na retranca intitulada "Inclusão excludente", o ator social que aparece para embasar os argumentos do enunciador é Demerval Saviani, professor de Educação da Universidade Estadual de Campinas. Temos no $4^{\circ}$ parágrafo um discurso indireto, entremeado por pequenas expressões em discurso direto (entre aspas), em que o verbo introdutório de opinião usado foi "acredita" que, segundo Marcuschi (2007), estaria ligado a "verbos indicadores da provisioriedade de argumentos".

Logo no $5^{\circ}$ parágrafo temos um discurso direto intercalado por "segundo Saviani" e que registra quem é o autor e a quem pertence o discurso proferido. O professor se mostra conhecedor da polêmica, tanto que no $6^{\circ}$ parágrafo é usado outro "verbo indicador da provisioriedade de argumento"; o verbo "explicar" que revela o quanto o sujeito do enunciado é detentor de conhecimento perante seu enunciatário, mostrando-se de certa maneira, superior no assunto.

Podemos perceber que o professor Saviani teve mais espaço na notícia do que a diretora da Faculdade de Educação da USP, apesar de os dois serem funcionários públicos e questionarem a metodologia do ensino público. Dessa forma não houve contraposição de vozes na medida em que os dois atores sociais presentes se mostram contra a forma como o ensino se realiza nos últimos anos, principalmente a "progressão continuada", segundo o professor Saviani. 


\section{NOTÍCIA 27- 4/04/2007}

\section{MEC EXIGIRÁ QUE PROFESSOR SEJA AVALIADO}

\begin{tabular}{|c|c|c|}
\hline $\begin{array}{l}\text { Tipo de } \\
\text { discurso } \\
\text { empregado }\end{array}$ & $\begin{array}{lr}\text { Ator } & \text { social } \\
\text { atribuído } & \text { ao } \\
\text { discurso } & \\
\end{array}$ & Reprodução do trecho \\
\hline $\begin{array}{l}\text { Discurso } \\
\text { indireto }\end{array}$ & $\begin{array}{l}\text { Ministro Fernando } \\
\text { Haddad }\end{array}$ & $\begin{array}{l}3^{\circ} \S \text { : Ao apresentar o plano a educadores há duas semanas, } \\
\text { o ministro Fernando Haddad disse que teria disponível até } \\
\mathrm{R} \$ 1 \text { bilhão para investir nos municípios com piores } \\
\text { indicadores. Uma equipe técnica também visitaria os } \\
\text { municípios. }\end{array}$ \\
\hline \multirow[t]{2}{*}{$\begin{array}{l}\text { Discurso } \\
\text { indireto } \\
\text { seguido de } \\
\text { direto }\end{array}$} & $\begin{array}{l}\text { Diretor da CNTE } \\
\text { Denilson Bento da } \\
\text { Costa. }\end{array}$ & $\begin{array}{l}4^{\circ} \text { §: A proposta de exigir uma avaliação dos professores } \\
\text { foi bem aceita por representantes dos docentes e gestores. } \\
\text { "Não somos contrários à avaliação. A questão é saber } \\
\text { como ela será feita", afirmou o diretor da CNTE } \\
\text { (Confederação Nacional dos Trabalhadores em Educação) } \\
\text { Denilson Bento da Costa. "O perigo é que não haja } \\
\text { critérios claros, e o poder fique nas mãos dos diretores. }\end{array}$ \\
\hline & $\begin{array}{ll}\text { Presidente } & \mathrm{da} \\
\text { Undime, Maria } & \text { do } \\
\text { Pilar } & \end{array}$ & $\begin{array}{l}5^{\circ} \S \text { : Professores podem ser retaliados injustamente."Para } \\
\text { a presidente da Undime (entidade que reúne os secretários } \\
\text { municipais de Educação), Maria do Pilar, "não há nada } \\
\text { mais desestimulador para um professor aplicado ganhar o } \\
\text { mesmo que outro desinteressado, que falta a toda hora". }\end{array}$ \\
\hline $\begin{array}{l}\text { Discurso } \\
\text { indireto } \\
\text { entrecortado } \\
\text { por direto }\end{array}$ & $\begin{array}{l}\text { Presidente do } \\
\text { Consed, Maria } \\
\text { Auxiliadora Seabra } \\
\text { Rezende e Ministro } \\
\text { Fernando Haddad }\end{array}$ & $\begin{array}{l}\text { 60§: Já a presidente do Consed (conselho que reúne os } \\
\text { secretários estaduais), Maria Auxiliadora Seabra Rezende, } \\
\text { afirma que o desafio é "criar uma avaliação justa, que não } \\
\text { seja punitiva nem meramente cartorial". Ontem, Haddad } \\
\text { afirmou que serão contratados } 80 \text { técnicos-consultores da } \\
\text { Unesco, que serão "um braço do MEC nos municípios } \\
\text { com mais dificuldades". De acordo com ele, o Ideb jáa } \\
\text { identificou os mil municípios mais debilitados e os } 200 \\
\text { com melhor situação. }\end{array}$ \\
\hline
\end{tabular}

No $1^{\circ}$ parágrafo dessa notícia temos a personificação de um decreto e o verbo "exigir" como introdutório de opinião desse documento, este é um verbo forte que mostra um ator social com grande prestígio social e poder. Tal decreto tem citações em discurso direto nos dois primeiros parágrafos que mostramos a seguir: "privilegiar o mérito, a formação e o desempenho", "valorizar o mérito", "dedicação, assiduidade, pontualidade, responsabilidade, realização de projetos e trabalhos especializados, curso de atualização e desenvolvimento profissional".

No $3^{\circ}$ parágrafo aparece a figura do ministro da Educação, Fernando Haddad em discurso indireto. É interessante notar que o enunciador usa a expressão verbal "disse que teria" no futuro do pretérito, mas poderia ter usado o pretérito perfeito ou até mesmo o presente do indicativo para falar sobre o dinheiro prometido por Haddad, mas 
o enunciador não o faz talvez, para se mostrar distante da afirmação e não tomar para si maiores consequências caso esse dinheiro não surja para a implantação do plano educacional.

Na retranca intitulada "Apoio", temos o ator social Denilson Bento da Costa, diretor da CENT (Confederação Nacional dos Trabalhadores em Educação) e o verbo introdutório de opinião usado para ele, para Maria Auxiliadora Seabra Rezende e para o ministro da Educação foi o "afirmar" que, segundo Marcuschi (2007), indica "posições oficiais e afirmações positivas". Para Haddad também foi usada uma expressão modalizadora "de acordo com ele", quem tem a função de enviar o discurso a outro.

O que fica claro neste texto é que o verbo "afirmar" foi usado para a maioria dos atores sociais não fazendo distinção entre os cargos de alta patente como o ministro da educação e os presidentes de organização das classes trabalhadoras, tal fato pode ter ocorrido porque o enunciador quisesse se valer verbos introdutórios de opinião de modo indiscriminado como forma de transmitir, à primeira vista, certa neutralidade dentro do texto, mas o que vemos a partir das análises é que, mesmo que se almeje, a neutralidade é impossível, já que o jornalista não colocou nenhuma voz que se dissesse totalmente contra a avaliação de docentes com seus devidos argumentos. Portanto, fica claro que o enunciador tende a ser pró-governo e pró-avaliação de professores. 
NOTÍCIA 28- 29/04/2008

São Paulo, terça-feira, 29 de abril de 2008 FOLHA DE S.PALLO COtidíäO

\begin{tabular}{|c|c|}
\hline & Texto \\
\hline
\end{tabular}

Burocracia tira verba das piores escolas

Municípios mais pobres têm dificuldades em comprovar titularidade de terreno onde recursos serão aplicados, o que impede repasse

De 12 escolas consultadas, 10 não receberam ajuda; secretários de Educação pedem flexibilidade ao MEC, que admite problemas

Reginaldo Pereira - 23.ago.07/Agência A Tarde

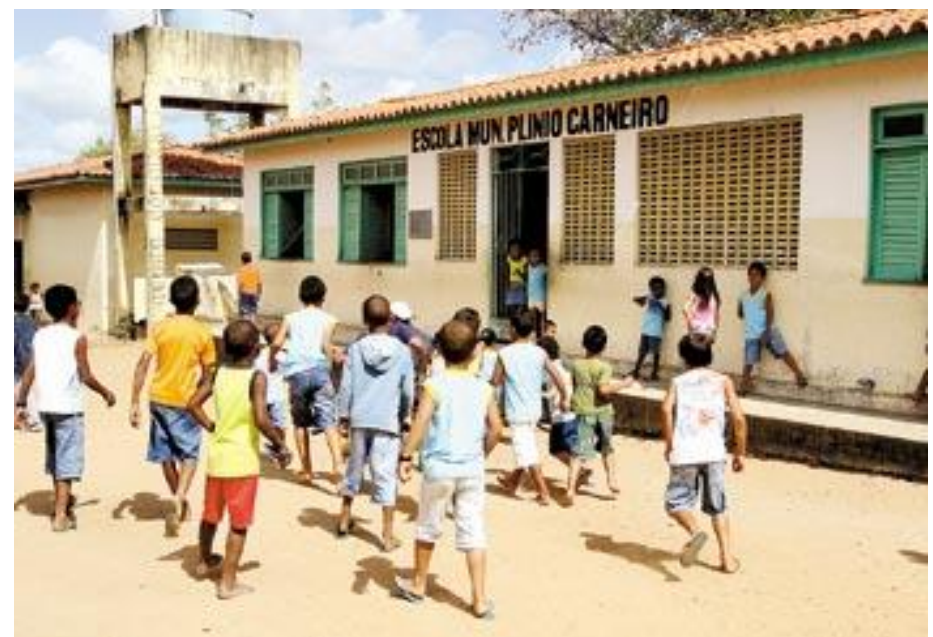

Alunos da primeira série do ensino fundamental na área externa da escola municipal Plínio Carneiro, na cidade de Biritinga $(B A)$

ANTÔNIO GOIS

DA SUCURSAL DO RIO

FÁBIO TAKAHASHI

DA REPORTAGEM LOCAL

Uma exigência burocrática tem impedido que recursos do governo federal cheguem às escolas com os piores indicadores educacionais do país.

O repasse de recursos aos municípios com mais dificuldades é considerado pelo próprio governo como uma de suas principais ações para melhorar a educação básica brasileira (da creche ao ensino médio). O problema ocorre porque o Tesouro Nacional exige que, para que haja transferência de verbas para construção, reforma ou ampliação da unidade, a prefeitura deve apresentar comprovação em cartório de titularidade do terreno onde serão investidos os recursos.

No entanto, são justamente os municípios mais pobres que têm relatado mais dificuldades em obter o registro principalmente aqueles em áreas rurais, indígenas ou quilombolas, onde dificilmente há documentação sobre a posse das terras.

A Folha conseguiu contato com 12 das 20 cidades com os piores indicadores educacionais do país, identificados pelo MEC como prioritários para receber ajuda técnica e financeira dentro do PDE (Plano de Desenvolvimento da Educação), lançado há um ano e que é o principal projeto do governo Lula na educação. Dez dessas cidades reclamaram da burocracia, que tem dificultado o recebimento dos recursos. Um exemplo é Aquibadã (SE), onde há só uma sala de leitura e uma quadra esportiva para as 27 escolas da cidade. A prefeitura pede verba para melhorar todas as unidades.

Já Dom Aquino (MT) busca verbas para a construção de uma escola, pois parte da rede municipal funciona de forma improvisada em salas que já chegaram a ser interditadas pelo sistema estadual, por serem vizinhas a uma delegacia.

O MEC admite o problema (leia mais nesta pág.), mas diz que nenhum recurso do PDE deixou de ser aplicado. A Secretaria do Tesouro Nacional diz que as exigências são feitas para evitar que um imóvel, depois da aplicação de verbas da União, seja reclamado pelo proprietário, prejudicando o atendimento à população. A presidente do Consed (conselho que representa os secretários estaduais de Educação), Maria Auxiliadora Seabra Rezende, diz que o problema burocrático é preocupante.

"Estamos pedindo mais flexibilidade ao governo. Um dos pontos mais críticos para os municípios mais pobres é 
justamente a construção ou reforma dos equipamentos escolares", afirma a presidente da Undime (entidade que

representa os secretários municipais de Educação), Justina Silva.

"A burocracia atrapalha. Faltou uma vírgula, o projeto volta", diz a secretária de Educação de Itaúba (MT), Ivanir

Cavalheiro Zonta -cidade com o segundo pior indicador do país.

Apesar das críticas com relação às verbas para infra-estrutura, todos os gestores elogiaram os demais pontos do

plano do governo, principalmente o auxílio técnico. " É um problema que temos de resolver, talvez com visita a

cada local", diz a secretária de Educação Básica do MEC, Maria do Pilar.

\begin{tabular}{|c|c|c|}
\hline $\begin{array}{l}\text { Tipo de } \\
\text { discurso } \\
\text { empregado }\end{array}$ & $\begin{array}{lr}\text { Ator } & \text { social } \\
\text { atribuído } & \text { ao } \\
\text { discurso } & \\
\end{array}$ & Reprodução do trecho \\
\hline \multirow[t]{2}{*}{ Discurso direto } & $\begin{array}{l}\text { Presidente } \text { da } \\
\text { Undime, Justina } \\
\text { Silva }\end{array}$ & $\begin{array}{l}8^{\circ} \S: \text { "Estamos pedindo mais flexibilidade ao governo. Um } \\
\text { dos pontos mais críticos para os municípios mais pobres é } \\
\text { justamente a construção ou reforma dos equipamentos } \\
\text { escolares", afirma a presidente da Undime (entidade que } \\
\text { representa os secretários municipais de Educação), Justina } \\
\text { Silva. }\end{array}$ \\
\hline & $\begin{array}{ll}\text { Secretária } & \text { de } \\
\text { Educação } & \text { de } \\
\text { Itaúba (MT) } & \end{array}$ & $\begin{array}{l}9^{\circ} \S: \text { "A burocracia atrapalha. Faltou uma vírgula, o } \\
\text { projeto volta", diz a secretária de Educação de Itaúba } \\
\text { (MT), Ivanir Cavalheiro Zonta - cidade com o segundo } \\
\text { pior indicador do país. }\end{array}$ \\
\hline $\begin{array}{l}\text { Discurso } \\
\text { indireto } \\
\text { seguido } \\
\text { direto }\end{array}$ & $\begin{array}{lr}\text { Secretária } & \text { da } \\
\text { Educação } & \text { Básica } \\
\text { do MEC. } & \end{array}$ & $\begin{array}{l}10^{\circ} \S \text { : Apesar das críticas com relação às verbas para } \\
\text { infra-estrutura, todos os gestores elogiaram os demais } \\
\text { pontos do plano do governo, principalmente o auxílio } \\
\text { técnico. "É um problema que temos de resolver, talvez } \\
\text { com visita a cada local", diz a secretária de Educação } \\
\text { Básica do MEC, Maria do Pilar. }\end{array}$ \\
\hline \multirow[t]{5}{*}{$\begin{array}{l}\text { Discurso } \\
\text { indireto }\end{array}$} & $\begin{array}{l}\text { Secretários } \\
\text { educação }\end{array}$ & $\begin{array}{l}\text { Subtítulo: De } 12 \text { escolas consultadas, } 10 \text { não receberam } \\
\text { ajuda; secretários de Educação pedem flexibilidade ao } \\
\text { MEC, que admite problemas. }\end{array}$ \\
\hline & $\begin{array}{l}\text { Cidades com os } \\
\text { piores indicadores } \\
\text { educacionais do } \\
\text { país }\end{array}$ & $\begin{array}{l}5^{\circ} \S: \text { Dez dessas cidades reclamaram da burocracia, que } \\
\text { tem dificultado o recebimento dos recursos. }\end{array}$ \\
\hline & $\begin{array}{l}\text { Ministério } \\
\text { Educação } \\
\text { Cultura }\end{array}$ & $\begin{array}{l}6^{\circ} \text { §: O MEC admite o problema (leia mais nesta pág.), } \\
\text { mas diz que nenhum recurso do PDE deixou de ser } \\
\text { aplicado. }\end{array}$ \\
\hline & $\begin{array}{l}\text { Secretaria do } \\
\text { Tesouro Nacional }\end{array}$ & $\begin{array}{l}6^{\circ} \text { §: A Secretaria do Tesouro Nacional diz que as } \\
\text { exigências são feitas para evitar que um imóvel, depois da } \\
\text { aplicação de verbas da União, seja reclamado pelo } \\
\text { proprietário, prejudicando o atendimento à população. }\end{array}$ \\
\hline & $\begin{array}{l}\text { Presidente } \\
\text { Consed }\end{array}$ & $\begin{array}{l}7^{\circ} \text { §: A presidente do Consed (conselho que representa os } \\
\text { secretários estaduais de Educação), Maria Auxiliadora } \\
\text { Seabra Rezende, diz que o problema burocrático é } \\
\text { preocupante. }\end{array}$ \\
\hline
\end{tabular}

No subtítulo: "De 12 escolas consultadas, 10 não receberam ajuda; secretários de Educação pedem flexibilidade ao MEC, que admite problemas" (grifo nosso), observamos que o verbo "admitir" é caracterizado pela reformulação ou retomadas opositivas. O discurso indireto é usado muitas vezes para uma espécie de tradução do 
discurso do outro, podendo ser pouco ou muito fiel ao seu pronunciamento. No caso desse subtítulo, o verbo é responsivo aos subtítulos anteriores. Além disso, está ligado à autoria de um órgão oficial do governo, o MEC (Ministério de Educação e Cultura), que possui prestígio oficial e social de grande respeitabilidade.

No enunciado "Dez dessas cidades reclamaram da burocracia, que tem dificultado o recebimento dos recursos" (grifo nosso), o jornalista utiliza uma figura de linguagem que é a metonímia, a parte pelo todo, a cidade pelos moradores, o que dá maior escopo ao texto, pois não se nominalizam as pessoas, mas, por outro lado, fragiliza, por não haver a caracterização efetiva de quem "reclama". Seriam os moradores? Os prefeitos? Os alunos? Os pais dos alunos?

Por sua vez, nos parágrafos:

O MEC admite o problema (leia mais nesta pág.), mas diz que nenhum recurso do PDE deixou de ser aplicado.

A Secretaria do Tesouro Nacional diz que as exigências são feitas para evitar que um imóvel, depois da aplicação de verbas da União, seja reclamado pelo proprietário, prejudicando o atendimento à população.

A presidente do Consed (conselho que representa os secretários estaduais de Educação), Maria Auxiliadora Seabra Rezende, diz que o problema burocrático é preocupante.(grifo nosso)

Temos um longo período de discurso indireto, o que demonstra um certo distanciamento do jornalista frente às declarações oficiais apresentadas. Além disso, verificamos que o verbo "dizer" aparece duas vezes. No caso do texto sob análise, tal verbo configura-se em sentenças afirmativas e está ligado a posições oficiais (Secretaria do Tesouro Nacional e a presidente do conselho que representa os secretários estaduais de Educação, Maria Auxiliadora Seabra Rezende).

Apesar das críticas com relação às verbas para infra-estrutura, todos os gestores elogiaram os demais pontos do plano do governo, principalmente o auxílio técnico, conforme observamos no trecho: "É um problema que temos de resolver, talvez com visita a cada local', diz a secretária de Educação Básica do MEC, Maria do Pilar" (grifo nosso).

O texto aqui analisado não se mostra com uma polifonia muito divergente, na medida em que, ao final do texto, o jornalista faz uso de vozes de autoridades municipais que requeriam recursos e reclamavam em relação à morosidade do 
recebimento desse montante; no entanto, os órgãos municipais admitem que o plano do governo seja bom. Desse modo, as vozes que no começo do texto eram opostas, no final confluem e misturam-se.

NOTÍCIA 29- 20/03/2009

PIORES ESCOLAS REDUZEM AULA POR FALTA DE ÁGUA

\begin{tabular}{|c|c|c|}
\hline $\begin{array}{l}\text { Tipo de } \\
\text { discurso } \\
\text { empregado }\end{array}$ & $\begin{array}{l}\text { Ator social } \\
\text { atribuído ao } \\
\text { discurso }\end{array}$ & Reprodução do trecho \\
\hline $\begin{array}{l}\text { Discurso } \\
\text { direto }\end{array}$ & $\begin{array}{l}\text { Dona de } \\
\text { casa }\end{array}$ & $\begin{array}{l}1^{\circ} \S: \text { "Transferi minha filha de escola neste ano", diz a dona de } \\
\text { casa Francisca Batista. Segundo ela, uma das professoras da filha } \\
\text { chegou a escrever carroça com dois "s". }\end{array}$ \\
\hline $\begin{array}{l}\text { Discurso } \\
\text { indireto } \\
\text { seguido } \\
\text { direto }\end{array}$ & $\begin{array}{l}\text { Luciana } \\
\text { Nunes, mãe } \\
\text { de aluna }\end{array}$ & $\begin{array}{l}2^{\circ} \S \text { : Nesta semana, houve uma reunião com pais e a nova } \\
\text { diretora. "Vamos ver no que dá agora", diz Luciane Nunes, mãe } \\
\text { de uma aluna. }\end{array}$ \\
\hline \multirow[t]{3}{*}{$\begin{array}{l}\text { Discurso } \\
\text { indireto }\end{array}$} & $\begin{array}{l}\text { Secretaria da } \\
\text { educação }\end{array}$ & $\begin{array}{l}3^{\circ} \text { §: Outro lado: Secretaria da Educação diz que novos banheiros } \\
\text { ficarão prontos na próxima semana e que irá chamar mais } \\
\text { professores para o local }\end{array}$ \\
\hline & $\begin{array}{l}\text { Pais de } \\
\text { alunos }\end{array}$ & $\begin{array}{l}1^{\circ} \text { §: Segundo os pais, o problema se arrasta desde } 2008 \text {, quando o } \\
\text { Idesp da escola caiu } 47,8 \% \text {. Os pais também se queixam da falta } \\
\text { de dedicação de professores. }\end{array}$ \\
\hline & $\begin{array}{l}\text { Secretaria da } \\
\text { educação }\end{array}$ & $\begin{array}{l}3^{\circ} \S: \text { O outro lado: A Secretaria da Educação admitiu os } \\
\text { problemas. Afirmou que a [escola] Dr. Genésio de Almeida } \\
\text { Moura tem quatro banheiros e que dois estão em reforma e ficarão } \\
\text { prontos na próxima semana. Os outros, da direção, podem ser } \\
\text { usados pelos alunos. Sobre o Professor Renato de Arruda } \\
\text { Penteado, a secretaria afirmou que o problema dos banheiros é a } \\
\text { falta d'água na região - informação contestada pelos moradores - e } \\
\text { que hoje irá mandar um caminhão- pipa para suprir a escola. } \\
\text { Sobre a falta de professores, a secretaria afirmou que há docentes, } \\
\text { mas que eles faltam e que irá chamar eventuais - que cobrem os } \\
\text { ausentes - a partir de segunda-feira. }\end{array}$ \\
\hline
\end{tabular}

Primeiramente, observamos que, no trecho: "As duas escolas ficam no mesmo lugar: a Vila Brasilândia (zona norte), distrito que recebeu a pior avaliação dos moradores no caderno DNA Paulistano, publicado pela Folha em 2008" (grifo nosso), novamente a FSP se auto-intitula como voz de autoridade. A FSP parece se autoconsiderar uma voz de credibilidade e confiança de fatos acontecidos, o que pode demonstrar também uma estratégia argumentativa e de marketing do próprio jornal. Isso se confirma no antepenúltimo parágrafo da notícia aqui analisada, em que o enunciador cita novamente o jornal como fonte averiguadora dos fatos degradantes que ocorreram 
na escola: "A Folha entrou ontem na escola e viu três banheiros interditados. Na saída, um aluno pediu para usar um deles e uma funcionária disse que não poderia" (grifo nosso).

Por sua vez, nos parágrafos:

\begin{abstract}
...É ali onde também fica a escola Deputado Luiz Sergio Claudino dos Santos, instituição de $1^{\mathrm{a}}$ a $4^{\mathrm{a}}$ série que mais piorou, segundo o Idesp (instrumento de avaliação das escolas estaduais criado em 2007), divulgado anteontem. Na pior escola de $1^{\mathrm{a}}$ a $4^{\mathrm{a}}$ série, a Dr. Genésio de Almeida Moura, que teve 1,08 no Idesp - o máximo é dez -, a situação relatada por alunos e pais é crítica: ratos no local, pombos no refeitório e uso de drogas."
\end{abstract}

Segundo os pais, o problema se arrasta desde 2008, quando o Idesp da escola caiu $47,8 \%$.

Os pais também se queixam da falta de dedicação de professores. "Transferi minha filha de escola neste ano", diz a dona de casa Francisca Batista. Segundo ela, uma das professoras da filha chegou a escrever carroça com dois "s". (grifo nosso)

Podemos verificar três vezes o uso da palavra "segundo", que é denominada por Grillo (2001) como modalização em segundo discurso. Para a pesquisadora, “expressões como 'segundo' e 'conforme' inscrevem-se em um paradigma de elementos modalizadores diversos, no interior dos quais sua especificidade é modalizar pelo envio a um outro discurso" (p.111). Esse procedimento do enunciador pode ser uma estratégia de afastamento da situação e de não se comprometer com tais declarações.

O verbo "queixar" mostra claramente a postura do jornalista frente a esses pais, tal verbo indica, segundo Marcuschi (2007), "emocionalidade circuntancial". Emocionalidade, de uma forma geral, não tem credibilidade para as pessoas. E, mesmo assim, o enunciador embute um verbo que demonstra subjetividade, dando a entender que os pais, talvez, não tenham argumentos sólidos, consistentes; por isso, o uso do verbo "queixar" em vez de, por exemplo, "reivindicar" ou "protestar", verbos mais fortes e que trazem um caráter menos subjetivo.

Ainda no trecho acima, verificamos que o enunciador também não se responsabiliza pela acusação feita à professora que escreveu carroça com dois "s", pois se utiliza de discurso direto e do modalizador "segundo" que envia o discurso para outro, eximindo-se de qualquer culpabilidade diante da declaração ser verdadeira ou não. Isso pode ter ocorrido devido ao fato de que a declaração é proveniente de uma dona de casa e não de uma pesquisa ou de uma voz de autoridade oficial. Isso nos leva a 
pensar que o motivo de o enunciador não ter tomado para si uma voz que, socialmente, não é de prestígio.

Na continuidade da notícia da FSP, no "Outro lado" - trecho no qual o jornal tenta mostrar a versão da outra parte que ainda não foi mencionada ou que foi refutada durante o corpo do texto principal - há um relato sobre a falta d'água e das condições de ensino de algumas escolas. Podemos perceber que o paratexto já leva para uma refutação dentro da própria estrutura do texto, de seu título, pois o jornalista assim inicia: "A Secretaria da Educação admitiu os problemas". "Admitir" pertence ao tipo de verbo indicador de retomadas opositivas, uma espécie de "organizador dos aspectos conflituosos”, segundo a classificação de Marcuschi (2007).

A notícia já vinha em um processo argumentativo crescente a favor dos alunos que estavam com dificuldades em assistir às aulas, e a seção "Outro lado" só corrobora com o que o governo tem a dizer diante desses problemas, conforme observamos no trecho:

(...) Afirmou que a [escola] Dr. Genésio de Almeida Moura tem quatro banheiros e que dois estão em reforma e ficarão prontos na próxima semana. Os outros, da direção, podem ser usados pelos alunos. Sobre o Professor Renato de Arruda Penteado, a secretaria afirmou que o problema dos banheiros é a falta d'água na região informação contestada pelos moradores - e que hoje irá mandar um caminhão- pipa para suprir a escola. Sobre a falta de professores, a secretaria afirmou que há docentes, mas que eles faltam e que irá chamar eventuais - que cobrem os ausentes - a partir de segunda-feira. (grifo nosso)

O verbo "afirmar" aparece três vezes, sempre ligado à secretaria de Educação. Segundo Marcuschi (2007), o verbo é do tipo que indica "posições oficiais e afirmações positivas", o que corrobora com o uso nesse texto também. Por sua vez, o verbo "contestar" está ligado aos moradores do bairro. A voz desse discurso é atribuída às pessoas que moram ali e vêem os problemas da comunidade. Tal verbo se enquadraria nos "Verbos indicadores de retomadas opositivas, organizadores dos aspectos conflituosos" (Marcuschi, 2007). Isso nos mostra que existe um conflito, uma luta de vozes entre as partes. 
NOTÍCIA 30- 26/03/2009

\section{SP PAGARÁ BÔNUS A 72\% DOS FUNCIONÁRIOS DA EDUCAÇÃO}

\begin{tabular}{|c|c|c|}
\hline $\begin{array}{l}\text { Tipo de } \\
\text { discurso } \\
\text { empregado }\end{array}$ & $\begin{array}{lr}\text { Ator } & \text { social } \\
\text { atribuído } & \text { ao } \\
\text { discurso } & \\
\end{array}$ & Reprodução do trecho \\
\hline \multirow[t]{2}{*}{$\begin{array}{l}\text { Discurso } \\
\text { direto }\end{array}$} & $\begin{array}{l}\text { Governador de } \\
\text { São Paulo, José } \\
\text { Serra (PSDB) }\end{array}$ & $\begin{array}{l}2^{\circ} \S: \text { "Foi uma regulamentação por parte da secretaria, que } \\
\text { decidiu, além dos bônus, também dar uma gratificação para } \\
\text { as } 10 \% \text { melhores. Tem escolas que estão no topo dos } 10 \% \text {, } \\
\text { então nós resolvemos também dar um prêmio para incentivar } \\
\text { que continuem por cima." }\end{array}$ \\
\hline & $\begin{array}{lr}\text { Secretária } & \text { da } \\
\text { educação, } & \text { Maria } \\
\text { Helena } & \end{array}$ & $\begin{array}{l}3^{\circ} \text { §: "É um modelo que premia o mérito, que premia a } \\
\text { evolução de cada escola. Cada escola deve melhorar em } \\
\text { relação ao seu ponto de partida, que foi dado em 2007", } \\
\text { afirmou a secretária Maria Helena. }\end{array}$ \\
\hline $\begin{array}{l}\text { Discurso } \\
\text { indireto } \\
\text { seguido } \\
\text { direto }\end{array}$ & $\begin{array}{lr}\text { Presidente } & \text { da } \\
\text { UDEMO, Luiz } \\
\text { Gonzaga de } \\
\text { Oliveira Pinto }\end{array}$ & $\begin{array}{l}4^{\circ} \S: \text { O valor menor é criticado pelo presidente da Udemo } \\
\text { (sindicato dos diretores das escolas estaduais), Luiz Gonzaga } \\
\text { de Oliveira Pinto. Ele diz discordar do critério e que as } \\
\text { escolas com índice elevado deveriam ter bônus máximo, } \\
\text { pois já realizam um "bom trabalho". Ele afirma ainda que, } \\
\text { "enquanto os salários do magistério não forem compatíveis, } \\
\text { o bônus será sempre um problema sério, não vai satisfazer a } \\
\text { ninguém." }\end{array}$ \\
\hline \multirow[t]{3}{*}{$\begin{array}{l}\text { Discurso } \\
\text { indireto }\end{array}$} & $\begin{array}{l}\text { Governo de São } \\
\text { Paulo }\end{array}$ & $\begin{array}{l}1^{\circ} \text { \&: O governo de São Paulo anunciou ontem que pagará } \\
\text { uma bonificação salarial para } 195,5 \text { mil dos } 270 \text { mil } \\
\text { servidores da rede estadual de ensino, entre eles } 131 \text { mil } \\
\text { professores, diretores e supervisores. }\end{array}$ \\
\hline & $\begin{array}{l}\text { Jornal Folha de S. } \\
\text { Paulo }\end{array}$ & $\begin{array}{l}2^{\circ} \S \text { : Como antecipado ontem pela Folha, a bonificação } \\
\text { contemplará também professores e servidores de escolas que } \\
\text { já têm bons indicadores de qualidade, mas que, pelo projeto } \\
\text { original, ficariam sem essa gratificação porque não } \\
\text { conseguiram melhorar o desempenho. Agora, todas as } \\
\text { escolas que ficaram entre as } 10 \% \text { melhores no Idesp } 2008 \\
\text { serão premiadas. }\end{array}$ \\
\hline & $\begin{array}{l}\text { Governador José } \\
\text { Serra e Secretária } \\
\text { da Educação }\end{array}$ & $\begin{array}{l}2^{\circ} \S: \text { Ao lado da secretária da Educação, Maria Helena } \\
\text { Guimarães de Castro, o governador José Serra (PSDB) } \\
\text { negou, ao divulgar o bônus, ter havido mudança de regras. }\end{array}$ \\
\hline
\end{tabular}

Com base nos critérios definidos por Marcuschi (2007), a respeito da ação dos verbos introdutores de opinião, verificamos que o verbo "anunciou”, em "O governo de São Paulo anunciou ontem que pagará uma bonificação salarial para 195,5 mil dos 270 mil servidores da rede estadual de ensino" (grifo nosso), pertence a um tipo de verbo que "indica posições oficiais e afirmações positivas". No caso, esse verbo está estritamente ligado a posições oficiais, pois, se não fosse a voz de uma autoridade pertencente ao Estado, órgão público, o verbo talvez fosse outro, como, por exemplo, “disse" que é considerado um verbo neutro pelo mesmo pesquisador. 
O verbo “dizer", segundo Marcuschi (2007), serve como um "coringa”, pois pode ser alocado, dependendo do contexto e do tipo de discurso, nos sete tipos de funções dos verbos introdutores de opinião, a saber: (i) indicadores de posições oficiais e afirmações positivas; (ii) indicadores de força do argumento; (iii) indicadores de emocionalidade circunstancial; (iv) indicadores de provisoriedade do argumento; (v) organizadores de um momento argumentativo no conjunto do discurso; (vi) indicadores de retomadas opositivas, organizadores dos aspectos conflituosos; (vii) interpretativos do caráter ilocutivo do discurso referido (p.163-164)

Já no segundo parágrafo:

Como antecipado ontem pela Folha, a bonificação contemplará também professores e servidores de escolas que já têm bons indicadores de qualidade, mas que, pelo projeto original, ficariam sem essa gratificação porque não conseguiram melhorar o desempenho. (grifo nosso)

O próprio jornal FSP é tomado como voz de autoridade a ser confiada e seguida. Isso é o que Grillo (2001) também reconheceu, ao pesquisar manuais de redação, tanto da FSP quanto de seu concorrente o jornal O Estado de S. Paulo. Os manuais de redação destes jornais se apresentam como se fossem fonte única e adequada de uso da Língua Portuguesa, na perspectiva do jornalismo e daquilo que a empresa quer de seus profissionais, deixando de lado a gramática normativa e as pesquisas lingüísticas. Isso demonstra a postura da FSP perante outros manuais e gramáticas. Assim, na visão da autora, nos manuais a língua portuguesa:

Esta (a língua portuguesa) é representada como um conjunto homogêneo e estável de formas na qual não há lugar para a variação, mas somente para desvios, vistos como corrupções que ameaçam a correção e a beleza da língua... Nem sequer é mencionada a existência do padrão culto escrito, como o fazem muitas gramáticas normativas quando se apresentam seus objetivos, uma vez que ele é visto como a única possibilidade da língua. (Grillo, 2005, p. 87).

No trecho: "Ao lado da secretária da Educação, Maria Helena Guimarães de Castro, o governador José Serra (PSDB) negou, ao divulgar o bônus, ter havido mudança de regras" (grifo nosso), o verbo "negou”, segundo Marcuschi (2007), pertence ao tipo de verbo "indicador de retomadas opositivas e organizador dos aspectos conflituosos". Em seguida, é utilizado o verbo "divulgar" que se enquadra no tipo de verbo "indicador de posição oficial ou afirmações positivas". Nesse caso, o 
verbo "divulgar" posterior ao verbo "negar" refuta a afirmação posterior. Já o verbo "divulgar", em si, denota uma estreita ligação com a posição oficial. A voz de dois atores sociais (da secretária da Educação, Maria Helena Guimarães de Castro, e do governador, José Serra) traz veracidade ao texto, o que corrobora para a tese de que tal verbo estaria condicionado ao relato de autoridades oficiais do governo, e não ao relato procedente de pessoas comuns.

No quarto parágrafo temos:

O valor menor é criticado pelo presidente da Udemo (sindicato dos diretores das escolas estaduais), Luiz Gonzaga de Oliveira Pinto. Ele diz discordar do critério e que as escolas com índice elevado deveriam ter bônus máximo, pois já realizam um "bom trabalho". Ele afirma ainda que, "enquanto os salários do magistério não forem compatíveis, o bônus será sempre um problema sério, não vai satisfazer a ninguém." (grifo nosso)

No excerto anterior apresenta-se uma citação em discurso direto precedida do verbo "afirmou". Tal verbo é positivo e refere-se à declaração de Maria Helena, secretária da Educação. Sendo ela ligada ao governo, a aplicação do verbo direciona-se, mais uma vez, à voz de uma autoridade social, no caso, uma representante do MEC.

A expressão "diz discordar” refere-se ao discurso de Luiz Gonzaga de Oliveira Pinto (presidente do Sindicato dos Diretores das Escolas Estaduais). O verbo “discordar" teria, segundo Marcuschi (2007), a função de "indicar retomadas opositivas para organizar aspectos conflituosos". Percebemos que nas inserções anteriores foram apresentadas vozes de autoridades oficiais do governo; contudo, para se referir a uma figura pública que não pertence ao governo, é utilizado o verbo “dizer”.

Ao final da notícia é apresentada uma única voz discordante sobre a validade e a efetiva funcionalidade do bônus para os funcionários da escola. O verbo "afirmar" apenas confirma a declaração anterior do presidente da UDEMO de que os salários já são baixos. Isso configura o uso da polifonia não apenas como introdução de discursos do outro, mas também com função construtora de argumentos no texto. 


\subsection{1 - Características marcantes no corpus na primeira década do século XXI}

(2000-2009)

É interessante notar que na primeira década do século XXI há grandes divergências e convergências de vozes e de atores sociais. Ao se tratar sobre as notícias relativas à educação há a inclusão de atores sociais das classes menos privilegiadas para que se tenha, dessa maneira, maior "democratização" nos textos jornalísticos, mas ao analisarmos mais profundamente estes textos, observamos que, na maioria das vezes, essas vozes são de uma certa forma negligenciadas.

Se por um lado há um maior uso de atores sociais, bem como o uso de vozes não-oficiais comparando com as décadas de 1940, 1940 e 1970, é fato também perceber que há uma homogeneização dos usos dos modalizadores que visam enviar a voz a um outro discurso, e também a regularização do uso dos verbos introdutórios de opinião. Tal fato pode ser explicado pela necessidade de o enunciador se mostrar imparcial.

Há que se levar em conta que em uma sociedade em que a informação se espalha quase que de forma imediata com o advento da internet, tudo o que se diz pode ser usado contra ou a favor da imprensa. Não estamos sob a ditadura ou militarismo como nas décadas anteriores; no entanto, nos vemos "presos" dentro de uma trama em que a liberdade de expressão tem seu cume máximo, mas todo DIREITO DE RESPOSTA deve ser do mesmo tamanho da notícia que caluniou um cidadão, por exemplo, no entanto, quase não vemos isso ocorrer de fato. Assim, o caos se faz no meio de algo que em certa medida se mostra livre e democrático. 


\section{CONSIDERAÇÕES FINAIS}

Ao final desta dissertação, cabem algumas considerações acerca do estudo realizado.

Primeiramente, o trabalho foi orientado a partir da Análise Crítica do Discurso, levando em consideração o contexto histórico de cada texto e o seu momento de produção, por isso se justifica o primeiro capítulo que contempla toda a história do Brasil, da imprensa, da FSP e por último da MRFSP.

Já no segundo capítulo, revelamos aspectos da argumentação e da polifonia para que no terceiro capítulo pudéssemos desvendar e analisar, de modo mais completo, as notícias do corpus. O tema educação foi observado no corpus selecionado tendo como ponto de partida o estudo da constituição da notícia, assim pudemos verificar como o gênero se estabelece e como ocorreram as transformações de discurso citado direto e indireto ao longo das décadas selecionadas.

Verificamos, pela análise do corpus, que houve algumas mudanças significativas, quanto à polifonia, como sintetizamos a seguir:

- É possível perceber um crescente uso da polifonia fazendo-se uma comparação contrastiva entre a década de 1930, 1940 com relação à década de 1970 e a primeira década do século XXI. Esse aumento se dá não apenas em números de discursos diretos e indiretos utilizados, mas também com relação aos atores atribuídos ao discurso.

- Se na década de 1930, 1940 e 1970 os discursos citados eram mais longos, em número de linhas, hoje temos discurso citados mais curtos e com diferentes atores sociais presentes, ou seja, diferentes vozes e pontos de vista que se contrapõem no desenrolar do texto.

- Além disso, se na década de 1930, 1940 e 1970 há o predomínio de vozes oficiais e tais vozes não eram diversificadas em relação à convergência e à divergência de opinião das vozes atribuídas, o que se vê na década atual é o grande uso de polifonia, seja ela de forma direta ou indireta. Sendo assim, os atores atribuídos a essas vozes são pertencentes a classes sociais distintas, e isso ocorre na maior parte das notícias atuais. 
Dessa maneira pudemos observar que o objetivo da imprensa na atualidade é mostrar os vários pontos de vista existentes na sociedade (seja do professor, aluno, secretário da educação, diretor, mãe de aluno) para que o leitor chegue à sua própria conclusão. No entanto, tal liberdade não é desprovida de ideologia e há sempre a opinião do enunciador, ainda que de modo implícito.

O que se pode questionar é a ordem e o espaço em que se insere a voz de uma autoridade oficial, já que não é o mesmo de uma voz desprovida de prestígio, como por exemplo, a voz de um aluno. Isso pode acarretar, mesmo que de modo velado, efeitos de sentidos divergentes em relação ao fato noticiado.

Outro ponto que foi levado em consideração nas análises são os "verbos introdutores de opinião" tratados por Marcushi (2007) a partir de uma tipologia e as suas respectivas funções que marcam, de certa forma, os discursos citados diretos e indiretos que surgem ao longo do texto.

$\mathrm{Na}$ análise feita a partir do corpus, pudemos perceber que a classificação I referente aos "verbos indicadores de posições oficias e afirmações positivas" são os mais usados em todas as décadas. É interessante notar que, se na década de 1930, 1940 e 1970 tais verbos estavam estritamente ligados atores sociais realmente pertencentes ao alto escalão do governo, já na primeira década do século XXI isso não ocorre, tais verbos são usados também como característicos de afirmações positivas relacionadas aos atores sociais comuns. Nas décadas anteriores podemos levar em consideração o fato de que no começo do século XX não existia a inserção de vozes das camadas menos privilegiadas da sociedade, portanto verbos de posições oficiais não poderiam ser atrelados à esses atores sociais.

Dessa forma podemos verificar que a voz só era concedida para os oficiais do governo e para grande elite de São Paulo, sendo a voz dos cidadãos englobada pelo enunciador, havendo um processo de apagamento e de não-legitimação dessas vozes. Segundo Van Leuween (1997), os imigrantes, muitas vezes deixados à margem da sociedade, tinham suas vozes "aglomeradas" em "associações" para os caracterizarem de uma forma discriminatória.

Finalmente, o que se quis mostrar neste trabalho foi a argumentação polifônica expressa através dos discursos citado direto e/ ou indireto existentes em notícias sobre 
avaliação educacional, buscando revelar seus caminhos argumentativos e seus efeitos de sentido. 


\section{REFERÊNCIAS BIBLIOGRÁFICAS}

AQUINO, Zilda Gaspar Oliveira de (1997). Conversação e conflito: um estudo das estratégias discursivas em interações polêmicas. São Paulo: Universidade de São Paulo/FFLCH, Tese de Doutoramento.

ARISTÓTELES. A retórica. Tradução Marcelo Silvano Madeira (Coleção Biblioteca Básica, 2007). São Paulo: Riddel.

BAKHTIN, Mikhail M. (2006) Estética da Criação Verbal. Trad.: Paulo Bezerra. São Paulo: Martins Fontes.

. (2002) Marxismo e Filosofia da Linguagem. São Paulo: Hucitec.

(1997) Problemas da poética de Dostoiévski. Rio de Janeiro: Forense Universitária.

BARROS FILHO, Clóvis e Pedro Lozano Bartolozzi (colaborador) (1995) Ética na comunicação da informação ao receptor. São Paulo: Moderna.

BATISTA. Paulo Eduardo (2009). O discurso do outro no jornalismo político digital. Dissertação de Mestrado. Paraíba: João Pessoa.

BENVENISTE (1991) Da subjetividade na linguagem. In: Problemas de Lingüística Geral I. São Paulo: Pontes.

BRANDÃO, Helena Nagamine (1994) Discurso e polêmica num debate político. Revista do Instituto de Estudos Brasileiros No 37. São Paulo: IEB, pp.129-143.

(1997) Discurso e modelos de identidade política. Cadernos da F.F.C. Análise do discurso. São Paulo: Universidade de São Paulo, pp.5971. 
(1998) Subjetividade, argumentação e polifonia. A propaganda da Petrobrás. São Paulo: Fundação Editora da UNESP: Imprensa Oficial do Estado.

(2002) Introdução à Analise do Discurso. Campinas:

Unicamp.

CARMAGNANI, Anna Maria Grammatico (1996) A argumentação e o discurso jornalístico: A questão da heterogeneidade em jornais ingleses e brasileiros. Tese de Doutoramento: São Paulo.

CITELLI, Adilson (1991) Linguagem e persuasão. São Paulo: Ática

ERBOLATO, Mário L. (2002) Técnicas de codificação em jornalismo: Redação, captação e edição no jornal diário. $5^{\circ}$ ed. São Paulo: Ática.

FAIRCLOUGH, Norman (2001) Discurso e mudança social. Brasília: Editora UnB.

FAUSTO, Boris (2009) História do Brasil. São Paulo: EDUSP

FOUCAULT, Michel (1996) A ordem do discurso. São Paulo: Loyola.

GRILLO, Sheila. V. C. (2001) Formas de produção na imprensa brasileira: greve dos petroleiros e gêneros do discurso nos jornais Folha de S. Paulo e o Estado de S. Paulo. Tese de doutoramento: São Paulo.

(2004) Discurso Alheio: Apreensão e Polifonia. In: SILVA, Luiz Antônio (Org.) A língua que falamos. São Paulo: Editora Globo, p.73-104. 
KOCH, Ingedore G. V. (1996) Argumentação e Linguagem. São Paulo: Cortez. (2001). O texto e a construção dos sentidos. São Paulo:

Contexto.

(2001). A inter-ação pela linguagem. São Paulo: Contexto.

(2009a). Argumentação e linguagem. São Paulo: Cortez.

(2009b). Introdução à lingüística textual. São Paulo: Martins

Fontes.

KUSCHNIR, Beatriz (2004). Cães de Guarda: Jornalistas e censores, do AI-5 à constituição de 1988. São Paulo: Boitempo.

LAGE, Nilson (1985) Linguagem Jornalística. São Paulo: Ática.

(1987) Estrutura da Notícia. 2a ed. São Paulo: Ática.

LEI DE IMPRENSA Lei $\mathrm{n}^{\circ}$ 5.250, de 9 de fevereiro de 1967 Atualizada até janeiro de 2000.Brasília (Disponível no site:http://www.camara.gov.br/internet/infdoc/Publicacoes /html/arquivospdf/leideimprensa.pdf no dia $13 / 07 / 2010$ às 13:00).

LIMA, Fábio Fernandes (2009). Metadiscursividade e persuasão em entrevistas com candidatos à Prefeitura de São Paulo. São Paulo: Universidade de São Paulo- FFLCH. Tese de doutoramento.

MAINGUENEAU, Dominique (1997) Novas Tendências em Análise do Discurso. Trad. De Freda Indursky. São Paulo: Pontes.

(2002) Análise de textos de comunicação. Trad. de

Cecília P. de Souza-e-Silva e Décio Rocha. São Paulo: Cortez. 
MANUAL DA REDAÇÃO: Folha de S. Paulo (2010). São Paulo: Publifolha.

MARCUSCHI, Luiz Antônio. (2002) Gêneros textuais: definição e funcionalidade. In: DIONÍSIO, Ângela P.; MACHADO, Anna Rachel; BEZERRA, Maria Auxiliadora (orgs.). Gêneros textuais \& ensino. Rio de Janeiro: Lucerna, p.19-36.

.(2007) A ação dos verbos introdutores de opinião. In:

Marcuschi, Luiz Antônio. Fenômenos da linguagem: reflexões semânticas e discursivas. Rio de Janeiro: Lucerna.

MELO, José M. (1979) Vantagens e desvantagens do jornalismo impresso. Petrópolis: Vozes.

(2003) Jornalismo Opinativo: gêneros opinativos no jornalismo brasileiro. Campos do Jordão: Mantiqueira.

NASCIMENTO, Erivaldo Pereira do (2006). A modalização no gênero notícia jornalística. In: Revista do GELNE- Grupo de Estudos Lingüísticos do Nordeste- Vol. 8Nos. 1/2- João Pessoa: Idéia.

(2009) Jogando com as vozes do outro: argumentação na notícia jornalística. João Pessoa: Editora Universitária da UFPB.

PASCHOAL, Engel (2007) A trajetória de Octavio Frias de Oliveira. São Paulo: Publifolha.

PERELMAN, Chaïm, OLBRECHTS-TYTECA (2005) Tratado da Argumentação: a nova retórica. São Paulo: Martins Fontes.

PIERUCCI, Antônio Flavio de Oliveira (2007) O Brasil Republicano,v.11: economia e cultura (1930-1964). Rio de Janeiro: Bertrand Brasil.

PINTO, Virgílio Noya (2003). Comunicação e cultura brasileira. São Paulo: Ática. 
PLATIN, Christian (2005) A Argumentação: História, teoria, perspectivas. São Paulo, Parábola.

RESENDE, Viviane de Melo e RAMALHO, Viviane (2006). Análise de Discurso Crítica. São Paulo: Contexto.

RIBEIRO, Alex (1995) Caso Escola Base- Os Abusos da Imprensa. São Paulo: Ática.

ROSSI, Clóvis (1994). O que é jornalismo. São Paulo: Brasiliense.

SERVA, Leão (2005). Jornalismo e desinformação. São Paulo: Editora Senac.

TRAVAGLIA, Luiz Carlos (2003). Gramática Ensino Plural. São Paulo: Cortez.

VAN DIJK, Teun A. (2008) Discurso e poder. São Paulo: Contexto. (1992) Cognição, discurso e interação. São Paulo: Contexto.

VAN LEEUWEN, Theo (1997) A representação dos actores sociais. In: PEDRO, Emília Ribeiro (org.) (1997) Análise Crítica do Discurso. Editorial Caminho, p. 162222. 
ANEXOS 


\section{Anexo I - Décadas de 1930 e 1940}

\section{Corpus referente às notícias publicadas na década de 30 e 40 do século $\mathrm{XX}$ pelo jornal Folha de S. Paulo}

\section{NOTÍCIA 1}

\section{Folha de S. Paulo 6/03/1931 \\ A ESCOLA DE ECONOMIA DOMESTICA AMPARA MOÇAS POBRES, TORNANDO-AS DONA DE CASA}

A obra philantropica da ligas das senhoras catholicas através de uma entrevista com a condessa Matarazzo

\section{Foto da escola}

Quem passa pela rua Alexandre Levvy, tem a sua attenção despertada por um vasto pavilhão de harmoniosas linhas arquithectonicas, situada no centro de um grande terreno. E' a escola de Economia Domestica, mantidas pela Liga das Senhoras Catholicas.

Esse estabelecimento que foi fundado para receber pensionistas internos contribuintes, no entanto, não se appareceram, vendo se a escola a fornecer pensão muito barata a senhoras e moças, para poder manter o estabelecimento, que, sob a direcção das Irmãezinhas da Immaculada Conceição, pela ordem, hygiene e conforto honra os foros da nossa Capital. Apezar dos escassos recursos, a Escola de Economia Domestica tem em actividade os cursos de culinária, costuras e bordados, confeitaria e levanderia.

Sobre essa importante instituição, procuramos ouvir a senhora condessa, Amalia Matarazzo, sua directora, que nos disse o seguinte:

“O projeto do prédio para a Escola só foi executado em parte. Foi construído um pavilhão. Outro igual aquelle se devia construir e mais uma capela que os uniria. Mas lutamos com muitas dificuldades e seremos, com certeza, forçadas a modificar o plano, construindo uns puchados ao pavilhão já prompto, sem nenhuma preoccupação da architectura. Gastando com o que tá feito 900 contos, em quanto andaria o projeto concluído?

Não temos alumnas internas contribuintes, fonte de renda com que contávamos. Do Governo, recebemos o anno passado não sabemos, se nos auxiliará. Promessa temos, e mais de uma.

Vive a Escola actualmente pela generosidade das famílias paulistanas com os productos dos trabalhos das alumnas.

As Escolas Domesticas na Europa gosam de muitos favores dos poderes públicos. Dão-lhe subvenção, instituem prêmios ou tomam a si o encargo de cobrir os "déficits". O interesse por ellas é grande e personalidades de destaque e que fazem entrega aos alumnos dos premios obtidos.

Infelizmente ainda não chegamos a essa situação invejável. Mas o tempo se incubirá de mostrar os frutos da nossa Escola, formando boas donas de casa e amparando com o trabalho moças inexperientes de quedas irreparáveis. Aos poucos se formará a convicção publica do valor da nossa instituição e então os auxílios se multiplicarão.

Tendo em vista a protecção que os ministérios da agricultura na Europa dispensam ás Escolas Domesticas, convidei o dr. Navarro de Andrade, para visitar a nossa Escola, terça-feira ultima.

Ficou o Secretario da Agricultura muito bem impressionado e prometteu-nos diversos adjuctorios. Assim a s. exa., vae franquear ás nossas alumnas para lactinicio do Posto Zootechinico. Fornece-lhe-ás conducçao para a útil aprendizagem. Incumbindo-se da contruçaõ do aviário ao qual doára os primeiros reprodutores. Prometteu-nos mudas para nossas secções de horticultura e jardinagem.

Estamos muito gratas ao Sr. Secretário da Agricultura.

Na nossa Escola vamos iniciar em breve no Ambulatorio a clinica infantil e o lactário, a cargo 
dos drs. José Toledo Junior e Eurico de Campos Abreu. Deverá auxilial-os uma educadora sanitária, que esperamos conseguir do Governo. Há muito que vimos solicitando uma educadora sanitária e uma professora. Não esmorecemos na insistência do pedido".

Antes de nos despedirmos da sra.Condessa Matarazzo, disse-nos ella :

"Faça o favor de noticiar pelo jornal que segunda-feira, 16, se iniciará na Escola, um curso de arte culinária, dirigido pelo chefe de cozinha do Automovel Clube, para sras. e moças de sociedade".

\section{NOTÍCIA 2}

$06 / 04 / 1931$

\section{O MAGISTÉRIO DE SÃO PAULO O CRITERIO PARA AS PROMOÇÕES}

\section{NA REUNIÃO HAVIDA HONTEM NO CENTRO DO PROFESSORADO TRATOU-SE DESTE ASSUMPTO.}

Conforme foi noticiado, realizou-se hontem á noite, na sede do Centro do Professorado Paulista, a reunião convocada especialmente para a discussão do critério das promoções no magisterio, a ser adoptado pelo Estado de São Paulo.

A's 20 horas, sob a presidência do professor Sud Menucci, secretariado pelos profs.: Odon Cavalcanti e Rachel Sampaio, com uma grande presença de associados, tiveram início os trabalhos.

A sessão, pôde-se dizer, foi inteiramente votada aos debates em torno do projeto apresentado pelo professor Cymbelino de Freitas.

Este projeto, sob todos os aspectos, agradou aos professores. Corresponde perfeitamente, a unaminidade dos applausos com que foi recebido, as aspirações do professorado paulista.Ell-o em suas linhas geraes:

$1^{\circ}$ - equiparação dos vencimentos de todos os professores primários quer estejam em exercício em escolas ruraes ou urbana, ou sejam, adjuntos de grupos escolares;

$2^{\circ}$ - divisão do Estado em três ou quatro "entrancias", para regular os respectivos accessos; $3^{\circ}$ estabelecimento do aumento periódico de vencimentos e que será, de $60 \$, 50 \$, 40 \$, 30 \$$ e $20 \$$, no fim de cada seis annos de effectivo exercício partindo de $500 \$$ mensaes no inicio da carreira, e finalizando com $700 \$$ aos trinta annos de magistério.

Dessa forma ficarão os professores distribuídos por seis classes, de acordo com a antiguidade, e terão seus vencimentos accrescidos, embora permaneçam durante muitos annos no mesmo cargo. Este é o meio mais efficaz de fixar o professor, até na zona rural, e impedir as contínuas remoções, motivadas pelo natural desejo de melhoria das condições pecuniárias.

Medidas semelhantes poderiam ser adoptadas, em relação aos diretores, fazendo desaparecer as desigualdades resultantes de funcionamento dos grupos escolares em dois ou mais períodos de aulas.

Para o critério objectivo a ser adoptado na classificação dos candidatos, há a considerar dois casos geraes:

$1^{\circ}$ ) de primeira nomeação, em se tratando de professor que ainda não exerceu o magistério. Serão tida da seguinte maneira:

$1^{\mathrm{a}}$ parcella- nota correspondente à antiguidade: multiplica-se à antiguidade: multiplica-se o numero de mezes de exercício por dez e divide-se por 36.

$2^{a}$ parcella - nota de esforço profissional: a porcentagem de promoções no anno anterior ao do 
concurso.

$3^{\text {a }}$ parcella - nota de cultura pedagógica: será uma nota de 0 a 100, dada em uma prova escripta, de trinta minutos de duração, sobre assumpto commum a todos os concorrentes.

O total dessas notas, dividido por 3 e approximado até centésimos, será a nota para a classificação dos candidatos.

Um exemplo concreto demonstrará a facilidade da applicação desse meio de accesso ao magistério, que afastará, por completo, a influência política a seleccionará as competências.

Assim, um professor com 12 annos e 6 mezes (por 150 mezes ) de exercício terá como nota de antiguidade- $41,669150 \times 10 \div 36=41,66$.

Se promover 2 de 5 alumnos dos 30 matriculados obterá a nota de promoção 83,33.

E se alcançou 92 pontos na prova escripta, completará o total 216,99, que dividido por 3 para a nota final, dá a classificação72,33.

Esse rápido concurso poderá realizar-se, uma vez por anno, na Capital, simultaneamente em duas ou três das mais importantes cidades do Estado. O que importa é que a these apresentada seja a mesma para com todos os candidatos. Quanto ao assumpto da prova scripta, poderá recahir no desenvolvimento de um plano de aula, designado na ocasião, ou ser constituído de uma série de "testes", semelhantes aos que há annos, se empregam, no Centro de Saúde Modelo, para a classificação dos professores que se candidatam ao curso de educadores sanitários.

\section{NOTÍCIA 3}

$18 / 04 / 1931$

AGgRAVANDO, EXCESSIVAMENTE, AS TAXAS DOS CURSOS SUPERIORES, O GOVERNO TRANCA SUAS ESCOLAS Á MOCIDADE QUE NÃO NASCEU EM BERÇO DE OURO"

A reforma do ensino provoca, no Rio de Janeiro, os mais veementes protestos dos estudantes.

RIO, 17 ( Da nossa succursal - pelo telefone) Está despertando grande commentarios nos meios estudantinos a reforma do ensino que acaba de ser publicada.

Os estudantes de medicina, como em todas as ocasiões precisas, promovendo reuniões, afim de ser orientada a acção da classe nos protestos a serem a serem feitos, contra certas irregularidades o, melhor, contra alguns absurdos que traz a nova reforma, com, por exemplo, a questão do pagamento de taxa e frequencia.

Com esse fim reuniu-se, hoje, a tarde no Instituto Anatomico, o directorio acadêmico da Faculdade de Medicina.

Nessa sessão ficou assentado que um delegado daquele directorio representaria a classe na da Federação que se realizaria,ainda hoje, na Escola de Bellas Artes.

Em virtude da situação em que se acham os estudantes de medicina, ouvimos vários rapazes sobre o assunpto e estes nos affirmaram que estavam ignorando tudo o que se passava e somente foram conhecedores do facto há dois dias, o queos deixou "groggy", ao saberem do tal augmento exaggeradissimo das taxas.

Em todo o caso, - accrescentaram-nos - que o pensamento dominante entre os demais collegas era promover-se uma acção uniforme da Federação Universitaria, de modo que os elementos universitários apparecessem em bloco, deante do governo. 
E terminando, para documentar o absurdo da majoração, exemplificaram:

- Os estudantes deverão agora pagar: $360 \$ 000$, no primeiro anno:.......490\$ooo, no segundo: $62^{\circ} \$ 000$, no terceiro: $830 \$ 000$, no quarto: $950 \$ 000$,no quinto,e $1: 840 \$ 000$, no sexto. Ora, até

Deante agora elles somente pagavam, $350 \$ 000$ em cada anno e $920 \$ 000$, no ultimo, por força, da defesa da these e do diploma.

Deante de tal exposição, nota-se, perfeitamente, que os estudantes de medicina estão cheios de razão para protestar contra esse absurdo. MEDICINA

A AGitAÇÃO NA POLYTECHNICA E A ATTITUdE DOS ESTUdANTES DE

RIO,17(H) - Conhecida que foi a nova reforma universitária, antehontem divulgada no "Diario Official"começaram a afitar-se as classes acadêmicas manifestando o seu desagrado principalmente na parte referente ás taxas que foram grandemente majoradas.

Na Escola Polychnica a agitação é grande, tanto que a congregação resolveu reuniu-se paratratar do caso, tende porém, a ultima hora, adiada a reunião.

Para tratar do assumpto reuniu-se, hoje, no Instituto Anatomico, o directorio acadêmico da Faculdade de Medicina.

A reunião era só do directorio. Entretanto, grande era a massa de estudantes que lá estavam, todos manifestando a sua decepção quanto á reforma, pelo augmento absurdo de taxas que consagra . Sentia-se logo que os estudantes de medicina sómente extranhavam e protestavam contra o novo regime de taxas.

Quando se ralizava a sessão soube-se que a congregação da Faculdadede Medicina tinha-se reunido e deliberado suspender as aulas até a completa applicação da reforma com a eleição do conselho techinico administativo indicado pelo novo director e regularização das matriculas.

O directorio resolveu protestar contra esses aumento de taxas. Ficou deliberado também eu se promover-se uma acção uniforme com a Federação Universitaria afim de levar o caso ao conhecimento do chefe do governo provisório.

\section{OS ACADEMICOS NO MINISTERIO DA EDUCAÇÃO}

RIO, 17(A.B) - Esteve no Ministerio da Educação, com Sr.Francico Campos, uma commissão da Federação Academica, composta de membros de todos os directorios existentes nos vários estabelecimentos de ensino superior.

Na ausência do ministro, os acadêmicos falaram ao Sr. Rodrigo de Melo Franco, secretario do Sr.Francisco de Campos. Referiram-se os jovens estudantes ao caso das taxas exigidas pela reforma do ensino, alegando que a situação em que vivem alguns acadêmicos, não lhes permitte pagar tão excessiva taxa. O Sr. Rodrigo de Mello Franco declarou, em nome do ministro, que este já havia resolvido, em parte, o caso, augmentando o numero de matriculas gratuitas e creando, mesmo o que elle denomonou "compromisso de honra", para os estudantes que não tenham recursos para iniciar ou continuar os estudos.

Esse compromisso é tomado pelo estudante com os estabelecimentos onde estejam estudando e por elle ficam obrigados a solver seus débitos logo que, formados, possam pagar á escola.

Ainda nessa reunião um dos membros do directorio da Polytechnica referiu-se á forma por que o ministro tratou aquelle estabelecimento.

O Sr. Rodrigo Mello Francisco deu, então, todas as explicações que lhe cabiam, affirmando, mesmo, que o Sr. Francisco Campos não tivera intuito de menosprezar esse estabelecimento, que é, sem duvida, dos mais dignos e onde o ensino é professado com a maior efficiencia e moralidade 


\section{COMO SE ORGANIZA, MODERNAMENTE, UM MINISTERIO}

A pasta da Educação e o seu serviço de publicidade

RIO, $17(\mathrm{H})$ - O Sr. Ministro da Educação approvou, hoje, uma portaria determinando que:

$1^{\circ}$ ) - o serviço de publicidade que compete á Directoria Geral de Informações, Estatistica e Divulgação se fará:

A (pelos annexos ao relatório annual do ministro;

b) pelo annuario estatístico da Educação e Saude Publica;

c) pelo boletim official do ministério, que será publicado trimestralmente:

d) pór opusculos avulsos dedicados a assumptos espectaes;

e) por meio de communicados semanaes á imprensa;

f) por pedido da Informações que forem dirigidos ou encaminhodos a repartição com relação aos assumptos superintendidos por este ministério.

$2^{\circ}$ ) - Todas as repartições e Instituições que compõem o ministério deverão contribuir para a efficiencia deste serviço, pela forma seguinte:

a)Collaborando com a Directoria de Informações. Estatistica e Divulgação, pelo modo que lhes for solicitado, no preparo e execução das pesquizas, estatísticas e inquéritos,outros que se houverem de effectuar e que tiverem correlação com os programmas:

b) fornecendo, subscriptos pelos respectivos directores ou pelos technicos que os mesmos designarem,artigos de collaboração para o boletim do ministério, ou monographias, de propaganda, informativas ou de finalidades educativas que devam ser publicadas avulsamente;

C) enviando, ate o dia 10 de cada trimestre, destinado ao boletim, um resenha das respectivas actividades no trimestre anterior, mas essas consideradas não na sua mera expressão burocrática e sim nos seus resultados práticos deordem technica ou acientifica, bem como as directrizes novas que se adoptarem na conformidade das exigências do serviço publico e das necessidades de aperfeiçoamento que se forem fazendo sentir:

d) prestando quaesquer informações ou contribuições requeridas pelo serviço de publicidade em apreço:

e) formulando sugestões e alvitres ditados pela ordem particular de factos e de estudos da competência de cada qual, afim de que o serviço de publicidade do ministério se vá aperfeiçoando progressivamente e, assim, corresponda cada vez melhor á finalidade.

$3^{\circ}$ )- O boletim do ministério cometerá essencialmente cinco secções, assim caracterizadas:a primeira destinada a constituir uma collectanea de artigos editoriaes ou de collaboração, veresando sobre o ponto de vista social, technico, administrativo ou scientifico, os assumptos incluídos no programma ministerial e contribuindo desse modo para a formação de correntes brasileiras de pensamento, focalizando os assumptos mais relevantes em matéria educacional e de assistência medico-sanitaria; a segunda dedicada á vulgarização dos dados estatísticos mais importantes, dentre os que a Directoria de Informações Estatistica e Divulgação fôr colligindo ou collaborando, acompanhados das anotações e commentarios que facilitem a interpretação delles ou lhes dêm relevo ou expressão; a terceira, contendo um desenvolvido noticiário sobre os factos mais relevantes occorridos no paiz ou fora delle, de repercussão necessária ou somente útil, já sobre a mentalidad brasileira em torno dos problemas de instrucção, hygiene, assistência hospitalar e assumptos correlatos; a quarta constituída por um promptuario das leis decretos e decisões referentes nos factores de acção governamental presididos pelo ministério; e a quinta resumindo os resultados práticos, scientificos e technicos, das actividades ministeriaes, nos variados desdobramentos e modalidades de que ella se revestem. 


\section{NOTÍCIA 4}

$18 / 03 / 1933$

COMO TEM SIDO RECEBIDO A BANDEIRA PAULISTA DE ALPHABETIZAÇÃO.

A PALAVRA DO DR. EURICO DE GÓES A RESPEITO - UMA INTERESSANTE CONFERENCIA.

Falando-nos a propósito da Bandeira Paulista de Alphabetização, o dr. Eurico de Goes teve as seguintes palavras:

- "Recebi a Bandeira de alma aberta, ou com toda a larga sympathia que merecem os nobres empreendimentos. A.B.P.A. está incontestavelmente nesse caso. Ensinar o povo a ler, alphabetizai-o, Instruil-o - é por, a primeira e a mais elevada missão dos governos e das nacionalidades. È como que fazer o sol inundar de luz uma floresta, antes mergulhada na sombra...

Tornam-se, naturalmente, melhor apparelhadas para a concorrência mundial as nações onde a instrucção popular é mais diffundida ou mais perfeita. Olhem-se os exemplos dos Estados Unidos, da Allemanha, da Inglaterra, da Suissa, etc.

Reconheço que o programma da Bandeira é devéras vasto e complexo. Será necessário desenvolver grande propaganda, grande energia organizada, grande continuidade de ação para conseguir os seus desideratos? Contribuição do povo, por si só? Talvez não baste! O extenso e variado programma das administrações publicas, não so do Estado, como dos municípios. Principalmente dos municípios.

D. Chiquinha Rodrigues, que é a alma ou uma das almas desse lindo movimento, e que já tem triumphado noutras tentativas congêneres, conseguirá verdadeiros milagres de realização, nesse horizonte ainda penumbroso e algo indefinido.

\section{QUANTO ÁS BIBLIOTHECAS}

- "O plano de idealização, ou de meios de execução, pertence mais a Bandeira do que a mim. Fui, segundo me informaram, apenas escolhido membro da commissão das bibliothecas municipaes ou populares. Darei de bom grado, o concurso que me for permitido prestar. Em chegando o momento, estou prompto a contribuir com a collaboração precisa.

Nada se faz sem a base econômica ou os fundos indispensáveis, em cada esphera de concretização utilitária.

Quando se reunirem os elementos de installação e custeio, quando for possível inaugurar a primeira bibliotheca popular, contem commigo. Os livros a serem escolhidos, para leitura publica ou para empréstimo a domicilio (não conheço ainda o projecto da Bandeira), constam da seleção feita no meu trabalho, meio inédito, sobre Formação das bibliothecas populares, em parte publicado na imprensa, há tempos. O mecanismo interno ou externo de funccionamento, as atribuições de empregados, a parte catalogal de fichários, não só de livros como de leitores ou candidatos a emprhaver reéstimos, se os houver, os requisitos de conservação, limpeza e immunização propylactica, etc.. - tudo isso decorrerá opportunamente.

Como, nas condições previsíveis, será impossível á Bandeira manter "bibliothecas em todos os municípios de Estado", julgo que o ideal será iniciar o tentamem dentro dos núcleos mais populosos, ou menos favorcidos no assumpto, prosseguindo gradativamente do centro para a peripheria. Evoco a mesma imagem do sol que irradia os seus raios em todas as direções...

Constituidas as bibliothecas populares, sob planos technicos e educativos, adaptáveis a cada ambiente de instrucção ou de cultura do povo, deverão após ser entregues às respectivas municipalidades, a cuja superitendencia ficarão pertencendo, de modo a haver regular fiscalização e manutenção garantidas". 


\section{CONFERENCIA PROMETIDA}

- "É verdade haver-me eu comprometido a effectuar uma conferencia, ou um recital em favor dos intuitos da Bandeira. Nesta época de crise não sei se elle renderá muito...

Seja como for, cumprirei prazeirosamente a minha palavra.

A these? Convem que interesse aos paulistas, antes de tudo. Que exalte a sua energia indomável, o seu poder de expansão, a sua grandeza racial, a sua gloria histórica. Que these poderá attrahir mais o patriotismo e o coração do que qualquer pagina rebrilhante, arrancada essa brônzea e áurea, a essa vibrantíssimae eterna epopéa das bandeiras.

Destacarei um dos episódios mais épicos e mais fulgurantes dessa gesta grandloquente, desse aventuroso romance das selvas e dos rios: Monções paulistas para Cuyabá. E lerei um dos trechos ou um poema do meu poema Os Sertanistas, ainda Inédito porém virtualmente ou literariamente já concluído: Monção de Rodrigo Cesar.

Farei rápida exposição oral ou de improviso (porque não me sobra tempo para escreve-la), sobre essas incursões históricas e lendárias dos bandeirantes, ou desses argonautas paulistas, que se aventuravam, em demorada viagem de mais de quinhentas léguas, através do sertão bravio das cachoeiras perigozas, dos Itororós arriscados e escachoantes, das tribus selvagens, atocaiadas num pontal de rio ou nas moitas dos tesos e das ilhas...

Resuscitarei esse inferno escaldante e pertllento da Malaria, até attingir a cidade longínqua do ouro, hoje" a Capital Verde", ou Cuyabá. Declamarei, por fim, desenvolvido episodio em versos, de rythmos variados em que se desenrola, como que geographica e cinematographicamente, a descripção de scenas locaes, vividas ou revividas por mim, no decurso das minhas alongadas viagens pelo nosso immensissimo e incomparável Brasil..."

\section{NOTÍCIA 5}

$06 / 03 / 1934$

HÁ FALTA DE ESCOLAS PRIMARIAS NA ALTA PAULISTA.

O grupo escolar de Marília funcciona num pardieiro de tabuas - Não há escola em Padre Nobrega -Em Oriente e Pompéa as escolas são em numero insulfficiente.

Não há muito, a Companhia Paulista de Estradas de Ferro fez inaugurar, solennemente, o seu novo trecho, compreendido entre Marilia e Pompeia. Desta capital partiram, além dos representantes dessa importante ferrovia, alguns membros do governo Armando de Salles Oliveira, visto como, após a solennidade, as autoridade procederam, em Marilia, ao lançamento da pedra fundamental dos serviços de águas e esgotos. Como após acontecer, completaram a comitiva diversos jornalistas, encarregados que foram de mandar, de lá, uma reportagem, embora rápida, dos acontecimentos.- sim, porque nessas occasiões há discursos de saudação, almoços, banquetas, bailles e muitas visitas são levadas a effeito.

\section{O GRUPO ESCOLAR DE MARÍLIA}

Marilia é uma grande cidade. Representa essa perola engastada em longínquas e verdejantes regiões paulistas um verdadeiro milagre, porquanto, contando apenas oito annos, possue já um commercio intensíssimo, industria muito desenvolvida, lavouras belíssimas, ruas bem cuidadas, praças, jardins, etc. Elegantes e soberbos edifícios emprestamas suas ruas e avenidas um aspecto deveras encantador, e o seu povo, hospitaleiro e bom, impressiona agradavelmente ao primeiro contacto. Ha, entretanto, qualquer coisa que muito desagrada a sua população; o prédio onde funciona o grupo escolar. Um pardieiro de madeira tosca, de feio aspecto, que não satisfaz. Innegavelmente, ás exigências e necessidades. Fala sobre o edificio do grupo escolar, dir-se-ia tocar numa ferida da população mariana; e não há, em Marilia, quem não se queixe desse estado de coisas no que diz respeito a instrucção publica. 
$\mathrm{Na}$ verdade, o desenvolvimento de Marília foi vertiginoso; talvez os dirigentes da municipalidade não tivessem tido tempo de mandar construir e offertar ao Estado um edifício em condições de melhor accomodar um estabelecimento de ensino desse gênero; contudo, o seu povo se queixa e terá, naturalmente, alguma razão para faze-lo.

\section{EM PADRE NOBREGA E ORIENTE}

Entre Marilia e Pompeia existem duas villas: Padre Nobrega e Oriente. Na primeira, a recepção proporcionada á comitiva official foi das mais enthusiasticas, Bandeirolas de variadas cores tremulavame, na estaçãozinha, muitas palmeiras crivavam á chegada do trem estrugiram palmas e orações calorosas.

O orador escolhido para saudar os representantes do governo paulista lembrou-se de pedir, com empenho, a criação de uma escolasinha para Padre Nobrega. A propósito, transcrevemos, aqui, as suas palavras: "Villa caçula, que nasceu florece no recanto mais rico e grandioso de Piratininga, não poderá ficar indifferente a este acontecimento. Satisfeita pôr ver realizado tão grande melhoramento, orgulhosa, por, embora de passagem, receber a visita das altas autoridades do Estado e da directoria da Companhia Paulista. Simples e humilde homenagem queremos prestar aqueles que, em tão pouco tempo, muito tem feito por S. Paulo: A'quelles que tem trabalhado desinteressadamente e no seu grande amor é puro patriotismo por esta florão querido, ainda vive e palpita o espírito dos que souberam lutar pela dignidade de São Paulo. A vós compete a responsabilidade de um porvir melhor. E para que isto aconteça é necessário que a bandeira da instrucção esteja hasteada em todos os pontos da terra paulista. E sabendo a quem nos dirigimos, ou não tenho pejo em mostrar este bando garrulo de crianças que, infelizmente são incapazes de vos saudar, cantando o Hymno Nacional! Senhores, nesta passagem tão rapidalança e os olhos para estas crianças immersas na treva da ignorância. Ajudas, eu vos peço em nome desta população, para que o mais depressa possivel tremule, como sempre gloriosa e invicta, na sacada de uma escola, a bandeira paulista"!

Novas palmas. Agradecimentos e o resfolegar da locomotiva anuncia que o trem vão partir, rumo a Oriente.

Outra recepção enthusiastica e muita criança na estação. Informações ao reporter. Adjantam que a população escolar de Oriente não é pequena e, no entanto, só possue uma escola isolada com 80 alumnos. De novo o trem se pôe em marcha, já agora com destino a Pompeia, termino dos trilhos da Companhia Paulista.

Pompeia é ainda districto e tem todas as características de uma cidade de futuro muito promissor. A sua população é de 2.200 almas; tem duas escolas isoladas estaduaes com 80 crianças, e cinco particulares, com 250. Em idade escolar possue Pompeia nada menos de 860 crianças, tanto assim que já foi endereçado pedido á Diretoria Geral do Ensino para a creação de um grupo com oito classes. Ali já havia crianças que já soubessem cantar, pois innumeras foram as que entoaram o Hynno da Artilharia em homenagem ao maior Arcy da Rocha Nobrega, que integrava a comitiva.

\section{NÃO É POSSIVEL FALAR-SE COM O DIRECTOR GERAL DO ENSINO}

Em Marilia novamente, os repórteres receberam de numerosos commerciantes e de varias pessoas da sociedade local as Incumbencia de pelos jornaes, falaram do triste estado do edifício do grupo escolar, afim de que o governo do Estado volte suas vistas para aquella região da Alta Paulista que trabalha e produz, sem receber os benefícios da assistência social.

Da nossa parte envidávamos todos os esforços para satisfazer o desejo dos marilenaria. Em uma reunião encontramo-nos com o prof. Luiz da Motta Mercier, director geral do Ensino, e, marcou-nos uma entrevista em seu gabinete de trabalho. Fomos pontuaes, mas o prof. Mercier não cumpriu o compromisso que comnosco assumira. Estivemos dois dias seguido na Diretoria Geral sem com tudo, logramos falar com o prof. Motta Mercier. No primeiro dia, fomos informados por um dos seus auxiliares, s. s. ido despachar com o secretário da Educação. No dia seguinte houve, evidentemente má vontade. Fomos annunciado ao prof. Motta Mercier e ficamos um tempo enorme á espera de que s. s. se dignasse nos receber, até que se esgotou a nossa paciência.

Assim, não nos foi possível obter informações sobre se a Directoria Geral pretende ou não dar 
escolas, que funcionam em prédios pelo menos decentes. A população escolar da Alta Paulista.

\section{NOTÍCIA 6}

$06 / 03 / 1934$

\section{A ORGANIZAÇÃO DA UNIVERSIDADE DE SÃO PAULO.}

O Sr. Secretario da Educação fala-nos sobre a marcha dos trabalhos - A Escola de Sciencias Economicas e a de Bellas Artes não farão parte este anno da Univesidade - Os professores já contratados na Europa pelo dr. Theodoro Ramos.

A Universidade de São Paulo, dentro em breve, será uma brilhante realidade.

As informações que o dr. Christiano Altenfelder, secretario de Educação, teve a gentileza de nos fornecer sobre a marcha dos trabalhadores da sua organização, são animadoras.

Possivelmente este mez - afirmou-nos s. exa. - será constituído o Conselho Universitário, de acôrdo com o determinado no artigo 28 do decreto que creou a Universidade. Já se estão realizando os sorteios dos representantes dos professores cathedraticos das differentes Escolas ou Faculdades. O sorteio do representante da Faculdade de Direito será feito logo que seja publicado o decreto federal, que passa para as mãos do Estado essa instituição e que, como é sabido, já está assignado pelo chefe do governo da União.

O Conselho tratará de organizar o regimento interno da Universidade e medidas para a sua imediata instalação. A Faculdade de Direito contribuirá para esse regimento interno universitário com o seu próprio, que está sendo redigido por determinação nossa, pelos drs. Sampaio Doria e Mario Mazagão.

A Faculdade de SCIENCIAS Economicas e Commerciae que deve fazer parte da Universidade não será creada ainda este anno. Provavelmenteo será no próximo anno. Quanto á Escola de Bellas Artes, continuará a funcionar este anno, como até agora sem fazer parte da Universidade, nella ingressando também no anno vindouro.

O melhor das nossas attenções está voltado, agora, para a organização da Faculdade de Philosophia, Sciencias e Letras, que começará a funccionar em junho.

A viagem do dr. Theodoro Ramos está dando resultados magníficos. Na Italia foram contratados 3 professores, dentre os quaes duas celebridades mundiaes. São elles: Luigi Fantopié, professor de Analyse, Calculo Integral e Differencial, da Universidade de Bologna; G. Wataghin, da Academia Militar de da Universidade deTurim, $1^{\circ}$ premio do Concurso da Academia Pontifical de Roma, sobre monographias relativas á theoria dos "quanta"; Francesco Piccolo,professor de latim na Universidade de Roma e de literatura italiana, no Lyceu "Torquato Tasso" de Roma, que se incumbirá, entre nós, de leccionar a língua e a literatura italianas.

Virá também, como professor de Botanica, um professor italiano, que se encontra actualmente na Cyrenaica e cujo nome ainda não conheço.

É necessário salientar as magníficas condições desses contratos. Os professores italianos estão contratados por três annos, tendo-lhes sido garantido o goso de três mezes de férias annuaes na Italia. Tanto os seus vencimentos, como as passagens para elles e para suas famílias, serão pagos pelo governo italiano, que lhes concede também a contagem de tempo em dobro, durante a sua permanência no Brasil. O único onus que nos cabe é o pagamento a cada um delles, de uma gratificação annual de 2.000 a 3.000 liras.

Segundo as informações que nos chegam agora foram contreatados 6 professores francezes. As condições dos contratos são as mesmas dos italianos. Elles terão os seus vencimentos e passagens pagas pelo governo francez. O prof. George Dumas foi a Florença, especialmente para aguardar o Dr. 
Theodoro Ramos em nome do governo francez, informando-o do interesse que este tinha pela sua viagem e de que estava disposto a facilitar-lhe em tudo o cumprimento de sua missão.

O ilustre engenheiro patrício irá em seguida á Allemanha, á Belgica e á Suissa, onde contratará outros tantos sábios de nomeada que virão emprestar do brilho seu saber á nossa universidade.

Esses professores virão para a Faculdade de Philosophia, Sciencias e Letras, mas é preciso notar que as suas lições aproveitarão aos estudantes de outras Escolas e Faculdades, dado que, de accôrdo com o systema universitário as aulas de uma mesma disciplina podem ser dadas em conjuto para os alumnos de differentes escolas.

\section{NOTÍCIA 7}

$14 / 04 / 1942$

AMPLIAÇÃO DO NOSSO SISTEMA EDUCACIONAL - CRIAÇÃO DE MAIS DOZE MIL ESCOLAS.

Discurso do Titular da Secretaria da Educação.

Deu- se, logo depois, a cerimônia Inaugural do Grupo Escolar "S. Geraldo", falando, na ocasião, o prof. José Closel e o titular da Educação e Saude Pública.

Disse, entre outras coisas, o dr. José Rodrigues Alves Sobrinho:

“A qualidade supera sem dúvida, a quantidade. Estas verdades banais estão a indicar e a exigir a imperiosa necessidade de promovermos, sem perda de tempo e com a máxima energia, a ampliação do nosso sistema educacional, infelizmente muito aquém das nossas necessidades. São Paulo, pelo último recenseamento, possue 7 milhões e 300 mil habitants. Nossa população escolar, fixada na proporção usual de 1800 sobre aquele número, alcança o total de 1.314 .000 crianças. Recebem, porem, instrução primária no Estado - instrução estadual, municipal e privada - 800.000 alunos. O Estado, só ele, ministra instrução a 600.000 escolares, divididos por 12.500 unidades. Quer isto significar que existem no nosso território 500.000 crianças sem escola. É potanto, premente e imprescindível a criação de mais 12.000 escolas primárias para serem distribuídas pelo nosso Estado. Somente na Capital, no decurso do ano passado, houve 20.000 pedidos de matrículas inatendidos. A nossa Capital, só ela, precisa de 500 escolas. E este numero crescerá muito se considerarmos que computamos unicamente as crianças que solicitaram e não obtiveram matrícula, deixando de lado muitos milhares, cujos pais, ou responsáveis, por desleixo ou por preverem a inutilidade dos seus esforços, nem siquer se animaram a solicitar matrículas de seus filhos. Não é, assim, exagerado o cálculo de mais de 25.000 crianças que, na Capital, não freqüentam escolas. Para a necessidade de mais de 12.000 escolas o orçamento deste ano só consignou a verba de 500:000\$000 suficiente, apenas, para as 120 escolas que foram disseminadas, em grande parte pelos núcleos de infiltração estrangeira.

Urge providenciar para que cesse essa situação lamentável, que vive a nos envergonhar, comprometendo a nossa capacidade e nossos foros de povo policiado. É imprescindível conjugar, nesse sentido, os esforços do Estado com os dos nossos municípios. O problema a todos interessa, e, portanto, por todos deve e precisa ser solucionado. Allem-se ambos e não poupem sacrifícios para obtenção dos recursos indispensáveis á debelação do mal. O Estado dispende quase 1000 das suas rendas, ou pouco menos de 100.000 contos de réis, com o ensino primário. É pouco, muito pouco. Os municípios paulistas não chegam a gastar 600 dos seus orçamentos com a divulgação do ensino primário.

Nos Estados Unidos, di-lo eminente escritor, os governos estaduais gastam em conjunto, 3900 e os municipais 3500 de seus orçamentos com a instrução

Torna-se preciso que os paulistas que se orgulham muito justamente de tantas glórias, consigam eliminar do seu território a carga corrosiva do analfabetismo. Não podemos, nem devemos permanecer na situação humilhante em que nos debatemos. Estatua o Estado a obrigação dos municípios dispenderem o que for preciso para ajudá-lo, a promover a redenção espiritual dos nossos patrícios. Que 
ninguém, pense em fazer economia quando se falar em matar a ignorância de nossa gente. Recordem-se todos que o que se inverte na instrução e educação do povo é capital que se reproduz a largos juros. Façamos, nesta hora, o solene juramento, de pugnar pelo extermínio impiedoso da ignorância de nosso povo. Só assim seremos bons brasileiros, merecedores da grande terra que Deus nos concedeu". MUNICIPAL

INAUGURAÇÃO DO RETRATO DO PRESIDENTE DA REPÚBLICA E DO NOVO PAÇO

Ás 18 horas, realizaram-se as cerimônias da inauguração do retrato do presidente Getulio Vargas na sede da Prefeitura e do novo edifício do Paço Municipal.

O espaçoso salão de audiências estava repleto. A solenidade da homenagem de Araraquara ao primeiro magistrado da Nação, colocando o retrato de s. exa. Na sede do governo municipal, teve lugar, então, no salão nobre, uma sessão solene.

Falou, em primeiro lugar, o sr. Camillo G.de Sousa Neves, prefeito de Araraquara.

\section{NOTÍCIA 8}

$05 / 03 / 1943$

\section{EMPENHADOS OS DIRETORES DAS ESCOLAS NORMAIS DO ESTADO NA BOA EXECUÇÃO DA REFORMA DE ENSINO A SEU CARGO.}

Entrevista do sr. Israel Alves dos Santos, Diretor do Departamento de Educação - Pequenas Alterações no Projeto - Aspecto Econômico da Questão.

A reforma do ensino normal paulista, projetada pelo governo do Estado, está sendo recebida com gerais aplausos e simpatia, tanto pelos meios técnicos educacionais do país como por todos os que se interessam pelos problemas nacionais, cuja solução é exigida pelo crescente progresso e desenvolvimento do Brasil.

Apreciando o ante-projeto de lei sobre o assunto, estiveram reunidos, recentemente, nesta capital, os diretores de Escolas Normais Oficiais do Estado e demais autoridades do ensino, resultando do congresso um apoio integral á nova orientação estatuída para a formação de nosso magistério primário. A importância dessas reuniões e suas consequiências imediatas para a reorganização do ensino normal de São Paulo foram os temas que propusemos ao sr. Israel Alves dos Santos, diretor do Departamento de Educação, para uma entrevista à "Agência Nacional",

\section{ACEITAÇÃO UNANIME DO PROJETO}

Atendendo o repórter, o diretor do Departamento de Educação, com sua solicitude habitual, prestou-nos os esclarecimentos desejados. Lembrando as reuniões há pouco realizadas no departamento que dirige, mostrou-se muito bem impressionado com a boa ordem dos trabalhos e os resultados práticos desse pequeno congresso de técnicos. Inicialmente, na primeira reunião, os diretores das escolas normais aprovaram, por manifestação unânime, as diretrizes gerais traçadas pela reforma do ensino normal. Não foi esta manifestação um simples apoio formal ou mera prova de acordo impensado á vontade de um chefe. Ao contrário, evidenciou que a reforma veiu atender a uma necessidade evidente que consultava às conveniências gerais de ensino e melhor correspondia aos reclamos e exigências das populações do "hinterland" paulista.

O entusiasmo real com que os diretores dos nossos estabelecimentos de ensino normal acolheram a iniciativa da reforma pode ser verificado, diversas vezes, no decorrer dos trabalhos aqui realizados. Aprovando a orientação geral do ante-projeto de lei, mostraram, ainda, os interessados a sua vontade de colaborar ativamente para que se obtenha o continuo aperfeiçoamento do ensino normal bandeirante, tornando o magistério primário eficiente no desempenho das elevadas funções que lhe estão atribulados.

Comprometeram-se mesmo, todos os participantes das reuniões, a empenhar o máximo de seus 
esforços para a integral e perfeita execução da reforma projetada. Esta espontânea e inesperada manifestação pode ser interpretada, sem exagero, como prova do entusiasmo com que se acolheu o projeto de reforma.

Além disso tiveram as reuniões um outro resultado, que não precisa ser encarecido: contribuiram para uma aproximação maior, um estreitamento de relações entre os diretores dos nossos estabelecimentos de ensino normal, em consequiência do qual se processou uma verdadeira coordenação de atividades normais paulistas.

Maior disciplina e melhor conjugação de esforços foram resultados alcançados, ainda, por essas reuniões.

A presença do sr. Secretário da Educação, nas reuniões da abertura e encerramento dos trabalhos, veiu emorestar maior importância ao certame, traduzindo, outrossim, a atenção especial com que o governo do Estado cuida do problema e o interesse com que desejava a livre e espontânea manifestação da classe sobre a sua iniciativa.

\section{PEQUENAS ALTERAÇÕES AO PROJETO}

Continuando em palestra com o repórter, o sr. Israel Alves dos Santos informou-nos que o projeto de reforma do ensino normal, depois de cuidadosamente estudado pelos participantes das reuniões, não sofreu nenhuma modificação substancial. Alguns detalhes técnicos, pormenores de distribuição de cadeiras, de início das aulas, de nomeação de professores e assistentes, e outros mais foram objetos de sugestões coletivas afim de serem modificados, devendo as referidas sugestões ser encaminhadas e apreciadas pelas autoridades competentes e pelo Departamento Administrativo do Estado.

Entre estas sugestões, quase todas de caráter Impessoal, figura como das mais interessantes a inclusão como parte da cadeira de Sociologia, da História da Civilização Brasileira no primeiro ano do curso normal. O processo de nomeação dos professores e assistentes da Seção de Educação do curso primário, anexo as escolas normais, também, foi objeto de consideração, devendo a sugestão respectiva ser, oportunamente, apreciada e aproveitada segundo a atenção que merecer.

\section{SEGUNDO PASSO PARA A EXECUÇÃO DA REFORMA}

O trabalho preliminar já está realizado _ continuou o nosso entrevistado _ afim de que se revista de inteiro êxito a projetada reformado ensino normal paulista.

O segundo passo está sendo dado pela comissão nomeada pelo sr. Secretário da Educação e Saude Pública afim de organizar os programas mínimos das escolas normais e o plano geral para a completa execução da reforma.

Essa comissão é presidida pelo prof. Almeida Junior e Integrada pelos seguintes elementos: Humberto Pascale Borges Vieira, Francisco Antonio Cardoso, Vicente Sampaio Lara, Rocha Botelho, Luiz Maragliano Junior, Milton C. Silva Rodrigues, d. Carolina Ribeiro, Luiz Motta Mercier, Humberto Sousa Leal, Arthur Campos Gonçalves, Joel Aguiar, João Simões, Juvenal W. Vieira da Cunha, Idílio Abade, Aldo Bartholomeu e Walter Jardim. A esta comissão de técnicos foi atribuída a incumbência de, dentro do prazo de três meses, proceder a elaboração dos programas mínimos das escolas normais e do plano visando o aproveitamento dos institutos especializados, subordinados a Secretaria da Educação, para a execução da prática do ensino constante dos referidos programas, bem como a organização dos cursos de extensão e aperfeiçoamento para membros do magistério primário e normal de São Paulo.

\section{O ASPECTO ECONOMICO}

Quanto ao aspecto econômico que a reforma sugere, afim de que o magistério paulista tenha uma remuneração condigna de suas elevadas funções, disse-nos o sr. Israel Alves dos Santos que o problema foi devidamente estudado e que, alem do reajustamento geral de vencimentos projetado pelo governo para o funcionamento público estadual, a novos encargos do professor deverão corresponder novas retribuições. 

assunto.

É cedo, ainda, para se anunciar pormenores dos planos que o governo está estudando, sobre o

\section{NOTÍCIA 9}

$06 / 03 / 1943$

FOI SUPERIOR, O NÚMERO DE APROPVAÇÕES NOS EXAMES VESTIBULARES ÀS ESCOLAS NORMAIS DO ESTADO.

\section{Em Entrevista Que Concedeu às "FolhaS", o Diretor do Departamento de Educação Declarou Não} Haver Razão Para Reduzir a Média de Notas.

O "Diário Oficial" do Estado acaba de vestibulares ao Curso de Formação Profissional do professor das escolas normais livres, municipais e estaduais, realizados nos dias 20, 21 e 22 de fevereiro de fevereiro ultimo.

O número de aprovações foi, neste ano, bastante superior ao de 1940. No ano passado, como os leitores estão lembrados, houve uma verdadeira derrocada, tendo mesmo, posteriormente, concordado as autoridades escolares em diminuir: o número de pontos exigidos para promoção.

No ano em curso, conquanto os pontos e o critério de julgamento tenham sido os mesmos para todas as escolas do Estado, verificaram-se resultados dos mais desencontrados nos vários estabelecimentos, quer livres, municipais ou estaduais.

Assim houve escola oficial que promoveu 40 alunos dos 43 presentes, como no caso de Guaretinguetá, ao lado de escola normal livre, como a de Jaú, que, dos 49 presentes, só 2 alunos alcançaram promoção. Os melhores resultados foram conseguidos pelas escolas normais oficiais de Guaratinguetá, Catanduva, São Carlos, Franca e "Padre Anchieta", desta capital, todas para com mais de 75 por cento de promoções. Entre as escolas livres e municipais, as de São José dos Campos. Taquaritinga e Itápolis alcançaram: cem por cento de promoção.

Sendo, como dissemos, os mesmos pontos e igual critério para todas as escolas, a que se atribuir esses resultados tão diferente?

\section{DECLARAÇÕES DO DIRETOR DO DEPARTAMENTO DE EDUCAÇÃO}

Foi para esclarecer esse ponto, que procuramos ontem o sr. Antenor Romano Barreto, diretor geral do Departamento de Educação. Atendendo-nos em seu gabinete disse-nos s. s. neste ano tivera o cuidado de convidar para constituírem, as comissões que deveriam se incumbir da organização dos pontos para os nomes vestibulares professores do curso fundamental. No ano passado foram designados os inspetores, para organizar esses pontos.

_ "Os pontos_acrescentou_ nós os publicamos para que o publico os conhecesse e nos avaliasse. Publicámos também o resultado desses exames. Tais resultados dizem bem de como foram razoáveis os pontos para os referidos exames, pois tivemos quasi duas dezenas de escolas normais oficiais e livres, cujas médias de aprovação foram satisfatórias. Tendo-se em vista a totalidade das escolas obtiveram a totalidade das escolas normais, percebe-se que as oficiais obtiveram os melhores resultados. Em algumas, e podemos citar a "Escola Caetano de Campos", muitos alunos que completam o curso ginasial fundamental, principalmente os melhores, destinam-se aos exames vestibulares á Faculdade de Filosofia, Ciências e Letras da Universidade de São Paulo razão também o fato de alunos de outros ginásios buscarem lugares nessas escolas normais".

\section{RIGOROSA VERIFICAÇÃO}

_ Para conhecer perfeitamente o valor dos inúmeros ginásios, tendo-se em vista os exames vestibulares ás normais, acabamos de solicitar dos diretores destas escolas uma relação completa de alunos aprovados e reprovados, dizendo-se de cada um, onde, ou melhor em que ginásio fez o curso 
ginásio.

Com esses dados poderemos orientar a inspeção secundária, no sentido de fazer com que ginásios de fazer com que ginásios de baixa porcentagem de aprovações melhorem, para o próximo ano, essa mesma porcentagem".

\section{NÃO SERÁ REBAIXADA A MÉDIA}

Comentamos em seguida com o sr. Romano Barreto o movimento dos alunos reprovados e que pleiteariam a redução da média dos vestibulares, baseados no precedente aberto no ano passado.

_ "Há razão para pedir-se redução de média?

"Nenhuma respondeu s.s. Os programas de onde foram retirados os pontos para exames, são conhecidos há um ano. Ainda em outubro o novamente, para quem fez um regular curso. Os pontos são realmente razoáveis de ginásio. A matemática -não sei porque razão- considerada a mais difícil, entra com 30 pontos apenas para aprovação.

O total exigido de pontos é de 150, mas há mais matérias para dá-las que são Português, História e Matemática. Não nos parece difícil que em Português e História, segundo os pontos de exames, tire o candidato o mínimo de 120 pontos".

\section{PORTUGUÊS, HISTORIA E MATEMATICA, ELIMINATÓRIAS}

"Esclarecendo o critério adotado para o julgamento, disse-nos que a aprovação é só para quem tem o total de 150 pontos, com os mínimos de 50, 40 e 30, respectivamente, em Português, História e Matemática.

-"Posso garantir - concluiu o nosso entrevistado - que foram tomadas todas as precauções para que, este ano, os exames vestibulares ás escolas normais corressem com absoluta regularidade. Se os resultados não foram idênticos, no sentido das melhores escolas, é que os ginásios que preparavam ou candidatos não são iguais, pois como se sabe, os pontos para todos e para todos foi igual o critério de julgamento".

\section{NOTÍCIA 10}

$12 / 04 / 1944$

APROVADO PELO CHEFE DO GOVÊRNO O PLANO DE REFORMA DO ENSINO NORMAL EM SÃO PAULO

Parecer do Ministro Marcondes Filho- a criação dum novo ano escolar de preparatórios

RIO, 11(Da nossa sucursal) _ O ministro da Justiça encaminhou ao presidente da República a seguinte exposição de motivos da Comissão de Estudos dos Negócios Estaduais:

“Exmo. Sr. Presidente da República.

$\mathrm{O}$ sr. Interventor Federal no Estado de S. Paulo submete à elevada consideração de v. exa. O projeto de decreto-lei que pretende baixar, dispondo sobre a reorganização do Ensino Normal e dando outras providências.

O Conselho Administrativo do Estado aprovou a proposição, fazendo-lhe apenas pequenas emendas que não ferem o fundo da medida.

Na Comissão de Estudos dos Negócios Estaduais, esclareceu o respectivo relator:

"Não se trato pròpriamente de uma reforma, senão de providência destinada a obviar a falta de um ano no atual primeiro ciclo do Curso Secundário. 
Em virtude do Decreto-lei que veio reformar o Ensino Secundário, a fase inicial, que era CE cinco anos (Curso Fundamental) foi reduzida a quatro anos apenas (Curso Ginasial) e tornou-se insuficiente como preparação dos candidatos ao Curso Normal”.

Acrescenta o relator "o que se tem em mira, no caso presente, como em alguns outros já aprovados pela C. E. N. E., é incluir, no Curso Normal, esse ano que a reforma do Ensino Secundário retirou ao seu primeiro ciclo".

Para tal fim, é introduzido nesse ano preparatório que se segue aos quatro anos ginasiais, o estudo das seguintes disciplinas, como acentua o relator "todas indispensáveis para que se integre a preparação iniciada no Ginásio":

Português, 4 horas semanais; História da Civilização Brasileira, 2 horas semanais: Matemática e Noções de Estatística, 3 horas semanais; Ciências Físicas e Naturais, 6 horas semanais; Anatomia e Fisiologia Humana, 3 horas semanais; Música e Canto Orfeônico, 2 horas semanais: Desenho, 2 horas semanais; Trabalhos Escolares, 2 horas semanais; Educação Física, 2 horas semanais.

À vista do exposto, a C. E. N. E. , por unanimidade de votos, opinou pela aprovação do projeto, suprimidos, porém, os dispositivos que dizem respeito a pessoal, bem como o Artigo 8.o, de acordo com sugestão do sr. Luiz Simões Lopes.

Frisou o sr. Simões Lopes que é norma do governo federal tratar, em decreto, em decreto autônomo, da questão do pessoal.

“O número de aulas ordinárias por semana, será de 12 para todos os professores de escolas normais, exceto os professores catedráticos da Escola "Caetano de Campos", que ficam obrigados a 18".

Não encontrou a C. E. N. E. justificação no processo anexo, para essa diferença de tratamento consignada no citado Artigo 8.o, pelo que, a fim de não retardar a solução da matéria principal do projeto, propôs fosse esse dispositivo sujeito a posterior estudo.

Salvo melhor juízo de v. exa.; parece-me que procedem as observações da C. E. N. E. .

Aproveito a oportunidade para reiterar a v. exa. Os protestos do meu profundo respeito. (a) _ Alexandre Marcondes Filho _ Despacho: Aprovado em 31-03-44 (a)_G. Vargas.” 


\section{Anexo II - Década de 1970}

\section{Corpus referente às notícias publicadas na década de 70 do século $\mathrm{XX}$ pelo jornal Folha de S. Paulo}

\section{NOTÍCIA 11}

\section{Folha de S. Paulo 9/03/1972 \\ Aulas excedentes em São Paulo}

A revisão de critério de calculo de aulas excedentes ministradas pelos professores contratados e que implica em prejuízos de vencimentos será proposta pelo Conselho Estadual de Politica Salarial da Secretaria da Fazenda pela secretaria Ester de Figueiredo Ferraz, da Educação.

Sobre o assunto, a asessoria técnica da Secretaria da Educação distribuiu ontem o seguinte comunicado:

“Até a data da publicação do decreto $\mathrm{n}^{\circ}$. 52.874, de 8 de fevereiro último, as aulas excedentes ministradas pelos professores dos estabelecimentos de ensino médio do Estado era contadas e pagas segundo critério constante do Decreto $\mathrm{n}^{\circ}$. 51.575, de 20 de março de 1969, pelo qual, faz efeito do calculo de pagamento, o mês seria calculado quatro semanas e meia.

“Acontece que, no governo anterior, precisamente em julho de 1970, foi propostas por órgãos da Secretaria da Educação a alteração do referido critério, sob a alegação de que esse regime infringiria imposições da Lei $n^{\circ}$. 10.168, de 10 de julho de 1968. Logo a seguir, o assunto foi levado ao exame do Conselho Estadual de Política Salarial, da Secretaria da Fazenda, o qual, em reunião de 26 de julho de 1971, considerando estar "positivado haver uma falha técnica da legislação, que vem acarretando inúmeras distorções e problemas de ordem administrativas, só restava aquele órgão propor a devida correção, o que seria objetivado com a do Decreto minutado pelo Departamento Regional da Grande São Paulo".

“Em virtude dessa resolução, foi baixado o decreto 52.876, que vem sendo alvos de reiteradas reclamações por parte dos professores atingidos.

“Alertada sobre o exato alcance da alteração do critério imposto pelo referido decreto, a prof. Esther Figueiredo Ferraz tomou a iniciativa de fazer preparar, para encaminhar ao Conselho de Política Salarial, fundamentada exposição de motivos no sentido de ser revista aquela decisão, especialmente por haver verificado, segundo os cálculos realizados pelos órgãos técnicos da Secretaria da Educação, que a contagem de aulas excedentes, na forma proposta ainda anularia, ainda com um pequeno acréscimo, para os professores do ensino médio, o recente aumento de vencimentos concedidos pelo Estados aos seus servidores. Caso não seja considerado viável o reexame da questão pelo Conselho Estadual de Política Salarial, a Secretaria da Educação representara ao governo do Estado, propondo seja encaminhada, com urgência, mensagem a Assembléia Legislativa, objetivando a correção da mencionada falha técnica de legislação.

\section{Excedentes do $2^{\circ}$ grau}

Afirmando que "o governo não desconhece a gravidade da situação dos que ainda não conseguiram matricula", a secretaria Ester de Figueiredo Ferraz formou ontem uma comissão que estabelecerá as normas nos convênios a serem firmados com prefeituras do Interior com vista à maior participação dos municípios no atendimento das necessidades escolares do $1^{\circ}$ grau, permitindo os recursos do Estado pra o $2^{\circ}$ grau. 
Teixeira Junior.

Sem a colaboração dos poderes municipais e dos próprios particulares o Governo do Estado não poderá, de imediato, aumentar o atendimento do $2^{\circ}$ grau. Os municípios entenderam perfeitamente o problema e já estão assumindo seu papel nessa tarefa", disse a secretaria da Educação.

Ela informou ainda que grande parte dos recursos orçamentários da Secretaria, cerca de $\operatorname{Cr} \$ 2$ bilhões, foi aplicada na área do ensino fundamental e na ampliação e melhoria da infra-estrutura física da rede escolar.

\section{NOTÍCIA 12}

\section{9/03/1972}

\section{Precariedade das escolas}

Após constatar a precariedade das escolas de emergência instaladas em vários nucleos rurais do município de Bofete durante inspeção de surpresa realizada a obras escolares e rodoviárias do Estado na região, o governador Laudo Natel determinou a Secretaria da Educação que através do Fundo Estadual de Construções Escolares, estude uma solução imediata para o problema.

"Isto, como está, não pode continuar", disse o governador no interior da escola de Emergência do bairro Jacutinga, que visitou em companhia do secretário Henri Aidar, chefe da Casa Civil, e coronel Raul Humaitá, chefe da Casa Militar. A escola, a exemplo de outras 17 existentes em Bofete, não passa de um casebre de poucos metros quadrados de área, piso rústico, sem forro, com uma única janela, que não permite a entrada adequada de ar e luz. O terreno ao redor, poeirento, nos dias de chuva se transforma em lamaçal, dificultando a passagem das crianças que vêm de sítios às vezes distantes, transpondo barrocas e cercas de arame farpado.

"Não é possível manter esta situação"- acrescentou o sr .Laudo Natel. "O Estado permitirá que estas crianças continuem sem condições adequadas para estudar'

\section{Sem excedentes}

O governador manteve também contatos com prefeito João de Pontes Camara , professores e alunos de outras escolas e bairros que o foram saudar, e visitou as obras do ginásio municipal, que estarão concluidas em quatro meses.

"Fico satisfeto em saber que aqui não há excedentes no curso ginasial, problema angustiante que, felizmente, já pertence ao passado" disse o governador Laudo Natel ao visitar depois o Grupo Escolar Estadual Cesário Lange.

Na escola de Cesário Lange, o governador por questão de elogiar o diretor Marcio Antonio de Camargo Barros pelo nível do estabelecimento e registrou suas impressões no livro de visitas. Ficou satisfeito ao verificar que os prazos para construção do Colégio Estadual de Porangaba e do Colégio Integrado - primário e ginásio-de Areiópolis estão sendo cumpridos na forma estipulada. O colégio de Areiópolis está sendo construído pela Secretaria da Educação, através do FECE e seu custo está previsto em 430 mil cruzeiros. 


\section{NOTÍCIA 13}

\section{$13 / 03 / 1972$}

\section{Hoje o plano da reforma}

O plano de implantação de reforma de ensino de primeiro e segundo grau do sistema público e particular de São Paulo será divulgada hoje as 11 horas pela secretaria estadual de educação, professora Esther de Figueiredo Ferraz.

A reforma de ensino de primeiro (antigo cursos primário e ginasial) e segundo (antigos cursos, colegial, técnico e normal) grau será implantada gradativamente. Até 1975 segundo o plano, a reforma já estará totalmente implantada em todas as escolas paulistas de primeiro grau, entretanto, a reforma de segundo grau só estará completamente implantada em São Paulo, em 1978.

A implantação da reforma só começará a ser realizada após a aprovação executiva e normativa do plano. A parte executiva do plano será apreciada pelo Governo do Estado e a normativa pelo Conselho Estadual de Educação, provavelmente nesta semana.

O plano foi concluído sábado pelo Grupo-Tarefa da Secretaria de Educação, seu coordenador geral foi professor Walter Toledo Silva que contou com a colaboração de aproximadamente 100 técnicos e professores para elaboração do planejamento de implantação da reforma.

O plano tem mais de mil páginas, está dividido em quatro capítulos distribuídos em três volumes. Começou a ser elaborado em setembro do ano passado. Os quatro capítulos do plano são os seguintes:

1 - Diagnóstico preliminar da situação geral do sistema de ensino paulista, sua análise e conclusões que dela podem se tirar.

2 - Implantação política de reforma em que se aborda tudo o que deve ser realizado a curto e médio prazo. A curto prazo serão implantadas as medidas seguintes: preparação geral da estrutura física e administrativas e adequação dos recursos humanos do sistema de ensino paulista. A médio prazo se desenvolverão as preparações de curto prazo e a implantação dos novos conteudos pedagógicos.

3- Ações para efetivação da reforma, em que são sugeridas normas e recomendações de um programa de ação para que as medidas do segundo capítulo do plano possam ser realizadas.

4 - Este capítulo encerra recomendações para implantação da reforma, principalmente no que toca a recursos humanos, organizacionais, físicos, financeiros e legais.

Entretanto, somente uma porcentagem mínima dos 4.000 .000 de estudantes das escolas paulistas de primeiro e segundo graus serão, este ano, atingidos pela reforma do ensino. A própria lei 5692 da reforma de ensino recomenda que sua implantação seja realizada dentro dos recursos e possibilidades de cada Estado.

\section{NOTÍCIA 14}

$12 / 03 / 1972$

A reforma total do ensino até 1978

Em São Paulo, a reforma do ensino de $1^{\circ}$ grau que reune os antigos cursos primário e ginasial, estará totalmente implantada até 1975 e a $2^{\circ}$ grau, que compreende os antigos cursos colegial, tecnico e normal, será totalmente implantada até 1978, informou ontem o coordenador do Grupo-Tarefa da Secretaria de Educação, prof. Valter Toledo Silva. 
A secretaria Esther de Figueiredo Ferraz, da Educação, divulgará amanhã, às 11 horas, o plano de implantação da reforma que foi concluido ontem pelo Grupo-Tarefa. O plano tem mais de 1.000 páginas e está dividido em quadro capitulo distribuidos em tres volumes. Foi elaborado desde setembro do ano passado e sua entrega esta dentro tempo previsto pela lei 5.692, que em agosto do ano passado instituiu a reforma de ensino de $1^{\circ}$ e $2^{\circ}$ graus.

\section{DIAGNOSTICO}

Em linhas gerais, os quatro capitulos do plano de implantação da reforma pormenorizam todos os aspectos do ensino de $1^{\circ}$ e $2^{\circ}$ grau, tanto das escolas publicas como das particulares. O primeiro capítulo estabelece um diagnostico preliminares da situação geral do sistema de ensino paulista. Faz uma analise dos dados disponiveis e as conclusões que dela podem se tirar.

A segunda parte do plano compreende a política de implantação da reforma. Nela são apresentados, além dos objetivos gerais, tudo aquilo que deve ser realizado à curto e medio prazo. A curto prazo entende-se as medidas que serão implantadas durante esse proximo ano e que basicamente serão as seguintes: preparo geral da estrutura física e adequação dos recursos humanos dos sistema paulista de ensino.Gradativamente, na medida que o preparo for sendo realizado, serão implantados os aspectos pedagogicos. A concepção politica de novo ensino e nova educação será um modelo estabelecido para servir de orientação e balizamento das medidas instituidas pela reforma que serão emplantadas em todo sistema estadual de ensino publico e particular de São Paulo.

Para o desenvolvimento destes pontos serão criados 40 nucleos de polarização, onde será montado um sistema de acompanhamento e avaliação do plano estadual. Mas, segundo a lei da reforma, não significa que os 40 nucleos desenvolverão o plano ao mesmo tempo, pois sua principal função será de ser piloto de testes das medidas adotadas.

O capitulo três do plano estadual de implataçao da reforma consiste na programação de ações para efetiva-la . Cada um dos sete itens do programa de ação apresenta projetos que indicam a elaboração de outros de forma que o conjunto das ações propostas permita a realização da politica definida pela segunda parte do plano.

$\mathrm{Na}$ quarta parte do plano discutidos os recursos para a implantação da reforma em que se destacam recursos humanos, organizacionais, fisicos, financeiros e legais.

$\mathrm{Na}$ parte de recursos humanos é apresentado o programa de treinamento, capacitação e aperfeiçoamento do pessoal, aproximadamente 100 mil professores na rede estadual de educação tem atualmennte mais de 110 mil professores, que até o fim do ano que vem já deverão estar treinados e aptos para aplicar o plano de reforma.

No setor de organização será implantada a reforma admistrativa, um dos pontos mais dificeis de ser realizado pelo plano estadual, pois esta rede de ensino, antes mesmo da instituição da lei da reforma, já possuia uma estrutura superada devido a atribuições cada vez maior que recebe (entre outras, o aumento, de ano para ano, do numero de alunos).

O plano prevê no aspecto fisico de seus recursos, a utilização racional em tempo e espaço da redistribuição das escolas, reunião de estabelecimentos de ensino, de $1^{\circ}$ e $2^{\circ}$ graus, novos projetos e calendário escolar.

Isto será feito com dois objetivos regularizar a situação existente, em termos de duração do periodo diário de atividades educacionais para possibilitar a colocação de periodos dentro de horários proprios; e fornecer instalações necessárias para o desenvolvimento eficiente das atividades e trabalhos escolares.

\section{DEMORA}

Nos aspectos financeiros e legais são recomendadas medidas para melhor utilização dos recursos disponiveis e propostos meios para que a administração tenha os instrumentos para seu trabalho.

Os prazos de implantação da reforma, para serem cumpridos, dependem de uma serie de fatores, entre eles, a aprovação normativa, que é de competência do Conselho Estadual de Educação. Isto tudo 
deverá começar a ser analisados e estudado nesta semana pelo Governo do Estado e CEE.

A implantação da reforma será gradativa e até 1975 todo o sistema público e particular de São Paulo já deverá ter as oito séries do ensino de $1^{\circ}$ grau funcionando pela lei e plano estadual da reforma. As séries do ensino de segundo (são três nos antigos cursos colegial e técnico e quatro no antigo normal) demorarão até 1978 para funcionarem integralmente dentro das normas da lei e plano da reforma, pois o ensino de $2^{\circ}$ grau será profissinalizante. Entretanto, até 1973, 30\% do contigente atual (120.000 alunos) do ensino do $2^{\circ}$ grau de São Paulo, terão ensino profissionalizante.

\section{NOTÍCIA 15}

Folha de S. Paulo 12/04/1972

Faculdade não é autorizada

O Conselho Federal de Educação deu o primeiro passo para conter a proliferação de escolas superiores no País ao negar, em sua última reunião, realizada em Brasília, autorização para o funcionamento da Faculdade de Administração de Empresa mantida pelo Instituto Lurwell de Ensino Superior de São Paulo. Segundo o voto do relator, aprovado pelo plenário, existem na área 17 Faculdades de Administração, algumas das quais sem numero suficiente de alunos para o preenchimento de vagas sem contar -acrescentou- os prejuízos que poderão resultar para qualidade de ensino.

A Faculdade de Administração de Empresas de Osasco teve seu processo baixado em diligencia porque o currículo não está de acordo com o fixado pelo Conselho.

A Faculdade de Filosofia, Ciencias e Letras, mantida pela Sociedade Civil de Educação Santa Rita de Cássia teve também seu pedido de autorização baixado em diligencia.

\section{Aprovados}

Sete pedidos de autorização e reconhecimento de escolas paulistanas foram aprovados pelo Conselho em sua última reunião. São eles: Faculdade de Filosofia, Ciencias e Letras da Instituição Universitária Moura de Lacerda, reconhecimento dos cursos de Geografia, Historia e de Ciencias Sociais, Matemática, Letras e Pedagogia da Faculdade de Filosofia e Letras; Centro de Ensino da Alta Paulista (CEALPA), autorização para funcionamento da Faculdade de Ciencias Contábeis de Lucélia; Sociedade de Ensino Piratininga, autorização para funcionamento da Faculdade de Educação; Instituto de Ensino Superior da Região de Bragantina, de Bragança Paulista, autorização (com restrições) para o funcionamento da Faculdade de Educação das Faculdades Integradas Santo Antonio de São Paulo (Capital); Sociedade Educacional Nova Piratininga, autorização para o funcionamento da Faculdade de Educação e Ciências; União da Associação de Ensino de Ribeirão Preto (UNAERP) regimento da Faculdade de Educação; Centro de Estudos Universitários de Praia Grande, autorização para o funcionamento da Faculdade de Educação.

\section{NOTÍCIA 16}

\section{$13 / 04 / 1972$}

\section{MOBRAL na segunda etapa}

A direção do MOBRAL anunciou ontem durante a sessão plenária do II Encontro Nacional que se realiza no Hotel das Paineiras, no Rio de Janeiro, o lançamento em agosto da segunda etapa dos cursos de Educação integrada em todo o País nos municipios que já vêm promovendo em carater experimental a primeira fase.

Os cursos de Educação Integrada ( $1^{\text {a }}$ etapa) que vem sendo realizados desde 1970 , condensada em apenas 13 meses todo o curriculo escolar das quatro primeiras series do ensino do primeiro grau, 
tendo carater profissionalmente. A segunda etapa pretende, com base Reforma de Ensino, cobrir em 13 meses todo o programa da quinta, sexta, sétima e oitava séries do Ensino Fundamental.

O II Encontro Nacional do MOBRAL iniciada segunda-feira, pretende apresentar até o dia 18, um balanço das atividades de 1971 e a programação de 1972. Participam do Encontro coordenadores de todos os Estados e territórios além de elementos das equipes técnicas e administrativas das coordenações estaduais. Através de trabalhos em grupo, por região, estão sendo analisados os programas de implantação das comissões municipais do MOBRAL, o desenvolvimento e acompanhamento dos programas educacionais, o funcionamento interno das coordenações e seu relacionamento com o órgão central. Quanto a administração o Encontro está examinando novos procedimentos contábeis do MOBRAL, regime de gastos e controle dos suprimentos e remessas de parcelas referentes aos convênios com os municípios. As equipes técnicas fazem um estudo sobre o acompanhamento dos programas educacionais, bem como a fundação dos programas de educação integrada e integração MOBRALSecretaria de Educação.

\section{EM SÃO PAULO}

"O trabalho do MOBRAL em São Paulo está se desenvolvendo em ritmo acelerado. Podendo-se prever para dentro de seis anos no máximo a erradicação do analfabetismo em todo o Estado", revelou o coordenador de entidade no Estado Luiz Tomazzi.

O MOBRAL já atingiu em São Paulo a 539 municípios dos 571 existentes, envolvendo desde sua implantação em 1970, cerca de 430.000 alunos. Foram firmados 1153 convênios com as comissões municipais. Só para o Curso de Alfabetização Integrada. Além dos 24 municípios onde está sendo testado o curso de alfabetização integrada. A coordenação de São Paulo já instalou, com base nessa experiência, 93 novos cursos em vários municípios o Estado.

\section{SÃO PAULO}

Em 1871, São Paulo foi o quinto Estado do país de menor evasão de alunos matriculados nos cursos do MOBRAL e de melhor indice de rendimento. A evasão segundo os estudos que estão sendo realizados neste Encontro, se deve a três fatores e deficiência de visão que está sendo corrigida através de campanhas comunitárias de fornecimento de óculos aos educandos, a divisão ciclica das varias culturas agricolas, que exige mais esforço e toma muito tempo do homem do campo e a mudança de emprego e domicilio dos alunos.

\section{NOTÍCIA 17}

\section{$25 / 04 / 1977$}

\section{Até fim do ano MEC não permite novos cursos}

Rio (Sucursal) - O conselho Federal de Educação vai discutir sua reunião plenária mensal que começa $2^{\circ}$ feira, novos critérios de autorização para o funcionamento de novos cursos superiores. A informação foi dada ontem pelo professor Newton Sucupira em palestra feita na Universidade Federal do Rio de Janeiro.

Até o final do ano, o Ministério da Educação não vai autorizar o funcionamento de novos cursos afirmou o professor Sucupira, depois de fazer uma abordagem sobre o ensino brasileiro em que procura negar uma queda de qualidade em termos globais na Educação do País.

\section{MERCADO DE TRABALHO}

O professor Newton Sucupira informou, ainda que o Conselho Federal de Educação vai estabelecer um calendário que prevê tempo determinado para receber pedidos de autorização para novos cursos e prazos prévios para a decisão. Os novos critérios deverão, segundo o conselheiro considerar não apenas o de trabalho dos novos cursos, mas as suas reais necessidades sociais. 
As escolas terão que justificar a criação dos novos cursos e o MEC irá confrontá-las com critérios próprios, levando em conta. Inclusive o problema de distritos educacionais da região e do próprio País. Entretanto, ainda que o mercado de trabalho esteja saturado, o curso poderá ser autorizado, se contribuir para o aperfeiçoamento de padrão, dentro de um critério de excelência - assegurou o professor Sucupira, presidente da comissão que estuda o assunto .

O anteprojeto dos novos critérios já está elaborado e o plenário já fez a incorporação da emenda que terá de ser homologada pelo ministro da Educação. Pelo anteprojeto, o Conselho Federal de Educação poderá propor um programa de necessidades sociais e de áreas específicas e os novos critérios poderão começar a vigorar ainda este ano

\section{RECONHECIMENTO}

A pós-graduação não está incluida nestas normas e o reconhecimento de cursos já existentes é considerado prioritário pelo Conselho, disse o professor Sucupira, acrescentando que o problema das faculdades ainda não reconhecidas é culpa das próprias escolas que formam turmas e não entram com pedido de reconhecimento. Segundo o conselho, as faculdades frequentemente negligenciam e não atendem com presteza ás exigências para o reconhecimento. Por isso, o MEC baixou normas proibindo vestibulares nas faculdades que até o segundo ano de funcionamento não entrem com processo de pedido de reconhecimento.

Ainda sobre a proliferação de cursos, o prof. Newton Sucupira afirmou que a expansão foi detida desde o segundo semestre do ano passado, quando o MEC tinha mais de 100 pedidos que não foram atendidos, enquanto em 1972 houve 320 autorizações.

\section{QUALIDADES}

Falando sobre o ensino brasileiro, o prof. Newton Sucupira disse, durante o debates, ser falso o conceito de queda de qualidade, havendo mesmo no seu entender, um aumento gradual de rendimento.

"Hà "ilhas" de péssima qualidade, mas no conjunto não houve quebra de qualidade. Num balanço global, o ensino superior não está decadente, se considerarmos os padrões de antigamente". E prosseguiu:

"Não submergimos num mar de má qualidade, mas temos muito que fazer principalmente em relação ao acesso às escolas onde há desigualdade entre a maioria e as famílias abastadas".

O prof. Newton Sucupira declarou-se favorável a uma elitização cada vez maior nos cursos de pós-graduação, tornando rigoroso o acesso a eles. E justificou sua posição através de citações de autores russos.

\section{NOTÍCIA 18}

$29 / 04 / 1977$

\section{7 e ensino gratuito vão ficar, segundo o ministro}

Brasilia (Sucursal) - "O Governo Geisel não vai instituir o ensino pago nas escolas publica do País', por entender que não será resolvido, dessa maneira, o problema da falta de recursos para o setor educacional. Da mesma forma, não pretende reestruturar a atual legislação estudantil, que ainda não foi suficientemente testada para que possa ser considerada insatisfatória".

Essas informações foram dadas ontem pelo ministro Nei Braga da Educação, durante depoimento de quatro horas que prestou perante a Comissão de Educação e Cultura do Senado Federal. O ministro estava acompanhado de quase toda a sua assessoria - alguns, inclusive, vindos especialmente do Rio, como o presidente do Mobral - mas não precisou valer-se de seus auxiliares, pois não houve o esperado debate com os cinco senadores que o interpelaram. O ex-ministro da Educação e atual senador Jarbas 
Passarinho (Arena-PA) não compareceu, preferindo prestigiar a instalação da CPI sobre a mulher.

\section{DIREITOS HUMANOS}

O senador Itamar Montoro (MDB-MG) indagou ao ministro da possibilidade de ser incluida entre as disciplinas do curso superior referente aos direitos fundamentais do homem. Nei Braga respondeu que solicitará a seus assessores que analise a sugestão do parlamentar, mas que inicialmente, acredita que tal matéria possa ser ministrada na disciplina de Estudo de Problemas Brasileiros.

Outra pergunta formulada pelo senador mineiro foi com relação à legislação estudantil. Ele quis saber se o MEC não tem intenção de reestudá-la, obtendo a seguinte resposta: "Não, pois a atual legislação não dói (sic) ainda suficientemente testada para que possamos considerá-la insatisfatória".

Sobre a instituição do ensino pago no Brasil, tese defendida quase que unanimente pelos senadores, o ministro disse ser contra a medida e que durante sua gestão ela não será adotada. Respondendo diretamente ao senador Evilásio Vieira (MDB-SC), afirmou que "respeita tal ponto de vista, (favorável ao ensino pago), mas não acredita ser essa a solução para o problema da falta de recursos financeiros no setor educacional", conforme insinuou o parlamentar.

Durante seu pronunciamento, o ministro Nei Braga procurou mostrar-se preocupado com a função humanistica da Educação, afirmando que é fundamental aliar à função de formação de recursos humanos à função humanística da Educação.

Disse, ainda o titular da Educação que é condenável a capacitação profissional a quem não tiver compreendido, antes de tudo, "a consciência de seu papel na sociedade, de sua posição na história, de seus deveres e de seu relacionamento humano".

\section{POLÍTICA}

Embora ressaltando que não estava defendendo a tese do pluripartidarismo, o ministro Nei Braga fez uma sugestão aos parlamentares no sentido de que cada partido possua departamentos especializados em determinado problema ou setor nacional.

Acrescentou que "um partido concentraria sua atenção nos problemas educacionais, em outro nas questões ligadas à agricultura, um terceiro nos setores econômicos e assim por diante. Mas como não há pluripartidarismo isso pode ser feito através das duas agremiações existentes".

\section{DADOS QUANTITATIVOS}

Apresentando uma série de dados estatísticos o ministro procurou demonstrar numéricamente a evolução do setor educacional nos últimos três anos e os programas elaborados e executados por seu Ministério.

Falou sobre todos os setores do MEC, inclusive o de esporte e cultura, salientando, entre todas as atividades, o programa de Crédito Educativo, implantado no ano passado. Segundo suas informações, o número de alunos beneficiados com tal financiamento passou de $150 \mathrm{mil}$, em 1976, para 280 mil, neste ano.

Ressaltou também a verba orçamentária da Empresa Brasileira de Filmes (Embrafilmes), que receberá este ano 100 milhões de cruzeiros, além dos 80 milhões recebidos em setembro de 1976.

Na área do Mobral, informou que o MEC está procedendo a um estudo sobre os indices de regressão escolar, a fim de conhecer quais as causas reais do fenômeno e descobrir novas metodologias e processos que possam evitá-lo.

Sobre o setor desportivo, disse que o Departamento de Educação Física e Desportos está estudando a desvinculação da CBD das áreas de natação e atletismo, para as quais serão criadas duas Confederações especificas. 


\section{AGRADECIMENTO}

Ao concluir seu pronunciamento o ministro Nei Braga agradeceu aos senadores o convite para que participasse da Comissão de Educação daquela Casa, afirmando que "aqui me senti em casa e todos os meus assessores também puderam ficar à vontade".

"Nosso relacionamento deverá multiplicar-se, franco e aberto, e permanente a cada dia. Estou e estarei sempre às ordens e atento às proposições e contribuições oportunas que houver por bem apresentar ou solicitar dessa casa. A todos expresso meu forte empenho em manter um vivido e proficuo intercâmbio que nos coloque, sempre, em sintonia com os grandes problemas da educação nacional concluiu o ministro.

\section{NOTÍCIA 19}

\section{$07 / 03 / 1978$}

Crianças não podem frequentar escola por falta de carteiras

Mais de 1600 escolares regularmente matriculados na Escola Estadual de $1^{\circ}$ grau Dr. Henrique Smith Bayma e Escola Estadual de $1^{\circ}$ Grau Jardim Noêmia- que funcionam em um mesmo prédio, no Itaim Paulista- não podem assistir aulas desde o dia 13 de fevereiro porque nenhuma das 16 salas de aulas tem carteiras para acomodar os alunos. Além da falta das carteiras, os professores enfrentam um outro problema, a falta de água, pois até agora a Sabesp não providenciou a ligação do prédio à rede de água alí existente.

Ontem, a exemplo do que vem ocorrendo desde o dia 13 de fevereiro, centenas de crianças compareceram à escola, respondeam chamada e foram dispensadas em seguida. Ocorre que os escolares, para se apresentarem na escola devem estar devidamente uniformizados e prontos para assistir aula, o que implica trabalho redobrado para as mães, que são obrigados, em função da ausência das aulas, a aguardar que seus filhos respondam a chamada e voltem para casa.

A situação irregular das Escolas de $1^{\circ}$ Grau dr. Henrique Smith Bayma e Jardim Noêmia motivou diversas reclamações; houve uma reunião com as APMs, na qual os professores explicaram que a irregularidade deverá ser sanada o mais rápido possível, pois o delegado de ensino de $10^{\text {a }}$ Delegacia havia assumido o compromisso de normalizar a situação.

Segundo explicações do delegado de ensino aos pais de alunos, há falta de carteiras porque a firma vencedora da concorrência não cumpriu os prazos prometidos, mas- dizia ele há duas semanastudo já foi providenciando e brevemente as crianças terão aulas regularmente.

Entretanto, os dias foram passando e até ontem nenhuma providência havia sido tomada nem com relação ás carteira, nem quanto a ligação da água. Inúmeras mães de alunos estão deixando de levá-los á escola, uma vez que não há aula, se saber, todavia, ausência implica falta, pois a chamada é feita regularmente, o que poderá, no futuro, trazer complicações para as crianças.

\section{NOTÍCIA 20}

\section{$14 / 03 / 1978$}

Criticado o ensino de $2^{\circ}$ grau no MEC

BRASÍlIA (Sucursal)- Apontando falhas na política de ensino de $2^{\circ}$ grau, o diretor do Departamento de Ensino Médio do MEC, coronel afirmou ontem que esse setor está sendo relegado a segundo plano pelo próprio ministério e que atualmente a rede privada é que vem "socorrendo o ensino de $2^{\circ}$ grau no Brasil". 
Para o diretor do DEM, o ensino médio no país está caminhando a passos largos, para o mesmo impasse surgido no ensino superior, quando apareceu a figura de excedente. Na sua opinião, o acesso dos formados no $2^{\circ}$ grau vem se tornando um problema de maior gravidade uma vez que é pequeno o número de vagas nas escolas- tanto oficiais como particulares - em vista do número de candidatos.

A criação dos "vestibulinhos" (exames feitos pelos candidatos aos cursos de $2^{\circ}$ grau) segundo disse, é um sintoma do problema que está se tornando grave em todo o país, uma vez que cresce dia a dia, a pressão exercida pelo $1^{\circ}$ grau sobre o segundo.

Outra questão considerada grave é a falta de articulação entre o $2^{\circ}$ grau e a universidade.

O coronel criticou também a distribuição de recursos financeiros, por parte do Ministério da Educação, lembrando que o ensino de $1^{\circ}$ grau, por ser obrigatório, tem os cuidados dos sistemas estaduais de ensino e, além disso, é dotado de recursos de salário-educação e de outras fontes, enquanto que, para o ensino superior, o MEC desvia a maior quantia de recursos, por ser esse "um problema de ordem política".

Informou que, neste ano, de um total de 1 bilhão e 509 milhões de cruzeiros, prèviamente distribuidos, seu departamento só contará com 102 milhões de cruzeiros para destinar a todas as escolas particulares que recebem auxílios do MEC e a todos os sistemas estaduais de educação.

Essa verba, segundo disse, era um pouco maior até janeiro, mas a Secretaria-Geral do MEC solicitou a devolução de 28 milhões de cruzeiros e determinou que não fossem aplicados outros 18 milhões.

O coronel Torquato Jardim, falando sobre a situação do Departamento de Ensino Médio quando o ministro Nei Braga assumiu o Ministério, em 1974, disse que o setor se encontrava totalmente desorganizado; havia no Tribunal de Contas da União cerca de 20 processos de colegiais agrícolas, estava caracterizado um total desconhecimento da legislação e a maioria das escolas técnicas se encontrava sob intervenção federal, além de se achar o Programa de Desenvolvimento do Ensino Médio (Prodem) a beira de uma crise, que logo depois de concretizou, sendo encerrada as suas atividades.

Existiam ainda outros problemas, disse como o desajustamento do Centro Nacional de Aperfeiçoamento de Pessoal para a Formação Profissional (Cenafor) o desentendimento entre os conselhos estaduais e os diretores de escola e por fim o mais sério deles, segundo o coronel: a falta de diretrizes para o $2^{\circ}$ grau e para o próprio ministério.

\section{MATRICULAS}

Segundo o diretor do DEM, o ministro Nei Braga proibiu a abertura de novas escolas técnicas federais. A proibição é definitiva e o MEC não quer, inclusive manter as 23 escolas técnicas federais, os 21 colégios agrícolas, os 7 ginásios agrícolas e os quatro colégios de Economia Doméstica Rural, preferindo transferi-los para secretarias estaduais.

Esse comportamento da Ministério da Educação e das próprias Secretarias de Educação, que tem responsabilidade sobre esse nível de ensino diretamente, provocaria uma distorção bastante séria nesse setor da educação: de 12 milhões a 452 mil e 953 pessoas em idade escolarizável- 15 a 19 anos- apenas 2 milhões 173 mil e 821 conseguiram dar sequencia aos estudos.

Torquato Jardim lembrou que de todos os Estados os que se encontram em situação mais grave são: Minas Gerais de 1 milhão 428 mil 350 pessoas de 15 a 19 anos apenas 233 mil se acham matriculadas: São Paulo de 2 milhões 411 mil, somente 686 mil estão cursando o $2^{\circ}$ grau- e Paraná- de 1 milhão e 6 mil, apenas 122 mil estão estudando efetivamente. 


\section{Anexo III - 1 Década do Século XXI}

Corpus referente às notícias publicadas na $1^{\circ}$ década do século XXI (período de 2001 a 2009) pelo jornal Folha de S. Paulo

\section{NOTÍCIA 21}

São Paulo, sexta-feira, 30 de março de 2001 FoLha dE S.PAulo bYaSi]

\section{GOVERNO}

Obra com foto de evento tucano integra Programa Nacional do Livro Didático; ministério nega haver propaganda

\section{Livro do MEC destaca imagem do PSDB}

LUIZA DAMÉ

DA SUCURSAL DE BRASÍLIA

O deputado Waldomiro Fioravante (PT-RS), que recebeu uma cópia da página e da capa do livro, apresentou na Câmara um requerimento de informações ao MEC para saber os critérios de escolha da obra e o custo total.

Fioravante disse que vai entrar com ação contra o ministro Paulo Renato Souza por crime de responsabilidade.

Na opinião do deputado petista, recursos públicos estão sendo utilizados para fazer propaganda do PSDB em ano pré-eleitoral. "Há um visível direcionamento político-partidário", afirmou.

\section{Ministério}

Segundo Fioravante, também serão impetradas ações de ressarcimento dos recursos gastos na aquisição do livro e de apreensão dos exemplares já distribuídos aos colégios da rede pública. A Folha procurou o ministro Paulo Renato para falar sobre o livro, mas sua assessoria de imprensa informou que quem daria as explicações pelo MEC seria a secretária de Ensino Fundamental, Iara Prado. Segundo a secretária, o MEC não concorda com a avaliação de que o livro faz propaganda do PSDB.

"Não existe proselitismo. O livro foi avaliado em 1998, no último ano do governo. Nós nem sabíamos se o presidente (Fernando Henrique Cardoso) seria reeleito", argumentou Iara Prado.

"Se naquela época o autor tivesse escolhido uma foto do PT e o livro se enquadrasse nos critérios de exclusão, seríamos acusados de perseguição", completou.

A secretária disse que a foto está de acordo com o tema tratado no capítulo.

Segundo ela, cada livro incluído no guia do MEC -utilizado pelos professores para escolher as obras - é analisado por pelo menos dois professores universitários da área.

"Se há divergências, um terceiro é consultado. Há livros que passam por até oito consultores", disse a secretária.

Um dos consultores que analisaram o livro de estudos sociais, Holien Gonçalves Bezerra, professor aposentado da UFGO (Universidade Federal de Goiás), afirmou que a utilização de uma foto de congresso do PSDB não caracteriza propaganda, porque a ilustração está "contextualizada".

"Não é propaganda de um partido. O texto trata de partidos políticos, e a foto retrata uma realidade. 
Poderia ser uma foto do PT", afirmou.

Segundo o professor, as pessoas que avaliam os livros "nem são do governo".

Pela classificação do MEC, o livro tem uma estrela. Ou seja, é recomendado, mas com ressalvas -não tem erros conceituais nem preconceitos, mas os professores têm de complementar as lições.

\section{NOTÍCIA 22}

São Paulo, terça-feira, 16 de abril de 2002 FolHa de S.Paulo Cotidiano

\section{EDUCAÇÃO}

Mães pedem a reprovação dos filhos, alegando que eles não aprenderam a ler mesmo depois de vários anos na escola

Aluno analfabeto põe avaliação em xeque

IURI DANTAS

DA REPORTAGEM LOCAL

A progressão continuada, sistema de ensino adotado em 98 pelo Estado de São Paulo, permitiu que alguns alunos terminassem os primeiros anos de estudo sem saber ler e escrever. Em razão disso, pais de alunos têm pedido que seus filhos sejam reprovados. A Secretaria de Estado da Educação não tem estimativa de quantos alunos estão nessa situação.

São casos como o da recepcionista Maria Cristina, mãe de D., 12. Ela pediu que D. não fosse para a quinta série, apesar de já ter cursado a quarta série duas vezes. Isso aconteceu em janeiro, no município de Votorantim (a 108 km de São Paulo), na Escola Municipal Abimael Carlos de Campos.

A mãe apresentou um motivo bem simples para que seu pedido fosse atendido: o filho, mesmo depois de cinco anos na escola, não sabia ler nem escrever. A cidade adotou o regime de progressão continuada em 1998, em conjunto com o Estado.

O menino, segundo a mãe, apresentava dificuldades de aprendizagem desde que começou a estudar. Mas, afirma ela, D. nunca recebeu apoio médico ou psicológico na escola.

D. acabou sendo reprovado em 2000, quando se submeteu pela primeira vez a uma avaliação, já na quarta série. No ano seguinte, segundo a mãe, o menino continuava na mesma situação: sem saber ler ou escrever. Mesmo assim, a aprovação para a quinta série foi automática -pelas regras atuais, um aluno só pode repetir uma determinada série uma única vez. A pedido e insistência da mãe, ele foi novamente matriculado na quarta série.

Segundo a secretária municipal da Educação de Votorantim, Neuza Aparecida Móra, além de D., foram detectadas outras 53 crianças da quarta série (de um total de 1.827) que não tinham condições de passar para o ciclo seguinte. Como já haviam repetido um ano durante o ciclo, mesmo com deficiências, matricularam-se na quinta série.

Em Ribeirão Preto (a 314 km de São Paulo), um grupo de 25 mães procurou o Conselho Municipal de Educação para reclamar que os filhos também não haviam sido alfabetizados. Segundo Walter Colombini, presidente do conselho, um desses alunos já terminou a oitava série.

\section{Copiar letras}

L., 13, que está na sexta série, repetiu a quarta na Escola Estadual Cordelia Ribeiro Ragoso, em Bonfim Paulista (distrito de Ribeirão Preto). O menino aprendeu a copiar letras, mas lê como um aluno da 
primeira série, disse a mãe à Folha.

\section{Inquérito}

O Ministério Público abriu, em 21 de novembro de 2001, um inquérito civil para investigar a legalidade do Saresp (Sistema de Avaliação Escolar do Estado de São Paulo). Quando tomou conhecimento do modelo de ensino, o promotor Vidal Serrano Junior resolveu "expandir" o procedimento e abranger "a progressão continuada como um todo".

A expectativa é que seja feita uma ação civil que solicite à Secretaria da Educação mudanças no modo de avaliação.

A tese do promotor Serrano Junior é que cada escola, em integração com a comunidade de pais de alunos, pode elaborar a forma de avaliação a ser adotada.

"Em princípio, a idéia é fortalecer a ligação entre a escola e a comunidade, o que é recomendado pela Lei de Diretrizes e Bases da Educação", afirmou o promotor.

\section{Exclusão social}

A progressão continuada está "refinando" o processo de exclusão social no Estado, afirma a diretora da Faculdade de Educação da Universidade de São Paulo, Selma Garrido Pimenta.

Ela questiona o fato de que, mesmo recomendado pela LDB, o modelo de progressão por ciclos tenha sido adotado apenas na rede pública. A seu ver, isso joga para o vestibular a efetiva comparação entre as metodologias de ensino das redes pública e particular.

Outro item apontado por Selma é a forma de implementação do sistema no Estado. Não houve, de acordo com a educadora, "significativas alterações" na forma de a escola se organizar e funcionar. "O resultado é que, na verdade, os alunos estão sendo aprovados automaticamente, sem que a escola tenha recebido as condições para entrar nessa nova sistemática. Houve um atropelo e uma falta de cuidado com esses aspectos."

Maria Isabel Noronha, presidente da Apeoesp (Sindicato dos Professores do Ensino Oficial de São Paulo), concorda com Selma: o problema está na forma como o regime foi introduzido.

Antes da implantação, afirma, deveria haver mudanças nas condições estruturais das escolas, como a diminuição do número de alunos por sala de aula e o aumento do salário dos professores.

"O objetivo da progressão continuada é avaliar o aluno o tempo todo, mas, sem estrutura, os professores não conseguem fazer isso, e acaba virando uma aprovação automática", disse.

São Paulo, terça-feira, 16 de abril de 2002 FolHa de S.PALlo COtidiano

\section{OUTRO LADO}

\section{Secretário-adjunto diz que existem só "casos pontuais"}

\section{DA REPORTAGEM LOCAL}

"São casos absolutamente pontuais", disse Hubert Alqueres, 40, secretário-adjunto da Educação do Estado de São Paulo, ao ser questionado sobre alunos que permanecem analfabetos depois de quatro anos de estudo.

Além disso, para o dirigente, o problema estaria na escola, já que cada aluno teve quatro professores, um coordenador pedagógico e um diretor acompanhando sua vida escolar no período. Essa equipe é que será "acionada" para verificar responsabilidades administrativas.

Segundo Alqueres, os resultados do Saresp de 1998 e 2001 jogam uma pá de cal sobre as críticas à progressão continuada. A média de acertos dos alunos, que era de $48,5 \%$ das questões, aumentou para $54,5 \%$ e $55,7 \%$ na primeira e segunda fases do exame, respectivamente.

"Após quatro anos, os alunos tinham aprendido mais. Isso não significa que não existam casos problemáticos, em que não seja atingido um desempenho satisfatório. Nesses casos pontuais, os alunos 
têm de passar por recuperação de ciclo. Pretendemos acionar as escolas para ver o que está acontecendo. Se percebermos que é uma forma de "boicote", aí teremos de cobrar responsabilidade." (ID)

\section{NOTÍCIA 23}

\section{São Paulo, quarta-feira, 17 de março de 2004 FolHa de S.PALlo COtidiano}

Em novembro, MEC vai avaliar alunos de 13 cursos no país

FERNANDA MENA

DA REPORTAGEM LOCAL

\section{LUCIANA CONSTANTINO}

DA SUCURSAL DE BRASÍLIA

\section{Críticas}

Alguns especialistas, no entanto, consideram o novo sistema como mera seqüência daquele que instituiu o Provão. "O que há de novo no sistema? Não há nada. Tudo já vinha sendo feito, inclusive a avaliação da responsabilidade social. Não há muito o que inventar nessa área", avalia Paulo Renato Souza, exministro da Educação nos dois mandatos de Fernando Henrique Cardoso (1995-2002) e responsável pelo implemento do antigo sistema de avaliação do ensino superior.

Para a atual equipe do Ministério da Educação, o Sinaes é um avanço, pois possibilita visão integrada do aluno, infra-estrutura e qualidade de ensino ao estabelecer um único índice de avaliação.

Afrânio Catani, professor na Faculdade de Educação da USP e membro do Fórum de Políticas Públicas, diz que "o sistema é um misto do Provão com a proposta original do Sinaes (apresentada por uma comissão criada pelo MEC), que perdeu suas características essenciais".

\section{Enade}

Como ainda será definido o peso de cada um dos três indicativos no cômputo do índice, há quem ainda desconfie que, na implementação, o Sinaes possa ser uma troca de seis por meia dúzia.

"É um avanço condicionado ao peso que será dado à prova no índice final de avaliação", afirma Gustavo Petta, presidente da UNE (União Nacional dos Estudantes), entidade historicamente contrária ao Provão.

Para ele, o fato de o projeto ter sido construído coletivamente democratizou a avaliação. "Mas esse avanço democrático é contraditório à permanência da obrigatoriedade do exame."

O Enade será feito de três em três anos -o Provão era anual. O exame agora será obrigatório só para os alunos sorteados para a amostragem.

"É complicado usar amostragem", avalia o reitor da Unicamp, Carlos Henrique de Brito Cruz. "Como será feita a cobertura? É uma avaliação relativa."

Para Adolpho José Melfi, reitor da USP, "falta uma avaliação que indique mudanças nos rumos da universidade". Esse tipo de diretriz, segundo ele, a USP conseguiu com auto-avaliações. "O projeto é um passo à frente, mas ainda precisa de ajustes", diz Paulo Alcântara Gomes, presidente do Crub (Conselho de Reitores das Universidades Brasileiras). Desde 2001, o Crub implantou um sistema de avaliação. A partir de seu resultado, as instituições se propõem a mudar aquilo avaliado como insuficiente.

\section{Ajustes}

Como ainda não estão definidos, os conceitos ideais a serem aplicados no Sinaes geram dúvidas. Uma 
preocupação para o professor Daltro José Nunes, da Universidade Federal do Rio Grande do Sul, é a definição do conceito de responsabilidade social, aplicado na avaliação da instituição segundo o novo sistema.

Para Paulo Renato Souza, o problema será a implementação. "A lei é boa porque acolhe o que o Provão fazia e abre alternativas. A questão é saber a linha que o governo vai adotar [na regulamentação da proposta]."

\section{NOTÍCIA 24}

São Paulo, terça-feira, 27 de abril de 2004 FolHa de S.PALlo Cotidiano

\section{EDUCAÇÃO}

São atribuídos à comissão que analisa obras de ciências desde erros conceituais até críticas que não procedem

\section{Autores criticam avaliação de livros didáticos}

\section{Qualidade}

O presidente da Abrale, Gelson Iezzi, diz que a entidade não é contra a avaliação, que funciona, segundo ele, como um autocontrole para as editoras e autores, melhorando a qualidade dos livros didáticos. Quer, sim, que ela seja revista, principalmente em dois pontos: a escolha dos membros da comissão, cujas bases, alega, não são claras, e a sistemática do processo de análise.

Segundo ele, entre os avaliadores nomeados por Bizzo, a maioria está em cursos de pós-graduação, sem experiência em sala de aula. "Não há critério para escolha nem para a continuidade do grupo", afirma. O ideal, diz, é que participassem da comissão também representantes das escolas, professores e de entidades da sociedade civil.

Em relação ao processo de avaliação, a Abrale defende que ele seja contínuo e possibilite aos autores e editoras responder às críticas e corrigir eventuais erros antes de o livro ser excluído da lista do MEC por causa desses problemas.

"Em vez de avaliação, queremos uma certificação ininterrupta, não necessariamente vinculada à compra dos livros, o que evitaria correria por parte dos autores na elaboração dos textos e possibilitaria também às escolas ter mais tempo para conhecer e escolher as publicações aprovadas", defende.

Nesse caso, a obra costuma ser rejeitada também pelo resto do mercado -uma vez que os resultados da avaliação são divulgados no site do MEC. As editoras não sofrem tanto dano porque costumam submeter várias publicações diferentes à avaliação, uma das quais acaba aprovada.

A Abrelivros (associação das editoras) não subscreve o documento da Abrale, embora defenda algumas das mudanças estruturais propostas por ele, como o direito de réplica e alteração do cronograma das avaliações.

Para ilustrar as deficiências do atual modelo de avaliação, a Abrale cita no seu documento o que considera erros cometidos pela comissão de ciências.

Experiência

O documento cita o que considera outros erros conceituais e de avaliação metodológica. Segundo a vicepresidente da Abrale, Vera Duarte de Novais, a crítica está centrada nos livros de ciências porque são o caso mais emblemático de problemas na avaliação, mas ela se aplica a todas as disciplinas. "O modelo é extremamente frágil e vulnerável", sustenta. 
São Paulo, terça-feira, 27 de abril de 2004 FolHa de S.PAulo COtidiano

OUTRO LADO

Coordenador e ministério apóiam comissão

DA REPORTAGEM LOCAL

Em resposta oficial ao documento que questiona a avaliação dos livros didáticos de ciências, enviado à Abrale, a secretária de Educação Fundamental do MEC, Maria José Vieira Feres, defende o processo de análise e diz que seus resultados já foram contestados na Justiça, sem sucesso.

O coordenador da comissão que analisa os livros, professor Nélio Bizzo, notificou extrajudicialmente a associação dos autores pedindo uma retratação pública, por entender que o documento enviado ao ministério e publicado no site da Abrale ataca sua credibilidade e sua imagem profissional.

O MEC diz que "a avaliação passa por constantes reformulações", que incluem revisão dos critérios, dos procedimentos e também dos representantes da comissão e das coordenações de área e institucional. $\mathrm{O}$ documento assinado por Feres diz ainda que as equipes de avaliadores são formadas por especialistas conceituados e respeitados.

Quanto à possibilidade de réplica por parte de autores em cujos livros foram apontados erros, Feres lembra que a questão já foi objeto de mandado de segurança, ao qual foi dado um parecer dizendo que a avaliação não é um contencioso (disputa), mas um certame (concorrência), portanto, não caberia nenhum recurso. As correções deve ser feitas de uma avaliação para outra, diz o MEC.

Sobre a possibilidade de a avaliação se transformar num processo de certificação contínuo, o ministério sustenta que isso implicaria "desatualizações intransponíveis" para os alunos, "tendo em vista a velocidade com que as informações circulam".

Em resposta à notificação encaminhada por Nélio Bizzo, a Abrale afirmou que não teve intenção de denegrir a imagem dele, mas de mostrar a necessidade de ampliar o diálogo entre autores e avaliadores. Disseram-se dispostos também a publicar a notificação e a resposta da entidade.

A advogada de Bizzo, Beatriz de Abreu Dallari Guerreiro, afirma que uma ação por danos morais é uma alternativa em estudo, caso não julgue suficiente a atitude da Abrale. "Mas só em último caso."

Para Bizzo, os autores que criticam o processo estão "bravos" por terem sido rejeitados e precisarem devolver os direitos autorais antecipados pelas editoras -o que os autores negam. Ele diz que, embora não interfira diretamente no processo, analisa os pareceres da comissão de avaliação e nunca viu problemas que não estivessem bem justificados.

\section{NOTÍCIA 25}

São Paulo, terça-feira, 21 de março de 2006 Folha dE S.PAulo COtidiano

\section{SAIBA MAIS}

\subsection{0 estudantes ainda estão em prédios de latinha}

Segundo a Secretaria Municipal de Educação as escolas que não estão prontas -Emei e Emef Parque das Flores e Emef Jardim das Laranjeiras, na região de São Mateus-, além da Emef Jardim Vila Nova, em Itaquera, serão entregues neste semestre. A secretaria disse que os pais dos alunos pediram que os estudantes só saíssem das escolas de latinha quando os prédios de alvenaria estivessem prontos. 
São Paulo, terça-feira, 21 de março de 2006 FolHa de S.PAulo COtidiano

\section{OUTRO LADO}

\section{"Condições mínimas são atendidas"}

O secretário da Educação da prefeitura, José Aristodemo Pinotti, não comentou ontem a situação dos alunos na escola. A coordenadoria de educação de Itaquera, designada pela secretaria para comentar o problema, afirmou que as condições mínimas para o funcionamento da Emef estão atendidas.

Mesmo sendo de alvenaria, cada classe tem um ventilador. "A escola de latinha era muito pior", disse a coordenadora Elizabete dos Santos Manastarla.

Apesar de declarar que isso seja suficiente, Manastarla afirmou que hoje cada classe ganhará mais uma peça. "Não é porque você [a reportagem] está aqui. Tínhamos pedido isso no último dia 3. A compra já está empenhada", disse -a nota com o empenho (último passo burocrático antes da compra) tinha data de ontem.

Com relação à redução do tempo das aulas, o diretor da escola, Francisco Calado, disse que tomou tal decisão para que os alunos não andassem "no sol a pino". No período da tarde, os alunos costumavam entrar às $13 \mathrm{~h}$ e passaram a entrar às $14 \mathrm{~h}$. "Além disso, como o trajeto da outra escola [de latinha] até aqui é longo, de cerca de $1,2 \mathrm{~km}$, quis dar um tempo para as crianças se adaptarem", disse. "Pensei neles. Não sabia que havia reclamações."

Ele afirmou que o tempo de duração da aula volta ao normal amanhã e que haverá reposição do tempo perdido no período -as aulas começaram no local na metade de fevereiro.

Sobre o forno da padaria, o diretor disse que ele é elétrico e não causa calor excessivo nas salas. "Só fica um cheiro de pão. Talvez isso confunda."

Sobre a falta de área de lazer, a coordenadora disse que a escola poderá usar mais os equipamentos ao seu redor -tanto escolas como CEUs e o Sesc.

A coordenadora disse que a Emef tem saída de emergência, mas que não foi mostrada aos alunos para eles não brincarem no local. "Os professores sabem." Há previsão também de reforma de banheiros no local.

\section{NOTÍCIA 26}

São Paulo, segunda-feira, 05 de março de 2007 FolHa de S.PALlo COtidiano

Nenhuma escola estadual na cidade de SP obteve nota azul

Segundo a diretora da Faculdade de Educação da USP, Sonia Penin, pode-se falar em metodologia, fatores pedagógicos, proximidade da escola de equipamentos culturais, qualificação do professor ou outras tantas variáveis, mas, para ela, o fator mais importante a determinar o fiasco das públicas é o número de horas de estudo. "A exposição do aluno ao estudo e à cultura, consubstanciada na carga horária é o nó mais evidente do ensino público", afirma.

Horários puxados

A desvantagem do estudante da rede estadual cresce mais se considerada a praga do absenteísmo dos professores, um "problema impressionante", segundo Penin.

"Inclusão excludente"

O professor Demerval Saviani, da Faculdade de Educação da Universidade Estadual de Campinas, 
acredita que uma explicação possível para o resultado pífio das estaduais esteja no que chamou de "inclusão excludente", gerada pela "progressão continuada".

"Incluiu-se o aluno na escola, sem dar a ele o domínio de conteúdos elementares. "Segundo Saviani, "houve um esforço para melhorar as estatísticas, e não o ensino".

Ele explica: até 1998, 98\% dos alunos tinham acesso ao ensino fundamental. Mas pouco mais da metade conseguia formar-se na $8^{\text {a }}$ série. No início dos anos 90, cerca de 1,5 milhão de alunos eram expulsos ou fracassavam na escola por ano.

Saviani, que não é contrário à "progressão continuada", diz, porém, que o que se fez "foi tentar resolver o drama da evasão e da repetência com uma canetada, sem dotar a escola de instrumentos para garantir que o aluno com dificuldade pudesse resolver esse atraso, com aulas de reforço, por exemplo".

"Implantada em 1997, o resultado da progressão continuada é o que está aí: alunos saem da $8^{\text {a }}$ série mal sabendo ler e escrever e entram no ensino médio sem condições de acompanhar as aulas por absoluta falta de conhecimentos básicos. Pior do que as notas do Enem despencarem, é ver que a falta de investimento na educação está mantendo a maioria da juventude excluída da atual sociedade do conhecimento", diz.

\section{NOTÍCIA 27}

São Paulo, quarta-feira, 04 de abril de 2007 Folha de S.Pallo COtidiano

\section{MEC exigirá que professor seja avaliado}

As medidas são inspiradas nas práticas pedagógicas de 200 municípios com média superior a 5 no novo indicador do MEC, o Ideb, que leva em conta o desempenho local na Prova Brasil (que avalia a qualidade) e as taxas de aprovação. No que diz respeito aos professores, além de instituir avaliação do desempenho, o decreto vai exigir a implementação de um plano de carreira, cargos e salários, que deve "privilegiar o mérito, a formação e a avaliação do desempenho".

Outro item que reforça a necessidade de "valorizar o mérito" do docente dá como critérios para a avaliação a "dedicação, assiduidade, pontualidade, responsabilidade, realização de projetos e trabalhos especializados, cursos de atualização e desenvolvimento profissional".

Ao apresentar o plano a educadores há duas semanas, o ministro Fernando Haddad disse que teria disponível até R\$ 1 bilhão para investir nos municípios com piores indicadores. Uma equipe técnica também visitaria os municípios.

\section{Apoio}

A proposta de exigir uma avaliação dos professores foi bem aceita por representantes dos docentes e gestores. "Não somos contrários à avaliação. A questão é saber como ela será feita", afirmou o diretor da CNTE (Confederação Nacional dos Trabalhadores em Educação) Denilson Bento da Costa. "O perigo é que não haja critérios claros, e o poder fique nas mãos dos diretores.

Professores podem ser retaliados injustamente."Para a presidente da Undime (entidade que reúne os secretários municipais de Educação), Maria do Pilar, "não há nada mais desestimulador para um professor aplicado ganhar o mesmo que outro desinteressado, que falta a toda hora".

Já a presidente do Consed (conselho que reúne os secretários estaduais), Maria Auxiliadora Seabra Rezende, afirma que o desafio é "criar uma avaliação justa, que não seja punitiva nem meramente cartorial". Ontem, Haddad afirmou que serão contratados 80 técnicos-consultores da Unesco, que serão "um braço do MEC nos municípios com mais dificuldades". De acordo com ele, o Ideb já identificou os mil municípios mais debilitados e os 200 com melhor situação. 


\section{NOTÍCIA 28}

\section{São Paulo, terça-feira, 29 de abril de 2008 FolHa de S.Pallo COtidiano}

\section{Burocracia tira verba das piores escolas}

De 12 escolas consultadas, 10 não receberam ajuda; secretários de Educação pedem flexibilidade ao MEC, que admite problemas

Dez dessas cidades reclamaram da burocracia, que tem dificultado o recebimento dos recursos. Um exemplo é Aquibadã (SE), onde há só uma sala de leitura e uma quadra esportiva para as 27 escolas da cidade. A prefeitura pede verba para melhorar todas as unidades.

Já Dom Aquino (MT) busca verbas para a construção de uma escola, pois parte da rede municipal funciona de forma improvisada em salas que já chegaram a ser interditadas pelo sistema estadual, por serem vizinhas a uma delegacia.

O MEC admite o problema (leia mais nesta pág.), mas diz que nenhum recurso do PDE deixou de ser aplicado.

A Secretaria do Tesouro Nacional diz que as exigências são feitas para evitar que um imóvel, depois da aplicação de verbas da União, seja reclamado pelo proprietário, prejudicando o atendimento à população.

A presidente do Consed (conselho que representa os secretários estaduais de Educação), Maria Auxiliadora Seabra Rezende, diz que o problema burocrático é preocupante.

"Estamos pedindo mais flexibilidade ao governo. Um dos pontos mais críticos para os municípios mais pobres é justamente a construção ou reforma dos equipamentos escolares", afirma a presidente da Undime (entidade que representa os secretários municipais de Educação), Justina Silva.

"A burocracia atrapalha. Faltou uma vírgula, o projeto volta", diz a secretária de Educação de Itaúba (MT), Ivanir Cavalheiro Zonta -cidade com o segundo pior indicador do país.

Apesar das críticas com relação às verbas para infra-estrutura, todos os gestores elogiaram os demais pontos do plano do governo, principalmente o auxílio técnico. "É um problema que temos de resolver, talvez com visita a cada local", diz a secretária de Educação Básica do MEC, Maria do Pilar.

\section{NOTÍCIA 29}

São Paulo, sexta-feira, 20 de março de 2009

\section{Folha des.Pallo Cotidiano}

\section{Piores escolas reduzem aula por falta de água}

Segundo os pais, o problema se arrasta desde 2008, quando o Idesp da escola caiu 47,8\%.

Os pais também se queixam da falta de dedicação de professores. "Transferi minha filha de escola neste ano", diz a dona de casa Francisca Batista. Segundo ela, uma das professoras da filha chegou a escrever carroça com dois "s".

A Folha entrou ontem na escola e viu três banheiros interditados. Na saída, um aluno pediu para usar um deles e uma funcionária disse que não poderia. As salas estavam sujas. Nesta semana, houve uma reunião com pais e a nova diretora. "Vamos ver no que dá agora", diz Luciane Nunes, mãe de uma aluna. A diretora não quis dar entrevista. Na escola Professor Renato de Arruda Penteado, a pior no ensino.

\section{Outro lado}

A Secretaria da Educação admitiu os problemas. Afirmou que a Dr. Genésio de Almeida Moura tem quatro banheiros e que dois estão em reforma e ficarão prontos na próxima semana. Os outros, da direção, podem ser usados pelos alunos. Sobre a Professor Renato de Arruda Penteado, a secretaria afirmou que o problema dos banheiros é a falta d'água na região -informação contestada pelos moradores - e que hoje irá mandar um caminhão-pipa para suprir a escola. Sobre a falta de professores, a secretaria 
afirmou que há docentes, mas que eles faltam e que irá chamar eventuais -que cobrem os ausentes - a partir de segunda-feira.

\section{NOTÍCIA 30}

São Paulo, quinta-feira, 26 de março de 2009 FolHa dE S.PALLo COtidiano

\section{SP pagará bônus a $72 \%$ dos funcionários da educação}

O governo de São Paulo anunciou ontem que pagará uma bonificação salarial para 195,5 mil dos 270 mil servidores da rede estadual de ensino, entre eles 131 mil professores, diretores e supervisores.

Como antecipado ontem pela Folha, a bonificação contemplará também professores e servidores de escolas que já têm bons indicadores de qualidade, mas que, pelo projeto original, ficariam sem essa gratificação porque não conseguiram melhorar o desempenho. Ao lado da secretária da Educação, Maria Helena Guimarães de Castro, o governador José Serra (PSDB) negou, ao divulgar o bônus, ter havido mudança de regras. "Foi uma regulamentação por parte da secretaria, que decidiu, além dos bônus, também dar uma gratificação para as $10 \%$ melhores. Tem escolas que estão no topo dos $10 \%$, então nós resolvemos também dar um prêmio para incentivar que continuem por cima."

"É um modelo que premia o mérito, que premia a evolução de cada escola. Cada escola deve melhorar em relação ao seu ponto de partida, que foi dado em 2007", afirmou a secretária Maria Helena.

O valor menor é criticado pelo presidente da Udemo (sindicato dos diretores das escolas estaduais), Luiz Gonzaga de Oliveira Pinto. Ele diz discordar do critério e que as escolas com índice elevado deveriam ter bônus máximo, pois já realizam um "bom trabalho". Ele afirma ainda que, "enquanto os salários do magistério não forem compatíveis, o bônus será sempre um problema sério, não vai satisfazer a ninguém." 